\title{
Civil service in an emerging democracy: the case of the Maldives
}

\author{
by \\ Mohamed Faizal \\ A thesis submitted to the Victoria University of Wellington in \\ fulfilment of the requirements for the degree of \\ Doctor of Philosophy in Public Policy
}

Victoria University of Wellington

2013 



\section{$\underline{\text { Abstract }}$}

The establishment of a statutory civil service has been an important element of democratisation in the small-island state of the Maldives, an emerging democracy. "Civil service", "democratisation", and "small-island states" are terms discussed widely in the contemporary literature, though not in an integrated manner. By synthesising these terms using relevant literature, in a case study approach with qualitative data, this study primarily aims to analyse the development of a civil service model as part of a process of democratisation in the Maldives. The study also aims to identify how certain features of small-island states could affect both democratisation and the development of a civil service in the Maldives.

The analysis reveals five main findings. Firstly, the development of the civil service model and the negotiation of the civil service Act were part of the democratisation process but were in the hands of political elites and involved no wider public participation. This was consistent with Welzel's model of mass responsive democratisation and Huntington's transplacement model - which proposes that while mass protests and other expressions of opinion are important in triggering democratisation processes, these processes are at some stage moved forward by negotiation or consensus within or between elites.

Secondly, the civil service Act that emerged was a mix of pre-existing codes of practice which had some specifically Maldivian elements but drew on other regional administrative codes, together with borrowings based on research into the current civil service laws of other countries. The result was a law which was founded on some principles commonly described as "Weberian" but adapted to Maldivian circumstances.

Thirdly, the choices that the lawmakers made regarding the civil service model were motivated by a number of different considerations but the dominant agenda was securing a politically neutral civil service largely insulated from the direct patronage of the political executive. This was a result of a wider elite negotiation on the future extent of executive power. Thus, the issue in drafting that turned out to be most important was setting the boundary between the political arm and administrative arm 
of the executive; many detailed provisions that were not relevant to the dominant agenda were carried over from previous Maldivian codes or drawn from the codes of other jurisdictions, in either case with little debate.

Fourthly, the transition to democracy is not complete in the Maldives. The process is still relatively unstable and fragile. In particular, although the civil service is now more firmly founded in law and there is less scope for arbitrary political intervention, there is a continuing contest between the political arm and the administrative arm of the executive over the boundaries between them. This ongoing contest continues to be critical for the prospects of stable democratisation.

Lastly, islandness and smallness did not have a major direct bearing on the process of democratisation in the Maldives, although islandness was to some extent a factor in the design of the constitutional architecture. Furthermore, smallness and social cohesiveness is presently not enough to counter the growing polarisation of society which may constitute a threat to the stability of this fragile emerging democracy. The Maldives being a small-island state did not have a significant impact on the choice of the civil service model. Nonetheless, the social closeness of the small Maldivian society may inhibit the separation of public and private life that is important for institutionalising a professional civil service.

These findings and others in this research add to the body of exemplary knowledge regarding the relationship between the main theoretical concepts of civil service, democratisation, and small-island states, and demonstrate that the framework developed from this scholarship is useful for other case studies embodying similar concepts. 


\section{Preface}

Parts of this study appeared as a book chapter given below. Although I was the main author, Rob Laking revised the paper for substantive intellectual content and shared overall editing of the final draft.

Faizal, M., \& Laking, R. (2013). An independent institution of governance? A new statutory civil service in the Maldives. In I. Jamil, S. Askvik, \& T. N. Dhakal (Eds.), In search of better governance in South Asia and beyond. Springer.

References to the events and processes until March 2012 are mentioned in this thesis.

All translations not otherwise attributed are my own. 


\section{$\underline{\text { Acknowledgements }}$}

This intellectual journey would have been impossible without the support of a number of organisations and individuals. Firstly, my sincere thanks and gratitude are due to the government of New Zealand and NZAID for awarding a generous scholarship that supported me and my family. My appreciation goes to Victoria University of Wellington, especially the School of Government, Victoria International, NZAID team, Library, Student Learning Support Service, Accommodation Service, Early Childhood Services, and Student Finance Services for their efficient support and assistance throughout the period of study.

My study would not have been successful without the generous intellectual and inspirational support of my supervisor Rob Laking. He has been supportive beyond my academic life, including to my family. My heartfelt respect, gratitude, and best wishes are due to him for giving generously his time and knowledge.

I am also thankful to Associate Professor Graham Hassall, Dr. Amanda Wolf, and Adjunct Professor Bob Gregory for their critical comments and suggestions that are the strengths of this thesis.

My thanks are due to all the participants of this study. Without their kind participation and informative input, this research would have remained incomplete. Thank you to Zakariyya Hussain, Ahmed Hassan Didi, and Abdul Raheem Hassan for arranging a number of interviews for me. I am also indebted to all the government organisations, especially the Civil Service Commission that provided me with valuable documents and data that were required for this research. I am also thankful to my parents-in-law who provided the perfect environment for me to transcribe most of my interviews when we visited them during the latter stages of my field research. Thank you also to Ibrahim Uvais for checking my reference list for any errors.

I am grateful for the emotional support I received from my father, Sameer, and mother, Sheereen. Without their love, care, support and encouragement, I would 
have not achieved what I have achieved today. I sincerely dedicate this thesis to them.

Finally, I give my heartfelt thanks to my wife, Hafsa, who gave up her career to accompany me and stood firm through my temperament during this long journey. My love goes to my daughter, Nuha, and son, Hamdhan, both of whom were born during the course of this study. They had to sacrifice so much of the fatherly love they deserve due to my focus on the studies. To them all, my love and gratitude. 



\section{Table of contents}

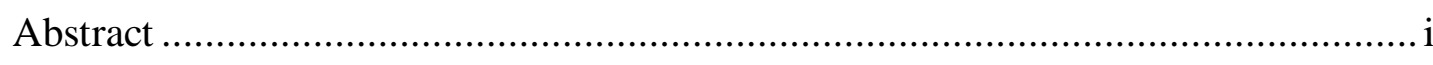

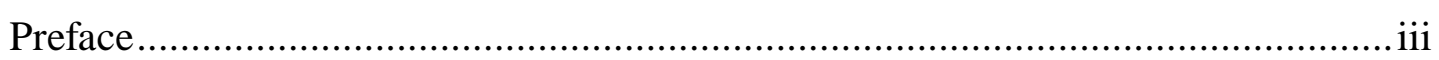

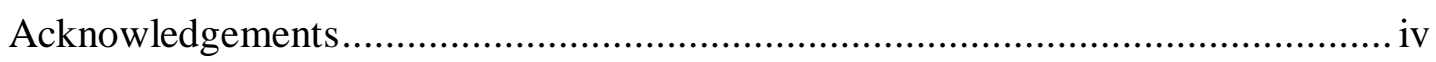

Table of contents....................................................................................... vii

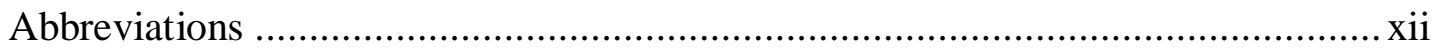

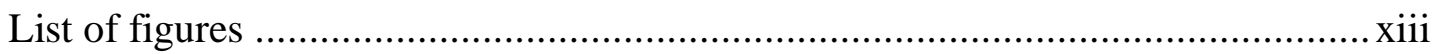

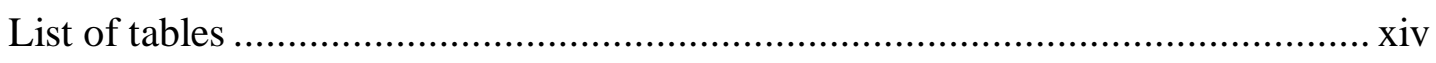

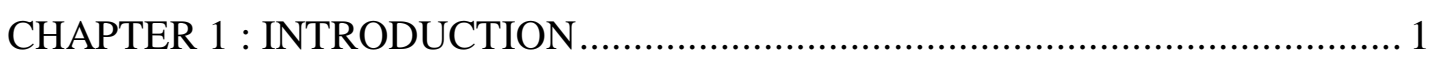

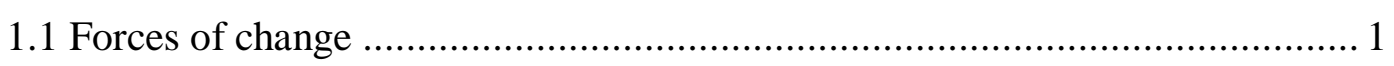

1.2 Research purposes, propositions, and questions ...................................... 2

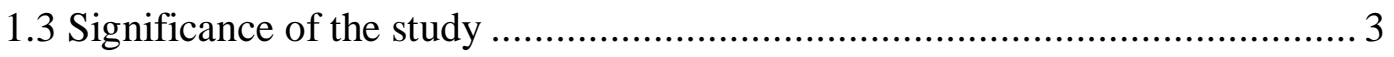

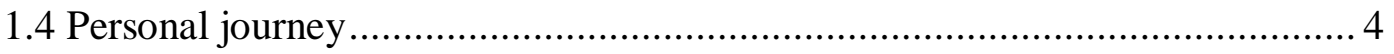

1.5 Definitions of important terms ........................................................... 4

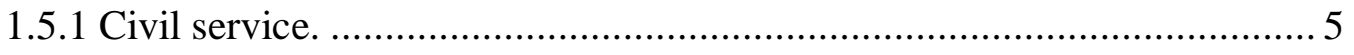

1.5.2 Civil service model...................................................................... 5

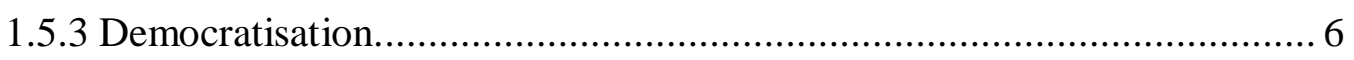

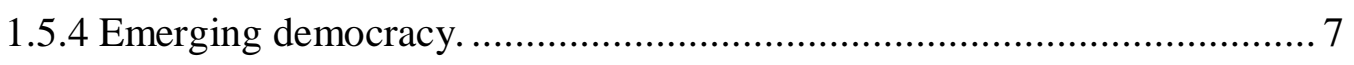

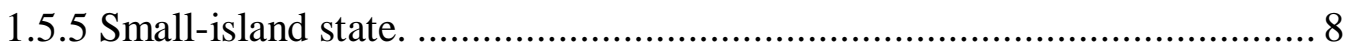

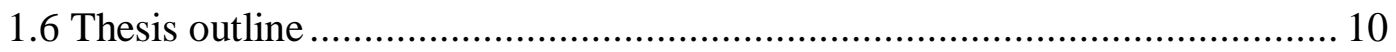

CHAPTER 2 : THEORETICAL FRAMEWORK ….......................................... 12

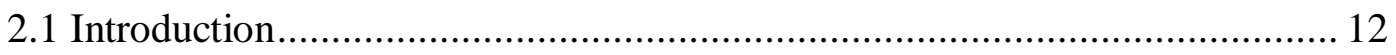

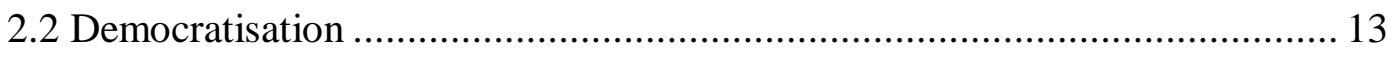

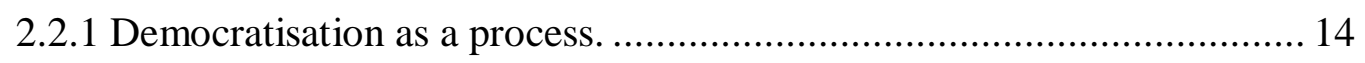

2.2.2 Causes of democratisation. ............................................................. 16

2.2.3 Results of democratisation. ................................................................... 23

2.2.4 Democratisation and small-island states............................................. 28

2.3 Theory of contemporary civil service …................................................. 31

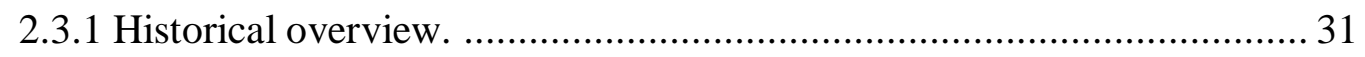

2.3.2 Evolution of civil service models in Europe and the United States. ........ 32

2.3.3 Civil service models in contemporary times........................................ 36

2.3.4 Components of civil service model. ................................................ 40

2.3.5 Legal basis of civil service .......................................................... 43

2.3.6 Scope of civil service..................................................................... 43

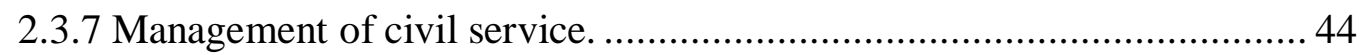




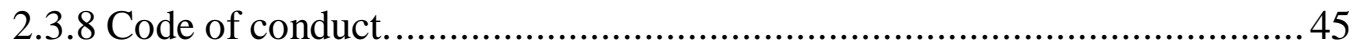

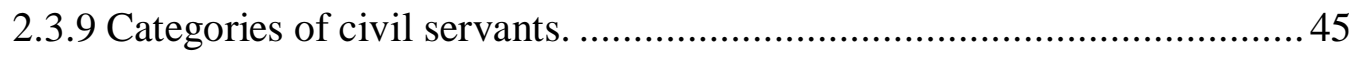

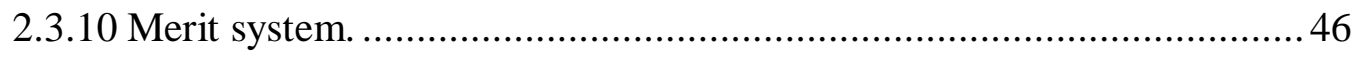

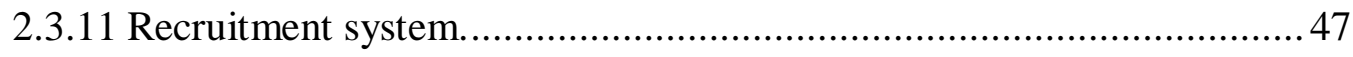

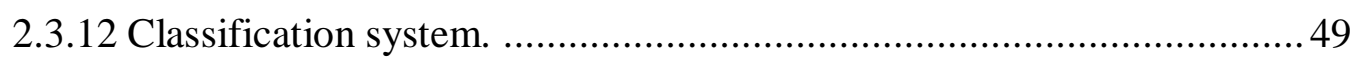

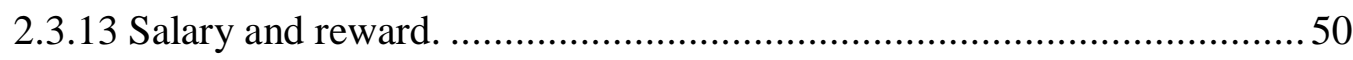

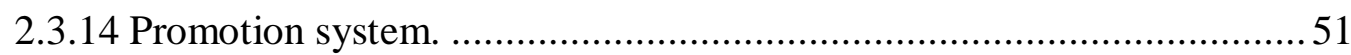

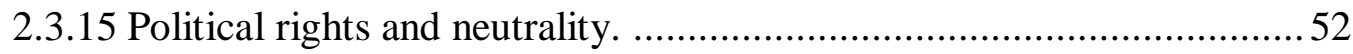

2.3.16 Employment rights and protection............................................... 54

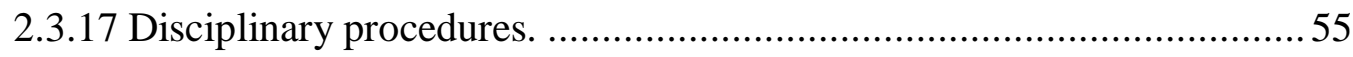

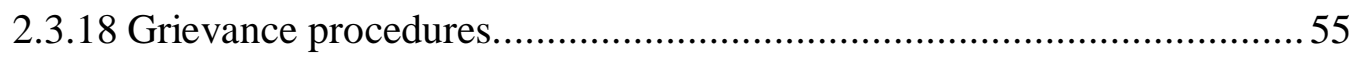

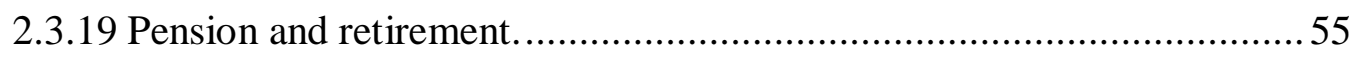

2.4 Linkages between civil service and democracy ........................................56

2.4.1 What is the role of civil servants in a democracy? ................................58

2.4.2 How do politicians influence civil service? .......................................... 61

2.4.3 Are there specific challenges to civil services in emerging democracies?65

2.4.4 What is the role of civil service in national development? .....................67 67

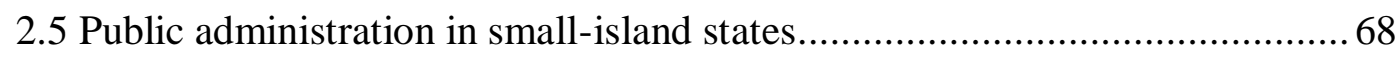

2.6 Policy formulation, decision-making, and political interactions .................. 72

2.7 Conclusion: Implications for the case of the Maldives .............................. 77

CHAPTER 3 : RESEARCH DESIGN AND METHODOLOGY ........................... 80

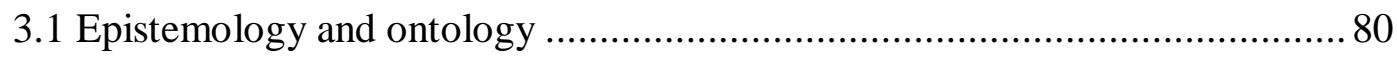

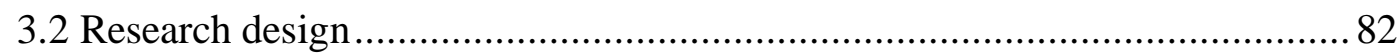

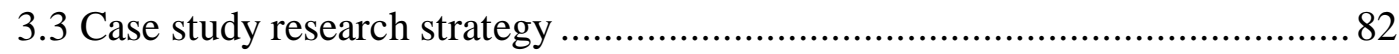

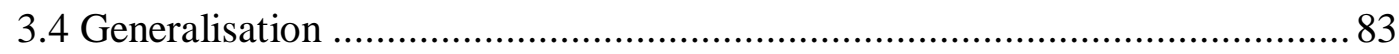

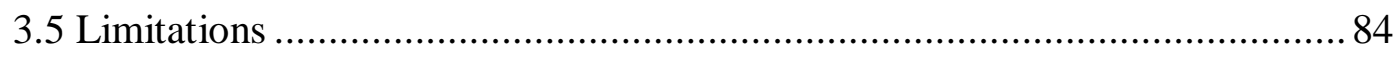

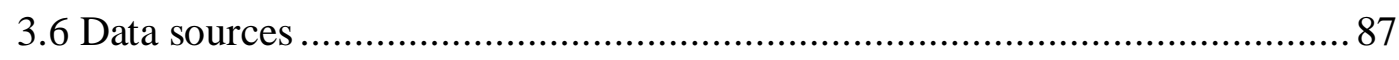

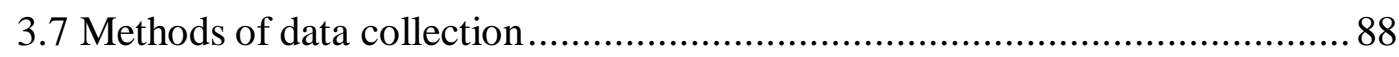

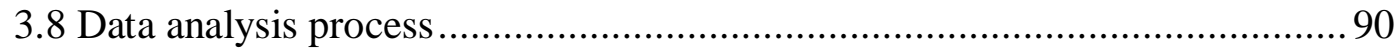

CHAPTER 4 : A NEW DAWN - DEMOCRATISATION IN THE MALDIVES... 92

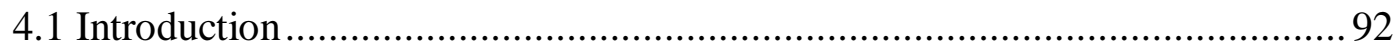

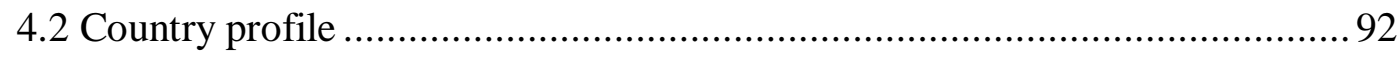

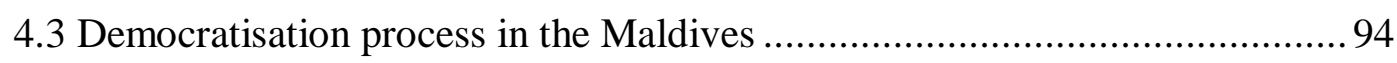

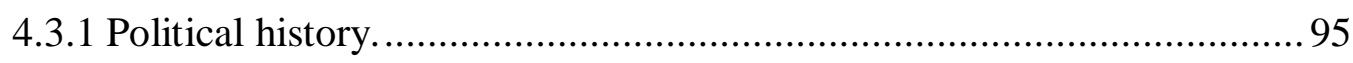

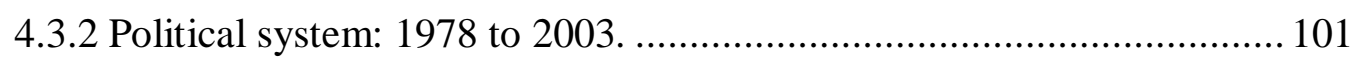

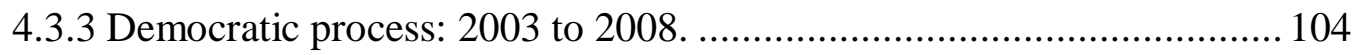

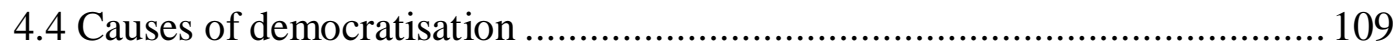


4.4.1 Political elites. 109

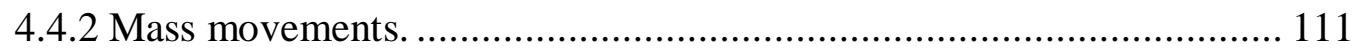

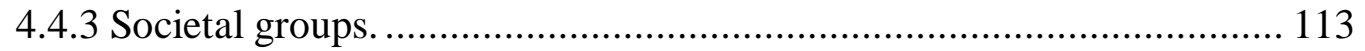

4.4.4 Significant incidents. ................................................................. 113

4.4.5 Economic developments. ........................................................... 114

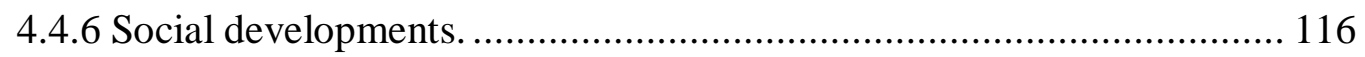

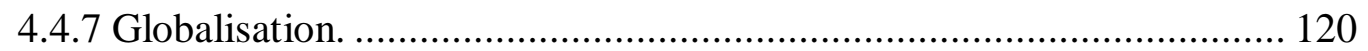

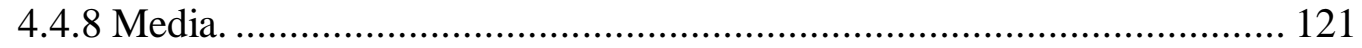

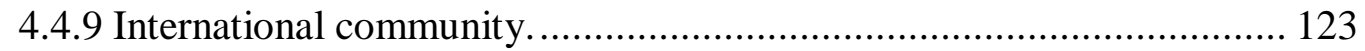

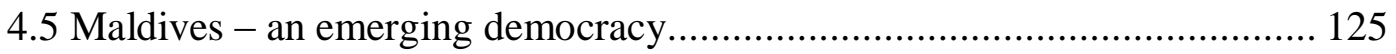

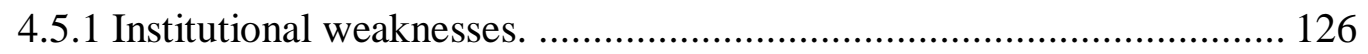

4.5.2 Challenges to free media.......................................................... 132

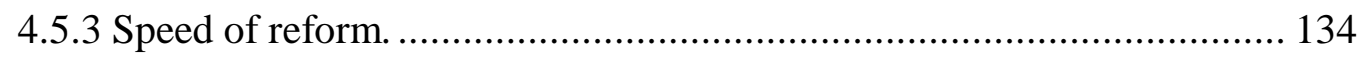

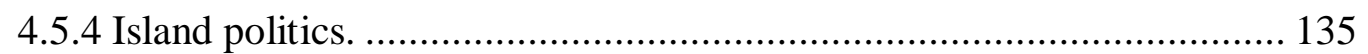

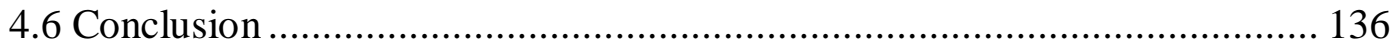

CHAPTER 5 : EN ROUTE TO A STATUTORY CIVIL SERVICE .................... 138

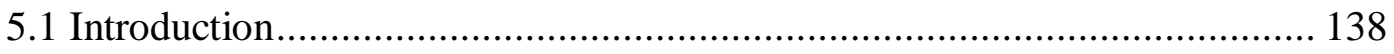

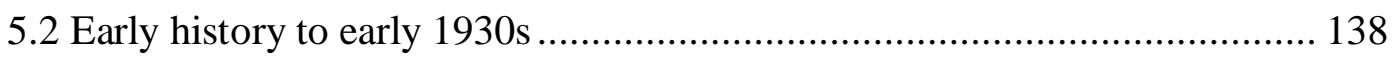

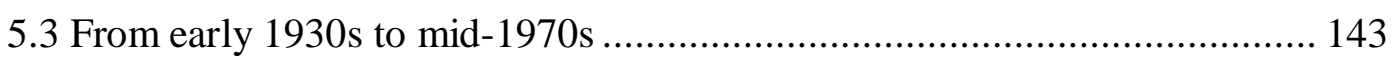

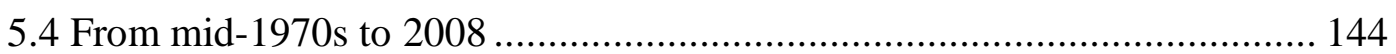

5.4.1 Impact of education and training. .................................................. 144

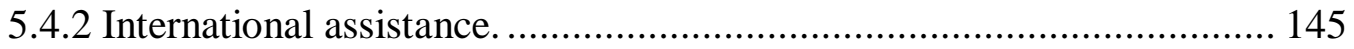

5.4.3 Organisational development. .................................................... 146

5.4.4 Centralisation of administration. .................................................. 148

5.4.5 Inadequate performance management system. ............................... 149

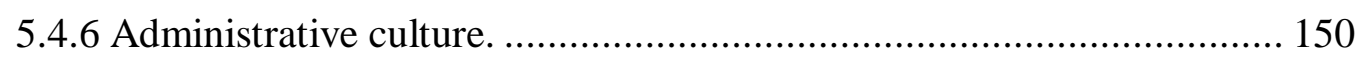

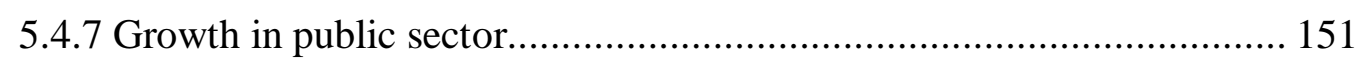

5.4.8 Towards a civil service. ................................................................ 154

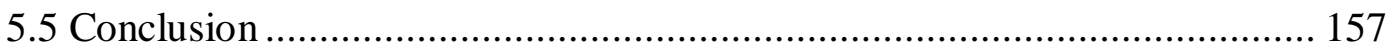

CHAPTER 6 : FORMULATION OF THE CIVIL SERVICE MODEL................ 159

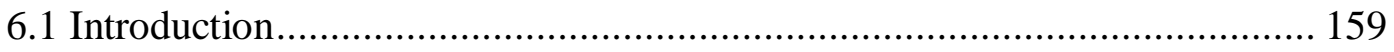

6.2 Submission of a civil service bill ........................................................... 160

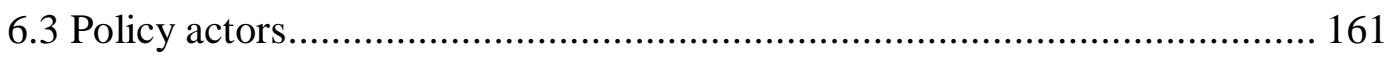

6.4 Amendments to the civil service bill.................................................. 162

6.4.1 Functions of civil service commission. ............................................... 163

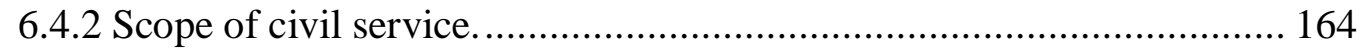

6.4.3 Qualifications and term limits of the civil service commissioners. ....... 167 


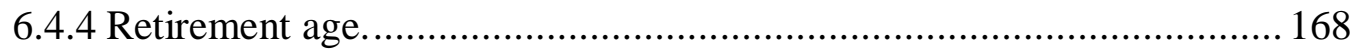

6.4.5 Political participation. .................................................................. 170

6.4.6 Appointment of permanent secretary .................................................. 172

6.4.7 Senior executive service.................................................................. 173

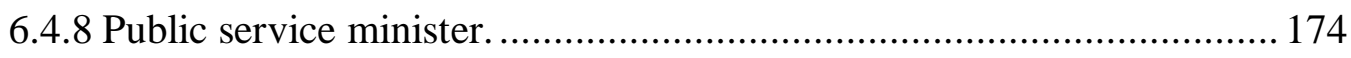

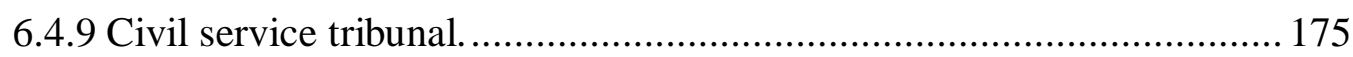

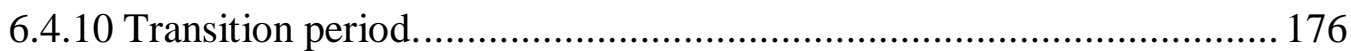

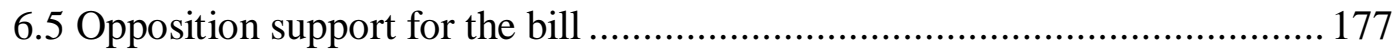

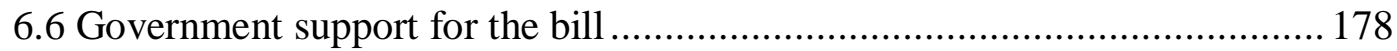

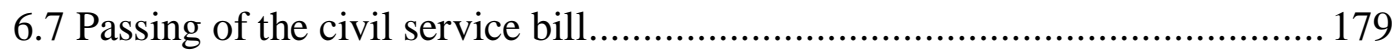

6.8 Civil service model of the Maldives.......................................................... 180

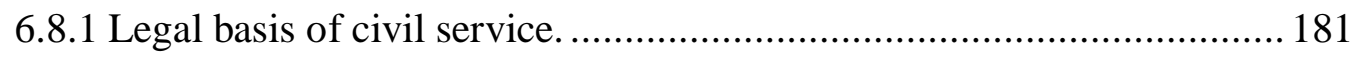

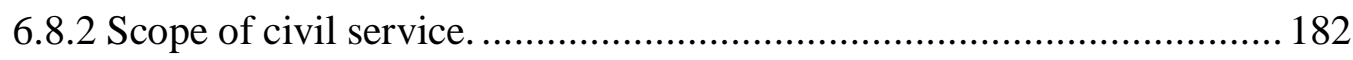

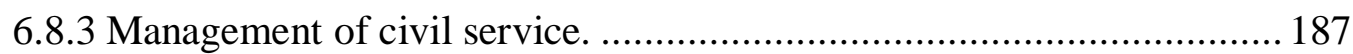

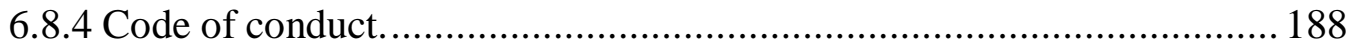

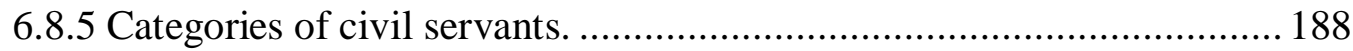

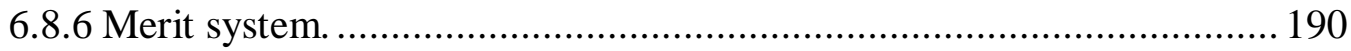

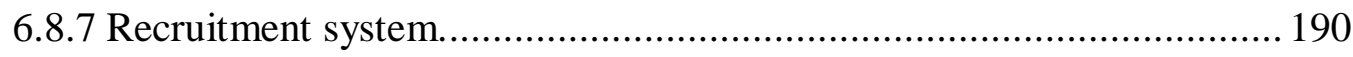

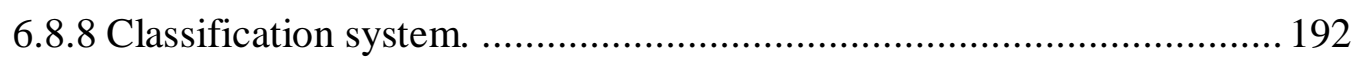

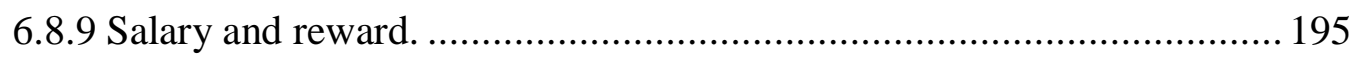

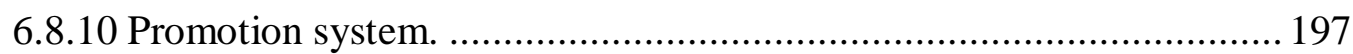

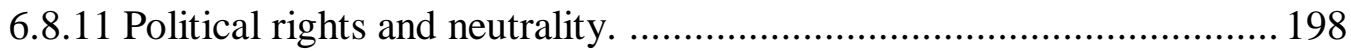

6.8.12 Employment rights and protection...................................................... 200

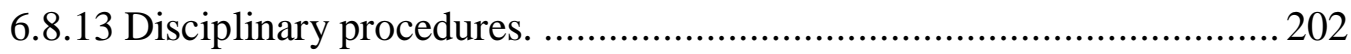

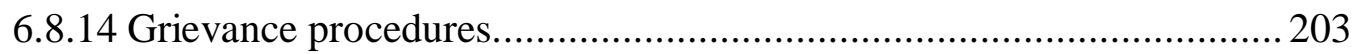

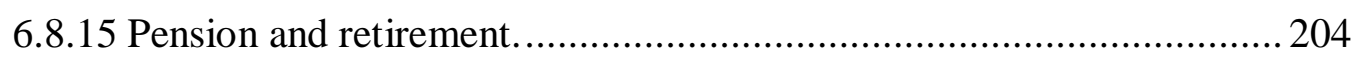

6.9 Overseas influences on the Maldivian civil service model.............................205

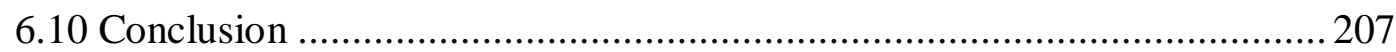

CHAPTER 7 : CIVIL SERVICE IN AN EMERGING DEMOCRACY ..................212

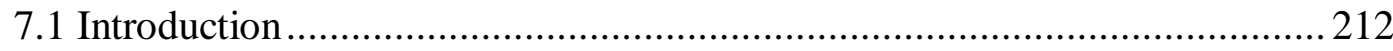

7.2 Impact of civil service model on the democratisation process .......................212

7.2.1 Impact of the independent model. .......................................................213

7.2.2 Impact of the centralised model. .......................................................... 218

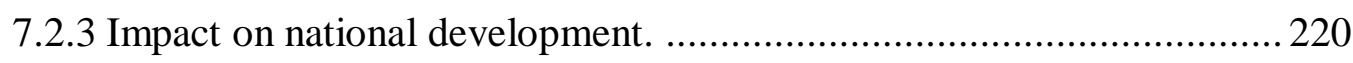

7.3 Impact of democratisation process on the civil service model .......................221

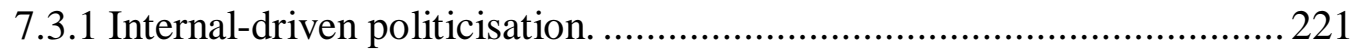

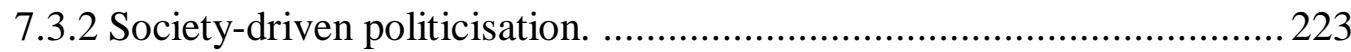


7.3.3 Politician-driven politicisation.

7.4 Civil service in an emerging democracy ........................................... 228

7.4.1 Law-oriented approach of the civil service........................................ 229

7.4.2 De-institutionalisation of the civil service......................................... 231

7.4.3 Frequent amendments to the Civil Service Act................................ 238

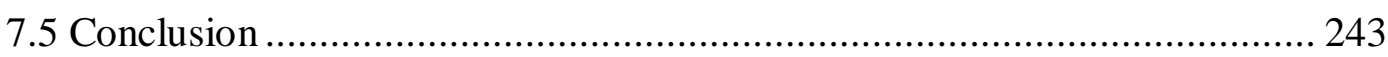

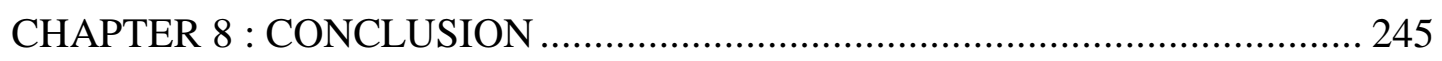

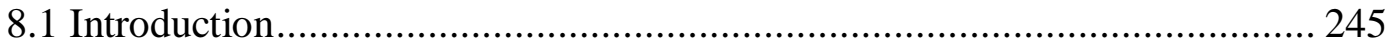

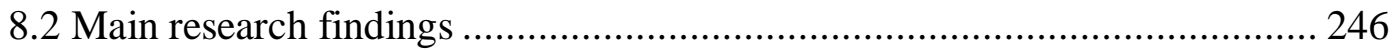

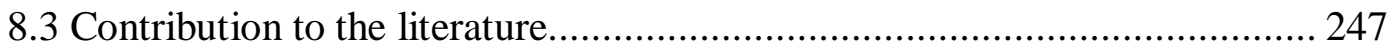

8.4 Lessons for the Maldivian civil service .................................................. 248

8.5 Implications for future research ....................................................... 250

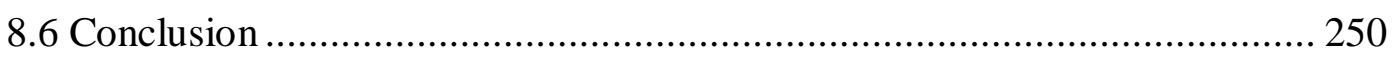

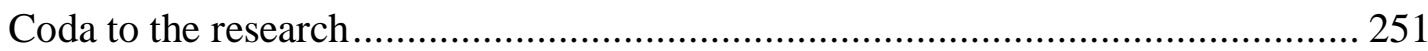

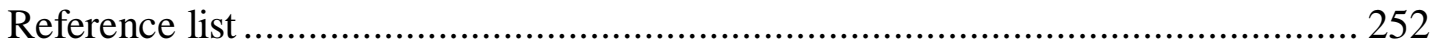

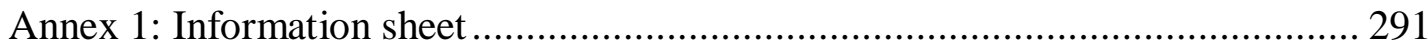

Annex 2: Consent to participation in research ............................................... 293

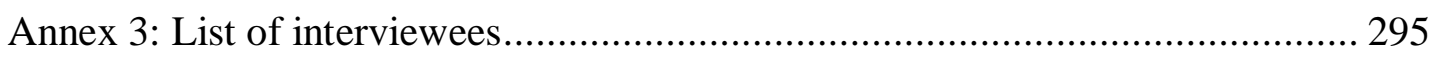

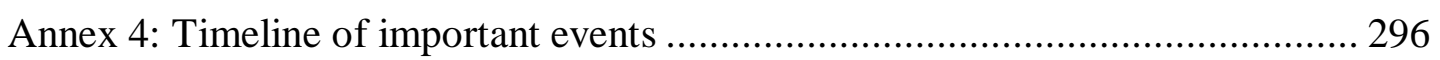

Annex 5: Government organisation chart - July 1979 .................................... 297 


\section{$\underline{\text { Abbreviations }}$}

ADB Asian Development Bank

CEE Central and Eastern Europe

CoE The Committee of Minister of Council of Europe

CS Civil Service

CSC Civil Service Commission

CSO Civil Society Organisation

DIB Department of Information and Broadcasting

DNP Department of National Planning

DRP Dhivehi Rayyithunge Party

EU European Union

GDP Gross Domestic Product

IFJ International Federation of Journalists

JSC Judicial Service Commission

MBC Maldives Broadcasting Corporation

MCSR Maldives Civil Service Regulation

MDP Maldivian Democratic Party

MOFT Ministry of Finance and Treasury

MP Parliament Member

MPND Ministry of Planning and National Development

MVR Maldivian Rufiyaa

NOPAR National Office of Personnel and Administrative Reform

ODA Official Development Assistance

OECD Organisation for Economic Co-operation and Development

PO President's Office

PS Permanent Secretary

PSD Public Service Division

SES Senior Executive Service

SOE State Owned Enterprise

UNDP United Nations Development Programme

WB World Bank 


\section{List of figures}

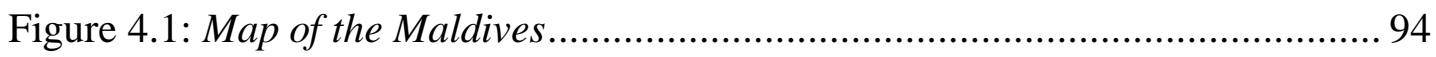

Figure 4.2: Government overseas scholarships awarded (1995-2008) ................. 118

Figure 4.3: Population pyramid 1985 ................................................................... 119

Figure 4.4: Population pyramid 2006............................................................... 119

Figure 5.1: Administrative setup of the Maldives (1980) ...................................... 147

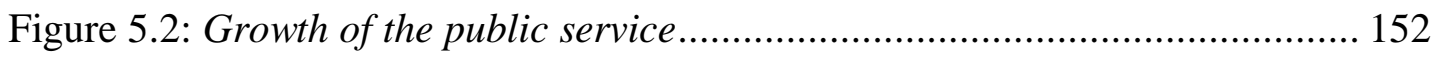

Figure 6.1: Civil servants versus staff moved out of civil service (2008-2011) ...... 185

Figure 6.2: Administrative structure of designations.......................................... 193

Figure 6.3: Completion of performance appraisal forms ................................... 194

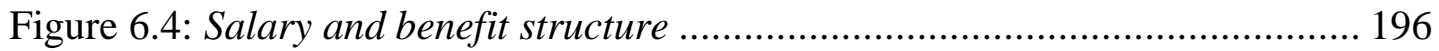

Figure 7.1: Civil servants working in Male' and atolls ..................................... 234 


\section{List of tables}

Table 2.1: Typical elements of a classical career model and model with other structural characteristics................................................................... 41

Table 2.2: Incentives for civil servants.......................................................... 51

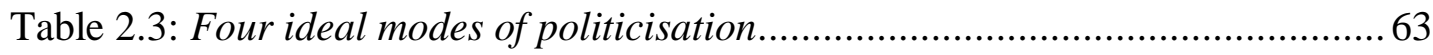

Table 4.1: Registered population in inhabited islands as of December 2009........... 93

Table 4.2: Comparison of main components of 1968 and 1998 constitutions ........ 101

Table 4.3: Comparison of main components of 1998 and 2008 constitutions ........ 107

Table 4.4: Trends in economic development ...................................................... 115

Table 4.5: Fellowships awarded by the World Bank training projects................... 117

Table 4.6: International aircraft movement at Male' International Airport (19852005)

Table 4.7: Net official development assistance received by small-island states as percentage of GNI

Table 4.8: International grants for development projects for the Maldives (20022008).

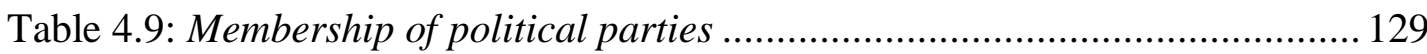

Table 4.10: Parliament composition ................................................................. 130

Table 4.11: Bills submitted and passed in the majlis ............................................ 135

Table 6.1: Functions of the Civil Service Commission .......................................... 164

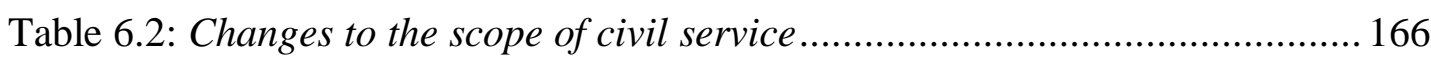

Table 6.3: Changes to the qualifications and term limits of commissioners........... 168

Table 6.4: Retirement age................................................................................ 170

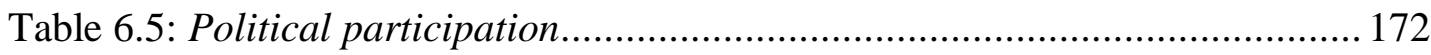

Table 6.6: Appointment of permanent secretary ............................................... 173

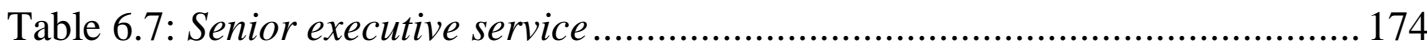

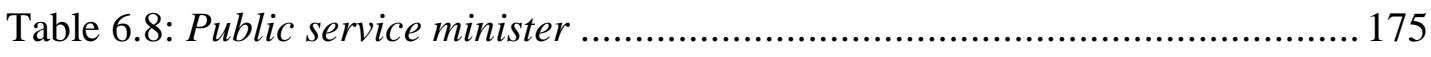

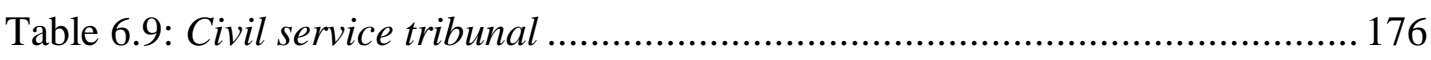

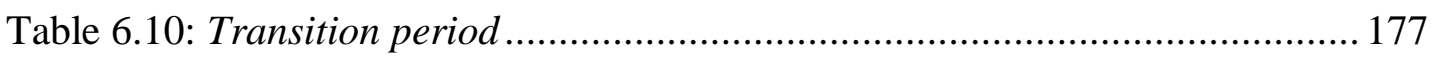

Table 6.11: Organisations included in the civil service ...................................... 183

Table 6.12: Organisations excluded from the civil service .................................. 184 
Table 6.13: Total number of transfer applications approved by the civil service commission

Table 6.14: Total number of appointment applications approved by the civil service commission 192

Table 6.15: Civil servants and their ranks at the end of 2010 195

Table 6.16: Pay scale 197

Table 6.17: Cases submitted to employment tribunal and the courts 204

Table 6.18: Correspondence of OECD objectives to the Civil Service Act 207

Table 6.19: The civil service model of the Maldives............................................. 208

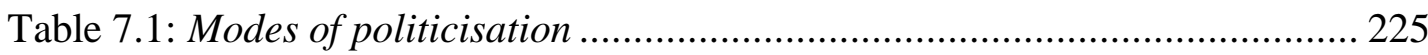

Table 7.2: Comparison of highest ranked political appointments ........................ 227

Table 7.3: Organisations removed from civil service through legislation ............. 232

Table 7.4: Organisations removed from civil service through corporatisation ...... 233

Table 7.5: Total salary comparison between civil service and selected other organisations 



\section{CHAPTER 1: INTRODUCTION}

\subsection{Forces of change}

The emergence of democracy in a nation can take different paths. In some instances, dramatic action may be necessary to trigger the forces that bring change. Although mass mobilisation is neither necessary nor sufficient for regime change, events from the recent past have shown that transitions to democracy from authoritarian regimes have often occurred when mass mobilisations of outraged citizens have demanded changes to their regimes (Huntington, 1991-2, pp. 604-5). Examples of such transition were evident in Eastern Europe during the fall of communism, with Tunisia and Egypt being more recent examples. In most such cases, democratic transition has been rapid rather than gradual. In the case of the Maldives, the last decade has been unprecedented in terms of political awareness developing among the general public. The effects of globalisation, as well as consistent economic growth and social development, have raised the expectations of citizens to the extent that they started demanding more political freedom and a greater say in the running of the country. Civil unrest during September 2003 and a public protest during August 2004 ignited the rapid progress made en route to democratisation. The changes that the nation has witnessed and is still witnessing have been extraordinary. First and foremost, after a 30-year rule by a sole ruler, democratic transition occurred peacefully in 2008, mainly due to a new constitution that provided citizens with rights they had never had before. These changes have transformed the political spectrum in the whole nation.

Governance reform introduced in the Maldives included introducing multi-party politics, electoral reform, judicial reform, liberalisation of media, and strengthening key institutions (refer to section 4.3.3). Reform of the civil service (CS) was also part of this agenda. The main focus of CS reform was on significantly reducing the power of the political executive to control public sector employment by defining a CS and establishing a statutory civil service commission (CSC) provided for in the constitution and empowered by a CS Act, to be responsible for employment of civil servants. This redefinition of the political executive from the CS has so far not been without hiccups and bumps. Nonetheless, the processes involved in the formulation 
of a CS model that is aligned with Maldivian administrative history and the country's on-going political reforms are of significant importance, especially in the context of a small-island state where such drastic changes had been few and far between.

\subsection{Research purposes, propositions, and questions}

The primary purpose of this study is to analyse a case of the development of a civil service model as part of a process of democratisation in the Maldives. The approach used to achieve this purpose is to examine two general propositions for their application in the Maldivian case.

Proposition 1: A period of accelerated democratisation, such as that occurred in the Maldives in the period from 2003 onwards, would be associated with a deliberate programme of institutional change. Civil service reform would be part of this programme and a principal objective of CS reform would be to change the relationship between political and administrative power in the executive.

Based on this proposition, the primary research question is:

\section{What effects has the current model of CS had on the democratisation process and vice versa?}

In order to answer this primary question, this thesis intends to:

1. Describe the CS model of the Maldives in relation to the options available for its development;

2. Analyse the process by which the political actors in the Maldives arrived at the current model of CS during the transition to a multi-party democracy and the reasons for the choices they made; and

3. Analyse the interaction between the political executive and the CS in the context of developing new democratic institutions in the Maldives. 
Proposition 2: Certain features of small-island states like the Maldives, such as the relative social closeness of its citizens and their geographical insularity, would affect both democratisation and the development of a CS.

Based on this proposition, the secondary research question is:

\section{How was the process of democratisation and choice of the CS model different because the Maldives was a small-island state?}

In order to answer this secondary question, this thesis intends to:

1. Describe features of the Maldivian economy and society that seems specific to relatively small and isolated countries;

2. Consider how these features may have specifically influenced the democratisation process and decisions on the choice of the CS model in the Maldives.

\subsection{Significance of the study}

The Maldives is an island nation which, due to its insularity and strategic insignificance, has been sheltered for much of its existence from major outside influences. Although recent and relatively rapid exposure to the effects of globalisation has brought modernising influences, there has also been considerable local pressure to rapidly modernise the Maldives' political institutions to put them on a par with those found in advanced democracies. This pressure is having an impact on a society that has been homogeneous in terms of race, religion, and language. The CS has traditionally been the single biggest employer in the country and the democratisation process is continually altering the functioning of government machinery.

"Civil service", "democratisation", and "small-island states" are terms discussed widely in the contemporary literature, though not in an integrated manner. That is the gap that this thesis attempts to fill by providing a synthesis of these terms from relevant literature. By forming a case around these concepts, this thesis attempts to 
demonstrate that other studies can benefit as knowledge is communicated through concepts that scholars are familiar with and find useful in the study of the formation of public institutions such as the CS, and consequently the relationships between that institution and other institutions in an emerging democracy of a small-island state in particular. In developing a case, this study is testing that proposition in references to previous scholarship. Although there are plenty of general studies of the role of CS in democratic institutions, there are a much smaller number of studies on exactly how CS reform fits in the modern process of democratisation. The Maldives case is an opportunity to study the process where the motivation of elites and the ideas they draw upon in negotiation lead to the formal development of a governance institution.

\subsection{Personal journey}

The reason I undertook this study has primarily been my close involvement in the modernisation and reform of the Maldivian public sector. In my short professional career, I have worked primarily at the President's Office (PO) which I joined after completing high school. Over the years, the experiences that I have accumulated and the opportunities that $\mathrm{I}$ have received to pursue tertiary education in public administration, have furthered my interest in the area of administrative reform and modernisation. In this regard, I have been fortunate to be involved in numerous projects aimed at the modernisation of the public sector, including being a participant in some of the events described in this thesis. I cannot escape the possibility of bias in the choice of evidence, but I have managed the risk as best as I can (refer to section 3.5). The desire to contribute in a scholarly manner to the institutionalisation of a professional CS has always been the driving force for me during this doctoral journey.

\subsection{Definitions of important terms}

Before proceeding, it is imperative to provide at least a partial definition of some of the important terms used in the study. The task is undertaken with the recognition that universally accepted definitions for these terms probably do not exist. Nonetheless, it is important to appreciate their meaning in the context of this research. The following provides the meanings given to the terms in this study. 


\subsubsection{Civil service.}

Civil service can mean different things in different situations. Finlay (1966, p. 7) suggests that devising a precise definition for the term informatively and in a legally acceptable manner is not possible. Some authors have nonetheless attempted to do so. Parris $(1969$, p. 22$)$ refers to the civil service as "a body of full-time, salaried officers, systematically recruited, with clear lines of authority, and uniform rules on such questions as superannuation". The Tomlin Commission Report (1931) defines "civil servants" as "those servants of the Crown, other than holders of political or judicial offices, who are employed in a civil capacity and whose remuneration is paid wholly and directly out of monies voted by Parliament" (cited in Jordan, 1994, p. 29). There are numerous other definitions of the civil service (see Dimock \& Dimock, 1969, p. 179; Henry, 2010, p. 210; Starling, 1993, p. 450). However, for the purpose of this research, a civil service will be considered as an organised body of employees of the state subject to a uniform code of employment, directly subordinated to the political executive and governed by the rule of law. Such a synthesised definition aligns with the contemporary forms of government and the functions bestowed upon the CS in such environments.

\subsubsection{Civil service model.}

The CS has been part of the daily vocabulary of public affairs for over a century now, perhaps even longer. ${ }^{1}$ Since the nineteenth century, most nations that have endeavoured to develop a CS have chosen the path of relevant legislation that outlines the scope, parameters, values, and responsibilities of the CS. The role and shape of civil services have been changing over several decades (see Butler, 1993). Furthermore, as a comparative study by Choi and Whitford (2011) shows, differences are evident in how countries shape their CS laws, arguably because how each nation shapes its CS depends on its history as well as lessons obtained from other countries.

\footnotetext{
${ }^{1}$ See section 2.3.1 for a historical overview of the CS.
} 
"Civil service model" and "civil service system" will be used interchangeably in this research. According to Morgan and Perry (1988, pp. 85-6), a CS system refers to "the mediating institution authorized by constitutional rules which mobilizes human resources in the service of the civil affairs of the state in a given territory". Here the CS is seen in functional terms linking the policy formulation and implementation processes by providing the human resources to implement public policy (Burns, 1994, p. 8). Any nation with "institutions that turns [sic] inputs from the environment into outputs such as policy, goods and services for and on behalf of the State may be said to have a 'civil service system"” (Burns \& Bowornwathana, 2001, p. 3).

For the purpose of this research, civil service model means the framework used to define and shape a CS. The term "model", whether or not it is universally accepted, is always a simplified representation of reality in which the major relationships are identified between the stylised component elements. The terms model and system define elements and relationships that are important for this research which will be conducted in large measure through these abstractions. The justification for the use of this approach is that it fits the evidence collected for the research, in the sense that most of the evidence collected assumes similar definitions and relationships.

\subsubsection{Democratisation.}

There is a lack of consensus on the exact meaning of "democracy" (see Beetham, 1994). For the purpose of this research, the term democracy, or what Robert Dahl (1971) terms "polyarchy", will be defined as a political system that meets three minimum conditions:

1. Meaningful and extensive competition among individuals and organized groups (especially political parties) for the major positions of government power;

2. A "highly inclusive" level of political participation in the selection of leaders and policies, at least through regular and fair elections, such that no major (adult) social group is excluded; and 
3. A level of civil and political liberties - freedom of expression, freedom of the press, freedom to form and join organizations - sufficient to ensure the integrity of political competition and participation. (cited in Diamond, Lipset, \& Linz, 1987, p. 5)

With the above minimum pre-conditions required for a nation to be considered democratic, "democratisation" is the process by which a nation transits from a political system that does not encompass those conditions towards a political system that does. In other words, the term democratisation "refers to political changes moving in a democratic direction" (Potter, 1997, p. 3). A movement towards democracy is also most commonly seen as a movement away from autocracy, so that the most significant dimension of democratisation is a limiting of the scope and arbitrary use of executive power. With time being the key factor, the changes during the process occur:

from less accountable to more accountable government, from less competitive (or non-existent) elections to freer and fairer competitive elections, from severely restricted to better protected civil and political rights, from weak (or non-existent) autonomous associations in civil society to more autonomous and more numerous associations. (Potter, 1997, p. 6)

\subsubsection{Emerging democracy.}

There is plenty of evidence from historical accounts of the democratisation process that it does not follow a single path of linked phases. Transition from authoritarian rule to a democratic form of government through fair and free elections marks the beginning of the democratic process. Any state that has embraced the principles of democracy and is moving towards the consolidation of democratic values could be regarded as an emerging democracy. Sørensen (1998, p. 39) points out however, that several phases of "democratic deepening" may be necessary before a democracy becomes mature. Consolidation is reached when democracy is embraced as the "only game in town" (Di Palma, 1990, p. 113) by the major political actors, interest groups, and organisations, and democracy subsequently becomes ingrained in the political culture. Considering the different phases of democratisation evident in 
individual nations, consolidation often takes several decades. This does not imply that reverting back to autocratic rule is not a possibility. Episodic breaches of democratic procedures that challenge the foundation of democracy may be evident. There have also been many reversals and interruptions in the historical record of different countries.

\subsubsection{Small-island state.}

The case chosen for this study is based on a small-island state. Thus a definition of small-island states is needed as it foreshadows later discussion of the effects of smallness and islandness on the nature of society and politics. The aim is to find a group of countries that are broadly in the same range of population size and degree of geographical isolation as the Maldives, for which there are observations that might be relevant to the Maldives. Furthermore, a definition will have more value for reflections from this case study to states that share similar attributes.

In analytical writing one of the major difficulties frequently encountered is when one tries to define terms which are part of everyday language. This is certainly evident when one attempts to define small-island states. For a start, there is no consensus on what is "small" (Eckaus, 1997) or "state" (J. Richards, 1990) or even an "island" (Dommen, 1980). Defining the word small as a measure of country size is problematic as Ott (2000, p. 14) points out, "the question of what constitutes smallness remains unanswered" even after decades of discussion regarding the topic. For those who have used one dimensional measures, state size has been measured, for instance, by using population (Clarke \& Payne, 1987, p. xvii; Harden, 1985); gross national product (GNP) per capita (Robinson, 1960); a combination of population, land area, and gross domestic product (GDP) (Shand, 1980; Crowards, 2002); or power in terms of a country's influence in the international system (Fox, 1959). Others have used multiple measures combined in proportions which can only be considered arbitrary (Vital, 1967). Alternatively, others have used multidimensional measures of viability (Benedict, 1967), capacity for autonomous state action (Emmanuel, 1976), and degree of vulnerability (Commonwealth Secretariat, 1985). As a result definitional efforts with respect to small-size states provide no universal agreement (Khan, 1982, p. 57). 
The attempts at definition are further complicated by the use of terms "small states" (Baker, 1992; Gayle, 1986), "very small states" (United Nations Institute for Training and Research [UNITAR], 1969), or "micro states" (Anckar, 2002; Caldwell, Harrison, \& Quiggin, 1980; Dommen, 1985; Murray, 1981; J. Richards, 1990). Even with differing measures of smallness, defining it without the use of specific indicators presents clear problems. Thus, most researchers have used specific indicators, with "small population" being the most common (J. B. Raadschelders, 1992, p. 27).

As pointed previously, defining island also appears problematic. Glassner (1990, p. 47) states that in simple terms island is "a piece of land surrounded by water". However, Baldacchino (2007, p. 4) cautioned that "the mere rendition of an island as a piece of land surrounded by water is academically imprecise" because, as 70 per cent of the earth's surface is surrounded by water, even a great land mass such as Australia could be termed as an island at the largest scale (Cosgrove, 2007). Furthermore, concerning the concept of "island state", Anckar (1996, p. 702) defines it as "states that are islands or parts of an island or consist of islands and parts of islands".

According to Newitt (1992, p. 16):

not all small states are islands and not all island states are small but the problem of 'smallness' is given an added dimension in the case of an island, and insular isolation can be considerably intensified if you are also small.

Given the lack of unanimity, a specific definition is still needed in order to proceed with this research. As a result, for the purposes of this research, a small-island state is defined as an independent country that has a population equal to or less than one and a half million and is surrounded by sea. This one-dimensional categorisation of the countries is adopted purely for the purpose of simplicity. Based on this definition, as of June 2011, there were 30 small-island states (see table 4.7). 


\subsection{Thesis outline}

Chapter One presents the research purposes, propositions, and questions. It outlines the significance of the research and why the topic was chosen. Brief definitions of the main terms used in the study are also presented. The chapter concludes by outlining the thesis structure.

Chapter Two presents the theoretical framework by providing a synthesis of the terms of the thesis. It is divided into five main sections: (1) the democratisation process; (2) the theory of contemporary civil service; (3) linkages between civil service and democracy; (4) overview of possible features of public administration in small-island states; and (5) processes of policy formulation, decision-making, and political interactions. The chapter concludes by presenting the implications of the literature for the Maldivian case.

Chapter Three presents the research design and methodological approach for the thesis. Firstly the chapter examines epistemology and ontology aspects. It is followed by discussion and justification for choosing a qualitative research design and a case study strategy. The rest of the chapter discusses generalisation, limitations of the study, data sources, methods of data collection, and data analysis.

Chapter Four begins with a brief overview of the Maldives, after which the chapter is divided into three main parts. The first part describes the democratisation process in the Maldives. The next part shows the main causes behind the democratic reforms. The final part argues that Maldives is an emerging democracy and presents the main challenges evident in the effort to sustain and consolidate the democratic transition.

Chapter Five provides a brief history of public administration in the Maldives prior to the establishment of a statutory CS. It argues that the nation went through three major phases that eventually led to a law governing the CS. The first period extended from early historical times to the 1930s when the first written constitution was proclaimed. The second period from the 1930s to the mid-1970s was a period of relative stability in administration due to the greater focus on recovery from the 
effects of World War II. The final stage, from the 1970s to 2008, was a period of relatively rapid economic growth and expanding contacts through travel and communications with the outside world.

Chapter Six focuses on the formulation of a civil service model for the Maldives. It presents the different stages in the formulation of the CS Act as well as the CS model chosen in the Maldives. It examines the actors involved, the germane changes made to the bill, and the rationale behind the support for the bill. The bulk of the chapter examines the attributes of the CS model chosen for the Maldives. A brief glance at the possible influences from overseas CS systems on the Maldives is also undertaken.

Chapter Seven presents the linkages between civil service and democratisation. The prime argument in this chapter is that the CS model chosen for the Maldives has a significant bearing on the democratic process and that, in turn, the democratic process, due to its nascent stage, hinders efforts to institutionalise a professional CS. After examining the impact that these processes have had on one another, the chapter presents a number of features of the CS in the Maldives in the context of an emerging democracy.

Chapter Eight concludes the thesis by presenting the main research findings, contribution to the literature, lessons for the Maldivian CS, and implications for future research. 


\section{CHAPTER 2: THEORETICAL FRAMEWORK}

\subsection{Introduction}

The CS is a significant institution in any democratic society. Countries that have had a long history of an independent CS will bear witness to the validity of this statement. However, establishing and institutionalising an autonomous CS in an emerging democracy can pose a number of challenges. It can be further complicated when both these processes go ahead simultaneously in the context of a small-island state.

There are a number of theoretical frameworks that contribute towards understanding the research questions of this study (see section 1.2). "Civil service", and "democratisation", along with "small-island states" are terms with many connotations attached to them (see section 1.5). Though these concepts are discussed widely in the contemporary literature, they have not been presented in an integrated manner. That is the gap that this thesis attempts to fill. This chapter provides a synthesis of these concepts from relevant literature. The review of literature presented in this chapter aims to show three main arguments that are examined in the context of the Maldives in the remaining chapters of the thesis. Those arguments are:

1. The historical development of the nation is an important factor in democratic transition and consolidation;

2. Civil service reform will be based both on a country's existing institutions and on models from other jurisdictions; and

3. The dynamics between the political executive and the CS are significant factors for institutionalisation ${ }^{2}$ of a professional ${ }^{3} \mathrm{CS}$.

\footnotetext{
${ }^{2}$ According to Selznick (1957, p. 16) "Institutionalization is a process. It is something that happens to an organization over time, reflecting the organization's own distinctive history, the people who have been in it, the groups it embodies and the vested interests they have created, and the way it has adapted to its environment". Selznick (1957, p. 17) goes on to state that "to institutionalize is to infuse with value beyond the technical requirements of the task at hand". In this research, institutionalisation implies being deeply embedded into thought and behaviour.

${ }^{3}$ Cheetham and Chivers (2005, p. xii) define profession as "an occupation based upon specialised study, training or experience, the purpose of which is to apply skilled service or advice to others, or to provide technical, managerial or administrative services to, or within, organisations in return for a fee or salary". There are numerous other definitions of profession (see Carr-Saunders \& Wilson, 1933/1964, p. 287; Freidson, 1994, p. 10; Larson, 1990, p. 30). The professional is the individual who occupies the profession. For the purpose of this research, a professional CS implies "competent,
} 
This chapter is divided into five main sections. The first section focuses on the democratisation of nation states. The second section focuses on the theory of contemporary CS. The third section links the CS and democracy. That is followed by a section discussing attributes of public administration that are common in smallisland states. The fifth section examines the processes of policy formulation, decision-making, and political interaction. The chapter concludes with implications that this theoretical framework has for the case of the Maldives.

\subsection{Democratisation}

In the last fifty years or so, most writers agree, that there have been several waves of democratisation of states, defined as a process where states move to greater degrees of electoral contestability, constraints on the power of the executive, and respect for individual freedoms. International measures of these changes (such as Freedom House or POLITY IV) suggest that they are neither universal nor irreversible. Thus much recent writing on democratisation as a process has focused on what factors are likely to be associated with a democratic transition and what factors are likely to be associated with its consolidation. This section outlines some of the underlying social and economic factors commonly cited as significant in democratic change as well as the importance of a country's past history and politically significant incidents. It also argues that some specific factors may be relatively more important in small-island states such as the Maldives. To present this argument, the section is divided into four main parts: democratisation as a process; causes of democratisation; results of democratisation; and democratisation and small-island states.

Before proceeding with the discussion of the above mentioned categories, a brief look into the nature of Islam in the Maldives is given here. The Maldives is an Islamic state: all written constitutions of the Maldives have established Islam as the state religion. There is also evidence that Islam is playing a larger part in party ${ }^{4}$ political activity since 2005, after being largely kept out of politics in the preceding

motivated and impartial civil servants working in a system dedicated to serving the public interest" (Organisation for Economic Co-operation and Development [OECD], 1997a, p. 5).

${ }^{4}$ The Adhaalath party was registered as a political party on August 18, 2005. It is a party based on Islamic ideology and is headed mostly by Islamic scholars (see "AP" in table 4.9 for the party membership). 
administration. The research for this thesis however uncovered no evidence that Islamic thought had any direct or significant influence on the development of the CS or its relationship to the democratisation process in the period under study and it therefore does not figure in the discussion of these processes which is the subject of the thesis.

\subsubsection{Democratisation as a process.}

Democratisation occurs when a nation moves from a less democratic form of rule towards a system that comprises basic democratic principles such as open competition, political participation, and civil and political liberties (see section 1.5.3). During this process, two simultaneous but somewhat autonomous processes occur - "a process of disintegration of the authoritarian regime, which often assumes the form of 'liberalization', and a process of emergence of democratic institutions" (Przeworski, 1986, p. 56). The transition from a less democratic form of governance to one that encompasses modern democratic principles is normally a lengthy process. Numerous categorisations of less democratic regimes exist in the contemporary literature. Rather than focusing on such regime types, attention here is focused on democracy and the features that characterise democratic systems.

A nation pursuing democratisation needs "open contestation over the right to win control of the government, and this in turn requires free competitive elections, the results of which determine who governs" (Linz \& Stepan, 1996, p. 3). This transition process can happen in a number of ways, and be gradual or sudden, violent or peaceful, moderate or absolute. Furthermore, as this is a process of change, "most writers conceive of it as a journey without end" (Burnell, 2008, p. 269) because full transition or consolidation is probably an elusive target.

A history of democratic culture is not necessary for a nation to pursue democracy (Diamond, 1993, p. 423). As discussed in the following section, democratisation can be the result of the combination of many factors. Democratic transition does not follow a linear path and is not a rational process by any means (O'Donnell \& Schmitter, 1986, p. 72). Often democratisation follows "an iterative process of constantly resonating reciprocal influences between actions, new institutions, new 
social forces or configurations, new environmental constraints and opportunities, and new perceptions, beliefs, and values" (Diamond, 1993, p. 423). As a result, the transition can take a number of different routes.

Typologies of democratisation processes have been presented by a number of authors including $\operatorname{Linz}^{5}$ (1978), and Share and Mainwaring ${ }^{6}$ (1986). Furthermore, Stepan (1986) listed at least ten alternative paths ${ }^{7}$ from nondemocratic regimes to political democracy. However, because of their clarity and relevance to the Maldives, the typologies of Huntington (1991-2) and Welzel (2009) are presented here.

Huntington (1991-2, p. 583) names three broad processes; transformation, replacement, and transplacement. According to him, in simple terms, transformation occurs when the elites in power take the lead in bringing democracy, replacement occurs when opposition groups take the lead in bringing democracy resulting in the collapse or overthrow of the authoritarian regime, and transplacement occurs when transition is the result of joint action of government and opposition groups. As evident, the focus in this typology is on government and opposition groups and the influence and power of those actors.

Welzel's (2009) typology of the democratisation process focuses on the participation or the absence of the general public during the democratic transition. Welzel (2009, p. 87) identifies responsive democratisation, enlightened democratisation, opportunistic democratisation, and imposed democratisation. Welzel (2009, p. 87) calls transitions driven by the masses, "responsive democratisation", the dominant type of democratisation witnessed in the emergence of nascent democracies in recent

\footnotetext{
${ }^{5}$ Linz (1978, p. 35) used the terms "reforma" and "ruptura". These terms could be considered equivalent to "transformation" and "replacement" respectively in Huntington's (1991-2) classification.

6 Share and Mainwaring (1986) used the terms "transaction", "breakdown/collapse" and "extrication". Once again these terms can be considered equivalent to "transformation", "replacement", and “transplacement” respectively in Huntington's (1991-2) classification.

${ }^{7}$ Those ten paths are: internal restoration after external occupation; internal democratic reformulation after external liberation; externally monitored installation; transformation led by authoritarian regime; transition initiated by military-as-government; extrication led by military-as-institution; transition led by society; transition led by opposition parties; violent revolt; and revolutionary war (Stepan, 1986).
} 
times. However, other forms of democratisation where mass action plays little or no part may also be evident in emerging democracies. For instance, Bhutan's democratisation process has been driven predominantly by the King, an unconventional transition (Turner, Chuki, \& Tshering, 2011) that Welzel (2009, pp. 87-8) would call "enlightened democratisation", which occurs "when negative historical experiences have discredited alternative forms of government" and the "elites effectively respect democratic standards even in absence of mass pressures to do so". Opportunistic democratisation (when the elites believe "they can easily corrupt democratic standards in practice and when the pretence of democracy is perceived as a useful means to open the doors to the international community" and donor agencies (Welzel, 2009, p. 88)), and imposed democratisation (when the "elites depend on the will of external powers and when these powers are pushing for democracy"), are two forms that are not driven by the pressure from the masses (Welzel, 2009, p. 88).

\subsubsection{Causes of democratisation.}

It is rare for a nation to pursue democratic transition for a single reason. Rather, often a combination of factors is required for democratisation to proceed effectively (Rossi \& della Porta, 2009, p. 182). As Pagnucco (1995, p. 151) has stated, the main reason for the need to combine perspectives from above and from below is that "the 'mode of transition', the context of the democratization process, the types of actors involved in the process, and their strategic interactions, all influence the kind of democracy that is established". Therefore, this section presents a number of probable factors that may drive a nation towards democratic transition. The factors presented here are: political elites, mass movements, societal groups, significant incidents, economic and social development, globalisation and media, and international community. 


\section{Political elites.}

Often a number of organisations or actors within a society are responsible for moving the democratisation process forward. Among them, political elites ${ }^{8}$, both existing and those that emerge during the democratisation process, arguably play a central role. Their contribution can be important in determining the success or failure of the process (Kotze \& Du Toit, 1995, p. 34). For elites to support democratic reforms, either there should be a widespread belief among them that democracy is the best form of government for the society (Diamond, et al., 1987, p. 7), or they believe that their interests will be better served when they back the democratic movement to dismantle the authoritarian regime (Przeworski, 1986; Stepan, 1986, p. 72). Such support from the elites may be the result of modernisation because, as Welzel and Inglehart (2008) state, with modernisation, ordinary people's capabilities and willingness to struggle for democratic reforms increase which puts effective pressure on elites.

Effective pressure by the general public can also result in splitting the existing elites who either support or resist democratic reforms. When such a split occurs a liberal reform camp will emerge that assists the transition towards democracy (Higley \& Burton, 2006; O’Donnell, Schmitter, \& Whitehead, 1986, cited in Welzel, 2009, p. 83). This might be due to a number of reasons, some of which are addressed in the following sections. Such a liberal camp will then try to regain legitimacy for the elite by initiating a liberalisation process which may lead to a negotiated transition to democracy (Welzel, 2009, p. 83). However, such a negotiated and peaceful transition is possible only when the majority of the political actors within the regime, as well as

\footnotetext{
${ }^{8}$ Defining the term "Political Elite" is a theoretical morass with a long history. A recent definition provided by Burton and Higley (2001, p. 182) defines political elites as "the several thousand persons who hold top positions in large or otherwise powerful organizations and movements and who participate in or directly influence national political decision-making". They are from all facets of the society "who have the organized capacity to make real political trouble" (Burton \& Higley, 2001, p. 182). In addition, Blondel and Müller-Rommel (2007, p. 821) state that, "all persons with specific individual resources such as income, prestige, education, and occupation may in principle belong to the political elites. Thus, the political elite in modern democracies consist of distinct groups of individuals with varying socio-demographic backgrounds and occupational positions". Although different labels are used to refer to the same concept and different concepts are covered by the same label, many authors including Bottomore (1964), Dahl (1970), Guttsman (1960), Lasswell (1961), Meisel (1962), Mills (1956), Mosca (1939), Pareto (1935), and Zuckerman (1977) have contributed to the literature.
} 
the opposition, are willing to negotiate during the transition process. Failure to negotiate, or unsuccessful negotiation, may lead to civil unrest.

\section{Mass movements.}

As important as the political elites are in the democratisation process, the power of ordinary people, the mass public, has also been a significant force in many democratic transitions. The Arab Spring is a recent example where popular uprising was significant in the initial stages of a transition. Schedler and Sarsfield (2007) argue that the public may prefer democracy for superficial or instrumental reasons (cited in Welzel \& Inglehart, 2009, p. 129). Superficial reasons include pursuing of democracy because it has become socially desirable with positive connotations (Inglehart, 2003, cited in Welzel \& Inglehart, 2009, p. 129), whereas instrumental reasons involve pursuing democracy in the belief that it will bring economic prosperity rather than for reasons such as political freedom (Bratton \& Mattes, 2001, cited in Welzel \& Inglehart, 2009, p. 129).

On the contrary, Welzel and Inglehart $(2006,2009)$ argue that only when preferences are intrinsically driven - that is when the masses place a high value on freedom and self-expression ${ }^{9}-$ is it likely that the people will actively pursue democratisation. In the absence of intrinsic preferences, and in cases where people's expectations are not fulfilled through democratic governance, reversion to autocratic rule is also a possibility.

In addition to intrinsic preferences towards democratisation, the conduciveness of a nation's political culture to democratic reforms is also an important element, though not a necessity. While Diamond (1993, pp. 7-8) defines political culture as "a people's predominant beliefs, attitudes, values, ideals, sentiments, and evaluations about the political system of its country, and the role of the self in that system",

\footnotetext{
${ }^{9}$ Components of self-expression values include tolerance, trust, political activism, and greater emphasis on freedom of speech; more specifically it includes values such as tolerance towards homosexuals, willingness to trust others, willingness to sign petitions, describing oneself as very happy, and giving priority towards self-expression and quality of life over economic and physical security (Inglehart, 2003; Inglehart \& Baker, 2000).
} 
Verba (1965, p. 513) defines it as "the system of empirical beliefs, expressive symbols, and values which defines the situation in which political action takes place”. Simply, political culture concerns the sentiments of the people in relation to political action. In transitions led by mass movements, it is important that the masses are in favour of drastic changes and do not believe that the status quo fulfils their ambitions and demands. In other words, during mass-led transitions, a majority of the public is likely to favour democratic change and embrace democracy as better than any other form of political system. In addition, when a "set of values, beliefs, and attitudes that fosters toleration, bargaining, and compromise" (Payne \& Nassar, 2010 , p. 180) is present, or when there is a willingness to tolerate diversity and conflict among various groups as well as when the legitimacy of compromise is recognised by all parties (Huntington, 1984, p. 209), the probability that the transition will succeed is likely to be greater.

\section{Societal groups.}

Interest groups such as political parties and civil society organisations (CSOs) are also important players in emerging democracies. In countries where political, economic, and societal liberalisation takes place prior to democratic reforms such groups can be leading forces in the drive towards democratisation. Morlino (2009) states that political parties are an essential component of democracy and they are dominant in the transition process as well although they are not always hegemonic. A lively civil society has also been considered essential for democratic consolidation (Letki, 2009) and some even list civil society as one of the key spheres necessary for the modern democratic system to emerge and function (Linz \& Stepan, 1996, p. 7).

\section{Significant incidents.}

Politically significant incidents sometimes trigger attitudinal changes within political elites and the mass population that, in turn, support a process of democratisation. An event in Tunisia that triggered the Arab Spring is one recent example. One also needs to note that, although a single, particularly dramatic event may be a turning point in mass action, such a dramatic event often is a manifestation of a culmination of a series of events (Linz, 1990, p. 157). 
Mass demonstration or political violence can mark the start of this process. Welzel (2009, p. 89) states:

If people have acquired both the capability and the willingness to join forces in struggling for democratic freedoms, and if there is reason for grievance because these freedoms are denied, deficient or challenged, at some point a critical event will prompt people to actually act together for these freedoms, be it to establish, to deepen or to defend them. Provided these actions grow strong enough, power elites will be forced to give in to their demands. When this happens we witness mass responsive democratization.

Though the start of the transition may be due to such incidents, the process may not be smooth. Huntington (1991-2, p. 610) observes, the road towards transplacements is "often marked by a seesawing back and forth of strikes, protests, and demonstrations, on the one hand, and repression, jailing, police violence, states of siege, and martial law, on the other". In such cases, there is no single mass uprising that sweeps the established order from power. Both the government and opposition are incapable of changing the status quo, and after testing each other's strengths and weaknesses, a political dialectic is initiated which leads to further democratisation (Huntington, 1991-2, p. 609). In most cases such transitions are lengthy and often involve several setbacks before eventual agreement is reached among the political elites.

\section{Economic and social development.}

Although economic development arguably leads to the rise of a middle class which is considered a crucial social requisite to foster a democracy (Pei, 2002, p. 4), "economic development compels the modification or abandonment of traditional political institutions; it does not determine what political system will replace them" (Huntington, 1984, p. 201). In particular, capitalism and democracy can exist independently from one another and one does not necessarily lead to the other (Grugel, 2002, p. 240). There are capitalist nations that are not considered democratic (China, for example) and though it has been rare, history shows there were non-capitalist democracies (for example, Chile under the rule of Salvador 
Allende). Such examples show that the point made by Lindblom (1977, pp. 161-9) appears almost precise - that though all political democracies have market-oriented economies, not all market-oriented economies are paired with democratic political systems. Nonetheless, though capitalism and material development are not essential preconditions for democratic transition, growth in personal wealth may increase its likelihood. In this regard, Lipset $(1959$, p. 75$)$ has stated that the "more well-to-do a nation, the greater the chances that it will sustain democracy”.

\section{Globalisation and media.}

Globalisation is defined as the "processes whereby many social relations become relatively delinked from territorial geography, so that human lives are increasingly played out in the world as a single place" (Scholte, 2001, pp. 14-15). There are numerous other definitions of "globalisation" (see Held, McGrew, Goldblatt, \& Perraton, 1999; Teichmann, 2002, p. 4; Zolo, 2007, p. 1). For smaller states the impact of globalisation has meant "that their control over the movements of money, commodities, people and information across their borders has entered a process of decline" (Yilmaz, 2009, p. 101), making them susceptible to daily global forces.

The effect of globalisation can also be significant during the democratisation process, especially for smaller states due to their dependence on and openness to the outside world. The pressure on less-democratic nations to embrace the principles of democracy has increased exponentially, especially after the end of the Cold War. ${ }^{10}$ In the recent past, established democracies and multi-national bodies have promoted democracy under the banner of "good governance". Though a number of influential nations are firm believers in "Westphalian sovereignty", for most nations, the principle no longer applies when a nation represses its own citizens. In other words, "states no longer have the right to treat their citizens as they think fit" (Held, et al., 1999). The principles of human rights are given a high degree of importance. Cases in point seen over the last two decades include the intervention in Bosnia and more recently in Libya. Some exceptions include Syria and North Korea, cases which are

\footnotetext{
10 "Cold War had imposed restrictions on the ability of Americans to criticize American allies who violated their citizens' rights" (Payne \& Nassar, 2010, p. 184).
} 
not resolved due to a number of reasons including the reluctance of U.S. to get embroiled in yet another war, and the exercise of veto by Russia and China in the Security Council.

In this global village, advancements in information technology and mass media have meant that the sovereignty of individual nations to determine their own affairs in the face of globalisation is eroding (Saward, 2003, p. 93). Mass media are a dominant actor in our day-to-day lives. In addition to conventional sources such as newspapers and television, internet and social networking sites also act as sources of information from which people learn about what unfolds domestically and globally. The reaches of an independent media can be fundamental during a democratisation process as the "media enable the citizens to make informed choices by seeking out information about the political alternatives at hand" (Voltmer \& Rawnsley, 2009, p. 235). The media can therefore play a prominent role in focusing and organising resistance to the status quo of the polity. Media are also crucial in ensuring that democratic institutions work effectively thereby improving the quality of the democratic process (Cheema, 2005, p. 228). In what is often referred to as the "fourth estate", the media have a powerful role in making governments and political actors accountable, in revealing acts of corruption and abuse of power by state officials. Therefore, independent and effective media contribute towards determining public opinion and thereby help to drive the process of democratisation.

\section{International community.}

The international community and donor agencies can also have an impact on the emergence of democracy, especially in recipient countries expecting significant gains from donors. For example, if a state wants to join the European Union (EU), it is required to have or develop the laws and institutions of democracy as a condition of accession. When development aid is tied to democratic reforms - mostly under the banner of "good governance" - required by international agencies such as the World Bank (WB) as well as individual governments, the extent to which the receiving nations are able to accept such preconditions can have an influence on the transition

process. For instance, the U.S. Agency for International Development (USAID) spends around US\$650 million annually on programmes related to the promotion of 
democracy (Carothers, 1999, p. 48). However, it is important to highlight here that although foreign influences can have a significant impact during the transition phase, the ultimate consolidation of democracy in a given case will be determined by domestic forces (Linz \& Stepan, 1996, p. 73). Furthermore, L. Whitehead (1986, p. 31) stresses that during peacetime, internal factors of the nation determine the success of democratic transitions and external support becomes of secondary importance. Knack (2004), in his multivariate analysis of the impact of aid on democratisation in a large sample of recipient countries over the period 1975-2000, found no evidence of aid promoting democracy in those nations. Therefore, the exact impact the international community has on the democratisation process may vary from country to country and thus requires a cautious examination.

\subsubsection{Results of democratisation.}

As mentioned previously (section 1.5.4), the breakdown of a nondemocratic regime and the beginning of the establishment of democratic order do not necessarily ensure a smooth consolidation of a democratic political culture. History shows reversal to autocratic rule is also a possibility. The state of each nation, inclusive of all factors that may have an impact on the political culture, determines the route each nation follows. This section presents four possible end results of transition towards democracy.

\section{Consolidated democracies.}

As mentioned in the previous chapter (section 1.5.4), democratic consolidation is reached when democracy is seen by all actors as the "only game in town" (Di Palma, 1990, p. 113). In other words, consolidation is reached when what Rustow (1970, p. 358-61) refers as "habituation" is achieved: all aspects of democracy are ingrained among the actors so that they conform to written and unwritten rules even during conflict and competition (Diamond, 1999, p. 65). The elites, state institutions, and the public all believe that their political system is worth obeying and defending (Diamond, 1999, p. 66). When such a stage is reached, it can be safe to conclude that the transition to democracy is complete. In the political dealings among the actors "abnormality" will no longer be considered a central feature when the transition is 
over (O’Donnell \& Schmitter, 1986, p. 65). By then democratic maturity and consolidation is reached. Linz (1990, p. 158) states that consolidated democracy is:

one in which none of the major political actors, parties, or organized interests, forces, or institutions consider that there is any alternative to democratic processes to gain power, and that no political institution or group has a claim to veto the action of democratically elected decision makers. This does not mean that there are no minorities ready to challenge and question the legitimacy of the democratic process by nondemocratic means. It means, however, that the major actors do not turn to them and they remain politically isolated.

It is also important to point out that sustainable democracy is achieved only through socially embedded democracy, which in turn is achieved mostly through mass responsive democratisation (Welzel, 2009, p. 89) mentioned earlier (see sections 2.2.1 and 2.2.2).

\section{Restricted democracies.}

According to Sørensen (1998, p. 46), "restricted democracies are political systems with some democratic elements but also with limits on competition, participation, and liberties". Also known as "guided democracy", a classical example is Indonesia under the rule of Sukarno. In such nations, authoritarian rule may have been replaced by a form of democracy that has provided a degree of competitive elections and political liberties. However, due to the restrictions placed on democratic attributes, such nations are considered restricted democracies. In these countries one fundamental aspect of democracy is commonly missing, namely "an arena of contestation sufficiently fair that the ruling party can be turned out of power" (Diamond, 1999, p. 15). Diamond, Linz, and Lipset (1995, p. 8) refer to such regimes as pseudodemocracies, "because the existence of formally democratic political institutions, such as multiparty electoral competition, masks (often in part to legitimate) the reality of authoritarian domination". Though there are wide variations even among such nations, the basic feature appears to be limited competition due to application of autocratic modes to prevent open competition regardless of the tolerance towards multiple parties. 


\section{Frail, unconsolidated democracies.}

Most democracies that transit from authoritarian rule to democratic rule fall into the category of frail and unconsolidated democracies, at least initially. At times, they are also referred as emerging or nascent democracies. Due to a number of factors that include the lack of adequate time for democratic characteristics to institutionalise in the polity, such democracies lack some of the features evident in consolidated democracies. Some of the reasons behind the frailness and the characteristics of such democracies are presented below.

Institutional weaknesses are arguably one of the biggest challenges facing an emerging democracy particularly in imposing effective constraints on arbitrary action by the executive. The professional capacity and institutional setup of state organisations, political parties, and CSOs can have a crucial impact on the development of democracy, especially during the early stages. However, "institutional weaknesses, including ineffectual political parties and an absence of effective checks and balances on the chief executive" (WB, 2005, cited in Kapstein \& Converse, 2008, p. 4) are commonly found in emerging democracies. Checks and balances are particularly important in nations where new institutions are created as part of the democratic process. Additionally, in oppositional party-based political systems, the functioning of strong opposition parties is important in flourishing democracies because they can prevent abuses by the leadership (Kapstein \& Converse, 2008, p. 26). Furthermore, tolerance and civility among the parties may also need to be developed over time. In this regard, some argue that at times there needs to be a more phased and gradual transition to democracy so that parties can learn to live with one another and establish a system of mutual security (Diamond, et al., 1987).

Defining the boundaries of state institutions can also be problematic in nascent democracies. This complicates what O'Donnell (1996) refers to as "horizontal accountability" - a system where control mechanisms are placed on state agencies by other state agencies to prevent the sanctioning of unlawful or inappropriate actions of state agents - and how that accountability is to be applied. The boundaries between the institutions of such democracies may be vaguely defined and "even when such 
power may be defined clearly on paper, the actual mechanisms of enforcement do not exist, allowing opportunistic political leaders to trespass on the prerogatives of other institutions" (Pei, 2002, p. 14). In addition to the three arms of the state executive, judiciary, and the legislature - a number of other organisations such as those responsible for auditing, and investigating corruption and human rights abuses acts to oversee the functions of the three arms in most nations. The proper functioning of the legal roles of such organisations and how they interact with other state organs can determine the time period for the nation to become a mature democracy. In a case study of seven East Asian and Pacific countries, Laking (2008) concluded that for such overseeing bodies to succeed a number of factors are important. They include a political climate that at least tolerates the activities of those institutions; operational independence from the executive; reasonably secure and adequate funding; powers of investigation; a public profile and some support from civil society and the media; and the ability of the institutions to get their findings and recommendations implemented. The presence of such factors will arguably be an important element in preventing abuse of power and cementing the democratic transition.

In many emerging democracies, even those that entrench freedom of the press as a constitutional principle, political interference and control of the media can be the reality. ${ }^{11}$ Unwillingness to give up control of state media, politicisation of appointment of boards for public broadcasters, interference of democratically elected politicians towards independent media are all features evident in nascent democracies (Voltmer \& Rawnsley, 2009). According to Voltmer and Rawnsley (2009, p. 241), "one of the main reasons why governments are reluctant to give up control over the media is the lack of alternative communicative links with the citizens, such as effective party organization". Furthermore, media themselves might be politically inclined towards one or other political factions with opinionated and politicised reporting rather than neutral and balanced reporting (Voltmer \& Rawnsley, 2009, pp. 243-4).

\footnotetext{
${ }^{11}$ Even in mature democracies, establishing a control mechanism for the media can be an issue. After the phone-hacking scandal, debate on control of the media has re-emerged in the UK - a nation with a centuries-old tradition of press freedom.
} 
Due to such challenges in frail democracies, Polterovich and Popov (2007, p. 39) state that building a democracy "should be gradual, rather than shock therapy type, and should go hand in hand with the strengthening of law and order". The consolidated democracies of the West themselves are prime examples of this because democracy was not installed overnight in those countries; rather it was a long-term process of gradual change (Sørensen, 1998, p. 52). Furthermore, Huntington (1984, p. 214) states that:

the probability of stable democracy emerging will be enhanced to the extent that the transition can be a gradual one, that the introduction of contestation precedes the expansion of political participation, and that the role of violence in the transition is minimized.

Depending on the readiness of the nation to embrace democratic ideals, a number of repercussions can be evident during the consolidation and sustaining of democracy. Misra (2004, p. 142) in his studies of Maldives, Bhutan, and Nepal, concluded that "hasty introduction of Western-style democracy may not be conducive to certain societies" and small states that have introduced democracy gradually have been more successful in maintaining law and order. Therefore, the speed at which democratic reforms are undertaken can have a bearing on the road towards maturity as the awareness of and readiness of the general public for democracy ultimately decides the final outcome.

\section{Failed democracies.}

Failed democracies are polities that at one time show promise as potential democracies but move toward authoritarianism and reversal of democratic principles. As Fish and Wittenberg (2009, p. 251) explain, such countries "have an experience of political opening but subsequently underwent a major reversal". Observers have provided different reasons for such failures. Rabushka and Shepsle (1972) argue that ethnically "diverse societies are more prone to conflict and less able to generate the compromise that is integral to democratic practice" (cited in Fish \& Wittenberg, 2009 , p. 253). Furthermore, high dependence on income received from oil and gas, a 
large Muslim share of the population, and sex inequality has also been considered to be inversely related to successful democratisation (Fish \& Wittenberg, 2009).

Fish and Wittenberg (2009, p, 258) identify five agents with the potential to derail democracy: (1) a public that overthrows the government in an uprising; (2) insurgents that instigate civil war; (3) foreign powers that invade the country or provide support for anti-government elements; (4) armed forces that carry out a coup d'état; and (5) chief executives that engage in despotic actions. One or a combination of these elements may result in reversal to autocratic rule.

\subsubsection{Democratisation and small-island states.}

How does being a small-island state affect the process of democratisation? During the democratisation process there is: (1) negotiation of the institutional changes of democracy; and (2) subsequent resolution of conflicts in a way that protects those institutions. Small polities have relatively distinct features when compared to larger polities, and those features can be a factor during this process (also see section 2.5).

According to March and Olsen (1984, p. 738), "political democracy depends not only on economic and social conditions but also on the design of political institutions". The constitutional arrangements of the nation also form part of this political institution. Stepan and Skach (1993, p. 2) argue that constitutions represent the "institutional frameworks" which provides "the basic decision rules and incentive systems concerning formation, the conditions under which governments can continue to rule, and the conditions by which they can be terminated democratically". However, are successfully democratising small-island states more likely to have one form of constitutional architecture than another?

There is some evidence supporting a correlation between the choice of formal institutions and smallness and islandness. Anckar (2006) argues that small-island states are more likely than other states to have a parliamentary system, support plurality-based electoral systems and employ "direct democracy" in the form of referenda and initiative ballots. Anckar (1996) also found that in small-island states that are archipelagos, specific consideration is given by constitution-makers to 
representation in the national assembly of smaller island communities and often also to decentralisation of governance and administration.

A number of studies have focused on state size and democracy. Ott (2000), used a cross-national multiple case study along with statistical data for all nations during the period 1973-1995. The study's central hypothesis was that state size does impact the formation and maintenance of democracy in small states. Ott hypothesised that those effects were the consequences of the social systems (such as informal patterns of interaction and overall cooperativeness among societal members) in small states. Such social interactions would in turn change the political and economic environment, and affect state behaviour at the system, group, and individual levels, affecting the democratisation process of those states (Ott, 2000, pp. 9, 195, 196). By using a variety of methods, including time series analysis, she concluded that small and island states are more likely to be and remain democratic. A study conducted by the Commonwealth Secretariat (1997) also concluded that small states are more likely to be and remain democratic irrespective of the level of economic development, and to show continuous political stability. Anckar (2008) also concludes that small country size is conducive to the growth of democratic principles. Therefore, small-island states can be seen as "a welcome antidote and contrast to the anarchy, autocracy, internal warfare, militarism, violence and state collapse which is a feature of all too many larger, mainland states" (Srebrnik, 2004, p. 339).

Cultural attributes can play an important role in maintaining a civil political environment that is conducive to fostering a democracy. Grugel (2002, p. 246) insists that there is a common argument that it is easier for liberal democracy to institutionalise in Western cultures mainly because of their emphasis on individualism. ${ }^{12}$ Cheema (2005, p. 215) also argues that in cultures where people avoid extreme forms of individualism in their behaviour, this negatively affects the

\footnotetext{
${ }^{12}$ Among the four main cultural dimensions explained by Hofstede (1991), individualism and collectivism express how the individual affiliates himself or herself to the society. According to Hofstede (1991, p. 51) "individualism pertains to societies in which the ties between individuals are loose: everyone is expected to look after himself or herself and his or her immediate family. Collectivism as its opposite pertains to societies in which people from birth onwards are integrated into strong, cohesive in-groups, which throughout people's lifetime continue to protect them in exchange for unquestionable loyalty."
} 
process of democratisation. It is perhaps paradoxical that while social closeness reinforces collective decision-making of democracies, it limits individual selfexpression that appears stronger in individualistic societies. Nonetheless, it can be argued that despite the cultural affinity for collectivism and other related attributes evident in small states, small-island states can, over time, still emerge as mature democracies, as small country size has been shown to be conducive to democracy (Frye, 2002, p. 86).

Some social features of small-island societies may enable conflicts to be resolved within a democratic framework thereby aiding democratic consolidation along the way. Members of the governing elite in small states cannot ignore their social interconnectedness when exercising authority (J. Richards, 1982). For instance the importance and influence of political elites are likely to be greater in small states thus allowing them to implement the "choice" to pursue the democratic bargain easily (Ott, 2000, p. 81). In other words, such elites are able to lead mass opinion and the outcome of their negotiations is more likely to be accepted by the wider public.

This does not imply that political differences will not be visible in small states and small-island states. Political differences are unavoidable in a democratic polity, but how those differences are dealt with and resolved determine the maturity of a democracy. The societal closeness evident in small states means that when political differences arise they are "more personal, more intense and more emotionally charged" (Brown, 2008, p. 7; J. Richards, 1982, p. 159) than in larger societies. However, some argue that in small states it is not practicable to play politics as a zero-sum game and so the politicians learn to adopt a more consensual style and avoid the extreme hardline positions that are possible in larger countries (Lijphart, 1977, p. 65). In this respect, Anckar and Anckar (2000) argue that extreme smallness of the nation, an extremely archipelagic geography, and an intense cultural resistance to divisions in the society can lead to flourishing democracies, interestingly even in the absence of political parties, which are often presumed to be divisive institutions.

Geographical isolation coupled with smallness of island states can also be a factor in democratisation. Anckar and Anckar (1995) argue that a combination of smallness and remoteness hold quite specific democratic promises. They argue that people 
living at a distance from the outside world are likely to develop a spirit of community and solidarity leading to the emergence of feelings of tolerance and communication, and that the distance between the governors and those who are governed is lessened as the two share the same challenges (Anckar \& Anckar, 1995). Furthermore, it is also likely that the relative unimportance of some of the island states mean that colonising powers were less likely to intervene in the internal affairs or manipulate the institutional development of such states. Therefore, such countries may have been left to develop institutions on their own terms.

\subsection{Theory of contemporary civil service}

\subsubsection{Historical overview.}

Substantial evidence from the work of anthropologists and archaeologists suggests the existence of organised government and public officials dates to around 6000 B.C. (Gladden, 1972a, p. 1). At that time organisations and functions would have been much simpler. Record keeping would have not existed until writing was invented much later, and probably emerged due to the need for counting. However, the comparatively well-documented Egyptian civilisation that existed from around 3400 to 525 B.C. provides a starting point for the study of government (Gladden, 1972a, p. 45). With time and the rise of different civilisations such as Greek, Roman, Indian, Chinese, and Ottoman, the operation of the state with its more advanced political and social institutions became increasingly complex.

The Constitution of Melfi issued by Frederick II of Sicily in the year 1231 has been called the "birth certificate of modern bureaucracy" (Jacoby, 1973, p. 21, cited in J. C. N. Raadschelders \& Rutgers, 1996, p. 73). With time and the dissolution of feudalism, new urban civilisations started to emerge. Such developments eventually led to the birth of the modern CS, from the nineteenth century into the 1930s (J. C. N. Raadschelders \& Rutgers, 1996). Some date the modern CS from the establishment of the British Civil Service in 1853 through the Macaulay reforms relating to recruitment of the Indian Service (Gladden, 1945). In this regard, some consider the term civil service as an Indian input to the field of public administration when it was used to differentiate government and military officials by the British 
Government in Punjab in late eighteenth century (Mishra, 2001, p. 120). However, Van der Meer, Steen, and Wille (2007) date the birth of the modern CS from the drive for codified CS legislation in Prussia in 1794.

Professional CS is by no means an exclusively Western concept. However, in the nineteenth and twentieth centuries, most international exchange of ideas of the CS has been based on European and U.S. exemplars, mainly but not exclusively as a result of colonisation, and therefore, the focus in the next section is on the evolution of the principles of the CS in those countries.

\subsubsection{Evolution of civil service models in Europe and the United States.}

This section examines the development of the CS model in the European-American context. J. C. N. Raadschelders and Rutgers (1996) identify five phases in the evolution of the CS systems with a focus on the European continent: civil servants as personal servants; civil servants as state servants; civil servants as public servants; the CS as protected service; and the CS as professional service. It is also possible that a similar division of roles may have developed much earlier in Egypt and China, for example.

The first phase in Europe is considered to be during the thirteenth century when the monarch employed three types of servants - court staff, army, and civil servants ( $\mathrm{J}$. C. N. Raadschelders \& Rutgers, 1996, p. 71). Such developments were the result of reshuffling of power between clergy, aristocrats, and kings that provided for an administrative apparatus (J. C. N. Raadschelders, 1998, pp. 149-50). During the second phase, when civil servants were considered state servants, a greater degree of formalisation in administration was in place. In the course of the fifteenth and sixteenth centuries, the focus started to shift from the betterment of the monarch to the provision of public welfare which was mainly the result of territorial expansion of states and the increasingly growing interaction with other states (J. C. N. Raadschelders \& Rutgers, 1996, pp. 74-8). Civil service started to take shape during that stage, though not with features similar to those evident in the present day. In the next phase, from 1780 to 1880 , the civil servant was no longer directly responsible to the monarch, but to a civil sovereign power (J. C. N. Raadschelders \& Rutgers, 1996, 
pp. 78). A civil servant was not seen as an officeholder but as an employee of the state during this stage (Church, 1981), though the service was still plagued with patronage (Gladden, 1972b). Developments during this third stage included introduction of ranking of staff, provision of regular salary with provision for pension, and written procedures to govern administrative tasks (J. C. N. Raadschelders \& Rutgers, 1996, pp. 78-81). Politics and administration became differentiated during this third stage, providing a major platform for the development of the modern CS (Chester, 1981, p. 315; Nelson, 1982, pp. 119-133; Parris, 1969, p. 33; J. C. N. Raadschelders, 2003, p. 310).

In the fourth stage, during the period of industrialisation of the nineteenth century, the CS turned into a professional service (J. C. N. Raadschelders \& Rutgers, 1996, p. 83). With the expansion of public services provided by the government, the CS grew along with extensive regulations. Civil servants became more aware of their rights and consequently demanded legal protections and guarantees from the state. The Kingdom of Bavaria (currently a state of Germany) was one of the first in 1805 to pass a CS Act (Hattenhauer, 1979, p. 183; Heyen, 1989, cited in J. C. N. Raadschelders \& Rutgers, 1996, pp. 83-4). The fifth phase was focused on the building and continuation of the processes of professionalisation and specialisation that were the hallmark of the previous stage. Legislation governing the CS had become the norm with increasing attention towards performance and elimination of red-tape in the bureaucracy. The CS also became the subject of extensive criticism for its growing size, lack of efficiency and representativeness (J. C. N. Raadschelders \& Rutgers, 1996, pp. 86-9). J. C. N. Raadschelders (2003, p. 327) suggests that the fourth and the fifth stages elaborate the third stage because the civil servant continued to support the elected officials and in return civil servants received protection through law and political accountability.

Butler (1993) identified four phases in the evolution of the CS in Britain: (1) from the 1854 Northcote-Trevelyan report until the Warren Fisher reforms in the 1920s; (2) extensive growth in the size of the CS, which he termed the "cloistered profession" between 1930s and 1960s; (3) from the Fulton report until 1979, a period with emphasis on accountability, efficiency, and professionalism; (4) following Margaret Thatcher's electoral victory in 1979 into the 1990s - a period Butler (1993) 
suggests, of direct initiatives specifically targeted at the CS that turned an evolutionary process into a "revolution".

Among the time periods mentioned by Butler (1993), arguably the most influential period followed the Northcote-Trevelyan Report of 1854. Some assert that the report sought to create a more efficient public service and a purer and more strenuous ethic in public life (Hart, 1972). Others have noted that the report was evolutionary, rather than revolutionary (Hennessy, 1989; D. Richards, 1997) due to the growth of the state which meant that the bureaucracy had to cope with the new pressures placed on it. D. Richards (2003) notes that as the responsibility of the state grew, politicians needed permanent advisers and staff to implement their policies thereby replacing the former patronage system.

The CS evolved differently in the United States than it did in Europe, and Ingraham and Rosenbloom (1990) have identified four dominant models of the American Public Service: (1) an arm of the ruling elite; (2) an extension of political parties; (3) an apolitical, technical, and managerial public service; and (4) an extension of the chief executive.

In the first model, from 1789 to 1828 , the belief was that federal service should be an arm of the ruling political elites. Patronage was an accepted norm and politics and administration were considered the domain of the upper social class (Ingraham \& Rosenbloom, 1990, pp. 212-3). The second model, from the late 1820 s to the 1880 s, was an extension of the first model. The party which captured both presidency and a majority of congress had the federal CS at their control, which meant a high turnover after a change of government at elections (Ingraham \& Rosenbloom, 1990, p. 213). Calls to depoliticise the federal service led to major reforms and the advent of the third model. The Pendleton Act of 1883 was considered a turning point. In addition to depoliticisation of public service, providing efficient and effective regulation and service delivery through principles of scientific management were prime objectives (Ingraham \& Rosenbloom, 1990, p. 213).

There were numerous differences between the American and British models. For one, the American model did not include a base-grade entry and political 
appointments were maintained for senior positions (Halligan, 2007, p. 54). It allowed open competition for promotions as well as entry examination and the emphasis was on practical skills and knowledge in the examination rather than on academic credentials and knowledge as is practiced in Britain (Ingraham, 1995, p. 27). The aim in U.S. was to deal with the patronage through political means with the use of executive orders rather than through legislative action (Ingraham, 1995). Furthermore, politics intruded into the CS and the CS was also at times involved in politics more openly in American federal bureaucracy compared to the European nations (Suleiman, 2003, p. 17). Such different evolutionary paths were mainly due to the difference in the system of government.

The fourth model evolved during the New Deal that "viewed the public service as the domain of the elected executive for policy implementation and formulation" (Ingraham \& Rosenbloom, 1990, p. 213). This was not a major departure from the previous model, but the main difference was a change of emphasis from scientific management to executive control, that contributed to the growth of several institutions outside the CS system (Ingraham \& Rosenbloom, 1990, pp. 213-4).

The evolution of CS models in the European-American context can thus be summarised into a number of main themes. They include: the development of a system of public employment that would fit the development of more complex and rule-driven systems of public administration; the constant and on-going tension between employment based on patronage and on qualifications for administrative tasks (merit); the efforts to define a distinct zone of administration that would be the domain of the civil servant; the associated demarcation of "policy" and "administration"; the growth of the ideas of hierarchy and career in the CS; and the evolution of the bargain between the professional civil servant and politician in which a guarantee of secure lifetime employment was given in return for unquestioning loyalty and obedience. Such features form part of what is referred as "Weberian" principles, discussed in the next section. 


\subsubsection{Civil service models in contemporary times.}

Bureaucracy ${ }^{13}$ is a central institution in any state. Max Weber was the first to identify bureaucracy as a system of administration that is carried out on a continuous basis by trained professionals guided by prescribed rules. He identified eleven features as pertinent to such organisations (see Weber, 2007), which Beetham (1996, p. 9) subsequently reduced to four: (1) a predefined hierarchy for each official with division of labour; (2) continuity of the job with an organisational structure that offers regular advancements; (3) impersonality of the tasks where rules act as guides and records are maintained; and (4) focus on expertise where officials are hired on merit and trained for the tasks.

Weber's model of analysing administrative systems focused mainly on organisations as systems of power or domination in which the leader exercises control over and through a hierarchy of officials who both receive and give orders. To Weber, bureaucracy provides the basis for a more stable and predictable administrative structure for both superiors and subordinates. According to Weber (Parsons, 1947, p. 328), there are three types of legitimate authority: (1) legal-rational authority "resting on a belief in the 'legality' of patterns of normative rules and the right of those elevated to authority under such rules to issue commands"; (2) traditional authority - "resting on an established belief in the sanctity of immemorial traditions and the legitimacy of the status of those exercising authority under them"; (3) charismatic authority - "resting on devotion to the specific and exceptional sanctity, heroism or exemplary character of an individual person, and of the normative patterns or order revealed or ordained by him". Among these types of authority, legal-rational authority is associated with more impersonal specific and formal structures which when highly developed becomes more compatible with bureaucracy. Weber thus defines bureaucracy as a particular type of administrative structure, developed in association with the legal-rational mode of authority.

\footnotetext{
${ }^{13}$ It is believed that the term "bureaucracy" was first used in the middle of the eighteenth century by the French civil servant and physiocrat Vincent de Gournay (1712-1759) (J. C. N. Raadschelders, 2003 , p. 316). "Bureaucracy is not limited to government, since large organizations of men and women are not peculiar to government" (Hyneman, 1950, p. 4). However, normally "only civil servants and public organisations are identified as the bureaucrats and bureaucracy" (Demmke, 2005, p. 22). In this research the focus will be on governmental bureaucracy, specifically on central government.
} 
Although the terms "civil service" and "bureaucracy" are often used interchangeably, there is a clear distinction between the two. In basic terms, the institution of CS comprises rules of employment governed by a uniform written code accompanying a judicial mechanism for resolving issues in the application of that code and is clearly and exclusively associated with the state, whereas bureaucracy is the mode of organisation within which the CS operates.

In the present day, bureaucracy is often described in terms such as "centralized", "hierarchical", "specialised", "slow", "inefficient", "cumbersome", “inflexible", "formalistic", "red tape", "hostile to discretion", "non-transparent", "too expensive", “over-regulated", “corrupt", "egoistic” (Demmke, 2004, p. 55; Demmke, 2005, pp. 2-3; K. M. Henderson \& Dwivedi, 1999, p. xiii; J. C. N. Raadschelders, 2003, pp. $313,316)$, and many other similar terms with the connotation of rigidity. As is common with other traditional principles of the CS, rigidly enforced rules and regulations have also evolved considerably over the years, with variations evident in different countries' CS systems.

Challenges facing the CS have meant that the evolution of the CS models over the centuries has been significant. Reforms directed at the CS have ensured that by the start of the twenty first century there remains no national CS model that can be entirely described as a classical career model (Demmke, 2004, p. 91), a feature that has remained a hallmark since the birth of the modern CS. It appears that the specific characteristics of classical career models ${ }^{14}$ "no longer fit modern requirements for flexibility, adaptation and more variety" (Demmke, 2004, p. 92). However, this does not imply that traditional elements no longer exist. According to Lægreid and Wise (2007, p. 178), "most governments still share the main elements of traditional system of public administration".

As mentioned previously (section 2.3.2), legislation governing functions of the CS is a common trait of the modern civil service. Principles and operational features of a CS can be defined by a written code, at times in constitutions with operational practices in regulations or ordinances. The CS is usually defined by emphasising its

\footnotetext{
${ }^{14}$ Refer to section 2.3.4.
} 
functions, methods of appointment, or legal status. With legislation (including secondary legislation that sets out normative legal rules that are enforceable as law) as the core for describing the CS model in this thesis, the focus is on the legal aspect. In general terms, such legislation is aimed:

to provide a legal framework for the establishment and development of a state civil service which is politically neutral but designed to provide efficient and cost effective administrative support services to the elected government in the achievement of its economic and social objectives. (Collins, 1993, p. 331)

Cardona (2002, p. 2) explains that laws governing the CS are public laws which define "responsibilities, liabilities, duties and rights of those who execute the powers of the state, manage public funds or provide the services of the state to the public." A CS Act can be considered to be an instrument subservient to a range of policies which can be either positive or negative in effect. Negative objectives are intended to avert a number of undesired consequences such as politicisation of the CS, corruption, patronage, and nepotism. Although a wide range of models on which the CS Acts are based is evident in different countries (Choi \& Whitford, 2011), generally, CS legislation is based on similar policy lines.

Different countries enact the CS legislation for different purposes. Therefore, what is included in such legislation can vary considerably. The OECD (1996, p. 6) has identified four "best practice" objectives for CS legislation:

a) raise the professional quality of staff so as to improve performance, grant a certain degree of independence for those staff executing public powers in order to prevent political abuse and other mismanagement, and foster appropriate ethical standards in public administration;

b) enable the government to adapt the administration to changed needs, e.g. to restructure, to cut costs, or to reallocate human resources from one part of the civil service to another;

c) give the public administration legitimacy in the eyes of the citizenry, and make citizens and other groups of state employees accept the features underlying a professional civil service (providing a balance between 
qualitative requirements and duties on the one hand and rights and benefits on the other); and

d) render a career in the civil service attractive, and to retain people in that career.

Management of the CS by a statutory commission independent of the executive has been a common feature of much CS legislation, beginning in Europe (see section 2.3.2). Nevertheless, the principle of regulating the CS by an independent body rather than through direct authority of the political arm of the executive power is the subject of a debate that has lasted for over a century. In reference to models of independent civil services, Argyriades (1996, p. 65) states that "governments have grown increasingly wary of such grands corps d'état that are removed from their control and able to exercise a measure of independent influence, often commensurate with the quality of their professional advice". It is increasingly argued that "executive leaders, needing to consider their own re-election, their prestige, and their performance, feel a need to gain control of the instruments of governance" (Suleiman, 2003, p. 214). However, during the admission of Central and Eastern European (CEE) countries into the EU, those countries had to pass legislation to establish neutral and professional civil services (Neshkova \& Kostadinova, 2012, p. 326). Regarding this, Dimitrova (2005, p. 81) states that the EU under its administrative conditionality required countries to pass:

legislation establishing civil services in the CEE candidates as independent professional bodies and protecting civil servants from dismissals and extensive political interference. The model endorsed by the administrative conditionality requirements is thus closest to the classical Weberian bureaucracy model, although some subsequent advice related to the adoption of performanceoriented criteria in personnel policy brings it closer to NPM [New Public Management] and therefore, according to some, it is a mixed model. ${ }^{15}$

\footnotetext{
${ }^{15}$ See Fournier (1998) who evaluates it as a classic Weberian model and Bossaert and Demmke (2003) who disagree, calling it a mixed model.
} 
The diversity of the constitutional framework in different countries does not allow the creation of a single blueprint for the relationship between the political arm and the administrative arm of the executive. In reference to the Commonwealth countries, Sharpe (1993, p. 219) notes that "although each government has to finetune the details to fit its own particular circumstances, the principle of maintaining the neutrality of the civil service seems to be common" (also see section 2.3.15). Additionally, the OECD (1999, p. 11) has emphasised that whichever model is chosen, it is "necessary to strike a balance between the value of independence and that of loyalty to the lawfully ruling government". Such a balance is often achieved by striking a bargain between political arm and the administrative arm of the executive. For instance, politicians give up the right to interfere in personnel management functions or to direct civil servants on matters of administration, while civil servants give up the right to blame or express political opposition to the ruling regime (Hood \& Lodge, 2006, p. 7).

A relative separation between the political and administrative arms of the executive is a common feature in modern constitutional democracies (see section 2.4.1). Complying with the lawful orders of the elected government of the day continues to be the basic statutory responsibility of the administrative arm. As discussed later (sections 2.4.1 to 2.4.3), however, an absolute demarcation between the two arms may not be possible and, particularly in emerging democracies, there may be continuing tension over where the boundary lies. There is further detailed discussion of the interface between politics and administration as it affects the CS in section 2.4.1.

\subsubsection{Components of civil service model.}

Studying a CS system ${ }^{16}$ involves identifying its attributes or properties. In this regard, Morgan and Perry (1988) state that the study of a CS system should include at least four parameters: rules, structures, roles, and norms. According to Morgan and Perry (1988, p. 89), while "rules" mean the "assigned guides for conduct (Jackson, 1987) or constraints that social systems use to structure behavior (Ostrom,

\footnotetext{
${ }^{16}$ See section 1.5.2.
} 
1985)", "structures represent the organizational arrangements of civil service systems". Furthermore, as "roles reflect the set of activities expected of a person occupying a particular social position", "norms involve values internal to the system which ground the rules and roles" (Morgan \& Perry, 1988, p. 89).

As mentioned earlier (section 2.3.2), with the evolution of a contemporary CS, the norms and principles of the CS have also been evolving. More importantly, there are no universally accepted principles regarded as being necessary for a CS. However, Bossaert, Demmke, Nomden, and Polet (2001) have listed typical elements of career models and typical elements of models with other structural characteristics. This is presented in table 2.1 .

Table 2.1: Typical elements of a classical career model and model with other structural characteristics

\begin{tabular}{|l|l|}
\hline Career model & Model with other structural characteristics \\
\hline Recruitment only to entry-level positions & $\begin{array}{l}\text { Recruitment to posts at all levels of the } \\
\text { profession }\end{array}$ \\
\hline $\begin{array}{l}\text { Specific requirements } \\
\text { (diplomas/qualifications) for specific careers }\end{array}$ & $\begin{array}{l}\text { Specific skills set as requirements for } \\
\text { specific posts }\end{array}$ \\
\hline Maximum age limits for recruitment & No maximum age limits \\
\hline $\begin{array}{l}\text { No recognition of professional experience } \\
\text { outside the public sector }\end{array}$ & $\begin{array}{l}\text { Recognition for previous professional } \\
\text { experience }\end{array}$ \\
\hline Statutory remuneration scheme & Differentiated and/or individual rates of pay \\
\hline $\begin{array}{l}\text { Automatic increases in salary based on } \\
\text { seniority }\end{array}$ & No automatic increases in pay \\
\hline Statutory promotion system & No set promotion system \\
\hline Permanent tenure & No permanent tenure guarantee \\
\hline Special statutory pension scheme & Non-statutory pension scheme \\
\hline Special disciplinary legislation & Different patterns of disciplinary legislation \\
\hline
\end{tabular}

Source: Bossaert, et al. (2001, pp. 82-3)

Although CS systems vary between nations, Butler (1993, p. 396) has identified the following core characteristics of the traditional British Civil Service as being the common features of a classical Weberian bureaucracy: 
a) a permanent civil service recruited by competitive examination, and promotion by merit, rather than by patronage or political affiliation;

b) a division between intellectual and mechanical work;

c) clear separation of tenure, functions and responsibilities between civil servants and politicians (that is ministers);

d) high standards of integrity based on a clear separation between public duty and private interest;

e) an expectation that civil servants be employed within the civil service until retirement, subject to adequate performance;

f) a substantial degree of horizontal coherence across the service, including common terms and conditions between departments, controlled as part of government expenditure by the Treasury.

The above features, predominantly belonging to the "classical model", can be present to varying degrees in modern day civil services. This thesis combines the above characteristics with a number of other aspects present in contemporary CS legislation (including Acts and regulations) to present the main components of the CS models. In Chapter Six, while presenting the Maldivian CS model, an assessment is made on what "classical" features are retained and which have shifted from the classical model.

The CS models are commonly described and compared under the following headings:
a) Legal basis of civil service
b) Scope of civil service
c) Management of civil service
d) Code of conduct
e) Categories of civil servants
f) Merit system
g) Recruitment system
h) Classification system
i) Salary and reward
j) Promotion system 
k) Political rights and neutrality

1) Employment rights and protection

m) Disciplinary procedures

n) Grievance procedures

o) Pension and retirement

The following sections provide a brief overview of each of the above components. In the discussion, references to practices from different nations are given. How some of these components co-exist within a democratic environment and the particular question of the relationship between politics and administration is discussed in detail later in this chapter (see section 2.4).

\subsubsection{Legal basis of civil service.}

The legal framework for the CS or public service varies from country to country. However, The Committee of Minister of Council of Europe [CoE] (2000) has recommended that as a minimum requirement, "the legal framework and general principles concerning the status of public officials should be established by law or collective agreements and their implementation should be left to the government and/or other competent authorities or settled through collective agreements". In this respect, provision for the CS can be codified in a number of documents. They include:

a) Constitution;

b) Acts (including public law and private law); and

c) Secondary legislation (legislation made by government or an executive body that is vested with power to issue instruments such as decrees, directives, regulations, rules, orders, and so forth).

\subsubsection{Scope of civil service.}

Scope of the CS is concerned with identifying the parameters of the CS. Defining scope of the CS is important in order to determine the forms of public employment in the CS and other institutions of the state. In most countries a number of state institutions are often not included within scope of the CS. As a result, careful 
consideration is needed in defining scope of the CS. Cardona (2001, p. 5) identifies three main types of scope:

Vertical scope - where to draw the upper dividing line between politics and administration and the lower dividing line between civil servants and other public employees?

Horizontal scope - what public organisations are to be included within the civil service law and what organisations have to have specific statutes or can simply be regulated by general labour law?

Material scope - what other aspects of civil service employment such as pensions, working hours or holidays can be regulated by more general labour laws?

\subsubsection{Management of civil service.}

Management of the CS is linked to the responsibilities of the state as the employer of civil servants. Common standards of human resource management throughout the CS are required to maintain uniformity. However, the manner in which a nation structures these responsibilities can vary considerably. As Trendafilova (2008, p. 2) states, "there is a different mix of institutional players in different countries charged with the management of civil services". Trendafilova (2008, pp. 2-4) clarifies that the management function involves the interaction among three institutional actors: (1) a central management capacity that is usually part of the executive charged with the responsibility of the overall management issues ${ }^{17}$ such as proposing legislation and personnel policies, monitoring of rules and policies, and management of $\operatorname{training}^{18}$; (2) an independent civil service commission that at times acts as a regulatory body or ensures that personnel management functions are implemented in a fair, open manner and on merit principles; and (3) individual ministries whose minimum responsibilities include initiation of recruitment and selection or initiation of salary increases in centralised civil service systems.

\footnotetext{
${ }^{17} \mathrm{CoE}$ (2000) also recommends that, "the management policies relating to public officials should, in general be the responsibility of the government".

${ }^{18}$ According to Euroconsult Mott MacDonald (2008, p. 21), the functions that such a central authority often carries out include, "position creation and classification; staff training and professional development; specification of terms and conditions of employment; drafting of disciplinary codes; and specification of salaries and benefits".
} 
The extent of the centralisation of personnel management function is also an important aspect. A centralised system of the CS management does not necessarily imply "a single, central monolithic organ controlling all system personnel movements, but rather some degree of shared personnel authority exercised by several entities at the central level" (Nunberg, 1992, p. 15). The powers in a central system could be divided among the different bodies mentioned above. Regardless of how the functions are divided the model promotes central supervision of functions. On the other hand, a decentralised system of the CS management "increases the decisional autonomy of line managers on most personnel matters, leaving only broad policy guidelines to be worked out at the center" (Nunberg, 1992, p. 16). Increasingly governments are moving away from "centrally-managed career-based civil service systems towards decentralised management of human resources" (Laking, 2007, p. 5) thereby fragmenting the uniform code of the CS.

\subsubsection{Code of conduct.}

A written code of conduct or a labour code is a feature of many CS and often outlines the main duties of the civil servants. As indicated earlier (section 2.3.3), principles and operational features of a CS can also be defined by such a code. While the constitution lays the general outline, operational practices are defined in regulations or ordinances. In the past, such secondary legislation covered detailed behaviours that were expected from civil servants. This is changing as countries increasingly find such an approach to be inconsistent with effective human resource management, focusing more on normative principles of behaviour and performance standards (OECD, 1997b). However, use of a code of conduct containing the basic professional values expected of an independent CS is still common practice. Furthermore, a code will "generally leave considerable room for individual solutions adapted to the individual circumstances and, where necessary, for departure from its provisions if other considerations demand" (OECD, 1997b, p. 5).

\subsubsection{Categories of civil servants.}

Categories of civil servants can vary depending on the CS model the nation adopts. The important point is that the categories and levels of civil servants should be 
identified based on the functions performed to which a pre-defined responsibility is attached. In this regard, creation of a senior CS as a distinct category of the CS is seen in a number of nations. A senior CS often involves "an elite, professionalized, service-wide corps" (Nunberg, 1992, p. 26) that is offered more attractive incentives and conditions compared to the general civil servants. This elite corps is mostly created to combat such problems as:

a) Wage erosion in comparison with the private sector and wage compression in relation to lower civil service echelons;

b) Increasing marginalization of higher civil service cadres from policy and political decision makers because of the former's perceived lack of responsiveness to political agendas;

c) The absence of a public-spirited, interagency, service-wide corps or elite cadre; and

d) Difficulty in attracting highly qualified professionals away from the private market. (Nunberg, 1995, p. 27)

The decline of permanent tenure for civil servants has also increased contractual employment within the CS. It is believed that contractual employment for a limited period potentially attracts a larger pool of candidates for a job.

\subsubsection{Merit system.}

Since the time of its consideration in the 1854 Northcote/Trevelyan Report, the meaning of "merit" has evolved through legislation, case law, and societal interests. During this time, the concept of merit has also been in contention with patronage appointments. Despite the fact that most governments continue to use principles other than merit to at least some extent, they still consider merit to be an important principle for the majority of positions in the CS.

Disagreement continues about what constitutes merit, which is only vaguely defined in some systems. Nonetheless, with merit recruitment being one of the defining characteristics of Weber's model of bureaucracy (Page, 1992), and civil servants being selected on the "basis of achievement criteria and merit, rather than ascriptive 
criteria such as case, race, class or language" (Peters, 2010, p. 83), this principle is retained even with modern changes in the CS.

Stahl (1962, p. 28) defines merit broadly as "a personnel system in which comparative merit or achievement governs each individual's selection and progress in the service and in which the conditions and rewards of performance contribute to competency and continuity of service" (cited in Nigro, 2006, p. 4). Furthermore, in a careful attempt to define what merit connotes, the Australian Public Service Act (1999) provides a "test" in identifying a decision based on merit. It specifies that a decision relating to engagement or promotion is based on merit if:

a) an assessment is made of the relative suitability of the candidates for the duties, using a competitive selection process; and

b) the assessment is based on the relationship between the candidates' workrelated qualities and the work-related qualities genuinely required for the duties; and

c) the assessment focuses on the relative capacity of the candidates to achieve outcomes related to the duties; and

d) the assessment is the primary consideration in making the decision.

\subsubsection{Recruitment system.}

A common principle of civil services is that entry will be by fair and open competition for specific positions, with selection based on merit. Civil services are, however, distinguished by the levels at which entry can occur. Recruitment systems are often classified into two general types:

a) Closed-entry, hierarchical systems with limited inter-class (and often interdepartmental) mobility and highly selective entry requirements (Nunberg, 1992, p. 21). Entry is generally restricted to a small range of lower level position.

b) Open systems with lateral (and more flexible) entry, greater vertical and sometimes horizontal mobility, and more frequent use of short-term or 
contractual employment (Euroconsult Mott MacDonald, 2008). Entry is generally possible at all levels.

It might be difficult to place a nation exactly into one of the above ideal typologies because most countries operate in between these extremes. To ensure recruitment based on merit, a regulated and standardised entrance examination has also been commonly used in civil services to promote fair and equal treatment of the CS candidates (Meyer-Sahling, 2009, p. 27). With the changing face of civil services, however, use of standardised examination systems is on the decline (Meyer-Sahling, 2009). Nonetheless, eight features commonly found in recruitment within AngloAmerican civil services are given below:

a) Conduct a job analysis leading to a written statement of duties (the job description) and the knowledge and skills which the job holder will need (the person specification)

b) Distribute and disseminate a job advertisement (i.e. vacancy announcement) to eligible groups and applicant. Include a summary of the job analysis with the vacancy announcement when possible.

c) Draft (or use) a standard application form.

d) Develop and use a scoring scheme based on the person specification (i.e. the pre-specified criteria against which candidates will be judged and hiring decisions made).

e) Define and implement a short-listing procedure to reduce applications, if necessary, to a manageable number.

f) Develop a final selection procedure based, again, on the person specification. Where possible and appropriate, finalists should be interviewed and evaluated by a panel.

g) Identify and appoint the "best" candidate based on the scoring scheme.

h) Notify both successful and unsuccessful candidate(s) of results. (Euroconsult Mott MacDonald, 2008) 


\subsubsection{Classification system.}

An individual's job that includes duties and responsibilities can be referred as a position, and "clusters of positions with similar characteristics are organized into what is called a job classification" (Berman, Bowman, West, \& Van Wart, 2006, p. 128). According to Shafritz (1973, p. 3), in such classification systems, formal job descriptions of all the jobs in the organisation are organised "into classes on the basis of duties and responsibilities for the purpose of delineating authority, establishing chains of command, and providing equitable salary scales".

In general, classification systems can be grouped into two main types: rank-in-job and rank-in-person. In the former, rank and salary are determined by the job that one holds, and promotion ${ }^{19}$ is generally achieved by applying for a higher-graded position in competition with others (Berman et al., 2006, pp. 123). In a rank-inperson system, individuals are promoted to higher grades based on their potential and then become eligible for jobs matching their higher grading.

Job classification is a necessary element in both rank-in-job and rank-in-person systems because it supports assessment of candidates' suitability for specific positions. As Lam and Chan (1995, p. 1320) state, job classifications "provide the bases to develop testing and other screening devices, such as the pre-established criteria to determine the employee's relative qualification and performance". In this regard, Nunberg (1992, p. 30) identifies four main features of the traditional methods used to classify civil servants:

a) Classify positions according to differences in job duties and corresponding responsibilities. The positions are ranked and arranged into occupational groups;

b) Each occupational group has a unified salary schedule. This is determined by a central personnel authority. There is a flat salary for each grade. Each grade contains a number of incremental steps;

${ }^{19}$ Also refer to section 2.3.14. 
c) Civil servants advance to the next incremental step based solely on length of service. Civil servants have job tenure and progress through the incremental steps automatically; and

d) Recommendations for service-wide salary adjustments to grades are normally carried out annually.

It is important to note that such traditional features are seldom used in their strictest sense. In most countries, they are mixed with the alternative structural characteristics mentioned in table 2.1. For instance, promotions are often based on a performance assessment in addition to the length of service.

\subsubsection{Salary and reward.}

According to OECD (1997a), remuneration systems aim to reconcile two imperatives: to maintain overall budgetary equilibrium and to motivate officials. In traditional civil services, remuneration is based on centrally determined standards with little room for flexibility at organisational level (Nunberg, 1995, p. 31). Such systems rely "mainly on unified pay scales with automatic, fixed step increments based on seniority and determined on a service-wide basis" (Nunberg, 1995, p. 31). Relatively strict establishment control ${ }^{20}$ is a feature in traditional civil services.

Compensation for civil servants is normally composed of several components. Generally they fall under immediate reward or deferred reward. Such rewards can also be classified as tangible rewards that can be monetarily valued or intangible rewards associated with intrinsic motivation. Mukherjee and Manning (2000) summarised the different types of incentives that can be allocated for civil servants (table 2.2).

\footnotetext{
20 "Establishment control refers to the set of institutional arrangements used by governments to ensure that an appropriate number of staff with the right mix of skills are hired at the correct grades" (Euroconsult Mott MacDonald, 2008, p. 65).
} 
Table 2.2: Incentives for civil servants

\begin{tabular}{|c|c|c|c|c|}
\hline & & \multicolumn{2}{|c|}{ Contractually-provided } & \multirow{2}{*}{$\begin{array}{l}\text { Non-contractual/ } \\
\text { intangible }\end{array}$} \\
\hline & & monetary & in-kind & \\
\hline \multirow[t]{2}{*}{ Current rewards } & base rewards & 1. base wage/salary & 2. health insurance & $\begin{array}{l}\text { 3. job security, } \\
\text { prestige, social } \\
\text { privileges }\end{array}$ \\
\hline & allowances & $\begin{array}{l}\text { 4. transportation, } \\
\text { housing, meals, } \\
\text { telephone, travel, } \\
\text { cost-of-living }\end{array}$ & $\begin{array}{l}\text { 5. transportation, } \\
\text { housing, meals, } \\
\text { travel }\end{array}$ & $\begin{array}{l}\text { 6. trips abroad, } \\
\text { training }\end{array}$ \\
\hline $\begin{array}{l}\text { Future } \\
\text { expectations }\end{array}$ & & 7. pension & $\begin{array}{l}\text { 8. housing, land, } \\
\text { etc. }\end{array}$ & $\begin{array}{l}\text { 9.reputation, } \\
\text { re-employment } \\
\text { after retirement }\end{array}$ \\
\hline
\end{tabular}

Source: Mukherjee and Manning (2000)

\subsubsection{Promotion system.}

Promotion is also a fundamental component of any CS model. There are two broad approaches to promotion depending on the type of the CS model. They are:

a) In career systems, candidates will be assessed on their general potential for higher management and policy positions and if successful move into a selection pool from where they can be assigned to specific posts requiring these skills;

b) In position-based systems, applicants will be appointed to a specific post and have to demonstrate that they have the competencies required for the post these requirements are likely to be based in part on generic management and policy experience and aptitude, but may also give weight to experience in the specific policy or operational requirements of the post. (Laking, 2007, p. 41)

The assumption is that in career systems the "officials should not be promoted to a higher grade unless they are judged capable of filling the entire range of posts associated with that grade" (Ridley, 1983, p. 190). On the other hand, generally in position-based systems, apart from some positions that require specific professional 
qualifications, "the higher the position, the more general management abilities are emphasised rather than specific experience in the organisation" (Laking, 2007, p. 41). Once again, it is important to highlight that most countries fall in between these two extremes and therefore often use a combination of these features.

\subsubsection{Political rights and neutrality.}

With change of governments an accepted norm in a modern democracy, civil servants must be willing to serve the elected government of the day, whatever that government might be. As a result civil servants are required to be unbiased and politically neutral in undertaking their duties and responsibilities: they "should avoid activities likely to impair or to seem to impair, their political impartiality or the political impartiality of the public service" (Kernaghan \& Langford, 1990, p. 56). In order to maintain a neutral CS therefore, a number of rights at the disposal of the general public may be constrained for civil servants.

Generally, political rights refer to political activity ${ }^{21}$ and engagement in public comment. ${ }^{22}$ As far as political rights of the civil or public servant are concerned, one argument is that:

public servants should enjoy as many political rights as other citizens; this right clashes, however, with another legitimate right - the right of public officials and members of the public to enjoy the reality and the perception of impartial public service. (Kernaghan \& Langford, 1990, p. 61)

\footnotetext{
21 "Political activity encompasses the rights to vote in any election; to seek election to public office; to be a member of a political party or organization; to hold an office in a political party or organization; to attend political meetings, rallies and conventions; to speak in support of or in opposition to a particular candidate at political meetings, rallies or conventions; to serve as a delegate or alternate to a political party convention; and to campaign for or against a political party or candidate by such means as making a financial contribution, soliciting financial or other contributions, canvassing door-todoor, working at the polls in a partisan capacity, transporting voters to the polls on behalf of a political party or candidate, distributing campaign material, wearing political badges, and displaying lawn signs" (Kernaghan, 1986, pp. 639-40).

22 "The right to engage in public comment is the right to speak in public on matters of political controversy or on issues of government policy or administration" (Kernaghan, 1986, p. 640).
} 
Proponents of unlimited political rights to civil servants argue that limiting the rights excludes some of the most educated citizens in the labour force from political activity and such restrictions do not necessarily suppress the political views of those individuals. The counter argument is that restrictions placed on civil servants and public servants "are reasonable limits in a free and democratic society" (Kernaghan \& Langford, 1990, p. 62) and political rights "should only be lawfully restricted in so far as it is necessary for the proper exercise of their public function" (CoE, 2000).

As Vaughn (1976, p. 8-4) observes, the debate concerning the appropriateness of restrictions on political activities has been intense and the propriety of such restrictions is open to considerable debate. However, according to Mosher (1982, p. 23), such deprivations of civil servants' rights are justified to assure the continuing viability of the democratic system. Basic rights such as freedom of association and expression, and rights to acquire wealth through enterprises related to the CS profession, can be restricted to ensure that civil servants maintain the integrity of the CS and also to eliminate abuse of power and conflict of interest issues. In order to maintain the professional ethos of the CS, restrictions on such rights are justified in a democratic society (Meyer-Sahling, 2009, p. 60). As far as political rights are concerned, a common belief is civil servants should be allowed to be members of political parties but should refrain from being politically active or manifesting their political views in public.

Those who believe restrictions should be in place argue that individuals who join the CS or public service should do so with a realisation that to maintain the political neutrality of the service, some restrictions on individual political rights will be in place. Hood and Lodge (2006) argue that both the politician and the public servant need to give up some of their rights, which they refer to as "public service bargains". Furthermore, some argue that expansion of political rights can lead to patronage appointments when ministers' confidence in the loyalty and impartiality of civil servants is absent (Kernaghan \& Langford, 1990, p. 63). Therefore, the challenge for any CS is to find the optimum balance between political rights and political neutrality. However, as Kernaghan (1986, p. 652) has correctly stated, "the perfect balance between political rights and political neutrality for public servants is likely to remain an elusive goal." Others argue that civil servants cannot be fully neutral and 
so the focus should be to "have loyal civil servants who are aware of ethical problems, the dangers of corruption and the problems involved with political favouritism" (Demmke, 2005, p, 63).

\subsubsection{Employment rights and protection.}

As mentioned previously (section 2.3.4), one of the key characteristic of the classical CS is the expectation that civil servants be employed within the civil service until retirement, subject to adequate performance. Although in some countries a CS career probably no longer holds the appeal it once possessed, it was traditionally considered as the epitome of success in many countries. In the past, civil servants who met minimum standards of performance and conduct were assured of tenure in their jobs until retirement. In career systems in particular, civil servants were protected from outside competition as far as promotion to higher levels was concerned. Furthermore, there were significant legal barriers to their dismissal. However, such features have changed significantly in many countries. In most OECD countries, the possibility of a job for life in public employment has declined considerably (OECD, 2004). Increasingly, performance is linked to the job. This departure from the classical career system has ensured that civil servants face growing competition from outside applicants during promotions. With such changing trends, governments increasingly use different mechanisms to make civil servants redundant.

Although the idea of a career for life may have eroded in some civil services, sufficient job protection is still considered an important condition of the CS in a modern constitutional democracy (OECD, 1999). Importantly, protection of civil servants "against political and managerial discretion over dismissal reduces civil servants' dependence on outside interests and enhances the prospects of civil service impartiality" (Meyer-Sahling, 2009, p. 38).

In the Weberian bureaucracy, a CS job was associated with holding a "vocation" and a "career" (Gerth \& Mills, 1948, pp. 198-204). Civil servants were expected to devote their professional careers to the CS. Thus, restrictions on civil servants undertaking additional employment are also a key feature in the classical Weberian CS model. According to Meyer-Sahling (2009, p. 60), restrictions placed on 
"economic activities of civil servants, notably alternative income opportunities in the private sector, are meant to increase the impartiality and fairness of civil servants towards society". However, in developing countries, civil servants commonly undertake additional employment in the private sector, primarily due to the relatively low pay in the CS jobs.

\subsubsection{Disciplinary procedures.}

Disciplinary actions are often the result of failure to fulfill the duties of the civil servant, whether intentionally or through negligence. The objective of having the provision for disciplinary actions in legislation is to make civil servants accountable to their superiors in accordance with the law. Normally, disciplinary provisions include definitions of specific misconduct and wrong-doing as well as the administrative penalties for such actions.

\subsubsection{Grievance procedures.}

A legal remedy for the protection of the rights of civil servants is a common provision in civil services. It could be either before a court or an independent institution. In general, individual rights to a defence and to challenge sanctions before an independent body are considered primary features that guarantee the objectivity of a grievance mechanism. In most cases, a two-tier system of hearing the complaint is favoured. Initially the complaint is examined by a direct superior or the agency head, followed by referral to a neutral and specialised committee or board (Aeberhard, 2001, p. 28). This may apply to individual grievances as well as group grievances. In the case of group grievances, recourse to strike action is also used at times.

\subsubsection{Pension and retirement.}

Provision of a pension is a further feature of the Weberian bureaucracy (Gerth \& Mills, 1948, p. 203). A pension right is part of a "bargain" between the state and the employee that usually includes some incentive - in the form of deferred benefits for the employee to provide loyal service over the whole of a career. Pension is often 
a continuous payment given at a defined rate, for life, typically upon retirement. Retirement age can vary across countries, often with a mandatory retirement age at which the person is entitled to the maximum possible pension, and early retirement options at which the person is entitled to a scaled back pension. The defined-rate retirement pension is often calculated based on the length of service and past salaries.

In the past where traditional career models of the CS existed, many countries had specially designed occupational pension schemes for civil servants (Bossaert et al., 2001, p. 163). However, with the changes in the economy and demography, many countries are reforming their pension schemes to make them more economically affordable for the entire community. Some countries have even scrapped specially designed schemes for civil servants and moved to general schemes. Other changes include moving from schemes that are paid out of the government budget to fully funded employer-employee contributing schemes, as well as changes in early and mandatory retirement ages. Such fiscally motivated changes have helped erode the idea of a job for life, particularly when pension rights are made portable.

\subsection{Linkages between civil service and democracy}

The previous sections (2.2 and 2.3) examined the democratisation process and the contemporary CS. This section links the two and outlines the role of the CS in a democratic setting.

This thesis focuses on the changing relationship between the political executive, which is the elected representatives of the citizens, and its administrative arm, the CS as an important element in a process of democratisation. It is however important to underline that democratisation is a process involving change in a wider range of public governance institutions. Conventionally these institutions include the formal constitutional components of legislature, executive and judiciary together with specific overseeing bodies and other laws and quasi-autonomous public bodies intended to constraint the power of the political executive. According to Carothers (2007) these constraints are basically from the "rule of law" buttressed by the various accountability institutions. Other informal institutions also include nongovernment watchdogs like civil society and the media. Although such watchdogs do 
not have the legal apparatus, they "in conjunction with conscientious journalists, highlight wrongful doings that otherwise would go unnoticed, and provide potential allies for state agencies that might want to undertake appropriate action" (O'Donnell, 1998, p. 122).

The formulation of a depoliticised and professional CS can however be a key generative mechanism in the new structure of relationships being created between the governors and the governed. This thesis shows that the Maldivian CS Act was not simply a shift of power relationships within the political executive and the CS, but it was a significant shift in the power structure of the state that intended to put constraints on the powers of the political executive as well as instil a neutral and competent CS that serves the people through their elected representatives. As such, the CS is held accountable beyond the political executive and thereby contributes to a broader shift in the governor-governed relationship (see section 2.4.1).

Democratic constitutions feature a chain of delegation from the citizens to their elected representatives. Civil servants implement the policies of these elected representatives whether in a presidential or parliamentary form of government. The chain of accountability runs in the reverse order where the civil servants are accountable to those elected representatives who in turn are accountable to the citizens (see section 2.2.3 - frail, unconsolidated democracies - for the nature of checks and balances among state institutions). In other words, civil servants are bureaucratically accountable to the elected officials, and elected officials are politically accountable to the voters (Hughes, 2012). Additionally, the legislature can also hold ministers as well as public officials accountable through the parliamentary select committee structures (Scott, 2000).

The CS as an ideal type is aimed not only at efficiency but also fairness in the sense of non-arbitrariness or more generally "the rule of law". Therefore, protecting the CS from the direct personalistic control of the political executive and making it accountable to the law is an important "generative" factor in democratisation because it is through administration that the political executive exercises its power. In summary: 1) democratisation involves moving a polity away from autocracy and towards democracy by institutional change aimed at having a framework of law 
ensuring rights, constraints on political executive to act according to the law, and strengthening the accountability institutions that will enforce those constraints; 2) CS is based on neutral competence as well as rule of law; 3) the main generative role of CS reform in democratisation is to contribute to the executive constraints by bringing executive action within the rule of law.

The rest of this section is divided into four parts. The first part examines the role of civil servants within a democratic environment. The second section demonstrates how politicians influence the CS settings. In the third section, possible challenges to the CS in the context of an emerging democracy are examined. The last section examines possible ways the CS contributes in the developmental aspect of the nation.

\subsubsection{What is the role of civil servants in a democracy?}

Unlike political office holders, civil servants are not elected officials. As a result questions have been asked about their legitimate role in the modern political system. As indicated previously (section 2.3.3), the traditional view is that the officials elected to political office control the executive function of the state which has "at its disposal a neutral civil service with a wealth of professional expertise, which prepares and implements public policy" (Christensen \& Lægreid, 2004, p. 10) based on the agenda of the government in power; and that civil servants "accept the authority of the government, and work as best they can to carry out the government's programme in office, within the law" (Prebble, 2010, p. 54). It is also the general notion that the CS will be provided relative autonomy from the elected officials in matters of employment but will be accountable to the law and beyond the political executive to the institutions of accountability such as the courts and the legislature. This is a bargain between the factions competing for political power that enables them to have an efficient and loyal CS at their command if and when they win an election.

In this model of CS, therefore, it is assumed that there will be a clear demarcation between political choice (the domain of the political executive) and administration (the domain of the CS). The OECD (1997a, p. 8) suggests there "is a separation 
between political and administrative levels, and the absence of interference in the form of partisan concerns in the management of careers". The assumption is that politics and administration "although closely interdependent, are different in nature, have a different underlying logic, and have different sources of legitimacy" (OECD, 1999, p. 21). As with OECD documents cited here, principles for a relatively clear formal separation between politics and administration and a politically neutral CS are still frequently set out to be important elements in a modern CS.

Outlining an ideal situation, Ridley (1995) states that the place of the CS in a democratic state can be explained using three simplified models. Firstly, civil servants are considered the servants of a democratically elected government that needs to answer to its democratically elected parliament in relation to the administration of its policies. Secondly, there is need for a separation of policymaking and implementation, ensuring that policy-making is the function of the elected officials while the implementation rests with the civil servants. The third model sees the CS "as having an independent view of the national interest above party politics and above sectional interests", where, in addition to the democratically elected government, civil servants have a responsibility to the state, the law, national interest or common welfare (Ridley, 1995, p. 15).

Thus, the principles in play in the three models of Ridley (1995) are: (1) civil servants are loyal servants of the elected government with no separate political identity; (2) civil servants' roles are confined to the implementation of policy determined by the politicians; and (3) civil servants are answerable to national values that can be beyond the authority of the government. As changes of government are unavoidable in democratic societies, such interests beyond party politics can be essential for the progress and development of the nation.

Kernaghan (1976, p. 433) identifies the following characteristics for a truly neutral public service in a Westminster-style government:

a) Politics and policy are separated from administration. Thus, politicians make policy decisions; public servants execute these decisions; 
b) Public servants are appointed and promoted on the basis of merit rather than on the basis of party affiliation or contributions;

c) Public servants do not engage in partisan political activities;

d) Public servants do not express publicly their personal views on government policies or administration;

e) Public servants provide forthright and objective advice to their political masters in private and in confidence. In return, political executives protect the anonymity of public servants by publicly accepting responsibility for departmental decisions; [and]

f) Public servants execute policy decisions loyally and zealously irrespective of the philosophy and programs of the party in power and regardless of their personal opinions. As a result, public servants enjoy security of tenure during good behaviour and satisfactory performance.

The first of Kernaghan's principles, that politics and administration are separate domains, associated with the writing of Max Weber and Woodrow Wilson over a century ago, have been widely challenged ever since. Politicians believe that their policy objectives are frustrated by civil servants imposing their own preferences over the wishes of the elected representatives of the people, and civil servants that politicians have unrealistic expectations for their policy objectives or are meddling in matters of administration (Aberbach, Putnam, \& Rockman, 1981, cited in C. Campbell \& Peters, 1988). As a result, each will attempt to influence the other's "domain" and therefore politics and administration "may not be readily separable" (C. Campbell \& Peters, 1988, p. 82).

In arguing that the line between the two domains is blurred, the basic assumption is that political executives and the permanent CS each have distinct values and interests and will use the power and authority they have to achieve their different objectives. Civil servants for example "cannot be portrayed as apolitical eunuchs" (Kingdom, 1990, p. 3) and may use their control of the administrative apparatus and information about operations to influence the policy process or to shape actual policy execution. Alternatively, when politicians want to have a greater input in matters of public employment or when they perceive apparent resistance from civil servants, they can use their authority to create alternative sources of policy advice and alternative 
modes of service provision (C. Campbell \& Peters, 1988; Aberbach \& Rockman, 1988).

The result of this dynamic may be a more or less stable realignment of roles between political executive and administrators or it may be a continuing source of mistrust and tension. C. Campbell and Peters (1988, p. 81) suggest that the tension is likely to be highest when governments change and "politicians .... find the civil service to be a convenient scapegoat for all the problems they have encountered" or the bureaucracy may "dig in its heels at administering a program they consider to be fundamentally flawed". These clashes and new accommodations do not mean that the zone between politics and administration is meaningless, however, only that it can remain contested territory subject to competing objectives and strategies. Some of the consequences of this dynamic are discussed in the following sections.

\subsubsection{How do politicians influence civil service?}

In a democracy winners of elections are able to place political appointees in positions in the country's bureaucracy. Such appointees are required to share the environment and to work with career civil servants. Nonetheless, the political masters have at their disposal mechanisms they can use to influence the administrative arm. One of them is politicisation of the CS. Aberbach and Rockman (1987) refer to politicisation as "the levels and types of political activity undertaken by civil servants, as well as to attempts by others to politically influence the behaviour of civil servants" (cited in Hojnacki, 1996, p. 137).

Politicisation can be applied in various forms. According to Hojnacki (1996) politicisation can be internally-driven, society-driven, or politician-driven. In simple terms, internal-driven politicisation is related to "political activities engaged in by civil servants themselves" (Hojnacki, 1996, p. 139). Society-driven politicisation can be considered as influences from societal groups who "lobby" or influence the decision-making process within the CS (Riggs, 1988). Arguably the most common type of politicisation, politician-driven politicisation occurs when "elected and politically appointed public officials have their own political agendas and often look to civil servants to help achieve them" (Hojnacki, 1996, p. 142). In other words, the 
political executive influences the administrative arm of the executive. Furthermore, such politicians attempt to control the behaviour of government organisations by introducing complex mechanisms for administrative procedures and oversights (Aberbach, 1990; McCubbins, Noll, \& Weingast, 1987; Meier, 1987; Miller \& Moe, 1983; Moon \& Ingraham, 1998). As such acts are arguably present in most countries, it can be argued that politicisation of the CS is evident in both developed and developing countries, although in different forms.

Recent research has supported this view (Meyer-Sahling, 2008; OECD, 1997a; Page \& Wright, 1999; Peters \& Pierre, 2004). According to Peters (2003) and Halligan (2007), political appointments are increasing even in Anglo-American countries, a concept that Light (1995) refers to as the "thickening" of government (also see Ingraham, Thompson, \& Eisenberg, 1995). Executives often find means to appoint political representatives for various oversight functions, and also to functions that are already undertaken directly by civil servants, creating duplications. One such approach is the appointment of political advisers, which Eichbaum and Shaw (2010) argue have raised concerns in some countries. Such developments have put considerable pressure on the neutrality of the CS even in developed countries (Peters, 2003, p. 18). In an attempt to identify different modes of politicisation by the approach a new government chooses to exert its control on the bureaucracy, MeyerSahling (2008) has proposed the following analytical tool in order to classify different approaches regarding politicisation of senior bureaucrats (table 2.3).

As the table shows, the level of politicisation can vary from a complete revamp of the top CS to use of already existing top bureaucrats. In this regard, a new government may choose to either: (1) retain the existing senior bureaucrats, and when a vacancy arises, promote lower ranked officials based on professional competence (non-politicisation); (2) replace senior bureaucrats by promoting lower ranked officials based on political affiliation (bounded politicisation); (3) replace senior bureaucrats by appointing officials from outside organs such as the private sector, academia, nongovernmental organisations or interest groups, based on political affiliation (open politicisation); or (4) replace senior bureaucrats by appointing personnel associated with the political party in power (partisan politicisation) (Meyer-Sahling, 2008, pp. 4-9). 
Table 2.3: Four ideal modes of politicisation

\begin{tabular}{|c|c|c|c|c|}
\hline & $\begin{array}{l}\text { Non- } \\
\text { politicisation }\end{array}$ & $\begin{array}{l}\text { Bounded } \\
\text { politicisation }\end{array}$ & $\begin{array}{l}\text { Open } \\
\text { politicisation }\end{array}$ & $\begin{array}{l}\text { Partisan } \\
\text { politicisation }\end{array}$ \\
\hline $\begin{array}{l}\text { The approach of } \\
\text { new government } \\
\text { towards inherited } \\
\text { senior bureaucrats }\end{array}$ & Do not replace & Replace & Replace & Replace \\
\hline $\begin{array}{l}\text { The career path of } \\
\text { new senior } \\
\text { bureaucrats }\end{array}$ & $\begin{array}{l}\text { Promote lower } \\
\text { ranks officials } \\
\text { from existing } \\
\text { bureaucracy, } \\
\text { based on } \\
\text { professional } \\
\text { competence }\end{array}$ & $\begin{array}{l}\text { Promote lower } \\
\text { ranks officials } \\
\text { from existing } \\
\text { bureaucracy, } \\
\text { based on } \\
\text { political } \\
\text { affiliation }\end{array}$ & $\begin{array}{l}\text { Recruit } \\
\text { outsiders from } \\
\text { non-political } \\
\text { settings, based } \\
\text { on political } \\
\text { affiliation }\end{array}$ & $\begin{array}{l}\text { Recruit } \\
\text { outsiders from } \\
\text { political } \\
\text { settings }\end{array}$ \\
\hline
\end{tabular}

Note: Modified based on Meyer-Sahling (2008, p. 8).

No matter the level of politicisation present, relations between politicians and bureaucrats are very significant and, as stated previously (section 2.4.1), one of the intended objectives of a politically neutral CS is to maintain a separation between politics and administration. In this regard, as mentioned previously (section 2.3.15), an integral component of the traditional model of political neutrality is for public servants to refrain from publicly expressing their personal views on government policies of administration, mainly to preserve the confidence of the public and of political masters in the impartiality of public servants (Kernaghan, 1976). The delicate line between bureaucracy and politics means that, in its strictest sense, if public servants openly support and defend the politicians in power and the government's policies, then the opposition will see it as collusion, but if public servants openly support the opposition and criticise the government, then the government suspects treason (Caiden, 1996). Mistrust can also occur between the civil servants and the politicians simply because on the one hand, civil servants have to loyally implement government policies and may therefore be seen as willing tools of politicians; and on the other may give critical advice about the feasibility of policies which, even if privately given, leads to accusations from the politicians of disloyalty. Perhaps that is why Wood and Waterman (1994, p. 13) have highlighted that the role politics plays within administration is one of the long-standing and 
continuing controversies evident in the field of political science and public administration. A clear demarcation between politics and administration may never be possible. However, as Jenei and Zupko (2001, p. 80) argue, although tension inevitably exists between politicians and civil servants, "a high level of cooperation is needed for the government to be effective".

In one respect, cooperation between administrators and politicians can be considered to be healthy as well. This is because as Part (1990, p. 107) has stressed, in order to serve the government elected by the people, it may be necessary for the bureaucracy to assume the coloration of the party in power, at least to some degree (cited in Barberis, 1997, p. 153). In some countries with a history of the CS, when a change in government occurs, senior civil servants are also expected to demonstrate to their new political leaders that they understand the new government's policy priorities and are prepared to provide professional advice on how to implement those policies. However, as Meyer-Sahling (2004, p. 77) notes, whenever there is a change of government, there will be at least some level of distrust between the incoming government and the bureaucrats it "inherits". A study conducted by the OECD (2007) also found that relations between political advisers and civil servants tend to be problematic in most EU and OECD member countries; particularly evident during the transition of governments (also see Eichbaum \& Shaw, 2010). ${ }^{23}$ The fears held by both sides will be visible, but these need to be put aside in order to maintain the integrity and professionalism of the permanent CS. How the transition of power takes place and whether it occurs in an organised fashion will be an indicator in determining whether the CS is operating as intended.

Unlike civil servants who are appointed based on merit, political appointees are appointed on the basis of their political affiliation. For political executives without prior experience in the public sector, there can be a "lack of management experience; lack of understanding of, and experience in, the public sector; and/or inadequate understanding of the programs and policies for which the political executive is

\footnotetext{
23 Some countries such as the Netherlands and Belgium have to manage for extended periods of transition where an election does not produce a clear majority party or coalition. Thus they have to have elaborate codes for civil servants to carry on with the necessary business of government during these periods. There are rules in New Zealand for such transitions, put in place following the introduction of mixed-member proportional (MMP) voting system.
} 
responsible" (Ingraham, 1987, p. 426). Some even argue that such appointees are on the whole more likely to be less competent and less experienced than career public servants (Kernaghan, 1976). Albeit that it is not the case with all political appointees, any lack of competence, experience and preparedness, combined with the possible short tenure and high mobility of political executives, may result in the lack of long term vision and understanding of the strategies of government agencies. On the positive side, political appointments without prior experience in the public sector can be an asset as such appointees may come with a better understanding of the policies and political objectives of the new government - views that the existing civil servants possibly do not understand if they have been accustomed to a different ideology held by the previous regime.

\subsubsection{Are there specific challenges to civil services in emerging democracies?}

Institutionalisation of a professional $\mathrm{CS}$ in an emerging democracy can pose a number of challenges. During the process of institutionalisation, a number of characteristics and features that are mostly though not exclusively confined to emerging democracies can also be evident, depending on the socio-political environment.

The functions of a CS are often outlined in a CS Act. As mentioned previously (section 2.3.3), the EU has advocated as a condition of accession, establishing the independence of the CS in a statute. As Ridley (1995, p. 14) points out, however, it could be argued that on the one hand new democracies should rely on such a laworiented approach to prevent abuse of power, but on the other hand if the democracy is at its infant stages, that "the rule of law approach will simply encourage elitist attitudes in the civil service". The latter argument is also supported by a number of authors. Research has found that "civil service laws have seldom been the expected catalysts for the stabilisation, depoliticisation and professionalisation of the central administration" (Verheijen, 2000, p. 29). Some have even concluded that laws are inherently incapable of producing major social change because they encourage alternative courses of action that disrupt social equilibrium (Roots, 2004). MeyerSahling $(2004$, p. 72$)$ states that in the countries of Eastern Europe which returned to 
democracy recently, "even when civil service legislation has been adopted, political interference at the top of the civil service continues to contradict attempts to establish professional civil services insulated from politics". Even when political leaders do not have the capacity to appoint their loyalists to government organisations, a variety of strategies can be employed by politicians to achieve the objectives that they desire (Peters \& Pierre, 2004). As a result, "in these nations, democratisation involves not only establishing traditional political institutions, but also improving the legitimacy of the civil service" (Andrews, 2008, p. 171).

Laws are amended according to the needs of a society and the CS Acts are no exception. However, stable and effective legislation can be important in the attempts to inculcate professional ethics amongst the civil servants. Such stability may be a rarity in nascent democracies. An evaluation undertaken by Meyer-Sahling (2009) of the CEE countries that were part of the EU enlargement in 2004 revealed that all eight countries ${ }^{24}$ scored poorly in terms of "legal predictability". Having amended their CS laws in numerous instances, such continuous changes had meant that the formal rules governing the CS had been very unstable in those countries, and the stability of the CS administration had been seriously undermined with the possibility of the development of an arbitrary management.

As mentioned previously (section 2.4.2), the thickening of government is evident even in established democracies. Such practices can have adverse effects in emerging democracies too. For example, one strategy often used in thickening is to exclude top civil servants from the scope of the CS legislation, a practice referred to by Thompson (2006) as the deinstitutionalisation ${ }^{25}$ of civil service. Thompson (2006) asserts that such practices are evident in environments overtly hostile to merit ideals. Exclusion from the parameters of the CS laws probably "weakens the accountability of the civil service and undermines the principles of professionalism

\footnotetext{
${ }^{24}$ The eight countries covered in this study were Czech Republic, Estonia, Hungary, Latvia, Lithuania, Poland, Slovakia, and Slovenia.

${ }^{25}$ According to Olsen (2009, p. 10) de-institutionalisation "implies that existing institutional borders, identities, rules, and practices; descriptions, explanations, and justifications, and resources and powers are becoming more contested and possibly discontinued. New actors are mobilized. Outcomes are more uncertain, and it is necessary to use more incentives or coercion to make people follow prescribed rules and to sanction deviance”.
} 
and political neutrality" (Meyer-Sahling, 2009, p. 21). Undoubtedly the morale of career managers is adversely affected as political executives are able to bypass them, and instead rely on lower level political appointees, thereby making career managers redundant (Ingraham, 1987). Furthermore, though such appointments are legal in many countries, political interference can result in high personnel turnover, organisational instability, and demotivation of staff at all levels, as it becomes evident that top jobs in the ministries can be obtained only by means of personal and political connections rather than on the basis of merit (Meyer-Sahling, 2009, p. 76). In this respect, Suleiman (2003) has emphasised that the ongoing practices of deprofessionalisation and politicisation of public administration in several states, and with more emphasis placed on political affiliation, loyalty, and commitment to the current government, have costs in terms of an administration's ability to serve future governments and society at large (cited in Olsen, 2005, p. 9). Regardless of the means used, the aim of political leaders is to control the powers of a bureaucracy by appointing political staff who will be used as instruments of authority over the CS.

\subsubsection{What is the role of civil service in national development?}

The classical CS model does not directly address the range of tasks that state bureaucracies are required to undertake in national development. As these tasks proliferated from the original ones of tax gathering and local magistracies, into a wide range of technical, professional, and entrepreneurial roles, the classical model focused on generalist administrators overseeing a range of these specialists, technical functions and occupations. Along with modernisation and expansion of the societies, determining the appropriate role of the government in national development became important. In other words, the extent to which the state should be involved in the societal development was questioned.

From the early twentieth century, state bureaucracy played a major developmental role, especially in the areas of social services and public utility provisions. The growth in public services came with significant rises in the cost of delivering such services and questions were once again asked regarding the role that should be

discharged by the CS. One strategy used was to fragment the single CS into a number of different modes of organisations that included semi-autonomous agencies 
and public commercial enterprises, each with their own employment rules. Thus, in some countries, the developmental role played by the central CS shifted to a more regulatory role.

Despite such changes in the role of the CS, some countries have retained its entrepreneurial role. Some argue that the CS or the bureaucracy can play a crucial role in the development of a society. In this respect, Ejifor (2003, p. 5) has argued "one of the most important catalysts of the development of nations is an efficient bureaucracy. On the other hand, one of the heaviest millstones round the neck of developing nations is an inefficient bureaucracy". Bureaucracy is ubiquitous in most developing countries and "they serve important functions in a democratic society" (Blau \& Meyer, 1971, p. 164). In addition, a bureaucracy is responsible for enforcing the law equally for all citizens and regulating the market through its institutions in order to provide a platform for anyone to acquire wealth (Blau \& Meyer, pp. 165-6).

Determining the most efficient model of public employment can be debatable. Regardless of the model adopted, the underlying assumption is that "public institutions operate on the principle that politicians, bureaucrats and trained officials are elected to act in the interests of the people as their employers" (Aadel, 2001, p. 8). For a developing country, a high degree of involvement of state bureaucracy can arguably be beneficial for state development, as evident from the experiences of the developed democracies.

\subsection{Public administration in small-island states}

Civil services of small-island states can share some common features. Before going into the details of such features, however, two cautionary notes need to be raised. Firstly, these features may also be visible in developed nations with large civil services. Second, although smallness or islandness may not have a direct correlation with public administration and institutional choices, at least an indirect linkage is evident. In this regard Baldacchino (2004, p. 278) points out, "islandness is an intervening variable that does not determine, but contours and conditions physical and social events in distinct, and distinctly relevant ways". However, in a more assertive manner, Anckar (2006, p. 43) concludes "that islandness links in many 
instances to the choice of institutional settings". These "settings" may include public administration as argued below.

The administrative features presented below can on one hand enhance the field of public administration, and on the other, be detrimental to the development of a professional CS. Identifying those features and aspects can be relevant to analysing the extent to which a professional CS institutionalises in island states. The theoretical perspective outlined below is by no means exhaustive, but is focused only on the issues that are deemed relevant to this research.

The small size of a population can at times be detrimental in establishing a politically neutral CS. Politics and public administration are closely tied to each other, which has been described as a characteristic particularly found in small societies (Murray, 1981; Randma, 2001; Sutton, 1987). As a result "there is a greater amount of mixing between politicians and civil servants and stronger personal networks beyond political ties so that it can be difficult to maintain totally separate discrete roles" (Randma, 2001, p. 48). At times, the absence of discrete roles may even lead civil servants to be politically active thereby placing the concept of neutrality in question. Pirotta (1997, p. 199) has argued that, in Malta, public service neutrality is merely a legal fiction where "large numbers of public servants openly take part in political activities." In such cases, the separation of politics from administration becomes contentious. Furthermore, anonymity of civil servants - one of the privileges enjoyed by a nation's civil servants - can also become an issue due to the small population. In this regard, according to Sutton (1987, p. 19), in small states public servants are "frequently unprepared to take risks or make decisions out of the routine without reference to superiors. Administration is therefore politicized, often centralized, and subject frequently to the narrow political vision of the small state politician".

There have been those who have opposed a politics-administration dichotomy where small states are concerned. Those who argue in favour of this separation assert that the inability of the public service or the CS to become rationally bureaucratic is the cause of limited development (Schahczenski, 1990, p. 75). On the other hand, Jones (1976, p. 94), discussing experience in the small-island states of the Caribbean, 
argues that 'the 'politicization' of the state bureaucracy and corruption and so on, need not be rejected on a priori grounds as being inconsistent with development".

Personal relationships also play a significant role in small states, much greater than in large societies. According to Baker (1992, p. 17) in small countries it is simply "impractical to separate personality from function". A small population means that even civil servants regularly interact with citizens who receive their services, either as neighbours, relatives or friends, to a greater degree when compared with larger countries. This view is supported by Misra (2004, p. 134) who states that "the prevalent interconnectedness among individual and families, society in small and micro states is far more cohesive than in their larger counterparts".

Such relations can also be a factor within organisational settings. Weber argues that the historical process of rationalisation embodies the shift from traditional authority towards legal-rational authority (Parsons, 1947). However, in some small-island states with traditional chiefly systems, there exists a mix of the two, often with tensions between them. In such countries, when personal relationships come to the fore, the concept of professionalism being maintained is questionable, because "the very fact of smallness means a tendency to greater particularism in society, because people grow up within an interdependent network and every social relationship serves many interests" (Randma, 2001, p. 48). Such relations can be considered either in a positive or a negative sense. On the positive side close personal contacts in small civil services means that relations and informal networks can enhance collaboration within the organisation and among different organisations of the CS, whereas on the negative side the objectivity of personnel decisions may be questionable (Randma, 2001).

It is also common that small states or small-island states have large civil services in comparison with their populations and a common feature of such polities is the ubiquity of government (J. Richards, 1982, p. 158). According to Feeny and Rogers (2008, p. 527), Small Island Developing States (SIDS) tend to have relatively higher ratios of government expenditure to GDP compared with other developing nations. Inability to achieve economies of scale and a lack of critical mass also tend to be common characteristics of public administration, and the resulting economic and 
social overheads lead to a high per capita cost of both public administration and economic and social infrastructure (Wettenhall, 1992). Although a number of possible reasons can be found for this phenomenon, arguably the fact that the state employs a large chunk of the working population can contribute to a relatively high wage bill of the government in relation to its total expenditure. Furthermore, it is common for governments of small states to be involved in the development of the economy to a greater extent than in larger states. Pirotta (1997, p. 202), reporting this phenomenon in the case of small but relatively developed Malta, argues that this may be the general rule in the case of micro-states.

In the past, smallness was not a requisite for being colonised. However, colonial heritage is regarded as an important linking factor between geography and politics (Anckar, 2006, p. 51; Ott, 2000, pp. 69-70; Srebrnik, 2004, pp. 333-4). Furthermore, most small-island states have had a history of colonisation. Regardless of a country's size, in most cases foreign rulers imposed their way of handling administration and, even after the colonisers left, in most cases the previously planted structure of administration remained intact. This is the case even in Caribbean nations with a long history of democratic institutions (Hope, 1983) and a professional CS (Rowat, 1996). One reason for the continuity of such institutions even after independence may be that amidst the political changes "somehow the civil service scrapes through unchanged, perhaps because the myth has really been accepted that it is neutral and objective and, therefore, "one size fits all"' (Baker, 1992, p. 14). Although this notion can be debated, the presence of such institutions in a country for an extended period of time will in most cases lead to institutionalisation of the functions that in turn strengthen the democratic state.

Small-island states also have a limited pool of qualified personnel (Jacobs, 1975, p. 136). Consequently a few individuals in such societies come into repeated contact with each other, but in a variety of roles and capacities (J. Richards, 1982, p. 157). Furthermore, due to the lack of supply of trained professionals, it may simply not be possible to locate anyone with adequate training in some technical fields, and even when such professionals are available, the government may not have the capacity to offer competitive salaries (Wettenhall, 1992). As Brown (2008, p. 11) points out, "it will never be possible for a small country of 1.5 million people or fewer to have all 
the specialists it could require in every technical or managerial area essential for its development in a modern world". This means specialists often act as generalists, and perform a broad range of functions. Even when training is provided and specialists are hired, a "brain drain" has been evident in a number of such states. As a result, the hiring of expatriate consultants is a common phenomenon. The small size of the working population combined with low pay also means that career civil servants may be forced to work in secondary employment outside the CS.

Small does not necessarily portray a negative image. Although a number of features mentioned above can potentially inhibit the development of a CS that is professional and aligned with democratic values, such attributes can be transformed to be made beneficial for the CS. As Rajbansee (1972, p. 216) has stated "one of the blessings of small size is the opportunity it gives to avoid bureaucratic rigidities."

In summary, although some of the tendencies reported here may be present in larger states as well, in small societies, it is arguable that civil servants may find it harder to separate their official duties from their private lives and personal responsibilities; may be subject to greater personal exposure or the decisions they take on delegated authority; and may find that they are more subject to micro-management by politicians than in larger governments and organisations.

\subsection{Policy formulation, decision-making, and political interactions}

The decision on the form of a CS legislation in the Maldives was one of public policy being "whatever governments choose to do or not to do" (Dye, 1975, p. 1). Key to the definition of public policy is the idea of a process to reach a decision (Birkland, 2005, p. 213). Policy formulation and decision-making are integral parts of the policy process. Policy formulation involves "exploring the various options or alternative courses of action available for addressing a problem" (Howlett, Ramesh, \& Perl, 2009, p. 110). Such options are identified after the actors begin to tackle a policy problem. During the decision-making process, an option is chosen as the course of action. Actors or organisations involved in the policy process debate options presented to them before arriving at a decision. The decisions on which 
public policies are based can come in different forms, such as legislation, executive orders, or other official acts (May, 2003, p. 223).

Review of these stages of the policy process is the focus of this thesis because of the analysis of the CS Act that emerged during the democratisation process. This segment of the chapter focuses on the interaction of actors in the policy formulation and decision-making stages during the enactment of the relevant legislation. Though the primary focus is on how the legislative process shaped the CS Act in the Maldives, a broader perspective is required on the wider policy process and the interaction of the main actors in the process.

Governments normally initiate policy formulation. However, it is also possible in the case of a government's inability or reluctance, that the legislature takes the initiative to push through certain reforms. In this regard, Carey $(2009$, p. 1) states that apart from making laws, legislatures can be an important policy-making institution as they approve budgets and make other fundamental policy decisions. However, exactly what role a legislature and its members will have in policy-making is subject to a great deal of variation in different nations.

Olson and Mezey (1991, p. 6) suggest two paths for policy-making by the legislature. The first depends on the relationship of the legislature to other political institutions and actors, such as executive elites, political parties, constituencies, and interest groups. The second is concerned with the internal structure of the legislature, such as the strength of committee systems, access to professional staff and the degree of control exercised by the political party machinery. However, the focus of this research is on the first category and on how these actors influence and contribute to policy formulation. The reason for choosing this category is the availability and accessibility of relevant information. On the other hand the reason for excluding the second category is simply because it involves the study of parliament and its internal structures, including mechanisms such as access to professional staff, development of an established committee system, and direct control by the political parties. These latter aspects are still in their infant stages in the Maldivian case study examined in this thesis, thereby making it difficult to collect comprehensive data. 
The legislature can play a significant role regardless of whether the form of government is presidential or parliamentary. As Howlett et al., (2009, p. 60) note, even in a nation with a presidential form of government, its members of parliament and its committees play an active role in designing policies. Irrespective of the form of government, how such actors interact in decision-making determines the outcome of the legislative process.

Why does administrative reform come onto the legislative agenda? Geddes (1994, pp. 83-99) argues that when political parties have relatively equal strength in the legislature, politicians will be more likely to adopt bureaucratic reform. This may be because if one party dominates the legislature it will probably have little political incentive to push for such reforms as the dominant party can use the CS for political gains. On the other hand, if two dominant groups have equal strength in the legislature, one or the other has little to lose but possible electoral gains on offer if they are seen advocating for administrative reform. Nonetheless, even in the case of a single party domination, they may opt for reform in cases where "public outrage over bureaucratic incompetence and graft had become so vehement that politicians might fear that they would lose more votes by opposing reform than by reducing their ability to distribute patronage" (Geddes, 1994, p. 95). Furthermore, legislators who do not necessarily have strong convictions about a specific policy might be among the most fervent advocates of that policy simply because they believe it will appeal to their constituents (Shils, 1959, p. 348).

Decisions are made through voting in the legislature, and, prior to casting of the votes, any bill is bound to have to navigate its way through a number of channels. Most of the policymaking and bargaining among legislators takes place before it reaches the voting stage, possibly at the committee stage, or even before the bill is submitted to the legislature. As mentioned above, the propensity for legislators to bargain can result from the strength of parties in the parliament as well as the possible gains and losses on offer by choosing or rejecting a specific policy. Such discussions can be held "in public pronouncements and debate, in legislative committees and party caucuses, or during negotiations between executive and legislative actors or between party leaders and rank-and-file legislators" (Carey, 2009, p. 46). However, eventually the decisions made by law-makers will be 
dependent on both instrumental and non-instrumental motives for being involved in the interests of the constituencies (Esaiasson \& Holmberg, 1996, p. 279). On a personal level, the law-makers will assess their probability of re-election. Furthermore, they will assess the prevailing norms thereby attempting to pursue “normatively appropriate behaviour" (March \& Olsen, 1984, p. 744). Although analysing motives is a daunting task, discussions in parliament and the symbols ${ }^{26}$ evident during the process provide clues about assumptions underlying decisions made by political actors.

Upon the initiation of a public policy by the legislature, why does a government choose to back such reform alternatives? According to Sahlin-Andersson (2002, p. 47), the motives for a government to launch reform, the opportunities available to a government, and the changes such reforms lead to, depends on the constitutional arrangements (Olsen \& Peters, 1996), administrative systems (Christensen \& Lægreid, 1999; Hood, 1995), reform traditions (Pallot, 1998) and the cultures (Christensen \& Lægreid, 1999) of that particular nation. For instance, past practices revealing how an administration operated, especially where there have been cases of mismanagement and unethical acts, can determine the need to push for such reforms. Perception of dissatisfaction regarding past policies within segments of a government can also provide reasons for pushing through reforms.

As indicated above, not all policies originate from parliament. So where do policy options originate from during the formulation stage? In most cases they are borrowed from the practices of other countries. This is referred to in the contemporary literature as policy transfer. According to Dolowitz and Marsh (1998, p. 56) policy transfer "refers to the process by which actors borrow programmes and policies from one setting to develop programmes and policies within another". Though related notions such as policy convergence, policy diffusion, emulation and lesson-drawing are used, they are all partially overlapping concepts. As this research examines the processes of formulation of the CS, the term policy transfer is suitable as it is concerned more with processes rather than with results.

\footnotetext{
${ }^{26}$ The term "symbol" is used here to denote the actions and reactions of the MPs through different means such as delaying tactics, nature of their speech, verbal gestures, and so forth.
} 
Dolowitz and Marsh have developed a framework for analysis of policy transfer which asks questions as: Why do actors engage in policy transfer? Who are the key actors involved in the policy transfer process? What is transferred? From where are lessons drawn? What are the different degrees of transfer? What restricts or facilitates the policy transfer process? How is the process of policy transfer related to policy "success" or policy "failure"? (Dolowitz \& Marsh, 2000). Answers to these questions help explain the processes involved. This thesis attempts to identify the origins of the policy formulation of the CS Act, and some aspects of this process seem to be explained by a process of policy transfer.

The above questions also include further examination of the role of the political actors which is an important aspect of this thesis. Dolowitz and Marsh (2000, p. 10) identify nine main categories of political actors involved in the policy transfer: elected officials, political parties, bureaucrats/civil servants, pressure groups, policy entrepreneurs and experts, transnational corporations, think tanks, supra-national governmental and nongovernmental institutions, and consultants. Depending on the type of policy transfer, the degree of involvement of such actors will vary. Which of these actors influenced the policy transfer process, and the extent to which those actors influenced the process in the Maldives, is examined later (see sections 6.2 to $6.7)$.

The size of a country can also affect the nature of decision-making by political actors. In the case of small-island states, members of the political inner circle will know each other quite well. In such countries the effects of decisions are pervasive due to the interlocking of role relationships among the political actors and the availability of monitoring mechanisms to oversee the implementation of such decisions through economic, legal, political, and social pressures (J. Richards, 1982). As a result it is more likely that they will cooperate with each other and it is more likely that they will choose compromise over confrontation (Ott, 2000, p. 195). Research also often suggests that in some countries, despite apparent divisions, the political actors are socially and ideologically united (Blondel \& Müller-Rommel, 2007, p. 820). However, where disagreement exists, differences of opinion will be taken on a more personal level (J. Richards, 1982). In either case, the timing of any policy transfer is crucial, as decisions taken by political actors will encompass either 
voluntary or coercive elements depending on the periods of social, political, and economic stability, or on some form of political crisis (Dolowitz \& Marsh, 2000, p. 17). In other words, during times of political instability political actors might have to approve certain reforms due to environmental pressures, reforms that might be not pursued in times of harmony.

\subsection{Conclusion: Implications for the case of the Maldives}

The aim of this chapter was to develop the basic propositions of the two research questions that will be the basis of the analysis of the Maldives case. The propositions developed in this chapter on democratisation and CS, taking into account the specific context of a small-island state, will form the basis for analysis of the evidence from the Maldives case. The literature reviewed in this chapter suggests that the democratisation process results from a combination of factors with a number of outcomes possible. It also suggests that particular characteristics of small-island states can also be a factor in democratisation and institution building. Redefining the boundaries between the political and administrative arm of the executive in such a setting has numerous challenges, which current studies do not adequately explain. However, application of the theories and processes reviewed in the chapter to the Maldivian case can make an important contribution to understanding the processes of democratisation and the CS development in the context of small-island states.

Democratisation can follow different paths and at times steady economic and social progress can contribute to democratic reform. In the event of long history of authoritarian rule, politically significant triggering events leading to mass uprisings can also be pivotal in accelerating the reform process. At some stage this process will include negotiation of the institutional settings.

Reform of the CS can be one component of this negotiation. The shape of the future statutory CS is determined normally by the political strength of actors and their commitment to the CS reform. However, when democratic reform and CS reform are pursued in a nation where the CS has historically been controlled by an autocratic political executive, there may be a move to entrench a statutory CS relatively independent of the political powers and intended to be distanced from future political 
control. The possible effects of such a policy can be the creation of a CS that may not be completely responsive to the elected government.

Often the CS reform is one component of the political and governance reform agenda. Reform of the CS may thus not be at the top of the agenda: especially when democratic reforms proceed in an accelerated pace, the CS reform may not get the full attention it requires. Thus policy makers may adopt the previously maintained centralised model of administration, simply transferring the powers from the political executive to a statutory body.

There are common features of political and public administration among small-island states, which may play a part in reform policies and processes. The geographical dispersion of islands in most small-island states often leads to the adoption of a decentralised system of government, while the CS reform remains under central control. When the CS reform and political governance reform diverge in such a manner, compatibility issues tend to appear.

Implementation of democratic reforms does not necessarily eliminate or reduce politicisation of the CS. Although a statutory CS may be designed to draw a stronger line between policy and administration, there will still be a tension between political priorities and CS autonomy. As politicisation is evident in large and small countries, it may have a particularly strong effect in small-island states. The interlocking relationships observed in small-island states means that when politicisation takes place in the public domain, questions may arise regarding the integrity of the state institutions and their constitutional powers. Questions on the chosen model of the CS as well as the legality of the challenges that are faced during the consolidation of the reform may surface.

Emerging democracy implies consolidation is yet to be reached. When fierce political differences remain among the political actors of small-island states, using the CS to forward one's own political agenda has a higher probability. This is especially relevant when, following a long history of authoritarian rule, a newly elected government goes on a crusade to remedy what it considers failed past practices. Along with the volatility of such an environment and the administrative 
history of the nation, the statutory CS may be inclined to defend itself by adopting a law-oriented approach in the management of the CS. Additionally, institutionalisation of a professional CS is hindered when politicians use a number of mechanisms to de-institutionalise the CS along with attempts to reshape the scope of the CS.

To date, the topics reviewed in this chapter have only been addressed separately in contemporary academic literature. The intricacies of the dynamics between these processes are expected to become clearer, at least in the case of the Maldives, when the democratisation process, the formulation of the CS, and the interplay between the two processes are examined from Chapters Four to Seven. Those chapters use germane documents, statistics, and data along with observations on ideas of interviewees to draw conclusions from the scholarship presented in this chapter. The next chapter discusses the research design and methodology used to gather and analyse the empirical data. 


\section{CHAPTER 3: RESEARCH DESIGN AND METHODOLOGY}

This chapter discuss the research design and methodology adopted for this research. The chapter begins with an overview of the epistemological and ontological stance taken. Next section examines the research design, followed by a discussion of the case study strategy of inquiry, and why it was preferred in undertaking this research. The next two sections discuss issues surrounding generalisation and possible limitations of the thesis. The last three sections present the data sources used for the study, methods of data collection, and data analysis process.

\subsection{Epistemology and ontology}

Epistemology is the theory of knowledge and ontology is concerned with the nature of reality. In other words, "epistemology deals with problems of knowing" while ontology gives "referents of knowledge, if indeed there are any" (D. T. Campbell, 1988, p. 440). Crotty (1998, p. 10) clarifies that ontology relates to understanding what is, while epistemology relates to understanding what it means to know. It is common that such philosophical ideas remain mostly hidden in research (Slife \& Williams, 1995). Nonetheless, as Creswell (2009, p. 5) states "they still influence the practice of research and need to be identified".

This thesis is based on a mild form of social constructivism. Crotty (1998, p. 42) defines constructivism as a view in which "all knowledge, and therefore all meaningful reality as such, is contingent upon human practices, being constructed in and out of interaction between human beings and their world, and developed and transmitted within an essentially social context". I am not denying that there is a reality of events that exists separately from the way we perceive them but I am arguing that there is a "social reality" which is made up of commonly held beliefs and understandings about these events.

Institutionalism can be understood as a way of understanding the persistence of forms of social organisation. Hall and Taylor (1996, p. 936), distinguish three schools of institutionalism: historical institutionalism; rational choice institutionalism; and sociological institutionalism. According to Hall and Taylor 
(1996, p. 938), historical institutionalists define institutions as "formal or informal procedures, routines, norms and conventions embedded in the organizational structure of the polity or political economy". Rational choice institutionalists use “"new economics of organization' which emphasizes the importance of property rights, rent-seeking, and transactions costs to the operation and development of institutions" (Hall \& Taylor, 1996, p. 943). Sociological institutionalists argue that institutional forms and procedures used in modern organisations should be seen as culturally-specific practices (Hall \& Taylor, 1996, p. 946).

Premfors (1998) discusses the differences on issues of ontology and rationality among these types of institutionalism. He argues that historical institutionalism relates to: formal and informal structures (institutions), not classes or norms; weak constructivism (ontology); appropriateness (rationality); public policies and power constellations (key study objects) (Premfors, 1998, 147).

This thesis is a study of institutional change that occurred over a relatively short period of time but emerged from the existing institutions of public life in the Maldives. Therefore, the appropriate approach for this thesis is historical institutionalism. Institutional change can be deliberately negotiated, but it is always subject to the particular institutions and history of the country, so that it never starts with a "blank canvas". Adopting others' words, it is therefore "closer to a mildly constructivist historical institutionalism [rather] than to either rational choice or the more strongly constructivist sociological institutionalism" (Pollitt \& Bouckaert, 2004, p. 23). I am interested in people's ideas about the CS and democracy and how they influenced the development and implementation of the CS Act. Rather than observing what people did or asking them what they did, this study quite often asked them for their observations on ideas which are not their own and events in which they may not have directly taken part. The responses are historical in the sense that I am constructing a narrative after the event. The influences on the people are the ideas of others but also "the rules of the game" that are inherited from the preexisting institutions of the Maldivian society. As the study brings economics and political power into the discussions, it is not just about exchange of ideas but also about some underlying historical forces. 


\subsection{Research design}

According to Saunders, Lewis and Thornhill (2007, p. 5), research involves a multistage process which one follows systematically in order to undertake and complete a study. Consequently, every study should have a specified research design. Creswell (2009, p. 5) refers to research design as the "plan or proposal to conduct research, [which] involves the intersection of philosophy, strategies of inquiry, and specific methods". This research uses a qualitative research design in operationalising the research questions and the theoretical framework presented in the previous two chapters.

The study examines the processes and the interactions between different actors and institutions in the establishment of a statutory CS. An in-depth analysis of these aspects is examined by choosing a qualitative design and using the meanings people attach to such involvements. That is because "qualitative researchers are interested in understanding how people interpret their experiences, how they construct their worlds, and what meaning they attribute to their experiences" (Merriam, 2009, p. 5). Taylor and Bogdan (1998, pp. 7-8) assert that qualitative approaches allow the researcher to understand the meanings people attach to things in their lives and adopt strategies to examine the way people act in the course of daily life. Therefore, by choosing a qualitative approach, a "deeper" understanding of such social phenomena can be studied (Silverman, 2005, p. 10). The approach paves the way to identifying possible implications for the establishment and institutionalisation of a statutory CS by identifying the patterns involved as derived from the rich information gathered.

In collecting data for this study, I had some ideas about which documents might be relevant and who to approach for interviews, but I was open to interpretations that arose from the evidence itself, rather than my preconceived ideas and potential biases (refer to sections 1.4 and 3.5).

\subsection{Case study research strategy}

Eisenhardt (1989, p. 534) explains, "case study is a research strategy which focuses on understanding the dynamics present within single settings". Firstly though, what 
is a case study? Thomas (2011a, p. 513) defines case study as "analyses of persons, events, decisions, periods, projects, policies, institutions, or other systems that are studied holistically by one or more methods". There are numerous other definitions of "case studies" (see Bennett, 2004, p. 21; Creswell, 1998, p. 61; George \& Bennett, 2004, pp. 17-18; Gerring, 2004, p. 342; Seawright \& Collier, 2010, p. 315-6; Simons, 2009, p. 21). According to Morris and Wood (1991, cited in Saunders et al., 2007, p. 139), case study strategy is the preferred option when the researcher seeks to obtain a rich understanding of a particular context and process.

In a case study, it is important to distinguish what it is a case study of, and what it is a case study about. In other words, what is the subject of the case and what is the object of the case. Thomas (2011a, p. 511) argues that: "(1) the subject of the study, which is the case itself, and (2) the object, which is the analytical frame or theory through which the subject is viewed and which the subject explicates". The Korean War, for example, can be considered the subject of a case, while U.S. resistance to putative communist expansion can be considered the object of that case (Thomas, 2011a). In line with such a distinction, the subject of this thesis is the development of the current CS model of the Maldives during the reforms that followed mainly after 2003. The object is the interaction between the process of democratisation and the institutional development of the CS.

\subsection{Generalisation}

In case studies, "generalizability refers to the capacity of the case to be informative about a general phenomenon, to be broadly applicable beyond the specific site, population, time, and circumstances studied" (Mabry, 2008, p. 222). Thomas (2011b) states that it can be difficult to use generalisation criteria in case studies, while Stake (2000, p. 19) notes that case studies are widely seen as non-useful because "they are not a suitable basis for generalization". Such views do not necessarily diminish the importance of case studies.

Ruddin (2006) argues that: 1) generalisation is essential to understanding the world; 2) there is no point doing a case study unless you expect to generalise from it; and 3) publishing a case study is a statement of generalisability in its own sense. Ruddin 
(2006, p. 800) further states that generalisation in the single case study is not a matter of statistical inference, but of "imposing meaning" on the subject of the case study - the meaning being the statement of the object of the study. In this thesis, that will be the development of the current CS model in the Maldives through the mutual determination of a process of democratisation and the formation of a statutory CS.

Flyvbjerg (2011, p. 302) observes, "case study as a methodology is generally held in low regard, or is simply ignored, within the academy". According to him, this is a result of a misunderstanding that one cannot generalise on the basis of a single case study (Flyvbjerg, 2011). The scope of this study has been limited to the Maldives by the limited resources and time constraints available to undertake the research. A comparative case study or a multiple case study approach would probably lead to better generalisations and applications to other small-island states. Then again, comparative cases will also differ in important matters; for example no other smallisland state has gone through similar changes in such a relatively short period in the recent past, where a statutory CS was established along with a transformation to a multi-party democratic system simultaneously.

According to Stake (1995, p. xi), "case study is the study of particularity and complexity of a single case, coming to understand its activity within important circumstances". Thus, this study aims only to discuss the role of a CS in a smallisland state through the Maldivian experience and to add to a body of knowledge on the objects of the case study. It is possible that other countries share characteristics with the Maldives in relation to political processes and institution building and, therefore, the Maldivian experience may be beneficial to such countries on the path towards democratic consolidation and strengthening of state administration. Additionally, for the Maldivians to make sense of their own experience, possible lessons for the Maldivian CS are also outlined in the conclusion chapter (see section 8.4).

\subsection{Limitations}

Limitations of this study regarding generalisation based on a single case study are presented above. This section presents other possible limitations of this thesis. 
1. As mentioned in Chapter One (section 1.4), I was a participant in some of the events described in this thesis. In addition to semi-structured interviews and secondary documents, I also used my previous work knowledge to a lesser extent to complement and increase the validity of the research. On the one hand, such past involvement provides an opportunity to investigate beyond the interviews and documents. In other words, it opens up "an opportunity to get beyond people's opinions and self-interpretations of their attitudes and behaviours, towards an evaluation of their actions in practice" (D. E. Gray, 2009, p. 397). However, on the other hand, such close involvement can be perceived to facilitate personal biases towards the case. I acknowledge that I have my own standpoints and perceptions on social, cultural and political issues of the Maldives. To conduct the research in a professional manner and to maintain a "value-neutral position" (Berg, 2009, p. 200), such potential biases are counteracted by not using my own experience as "data" in this research, but only to verify the data collected through interviews and documents. I have intentionally provided a personal observation in this thesis in only one instance (see section 4.4.2).

2. Bias on the part of the interviewees is also a possibility. The majority of the interviewees for this research are public figures who are politically aligned to one side or another. At the time of the interviews, there were major political tensions in the Maldives: concern for maintaining reputations and consideration of the future may have influenced their responses to my questions. Certainly, the political views of some interviewees were very visible during the interviews. To counter this, political statements have not been used in the thesis. Furthermore, as mentioned later (see section 3.8), wherever possible, documents were used to substantiate some of the statements made by the interviewees.

3. Another potential issue could be the problem of "shared meaning" in critical terms such as "democracy" and "civil service" used in the interview questions. As stated (see section 3.8), the majority of the interviews were conducted in English. Interviewees who preferred to conduct the interview in the local language were not necessarily unfamiliar with English; they simply were more comfortable expressing themselves in the local language. Additionally, the crucial terminologies of the interviews were presented in English, even in the interviews conducted in the local language, as such words were well-known in 
daily vocabulary. However, there is a possibility that when translating from the local language to English, some concepts and terms might not mean exactly the same in the English translation. This is the case for both interviews and secondary documents that were translated. Furthermore, even when the interviews were in English and the critical terminologies well-known, some interviewees may have attached varying meanings to terms such as "democracy" which do not have a universal definition (see section 1.5.3).

4. May 2008 marked the birth of the statutory CS in the Maldives. The first multiparty election in the country was held in October 2008. The democratisation process is still unfolding and the consolidation of democracy will require several more years. In other words, the story "isn't over". Consequently, references to the events and processes until March 2012 are mentioned in this thesis. A reminder about the unfolding political changes was evident in February 2012. Recurring political turmoil led to a police-initiated mutiny that resulted in the highly disputed resignation of the first democratically elected president (see section 4.5.1). Therefore, analysing a process that is unfolding in an emerging democracy might be considered premature, considering the short span of time that has elapsed. On the other hand, conducting a study at such early stages while witnessing the process unfolding could provide valuable lessons for the future which may help to strengthen the Maldivian CS as well as assist in the consolidation of democracy. In other words, what is being witnessed presently is what Lægreid (2002, p. 163) called the "adjustment effects of the reform", and analysing the reforms at this early stage can make it possible to isolate the impact of democratisation from other possible factors such as socio-economic changes that may affect the polity.

5. Questions can still arise regarding the impact of President Nasheed's resignation on this thesis. The main response to such concerns is that this thesis is not about predicting the sustainability of democracy in the Maldives - a fact evident by the use of the word "emerging" in the title of the thesis. Rather, it examines the formulation of the current CS model and how it interacts with the democratic changes. In other words, his resignation does not have a significant impact on the presentation of this case study. 


\subsection{Data sources}

A case study is often conducted in great detail and thereby mostly depends on the use of several data sources (Orum, Feagin, \& Sjoberg, 1991, p. 2). By using multiple sources, researchers "strive to thoroughly explore day-to-day interactions, how things transpire, and the individual meanings of these events for the people involved" (Lapan, Quartaroli, \& Riemer, 2012, p. 8). While use of multiple data sources paves the way for triangulation (refer to section 3.8), multiple sources provide a richer picture of the phenomenon under study by viewing the same attributes of the subject of the case from different perspectives.

Two main data sources were used for this research; semi-structured interviews and secondary documents. As L. Richards and Morse (2007, p. 114) indicate, semistructured questions are used when the researcher is to some extent familiar with the concepts that are being studied but does not know enough to be able to anticipate the answers from the interviewees. Furthermore, the authors have argued that in such cases open-ended questions are arranged logically and the same questions are asked of all participants, although not necessarily in the same order, and supplementary questions are asked as the interview progresses.

The sampling used to determine the interviewees was not probability sampling or convenience sampling, but what Patton (1990) refers to as purposeful sampling. According to Maxwell (2009, p. 235), "this is a strategy in which particular settings, persons, or events are deliberately selected for the important information they can provide that cannot be gotten as well from other choices". As the establishment of a CS was not a decision made by the general public but by selected political actors, using a purposeful sampling strategy allowed me to delve into the reasoning and the thoughts of individuals who were important to the processes that were being researched.

Secondary documents collected for the research were from government organisations and multinational bodies. Newspaper articles were also used as a guide in determining the chronology of events during the democratisation process and the formulation of the CS. 


\subsection{Methods of data collection}

The field research for this project was carried out from May 8, 2010 to October 11, 2010 in Male', the capital of the Maldives. This section describes the methods used for the two main data collection activities of interviewing and secondary documents.

Three main groups were targeted for interviewing: (1) senior politicians; (2) senior government officials; and (3) senior officials of the former government involved during the establishment of the CS. For the purpose of obtaining an outside perspective, a civil society and a media organisation were also approached. The social contacts that I had developed over the years were used to contact potential interviewees. To some extent, some of my former colleagues and friends assisted in approaching potential interviewees.

For most potential interviewees three documents were sent prior to the interview (although some requested that I bring the documents to the interview):

a) A letter requesting an interview.

b) A letter explaining the nature of the research, how interviews would be conducted, how the information gathered would be handled and stored, and how confidentiality aspects of the research would be managed. (Annex 1)

c) A consent form to be filled by the interviewee (Annex 2).

Prior to each interview, respondents were given an overview of the research, and thus they were well informed about their participation. Subsequently, all respondents signed the consent form.

The majority of the interviewees were senior officials who were in the public sector when the CS was being established, but who no longer work in the government (because of the change of government) although some of them are politically active in different capacities. Interviewing such prominent figures meant that I was able to "learn more about the inner workings of the political process, the machinations between influential actors and how a sequence of events was viewed and responded to within the political machine" (Lilleker, 2003, p. 208). 
It was a challenge to obtain interviews from some of the officials. Although most of those approached for interviews responded positively, there were some who were reluctant to be interviewed. Despite numerous reminders throughout my stay in Male', they did not respond to my requests. One potential interviewee also postponed the interview several times, and it ultimately did not materialise. The elusiveness of some of the potential interviewees suggests that they did not want to participate in research of such high political salience. From about 30 individuals approached, a total of 22 interviews were obtained (The list of the general groups to which interviewees belong is given in Annex 3).

Secondary documents were also a vital source of information for this project. As a result, a number of government organisations were approached under the "Right to Information Regulation" of the Maldives. A government form was filled and sent to each organisation along with a letter outlining the objective of the research. The majority of the documents were obtained from the parliament and the CSC. Parliamentary documents include Acts, bills, minutes, and reports. The CSC documents include annual reports, official statistics, and a number of other published documents relevant to this research. Reports and documents from a number of other government organisations were also obtained. Documents were also obtained from a number of international organisations' websites. Local newspaper websites were continually monitored for any relevant information for the research. Throughout the field research, I maintained a diary that recorded my daily work, to ensure consistency and justification for the whole process.

Most of the information that was requested from government organisations was provided in due time. However, several documents were unobtainable for a number of reasons. One organisation said that some of the information requested was historical which meant that they needed to access their archive. Interestingly those documents belong to the period of 2005 to 2007 . Unfortunately those documents were never received. In another instance, a piece of information was requested from two different government ministries, neither of which could locate it. After I sent an additional letter to one of those ministries regarding the matter, I received a phone call from the permanent secretary of the ministry - which also did not result in a positive outcome. More importantly another government organisation refused to 
provide some of the information requested, claiming that it was classified as internal documents that were not for public viewing. Such a response could have been legally challenged under the "Right to Information Regulation" of the Maldives. It is worthwhile to mention here that such discretion and secrecy resembles the pre-1960s European democracies (OECD, 1999). During that period:

the only application of the principle of openness in the majority of Western democracies was, on the one hand, the principle that legal regulations could only enter into force once published in an official bulletin or journal, and on the other, that administrative decisions could only be applicable once they had been officially and duly forwarded to and received by those concerned. (OECD, 1999, p. 12)

The Maldives as an emerging democracy has a long way to go to match the same standards of access to official information as those found in mature democracies today.

\subsection{Data analysis process}

Data analysis entails reflecting on the collected data and taking steps to understand what the data represents and interpreting the larger meaning of the data (Creswell, 2009, p. 183). Firstly, I transcribed all the interviews. Of the 22 interviews, six were conducted in the local language, the rest in English. An external translator was hired to translate the interviews conducted in the local language. Secondly, all the interviews were coded using NVivo. Themes were developed through coding.

I also read all the secondary documents collected. Notes were made on the documents about how they related to the themes developed through the coding of interviews. Analysing documents such as parliamentary minutes was undertaken with caution. Given that there was a political debate going on regarding the CS reform, it made particular sense to ensure that any statement of "fact" by parliamentarians could be cross checked against other sources. Whenever possible, documents were also used to substantiate some of the statements made by the interviewees. 
By using both interview data and secondary documents, common patterns and themes were identified. Through triangulation and explanation, connections were established in relation to the research questions of the thesis. As this research involves the interviewing of some of the most prominent political leaders as well as senior officials from government organisations, it was of prime importance that it be carried out with extra diligence in order to protect the confidentiality of those involved. In instances where direct or indirect quotes are used in the study, the identity of the person is not revealed. Instead, I used a general reference to an individual based on their political, institutional, or group affiliation (see Annex 3).

The next chapter examines the democratisation process in the Maldives. 


\section{CHAPTER 4: A NEW DAWN - DEMOCRATISATION IN THE MALDIVES}

\subsection{Introduction}

This chapter analyses the democratic transition in the Maldives. As formulation of a statutory CS was one component of the democratisation process, this chapter sets the scene for analysing the interaction between the CS model and the democratisation process, a discussion presented in Chapter Seven. This chapter argues that, for all the recorded history of the Maldives, a strong centralised and autocratic system of government has been in place, though with some qualifications. It also argues that the effects of modernisation, most particularly the emergence of an educated population, have contributed to the rise of self-expression values that contributed to the rise of new elites as well as demand for greater political participation.

The chapter begins with a brief profile of the Maldives. The rest of the chapter is divided into three main parts that follow the general outline presented in section 2.2 of Chapter Two, which focuses on democratisation. Those three parts are: democratisation process; causes of democratisation; and results of democratisation in which this thesis argues the Maldives is an emerging democracy that is presently frail and unconsolidated. Each of these parts is further subdivided into a number of sections, the detail of which is presented at the beginning of each part.

A cut-off point of March 2012 is used in presenting the events in this chapter, at which point the democratic reforms were still at an early stage. Categorising the Maldives as a frail and unconsolidated emerging democracy does not imply that democratic transition has failed in the Maldives; rather it shows the challenges that are being faced at this early stage of the process and the considerable work ahead to move into democratic consolidation (refer to Annex 4 for a timeline of important events mentioned in this thesis).

\subsection{Country profile}

The Republic of Maldives is located in the Indian Ocean, with Sri Lanka and India being the closest neighbours (see figure 4.1, p. 94). It is an archipelago of 1190 
islands grouped into 26 atolls, ${ }^{27}$ in which the highest islands are barely three metres above sea level. The island nation spans $822 \mathrm{kms}$ from north to south and $130 \mathrm{kms}$ from east to west. The Maldives is $100 \%$ Sunni Muslim. The population is approximately $330,000^{28}$ (Department of National Planning [DNP], 2011), all of whom speak the same language, Dhivehi. The capital island, Male', is the hub of all government and economic activities that sustain approximately a third of the entire population.

Of the country's 191 inhabited island communities (DNP, 2010), with the exception of the national capital, only four have a population of more than 5000. There are 95 inhabited islands with less than 1000 people and 28 islands have a population of less than 500 (DNP, 2010) (see table 4.1). The dispersion of the population to such small communities poses complex challenges for the governance, public administration, and delivery of state services that are further explained in this and the following chapters.

Table 4.1: Registered population in inhabited islands as of December 2009

\begin{tabular}{|c|c|}
\hline Population & $\begin{array}{c}\text { Number of } \\
\text { Islands }\end{array}$ \\
\hline Less than 199 & 1 \\
\hline $200-299$ & 7 \\
\hline $300-399$ & 8 \\
\hline $400-499$ & 12 \\
\hline $500-599$ & 14 \\
\hline $600-699$ & 14 \\
\hline $700-799$ & 14 \\
\hline $800-899$ & 13 \\
\hline $900-999$ & 12 \\
\hline $1000-1999$ & 62 \\
\hline $2000-4999$ & 29 \\
\hline $5000-9999$ & 2 \\
\hline $10,000+$ & 3 \\
\hline
\end{tabular}

Source: DNP (2010)

${ }^{27}$ An atoll is defined by Webster's Dictionary as a ring-shaped coral island and its associated reef, nearly or quite enclosing a lagoon.

${ }^{28}$ Projected mid-year population for 2012. 
Figure 4.1: Map of the Maldives

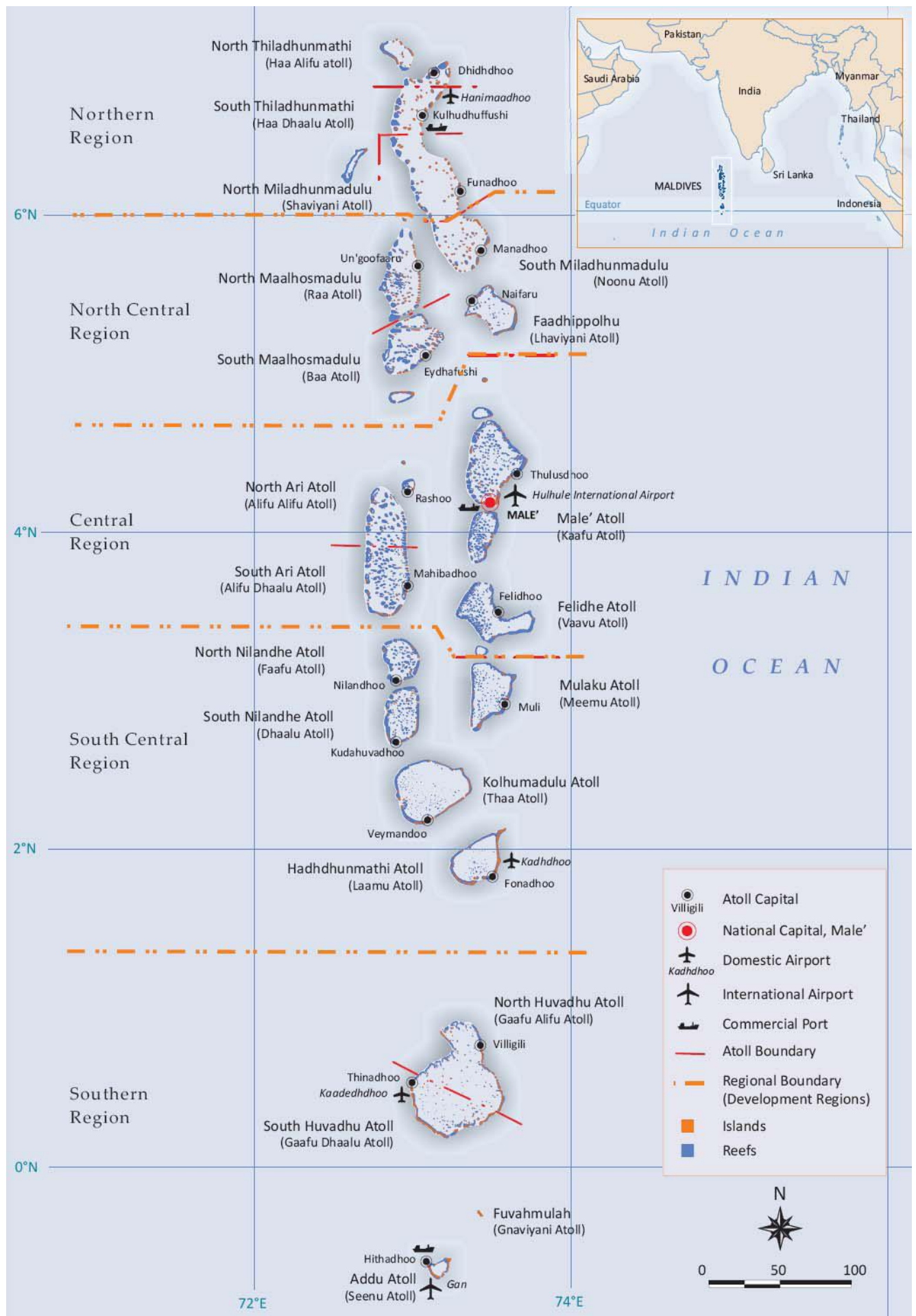

Source: Ministry of Planning and National Development [MPND] (2007a, p. vii)

\subsection{Democratisation process in the Maldives}

As defined earlier (sections 1.5.3 and 2.2.1), democratisation is a process whereby a nation moves from a less democratic and usually more autocratic form of rule 
towards one that incorporates basic democratic principles of open political competition, political participation, and civil and political liberties. The change process in the Maldives reveals what Huntington (1991-2) refers to as transplacement, which occurs when transition is the result of joint action of government and opposition groups. The Maldivian transition can also be categorised as what Welzel $(2009$, p. 87) refers to as responsive democratisation, which is a transition driven by the general public. Why the Maldives democratic transition process can be categorised this way is discussed below.

In order to analyse the democratisation process in the Maldives, this part of the chapter is divided into three main sections. The first section presents an overview of the political history of the nation to show the context in which democratic transition unfolded. The second section presents the political system from 1978 to 2003. This time frame is chosen because 1978 is considered as the beginning of a new chapter in the Maldives, and 2003 marks the beginning of the transition towards a multiparty democracy. The final section shows the democratic process from 2003 until the end of 2008 when the first multi-party election was held.

\subsubsection{Political history.}

The early history of the Maldives is shrouded "in obscurity - the natural result of their complete isolation and comparative insignificance" (Bell, 1883/2004, p. 21). The written history of the island nation began in 1153 A.D. when it converted to Islam (Reynolds, 1975), although ruins of Buddhist temples bear testimony to an even longer history (Maumoon, 2002). In this regard, while some believe that the Maldives have been inhabited for over two thousand years (N. Mohamed, 2002), others date it even earlier (Heyerdahl, 1986).

Traditionally the Maldives has been a "monarchy ruled by dynasties of kings and queens over a long unbroken period of time" (N. Mohamed, 2005, p. 4). Kings and queens were referred to as sultans and sultanas respectively after the nation converted to Islam. A sultan is the ruler of a Muslim country. The first sultan of the Maldives, Sultan Mohammed Ibn Abdulla, converted from Buddhism in 1153 A.D (Department of Information and Broadcasting [DIB], 1985, pp. 7-8). A total of 89 
sultans and three sultanas (Phadnis \& Luithui, 1985, p. 10) spanning over six dynasties ruled Maldives until the country became a Republic in 1968.

Interestingly, the post of sultan was not hereditary with the son succeeding the father, and it was quite rare for such a succession to take place. Determining the succession to the throne was often marked by coups and squabbles which are common in many monarchical systems (Phadnis \& Luithui, 1985). Even from the early years, although the sultan had absolute powers, his actions were checked by councils of advisers and chiefs that even used their powers to depose the sultan on several occasions (DIB, 1990). Furthermore, the sultan was not considered "above the laws [sic]" (Bell, 1883/2004, p. 64). Such practices show that the Maldives had hints of democratic principles in its polity even during earlier times.

Although the Maldives remained an independent country throughout most of its history, there were two brief periods of foreign domination, firstly by the Portuguese $(1558-1573)^{29}$, a period of terror and violence during which the occupiers forcefully tried to convert the locals to Christianity (Maumoon, 2002). Portuguese rule was brought to an end ${ }^{30}$ by the revered national hero Mohammad Thakurufaanu and his two brothers who prevailed after eight years of guerrilla warfare (Maumoon, 2002). Mohammad Thakurufaanu's reign marked the start of the Utheemu dynasty, a turning point towards a more structured system of governance and a period of reform and organisation, more specifically in defence and education (DIB, 1990, p. 2). During this period, the sultanate became an institution instead of a person, where "tenets of democracy in the form of the consent of the ruled became more evident in the decisions of the sultan" (DIB, 1990, p. 2).

\footnotetext{
${ }^{29}$ According to Hecker (1986), the first contact with the Portuguese was made in 1505 when the islands were visited by Portuguese ships. De Silva (2009) reports that Vicente Sodré's ships had sailed to the Maldives as early as 1502-1503. As the Portuguese interest in the Maldives grew, they made several attempts to dominate the Maldives and were eventually successful in 1558 when they defeated Sultan Ali VI, the Martyr.

${ }^{30}$ After the defeat in 1573, the Portuguese sent more forces to regain the Maldives and the struggle went on for three more years after which the Maldives agreed to pay tribute in return for freedom from interference in internal affairs (de Silva, 2009). The Portuguese once again attempted to overtake the capital Male' in 1631 and 1649, but their futile attacks were driven off (de Silva, 2009).
} 
The second instance of direct occupation of the Maldives was by the Malabars ${ }^{31}$ for roughly four months during 1752. As repression and torture by the Malabars increased, a group of Maldivians led by Dhon Bandarain removed the occupiers (Reynolds, 1975). This event is significant in the Maldivian history because it was the last instance of direct foreign occupation. ${ }^{32}$

Changes in regional powers have also had an effect on the Maldives. The Dutch arrived in Ceylon (Sri Lanka) in 1638 and defeated the Portuguese there in the 1640s (de Silva, 2009). To counter the Portuguese threat the Maldivian sultan secured a tributary relationship with the Dutch in Ceylon (de Silva, 2009), as the Dutch were unwilling to intervene in the Maldives. By 1798 the British had assumed control of Ceylon (Coelho, 1997, p. 51). As domestic disturbances continued in the Maldives, the British feared that the Maldives might seek protection from another foreign power, affecting the British dominance in the region. The Maldives was crippled by bankruptcy, and the "gunboat" diplomacy of the British forced the sultan in 1887 to enter into a protectorate agreement under which the full control of foreign and defence affairs were handed over. The agreement was based on non-interference by the British in the internal affairs of the nation, which is perhaps why the Maldives lacks the same colonial imprint as the rest of South Asia (Maloney, 1976, p. 656). British impact on Maldivian economy, politics and society was therefore minimal compared with the experiences of neighbouring countries (Maumoon, 2002). The lack of foreign influences in the internal matters of the country meant that the political, economic, and social development of the Maldives was virtually immune to foreign influences until the twentieth century, except for some limited contact with Sri Lanka (Phadnis \& Luithui, 1981).

The Maldives' first written constitution was proclaimed on December 22, 1932 and was largely based on customs, conventions, and traditional administrative practices that the country had followed until then (DIB, 1990). With it, the country effectively

\footnotetext{
${ }^{31}$ Malabars came from the south west coast of India and were based in Cochin.

32 The terrorist attack on Male' on November 3, 1988 by Tamil Tigers did not result in occupation of the country. The attackers fled the country the same day after facing fierce resistance from the Maldivian army.
} 
converted to a constitutional monarchy with a majlis ${ }^{33}$ (legislature) and a cabinet of ministers (Maloney, 1976). This was seen as the renouncing of royal prerogatives which had been held for more than 800 years and a touch of democracy from the European countries (Hockly, 1935, p. 139). The constitution came into effect mainly due to a weakened sultan and an unstable political environment in the Maldives (Phadnis \& Luithui, 1985). However, that constitution did not significantly change the authoritarian nature of the political regime that had lasted for centuries (Reynolds, 1975). ${ }^{34}$ Despite the lack of meaningful reform, some argue that, although the system of government was autocratic, most often it was benevolent in nature (Coelho, 1997, p. 51).

In an attempt to bring the Maldives into the modern world, a public referendum was held to decide whether the people wanted a monarchy or a republic. With the consent of the people, the Maldives converted to a republic on January 1, 1953 with Amin Didi elected as its first President (Maumoon, 2002). The new republican constitution gave voting rights to women and provided modern schools with equal opportunities for women, and health facilities and technology such as telephone and power plants were introduced for the first time (Maumoon, 2002). However, continuing political turmoil meant that the situation deteriorated to such an extent that Amin Didi ${ }^{35}$ was deposed in September of that same year (Reynolds, 1975). The short lived first republic ended and the sultanate was re-instated in March 1954 with a new constitution $^{36}$ (Maumoon, 2002). Interestingly the majlis, which mostly consisted of elected members, was retained with powers to override the sultan's veto (Maloney, 1976).

Throughout the internal political turmoil, the British refused to get involved (Maloney, 1976). However, the importance of the Maldives to Britain was magnified

\footnotetext{
${ }^{33}$ Parliamentary elections have been held in the Maldives almost every five years since 1932 .

${ }^{34}$ After further political turmoil, the first constitution was abolished in 1933 and a new constitution was drawn in 1934 (Maumoon, 2002). It was further amended in 1936, 1937, 1942 and 1951.

${ }^{35}$ While Amin Didi was abroad for medical treatment, an uprising against the government took place and the constitution was suspended. Upon his return he was arrested and sentenced to be banished for an attempted coup d'etat, and he died in January 1954 while in banishment (Maumoon, 2002). It is believed he died from the injuries that he sustained when he was mobbed and stoned when he disembarked at the capital Male' (Maloney, 1976).

${ }^{36}$ This constitution was again amended in 1965 and 1967 (Maloney, 1980, p. 202).
} 
during the Second World War when the British used the southern island of Gan as an air and naval base. It also marked the beginning of the end of the on-going smooth relationships between Britain and the Maldives. With the strategic importance of the military base in Gan, the British had negotiated with the Maldivian government to lease Gan Island for 100 years from $1956^{37}$, an agreement that was not popular among some political elites. The rebellion and secession of the three most southern atolls in 1959 marked one of the most difficult episodes that the country had to face during the century and it is believed that there was encouragement by the British for the rebellion (N. Mohamed, $n . d$.). During the negotiations that followed between the Maldivian government and British representatives, an agreement was reached in September 1963 to end the rebellion and re-establish the authority of the Maldivian Government in the southern most atoll of $\operatorname{Addu}^{38}$ (N. Mohamed, n.d.). The head of the rebellion Abdulla Afeef and his family were given political asylum by the British and taken to Seychelles.

Animosity towards the British among the Maldivian public had grown to unprecedented heights as a result of the rebellion. During the negotiations between the British and the Maldivian government held at that time, the Maldivian government formally requested full independence from the British and this was attained on July 26, 1965. The British military base in Gan remained under the previous agreement but the British closed the base and fully withdrew from the Maldives on March 31, 1976 ${ }^{39}$ (Hecker, 1986).

Soon after gaining political independence, the Maldives converted to a Republic once again. In a national referendum held on March 15, 1968, 81\% of the public voted in favour of abolishing the sultanate (Ahmad, 2001). After yet another public referendum, Ibrahim Nasir was elected as President of the Second Republic and

\footnotetext{
${ }^{37}$ This agreement was re-negotiated in 1960 in which Britain's rights over the base were reduced to a period of 30 years (Phadnis \& Luithui, 1981).

38 The southern rebellion atoll of Fuvahmulah surrendered to the Maldivian government on November 1, 1963. Previously the southern atoll of Huvadhoo surrendered after military intervention on January 29, 1962 (N. Mohamed, n.d.).

${ }^{39}$ The British abandoned Gan Island before the expiry of their contract as part of their defence cut and withdrawal from the East (Phadnis \& Luithui, 1981).
} 
sworn into office on November 11, 1968 under a revised constitution ${ }^{40}$ that came into force on the same day. Socio-economic changes by Nasir included the introduction of tourism in the early 1970s, which resulted in the opening of the country to the outside world thereby bringing many changes to the traditional way of life (Maumoon, 2002). Nonetheless, political reform was almost negligible, resulting in a continuation of political turmoil. One such example was the removal and banishment ${ }^{41}$ of Prime Minister Ahmed Zaki in 1974 on the grounds of mismanagement and favouritism towards relatives, though the actual reasons may have been the disputes over the control of state industries (Phadnis \& Luithui, 1981).

Consolidation of political power also continued during this period. Under the 1968 constitution, the majlis was elected for five years and the majlis nominated a candidate for the presidency that went to a public referendum for acceptance or rejection (Maloney, 1976). The constitution gave the president far reaching powers, including the ability to appoint eight members ${ }^{42}$ to the majlis ${ }^{43}$, as well as the speaker of the majlis (Maloney, 1976) and the chief justice. Further centralisation of authority included appointment of Atoll Chiefs by the central government ${ }^{44}$, abolition of the Office of Prime Minister through a constitutional amendment, and abolition of several ministries to bring them under the PO (Maloney, 1976, p. 668). It was "felt that the political unity of the country can only be assured by a well-ordered chain of command with which is mingled a generous dose of fear" (Maloney, 1976, p. 659). Dissent towards President Nasir grew and he was accused of mismanagement of government funds as well as abuse of power which eventually

\footnotetext{
${ }^{40}$ This constitution was further amended in 1970, 1972 and 1975 (Maloney, 1976).

${ }^{41}$ Banishment is an ancient practice where one is sent to a remote inhabited island without his/her family where he/she has to find a place to live and earn a living. In traditional times those who were banished resorted to fishing but it was almost impossible to escape from the island. The length of the banishment can vary, with lengthy terms being imposed in the case of political dissidents. In the past, most politically influential people experienced banishment at one time or another during their lifetime (Maloney, 1976). That includes President Maumoon Abdul Gayoom (see section 4.3.2) as well. Although, the penal code of 1968 which contains banishment as a sentence is still valid, banishment is rarely handed now.

${ }^{42}$ Prior to the constitutional amendments of 1975 , these eight members were elected to the majlis from the capital Male' (Maloney, 1976). This constitutional change was a result of centralisation of powers of the president during 1975. The full majlis comprised 48 members.

${ }^{43}$ During this period, the majlis was not seen as a threat to the government as its members remained in fear and some had even been banished. It met about three times a year (Maloney, 1976).

${ }^{44}$ Until 1975 the Atoll Chief was elected from the atoll committee which was itself an elected body (Maloney, 1976). Elections of atoll committees started in 1964 (Maloney, 1980, p. 186).
} 
resulted in his departure from office in 1978 and self-imposed exile in Singapore shortly afterwards.

\subsubsection{Political system: 1978 to 2003 .}

The taking of office by the second president of the Second Republic, Maumoon Abdul Gayoom, in 1978 marked the beginning of a new chapter in the Maldives. Although social and economic sectors were changing and growing rapidly, democratic reforms were slow and insignificant. Even though the president convened a constitutional assembly (People's special majlis) on November 29, 1980 to amend the 1968 constitution, it took a further 17 years to complete the new constitution. Moreover, the constitution that came into effect from January 1, 1998 lacked the fundamental aspects required in a modern democracy such as the provision for multiparty politics and was arguably a continuation of the 1968 constitution. Table 4.2 shows a comparison of the main components of 1968 (including the amendments of 1970, 1972, and 1975) and 1998 constitutions.

Table 4.2: Comparison of main components of 1968 and 1998 constitutions

\begin{tabular}{|c|c|c|}
\hline & 1968 constitution & 1998 constitution \\
\hline Presidential powers & $\begin{array}{l}\text { Head of state and } \\
\text { government; supreme } \\
\text { authority in propagating the } \\
\text { tenets of Islam. } \\
\text { Appoint/dismiss speaker of } \\
\text { people's majlis. }\end{array}$ & $\begin{array}{l}\text { Powers of the } 1968 \\
\text { constitution retained. } \\
\text { Additional powers included: } \\
\text { highest authority in } \\
\text { administering } \\
\text { appoint/dismiss chief justice, } \\
\text { deputy of the people's } \\
\text { majlis, atoll chiefs, judges, } \\
\text { auditor general and the } \\
\text { commissioner of elections. }\end{array}$ \\
\hline Presidential election & $\begin{array}{l}\text { People's majlis decides on a } \\
\text { presidential candidate by a } \\
\text { secret ballot. The chosen } \\
\text { name goes for a public } \\
\text { referendum. President chosen } \\
\text { for a five year term. }\end{array}$ & $\begin{array}{l}\text { Almost same as 1968. Only } \\
\text { difference was that any } \\
\text { person who fulfils the } \\
\text { criteria can apply after which } \\
\text { the people's majlis decide on } \\
\text { one candidate by a secret }\end{array}$ \\
\hline
\end{tabular}




\begin{tabular}{|c|c|c|}
\hline & & ballot. \\
\hline People's majlis & $\begin{array}{l}\text { Main mandate was to pass } \\
\text { legislations. Comprised } 48 \\
\text { MPs; eight appointed by the } \\
\text { president, } 40 \text { elected }^{45} \text {. Five } \\
\text { year term limit. Provision for } \\
\text { questioning ministers and } \\
\text { passing motion of no } \\
\text { confidence on them. } \\
\text { Impeachment of the president } \\
\text { also possible. }\end{array}$ & $\begin{array}{l}\text { Same as } 1968 \text {. Only } \\
\text { difference was an additional } \\
\text { two elected MPs that was } \\
\text { due to a change in the } \\
\text { administrative structure of } \\
\text { the archipelago. }\end{array}$ \\
\hline People's special majlis & $\begin{array}{l}\text { Mandated to amend the } \\
\text { constitution. Convening and } \\
\text { dissolution vested with the } \\
\text { president. Composition } \\
\text { included: members of the } \\
\text { cabinet of ministers; all } \\
\text { members of the people's } \\
\text { majlis; } \\
\text { elected/appointed separately } \\
\text { to the same composition of } \\
\text { the people's majlis. } \\
\text { Furthermore, laws changing } \\
\text { the value of the currency and } \\
\text { laws that impair the rights of } \\
\text { the administration or citizens } \\
\text { passed by people's special } \\
\text { majlis. }\end{array}$ & $\begin{array}{l}\text { Almost the same as } 1968 \text {. } \\
\text { Only difference was that the } \\
\text { only mandate was to amend } \\
\text { the constitution. }\end{array}$ \\
\hline Courts & $\begin{array}{l}\text { A single reference regarding } \\
\text { the judiciary. Article } 85 \\
\text { states "The administration of } \\
\text { justice and Shariath shall be } \\
\text { conducted by a body } \\
\text { appointed by the President of } \\
\text { the Republic". }\end{array}$ & $\begin{array}{l}\text { High court was the highest } \\
\text { court. President determined } \\
\text { the number of judges on the } \\
\text { bench } \\
\text { appointed/dismissed all of } \\
\text { them. Lower courts also } \\
\text { operated in the same manner. }\end{array}$ \\
\hline
\end{tabular}

${ }^{45}$ Two MPs from each of the 19 atolls and two MPs from Male'. 


\begin{tabular}{|l|l|l|}
\hline & & $\begin{array}{l}\text { A minister assigned by the } \\
\text { president had the authority to } \\
\text { issue directives and orders } \\
\text { concerning the } \\
\text { administration of courts and } \\
\text { the conduct of judges. }\end{array}$ \\
\hline Civil liberties & $\begin{array}{l}\text { Freedom of expression and } \\
\text { association granted, unless } \\
\text { prohibited by law in the } \\
\text { interest of protecting the } \\
\text { sovereignty and maintaining } \\
\text { public order and of protecting } \\
\text { the basic tenets of Islam. }\end{array}$ & \\
\hline
\end{tabular}

Both constitutions were silent on the crucial issue of the clear separation of powers between the different arms of the state, and the strong hierarchical nature of politics and administration remained unchanged. Secondly, there were no term limits on the office of the president. Opponents claimed that this was the reason why the former President Gayoom was re-elected for six consecutive terms ${ }^{46}$ : he had been successful in retaining the majority of his supporters in the parliament. Misra (2004, p. 135) argues that although the Maldives managed to change from a sultanate to a republic, sultanism existed under a new guise. Presidential powers were similar to those of the sultanate before the founding of the republic. A third major issue was a lack of restrictions on ministers and public servants simultaneously becoming MPs. In the past several ministers and public servants had been appointed or elected to the majlis, raising conflict of interest issues for government accountability by further blurring the separation of powers between executive and legislature.

This absence of the basic tenets of modern democratic reforms in the 1998 constitution meant that the eagerness among the general public and expectant elites for greater political freedom and political rights continued rising and there was growing frustration with the slow pace of political evolution. In the early 1990s,

\footnotetext{
${ }^{46}$ Former President Gayoom was elected in 1978 with $92.96 \%$ of the popular votes, in 1983 with $96.62 \%$, in 1988 with $96.4 \%$, in 1993 with $92.76 \%$, in 1998 with $90.9 \%$ and in 2003 with $90.28 \%$ of the popular vote.
} 
several popular political magazines were accused of inciting violence and were banned. In February 2001, a group of 42 intellectuals and prominent social figures submitted a request to register the Maldivian Democratic Party (MDP) as a political party, but this request was denied on the grounds that the constitution did not contain provisions regarding political party registration and formation. Despite the setback, prominent opposition figures operated the MDP in exile from Colombo, Sri Lanka. Frustration eventually boiled over in September 2003, triggered by a specific event (see section 4.4.4). One interviewee described this event as a "revolution" that had "no turning back", forcing the government to pursue democratic reforms (Interviewee FO4).

\subsubsection{Democratic process: 2003 to 2008 .}

Since 2003, the Maldives has undergone unprecedented political changes. A key trigger to "real" reform was 2003 civil unrest in the capital (see section 4.4.4) which placed pressure on government to reform the governance of the country. For the first time, the Maldives was on the path towards a multi-party democracy. In June 2004, President Gayoom announced his vision for constitutional reform that would lead to a multi-candidate election process. These reforms also included putting significant constraints on the powers of the political executive that had until then controlled unprecedented powers (see table 4.2). In a major policy speech delivered on June 9, 2004, President Gayoom said "increasing the choice for the people in electing a president of the Republic and the further separation of powers are among the ideas for constitutional reform that I have proposed .... Likewise, our political system must further incorporate modern democratic practices" (cited in The National Democratic Institute for International Affairs, 2004, p. 10). The specific reform components included:

a) Strengthening the system of governance;

b) Promoting and strengthening the protection of human rights;

c) Enhancing the independence of the judiciary;

d) Developing the multiparty political system;

e) Strengthening the civil service;

f) Modernising the electoral system; 
g) Enhancing the role of the media; and

h) Strengthening key institutions. (Alam \& Jasimuddin 2006, p. 11)

The president convened the people's special majlis in July 2004 to formulate a new constitution based on multi-party democratic principles. This was a complicated task and several setbacks were encountered due to distrust between political rivals. Additionally, the public continued to demand immediate political reform. In August 2004, thousands demonstrated in Male' (also discussed in section 4.4.4). To defuse the dissent, government made some concessions, including establishment of Police as a civilian organisation independent of the military (Yoosuf, 2004) and the appointment of finance and defence ministers ("Defence Minister Kamashaai," 2004) - portfolios held until then by the president. These changes came after continued pressure on the president to give up some of his powers.

Parliament's unanimous vote on June 2, 2005 to permit the formation and operation of political parties ("Maldives MPs Back Democracy," 2005) resulted in immediate formation of DRP (Dhivehi Rayyithunge Party) led by President Gayoom and the MDP led by the opposition leader Mohamed Nasheed, and provided a foundation for the freedom of association and freedom of expression that transformed the political spectrum entirely. ${ }^{47}$ Ironically, permission for the operation of political parties was given under the same 1998 constitution that was previously deemed incompatible with political parties.

In addition to the formulation of a new constitution, other notable governance reforms during this period included the "Roadmap for the Reform Agenda" in March 2006 which provided a timeframe for the reforms announced in June 2004. The MDP argued that the roadmap announced by President Gayoom was "a desperate attempt to buy time for his political survival" (Suryanarayan, 2009, p. 196). However, the provision for a statutory CSC in that roadmap outlined the importance of a CS for the progression of democratic reforms in the Maldives. Significant progress on the CS reform began in October 2005 when a parliamentarian aligned

\footnotetext{
${ }^{47}$ Several other parties have subsequently been formed but these two parties were largest in terms of membership as of March 2012.
} 
with the government submitted a CS bill, which became law in May 2007 (detail discussion in sections 6.2 to 6.7 ).

Constitutional reform was further delayed by deep divisions among members of the special majlis over whether a presidential or parliamentary system of government should be enshrined in the constitution. The government backed a presidential form of government while the opposition MDP backed a parliamentary form, and the impasse was surmounted when the matter was referred to a public referendum at which support for a presidential system of government gained $62 \%$ of the vote. These delays in formulating the constitution meant that the deadlines set under the Roadmap of Reform were not achieved and the new constitution was completed and ratified on August 7, 2008, after more than four years of political bickering, strikes, and unrest.

The 2008 constitution is significantly different from all previous constitutions. The three arms of the state, executive, legislature, and the judiciary have been made independent of each other. Significant constraints were put on the powers of the political executive. Additionally, the CSC was made a constitutional body (see table 4.3), that would manage a CS as the administrative arm of the executive - with relative separation from the political executive. Schneier (2006, p. 105) states that embedded in most contemporary constitutions are particular institutions empowered to perform roles that are isolated from the direct control of the legislature or the executive. Such overseeing bodies are also established in the Maldives. Furthermore, under the new constitution, city, atoll, and island councils are elected by the constituencies. Rights of citizens have been codified as never before. Table 4.3 provides a comparison of the main components of the 1998 and 2008 constitutions.

The negotiations over the constitutional reform in the Maldives took into account the protection of the interests of small scattered communities as well. The previous constitutions had the provision for two elected MPs from each atoll irrespective of the population size (see table 4.2). The 2008 constitution replaced this provision by dividing each atoll into a number of constituencies based on the population, but with a minimum number of MPs from each atoll. That meant that atolls with larger 
population would have more MPs. In the meantime, it also meant that the entire population, irrespective of the size or insularity will also have representation.

Decentralisation of powers to the elected city, atoll and island councils was also an important component of the reform agenda. Once again, islandness was a factor in the considerations on the architecture of these councils. For instance, each island would have a minimum number of councillors and all the islands in the atoll would be included in the composition of the atoll councils. These councils were given legal powers over municipal and development functions within their constituencies. However, these powers did not include making decisions on employment of civil servants working for those councils (see section 7.2.2).

Table 4.3: Comparison of main components of 1998 and 2008 constitutions

\begin{tabular}{|c|c|c|}
\hline & 1998 constitution & 2008 constitution \\
\hline Powers of state & $\begin{array}{l}\text { A high degree of } \\
\text { concentration of power in } \\
\text { the hands of the president. }\end{array}$ & $\begin{array}{l}\text { Powers of the state divided } \\
\text { among the president, } \\
\text { parliament, judiciary, and } \\
\text { several statutory bodies. }\end{array}$ \\
\hline Presidential election & $\begin{array}{l}\text { Five year term, no term } \\
\text { limits. A public referendum } \\
\text { after the majlis chooses a } \\
\text { candidate. }\end{array}$ & $\begin{array}{l}\text { Five year term. Maximum of } \\
\text { two terms, whether } \\
\text { consecutive or otherwise. All } \\
\text { applicants go directly to a } \\
\text { public vote. }\end{array}$ \\
\hline People's majlis & $\begin{array}{l}\text { Comprising appointed and } \\
\text { elected members. } \\
\text { Speaker/deputy appointed by } \\
\text { the president. }\end{array}$ & $\begin{array}{l}\text { All members elected. } \\
\text { Speaker/deputy elected by the } \\
\text { MPs. Additional functions } \\
\text { include: amending the } \\
\text { constitution, making the } \\
\text { executive power accountable, } \\
\text { and appointment/dismissal of } \\
\text { senior officials of statutory } \\
\text { bodies in accordance with the } \\
\text { laws. }\end{array}$ \\
\hline Courts & $\begin{array}{l}\text { President appoints and } \\
\text { dismisses all judges. }\end{array}$ & $\begin{array}{l}\text { Judicial power vested in the } \\
\text { Supreme Court, the High }\end{array}$ \\
\hline
\end{tabular}




\begin{tabular}{|c|c|c|}
\hline & & $\begin{array}{l}\text { Court, and the Trial Courts. } \\
\text { Chief justice and the judges of } \\
\text { the Supreme Court are } \\
\text { appointed by the president } \\
\text { after consulting the judicial } \\
\text { service commission (JSC) and } \\
\text { confirmation of appointment } \\
\text { by the people's majlis. All } \\
\text { other judges appointed by } \\
\text { JSC. Judges can be removed } \\
\text { from the post if JSC finds a } \\
\text { judge grossly incompetent or } \\
\text { guilty of gross misconduct. In } \\
\text { either case the matter must be } \\
\text { referred to the people's majlis } \\
\text { where two thirds of the MPs } \\
\text { present must vote in favour of } \\
\text { the judge's removal. }\end{array}$ \\
\hline Civil liberties & $\begin{array}{lll}\text { Though } & \text { granted } & \text { in } \\
\text { constitution, limitations in } \\
\text { practice. }\end{array}$ & $\begin{array}{l}\text { Additional rights include: } \\
\text { right to freedom of peaceful } \\
\text { assembly without prior } \\
\text { permission of the state; right } \\
\text { to establish and participate in } \\
\text { the activities of political } \\
\text { parties; and right to strike in } \\
\text { protest. }\end{array}$ \\
\hline Statutory bodies & $\begin{array}{l}\text { No provision for statutory } \\
\text { bodies. }\end{array}$ & $\begin{array}{l}\text { Provisions of statutory bodies } \\
\text { of JSC, elections commission, } \\
\text { civil service commission, } \\
\text { human rights commission, } \\
\text { anti-corruption commission, } \\
\text { auditor general, and } \\
\text { prosecutor general mentioned. } \\
\text { Also provision for elected } \\
\text { councils with decentralised } \\
\text { powers. }\end{array}$ \\
\hline
\end{tabular}


Ratification of the 2008 constitution paved the way for a new breed of politics in the Maldives. In the face of the upcoming election in October 2008, prominent ministers and political figures resigned from the Gayoom administration and several opposition political parties were established to challenge the 30-year rule of Gayoom. However, the main threat to his administration still came from the MDP which continued to be the most vocal of the opposition parties (Suryanarayan, 2009, p. 196). The presidential election held on October 8, 2008 did not reveal a clear winner. Among the main contenders, Gayoom received $40.63 \%$ of the votes, Mohamed Nasheed 25.09\%, Hassan Saeed 16.78\%, and Gasim Ibrahim 15.32\% (Elections Commission, 2008a). A second round of voting took place on October 29, 2008 between the two candidates who obtained the highest number of votes during the first round. During campaigning for the second round, Hassan Saeed and Gasim Ibrahim pledged their full support to Mohamed Nasheed. The second round of voting revealed Mohamed Nasheed as a clear winner with $54.21 \%$ of the votes (Elections Commission, 2008a). Mohamed Nasheed, commonly referred to as Anni, became the first president under a democratic constitution and was sworn into office on November 11, 2008.

\subsection{Causes of democratisation}

There is rarely a single reason for a nation to pursue the path towards democracy and the Maldives is no exception to this generalisation. It could be argued that a combination of socio-historic elements combined with developments, or even lack of developments, in various facets of the society led to the democratisation of the Maldivian polity. This section examines a number of such factors that were significant for democratic reforms in the Maldives. It follows a similar structure as Chapter Two, section 2.2.2 examining the influences on democratisation of political elites, mass movements, societal groups, significant incidents, economic and social development, globalisation and media, and the international community.

\subsubsection{Political elites.}

Traditionally, local elites in the Maldives were boat owners or lessees of uninhabited islands which placed them in a financially sound position (Maloney, 1980). It was 
also common that such elites had political connections with elites in Male'. In the past, those with such connections were able to land political jobs at island or atoll level (Maloney, 1980). With modernisation, the power base of the traditional elites has faded significantly. Nonetheless, some have been able to maintain their elite status due to the economic benefits flowing from their past privileges. For those elites who backed democratic reforms, their status was important in financing antigovernment protests.

The power base of the elites was centred in the capital where the traditional class system comprised the four main divisions ${ }^{48}$ of royalty, hereditary aristocracy, titled aristocracy, and commoner. Since these classes were abolished in the early $1950 \mathrm{~s}$ (Maloney, 1980), associated titles have become rare and simply symbolic when used as surnames. However, the abolition of sultanistic dynasties or class systems did not remove the influence that a few elite families had on the Maldives' political sphere. As Parmanand (1997, pp. 117-118) notes, "Maldivian politics is dominated by an elite drawn from a few influential families and they frequently command considerable support among the population”. Change to a republic in 1953 was considered simply a continuation of the old practices albeit in a different shell. The influence of the elite families continued from the First Republic of 1953 and was clearly visible in Gayoom's reign. In this regard, Faber (1992, p. 139) states that government and businesses remained "in the hands of a small côterie of privileged families in Male' which everyone can name". Indeed Gayoom was often blamed for maintaining a highly centralised political system which had its roots in the oligarchic structure of the sultanate (Parmanand, 1997, p. 117). Nonetheless, these power bases too were shaken in the last couple of years of the Gayoom's presidency because several of his trusted ministers defected to the opposition.

For such defectors as well as emerging elites that included political dissidents, the effects of modernisation, development, and globalisation generated an ideal opportunity to tap into power. As one interviewee said, the "democracy market" was the biggest market that could be exploited by those elites eager to gain a share of greater power for themselves (Interviewee FO5). The election of several vocal

\footnotetext{
${ }^{48}$ For detail refer to Maloney (1980, p. 300).
} 
opposition MPs to the majlis during 2005 and special majlis in 2004 contributed to continuous and growing pressure on the government to speed up the reform process. Although MPs supporting the government had a majority in both majlis, compromises were often made with the opposition to get the bills passed as well as in formulating the constitution. The introduction of political parties during 2005 also was crucial because freedom to associate turned out to be a driving force in politicising the general public, as never before. This new-found freedom brought masses to political rallies, the impact of which was always used by political elites in their attempts to gain the upper hand in political debates.

The movements led by the MDP and the initiatives of President Gayoom were both pivotal in bringing about the multi-party election of 2008. The MDP played a major role in convincing the government and the public, at times through public demonstrations, that democratic change was necessary to ensure the ongoing development of the nation. President Gayoom and a group of his senior officials were also instrumental in designing a road towards democracy that included radical compromises. In the words of a former government official, "there was a willingness on the part of the former government ${ }^{49}$ to bring about certain changes to the way in which the country was governed" (Interviewee FO6). Therefore, the impact the elites had through institutions such as the government, majlis, special majlis and the political parties was crucial in maintaining momentum and guiding the general public through the democratisation process.

\subsubsection{Mass movements.}

Though the Maldives continues to remain an "elite-dominated democracy",50 despite the transition, demand by the general public to have a voice in the political arena has been increasing for some years now. Especially during the latter years of Gayoom's administration, government was continuously blamed for not spreading the development achieved in the capital island to remote corners of the archipelago. The

\footnotetext{
${ }^{49}$ Reference is made here to the Gayoom administration.

${ }^{50}$ Sørensen (1998, p. 81) defines elite-dominated democracies as systems in which traditional rulers remain in control, even if pressured from below, and successfully use strategies of either compromise or force - or some mix of the two - to retain at least part of their power.
} 
economic divide was clearly visible: "the gap between the rich and the poor was becoming too obvious" (Interviewee GO7). When a 30-year rule had been unable to narrow the developmental gap, a simple change of regime appeared to be a popular solution, and this was openly welcomed by a majority of the electorate. A growing number of individuals were hopeful that they could get a share of the economic fortunes of the nation which were being controlled by a few elites.

Allegations were also made of abuse of power and state resources by Gayoom's administration despite the nation's economic development under his rule. The inability to develop the outlying atolls combined with an inability to deal properly with cases of abuse of power also became building blocks for the arguments of the opposition that was advocating regime change. A heightened awareness and shift in public perception eventually led to agreement by the majority of the population that there was a need for a regime change: "any change" as some put it (personal observation).

Limited room for political participation was also seen a shortcoming prior to the start of democratic reforms. The traditional oligarchic political structure combined with a constitution that allowed limited political participation had prevented a large number of individuals from aspiring to political office. With the advancements in socioeconomic spheres of public life, the desire to have a greater say in the functioning of the state was evident amongst an educated and young population that was prepared to pursue democratic changes. The incremental reforms of the past were not acceptable anymore. A radical change was demanded, for which the ruling elite had no effective response. A politician described it thus:

What has [been] achieved in the past few years has been a more contemporary form of democratic process, which means a certain form of elections, certain independent institutions, and certain formalities of doing things. So it means there is this urge and need that was seen by the majority of Maldivians that a previous type of democracy or form of representation was not good enough or was not sufficient enough. So they wanted to replace it with a much more representative, much more elective mode of democracy. (Interviewee PL2) 
The right to be politically active was increasingly viewed as a fundamental human right, a relatively new ${ }^{51}$ concept for the general public. As a result of the on-going changes, freedom of assembly and freedom of expression without fear of imprisonment were seen as fundamental rights by the public. The rise in such demands was driven by the rise in self-expression values in the Maldives.

\subsubsection{Societal groups.}

In the wider sense, societal groups can include CSOs as well as political parties. Though Maldives have traditionally seen active CSOs at island level focused on island development, only a few operated at national level. A lack of political plurality also meant that almost no CSO operated in promoting democracy. However, the introduction of political parties in June 2005 paved the way for political activism by such parties. A significant proportion of the population opted to join political parties (refer to table 4.9). Political forums and open public debate soon became a common occurrence. The political protests and strikes that followed were led directly by political parties, especially by MDP, often credited as a leader in the democratisation process (Interviewees FO2, FO4, FO6, FO10, GO3, GO6, GO7). As a result, the role of political parties in galvanising the general public was considered instrumental during the transition phase.

\subsubsection{Significant incidents.}

Although incremental reforms had been undertaken in the Maldives over many years, public frustration eventually boiled over in 2003. In September 2003, a prisoner at Maafushi Island Jail was tortured and beaten to death by the guards. The death was followed by a major uprising at the jail, which ended after three inmates were shot dead and several others injured. Once news of these incidents reached the shores of Male', huge numbers of disgruntled people took to the streets in protest. The government opted not to use force against the protesters, resulting in a number of government buildings and properties being torched. The government immediately established a Presidential Commission to investigate the incidents that had unfolded

${ }^{51}$ The first Human Rights Commission of the Maldives was established on December 10, 2003. 
in the jail. Soon after, in October 2003, a presidential election was held in which Gayoom was re-elected for a sixth consecutive term. In his speech delivered on November 11, 2003, President Gayoom announced an unprecedented and wideranging reform programme designed to usher in a modern liberal democracy with strengthened human rights safeguards.

Although the Constitutional Assembly was convened in July 2004, the public was demanding almost immediate political reform. A clear indication of this demand came in August 2004 when thousands demonstrated in the capital Male'. As this protest was one of the biggest in the modern era, it sent a very strong message to the government. The protest ended with unrest after the security forces dispersed the crowd. The government declared emergency rule ${ }^{52}$ and arrested several opponents but protests and political rallies became a common phenomenon of the Maldivian polity.

\subsubsection{Economic developments.}

The Maldives has achieved significant economic prosperity in the last few decades. Tuna fish and tourism have made the Maldives prosperous (A. Whitehead, 1997). Traditionally, fishing was the main source of income for the majority of the citizens, with over $80 \%$ of the population engaged in fishing and related activities (Phadnis \& Luithui, 1985, p. 15). However, the introduction of tourism in the 1970s transformed the nation - from 325 visitors in 1962 (Hecker, 1986), to 74,163 visitors in 1983 (MPND, 2005a), to 683,012 by the end of 2008 (DNP, 2009). This came after the Maldives was included among the poorest of island developing countries and among the 20 poorest countries in the world in 1978 (Phadnis \& Luithui, 1985, p. 53). The progressive achievements of the nation are evident as GDP increased from US\$158 million in $1985^{53}$ to US\$1483 million in $2008^{54}$, and GDP per capita increased from US\$879 in $1985^{55}$ to US\$3799 in $2008^{56}$ (DNP, 2011; MPND, 2005a). Among the

\footnotetext{
${ }^{52}$ Emergency rule was declared for the capital and the vicinity. It lasted from August 13, 2004, 3:20 p.m. to October 10, 2004, 6:00 p.m.

${ }^{53}$ Based on the 1995 Constant Basic Price

${ }^{54}$ Based on the 2003 Constant Basic Price

${ }^{55}$ Based on the 1995 Constant Basic Price
} 
countries in the South Asia region, GDP per capita of the Maldives is the highest (De Alwis, 2009). For the period 1985-2008, GDP growth rate has averaged $9.11 \%$ per annum $^{57}$ (DNP, 2011; MPND, 2005a), with 2005 being the only year with a negative trend. ${ }^{58}$ Table 4.4 summarises the trends in economic development.

Table 4.4: Trends in economic development

\begin{tabular}{|c|c|c|c|}
\hline Year $^{59}$ & $\begin{array}{c}\text { GDP } \\
\text { (\$US million) }\end{array}$ & $\begin{array}{c}\text { GDP per } \\
\text { capita (\$US) }\end{array}$ & $\begin{array}{c}\text { Annual GDP } \\
\text { growth rates } \\
(\%)\end{array}$ \\
\hline 1985 & 158.4 & 879 & 15.4 \\
\hline 1990 & 262.1 & 1229 & 16.9 \\
\hline 1995 & 601 & 2284 & 7.8 \\
\hline 2000 & 872 & 2915 & 4.8 \\
\hline 2005 & 973 & 2873 & -7.1 \\
\hline
\end{tabular}

Source: DNP (2011); MPND (2005a)

Despite the economic achievements, the benefits were not felt significantly in the atolls and a considerable disparity of economic and social progress was visible between Male' and the rest of the country (Sathiendrakumar \& Tisdell, 1989; also see Faber 1992, p. 139). Consequently the message of democracy was well-received by those islanders - perhaps for instrumental reasons - who felt that the fruit of economic developments should also be visible in the islands.

Given the relative economic benefits at the national level, many did not have to worry about daily survival needs. As a result, people's aspirations started to focus on higher needs such as greater human rights and political rights. As Lipset (1959, p.

\footnotetext{
${ }^{56}$ Based on the 2003 Constant Basic Price

${ }^{57}$ GDP growth rate for the period 1985 to 2002 is based on the 1995 Constant Basic Price while growth rate for the period 2003 to 2008 is based on the 2003 Constant Basic Price.

${ }^{58}$ The main reason for the negative growth in 2005 was the devastating impact of the Boxing Day Tsunami of 2004. It was estimated that the total damage from the tsunami was US\$304 million or $35 \%$ of GDP, excluding the damage to tourist resorts. (MPND, 2005b).

${ }^{59}$ GDP and GDP per capita for year 1985 to 1990 are based on the 1995 Constant Basic Price while year 1995 to 2005 is based on the 2003 Constant Basic Price. Annual GDP growth rate for year 1985, 1990 and 1995 is based on the 1995 Constant Basic Price, while 2000 and 2005 is based on the 2003 Constant Basic Price.
} 
83) points out, when there is increased income and greater economic security among the lower strata of the society, it allows them to develop more complex and gradualist views of politics. Therefore, economic development in the Maldives has arguably been one of the driving forces that contributed to the democratisation process.

\subsubsection{Social developments.}

There were also significant improvements in the social sector during the last few decades. For instance, the life expectancy at birth for both sexes increased from 46.5 years in 1977 (Shaljan, 2004) to 74 years in 2008, with the average South Asian life expectancy being 65 years in 2008 (World Health Organization [WHO], 2010). Remarkable successes have also been achieved in the control of communicable diseases (WHO, 2008). Nonetheless, due to the high cost of providing advanced medical facilities to the geographically dispersed small population bases, these services were available only in Male' and bigger population centres, and patients from outer islands commonly had to travel to the capital Male' for treatment. With increasing revenue generated by the government, demand increased for better and more advanced services in the atolls. The government's inability to adequately address such grievances was a factor in the demands by the general population for a radical change in the governance of the nation.

The education sector witnessed the most radical development. In the early twentieth century, formal education was confined to the capital and a few islands, while the rest had locally-run, informal schools called edhuruge. The elites who controlled both the state and the wealth of the nation mostly sent their children to Sri Lanka for schooling, in an attempt to groom them as future leaders (Reynolds, 1975). The introduction of English instruction in state schools in 1962 (Ibrahim, 1998, p. 23), provided the opportunity for children from non-elite families to also go abroad for study through scholarships.

The achievements in the education sector are significant. Access to primary education increased from less than $30 \%$ during the 1970s (WB, 1996, p. 1) to $100 \%$ net enrolment in 1998 (WB, 2007, p. 1). The transition rate from primary to lower 
secondary stood at $88 \%$ in 2005 (WB, 2007, p. 9). The adult literacy rate for 15 years and above reached $98.2 \%$ in 2006 (MPND, 2008a).

The absence of a university in the Maldives until recently ${ }^{60}$ meant the only option for tertiary education was to venture overseas. This trend accelerated significantly, as various projects were launched by the government with the financial assistance of donor agencies to develop professionals by sending locals overseas for higher education. Along with donor scholarships, corporate funding and private funding, the number of graduates increased exponentially within a couple of decades. Figure 4.2 shows the overseas scholarships awarded by the government for the period 1995 to 2008. As these statistics do not include students studying through corporate funding or private funding, the actual figures are believed to be much higher. The scholarships awarded by the government include those funded by three WB Education and Training Projects aimed at financing overseas fellowships for postsecondary education to improve the national skills shortages. According to the WB (1996), as a result of its first project, the number of post-secondary graduates in the country increased from less than 200 graduates in 1989 to almost 500 in 1996 (table 4.5 outlines the number of scholarships awarded under all the WB projects, which includes undergraduates, graduates, and professional training).

Table 4.5: Fellowships awarded by the World Bank training projects

\begin{tabular}{|c|c|c|}
\hline Project 1 (1989-1995) & Project 2 (1995-2000) & Project 3 (2000-2007) \\
\hline 284 fellowships & 277 fellowships & 321 fellowships \\
\hline
\end{tabular}

Source: WB (1996, 2001, 2007)

${ }^{60}$ The first university in the nation, the Maldives National University, was established on February
$20,2011$. 
Figure 4.2: Government overseas scholarships awarded (1995-2008)

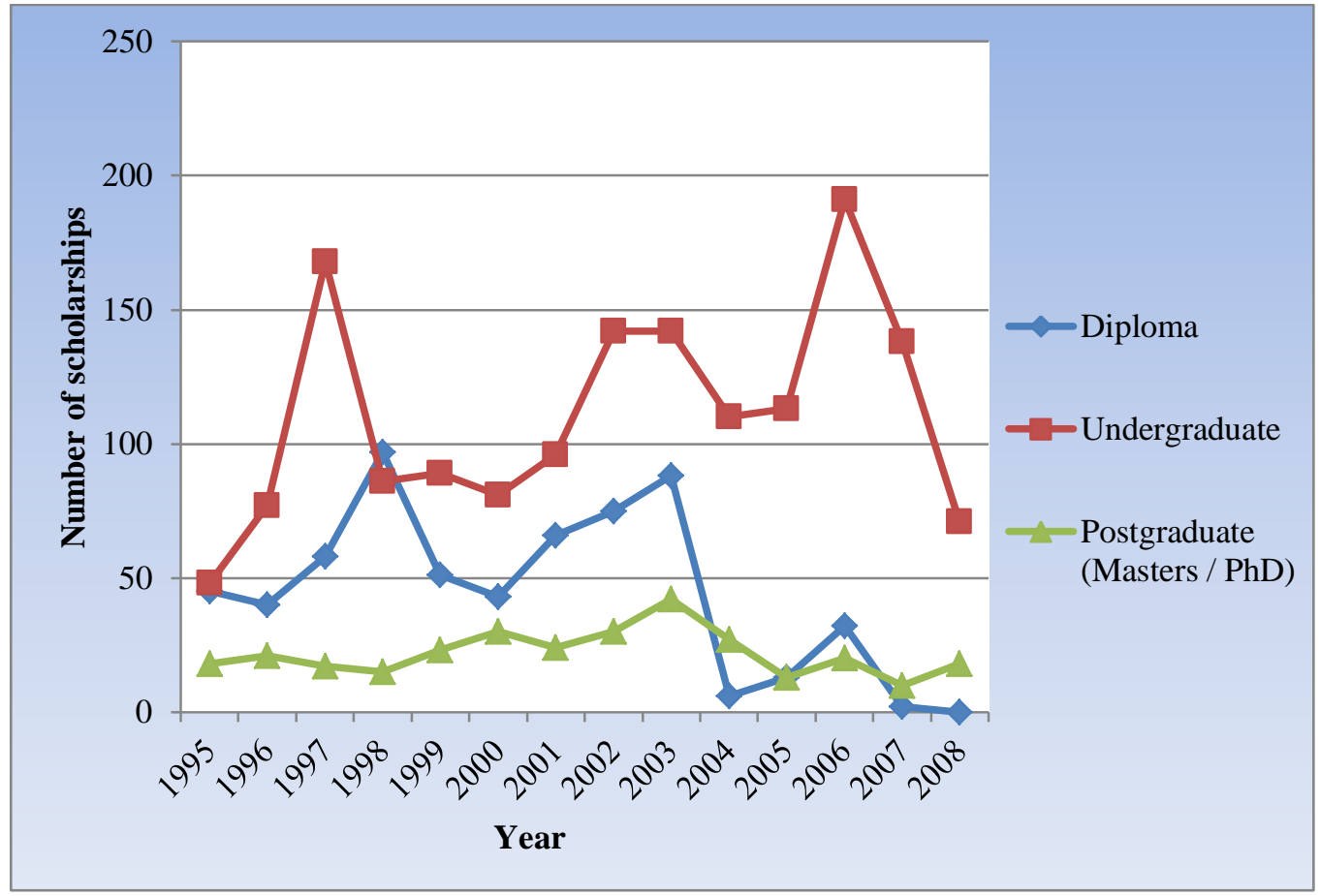

Source: DNP (2010); MPND (2004)

Most students who studied abroad (often in countries with developed democratic systems such as Australia, Canada, New Zealand, and the United Kingdom) returned to the Maldives after completing their studies (Interviewees CV1, FO5, FO7, FO10, GO3, MD1, PL1): "Their aspirations and visions for the nation are different from the existing scenario" (Zaki \& Parakh, 2008, p. 72). A large number of graduates worked in government organisations and lobbied for governance reform. The pressure from inside the government sector was complemented by the demographic changes of the growing portion of youth who were educated and open to information and ideas from abroad made possible by developments in mass media and the spread of the internet.

The demographic change in the population over the last few decades is also significant. The growth in the youth population has been considerable, and during democratisation process the opposition succeeded in playing a "change" card to that young population who had not seen a leader other than Gayoom for 30 years. Figures 4.3 and 4.4 show the population pyramid for the years 1985 and 2006, revealing a significant jump in the age group of 15 to 40 years. 
Figure 4.3: Population pyramid 1985

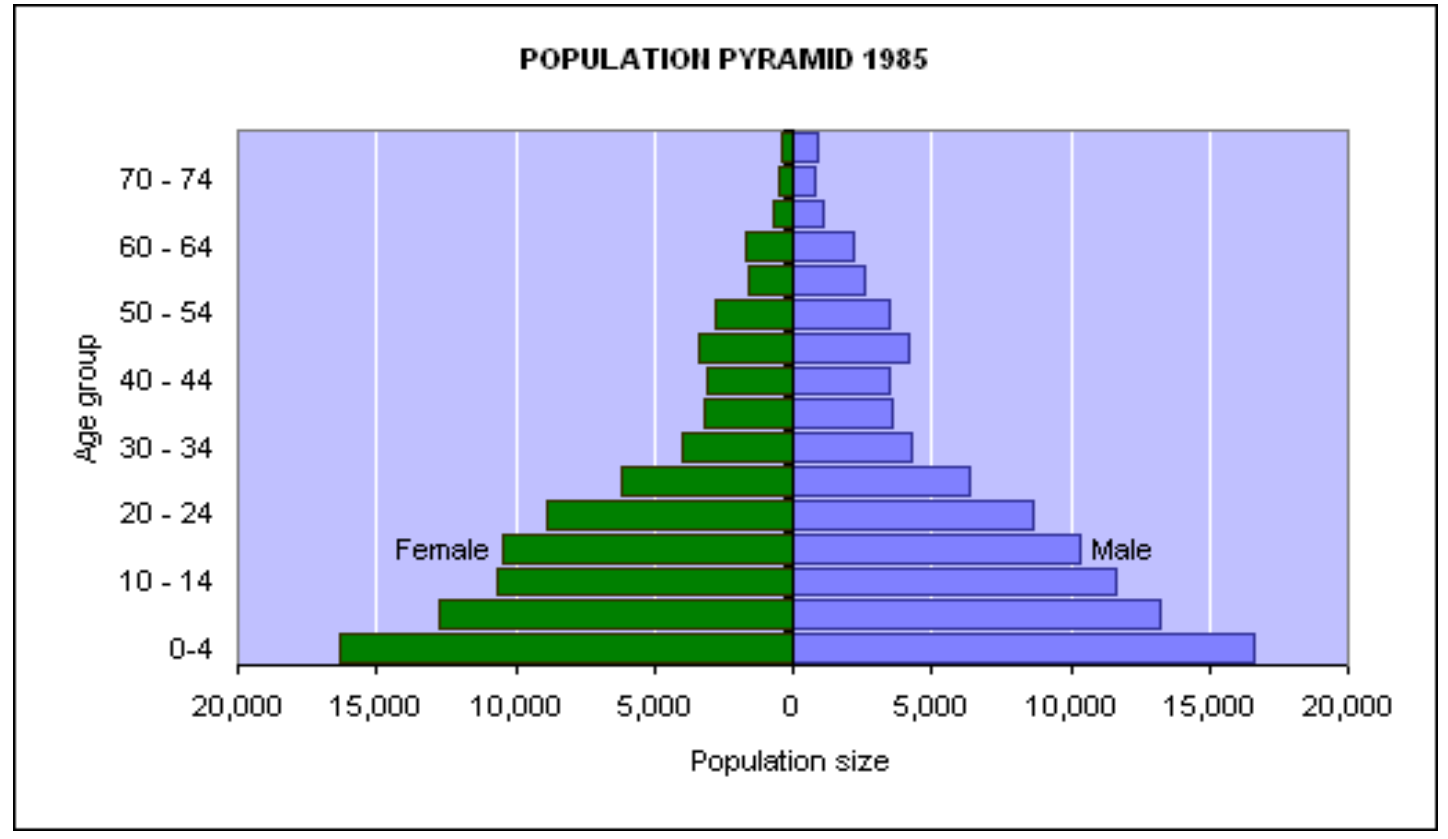

Source: MPND (2005a)

Figure 4.4: Population pyramid 2006

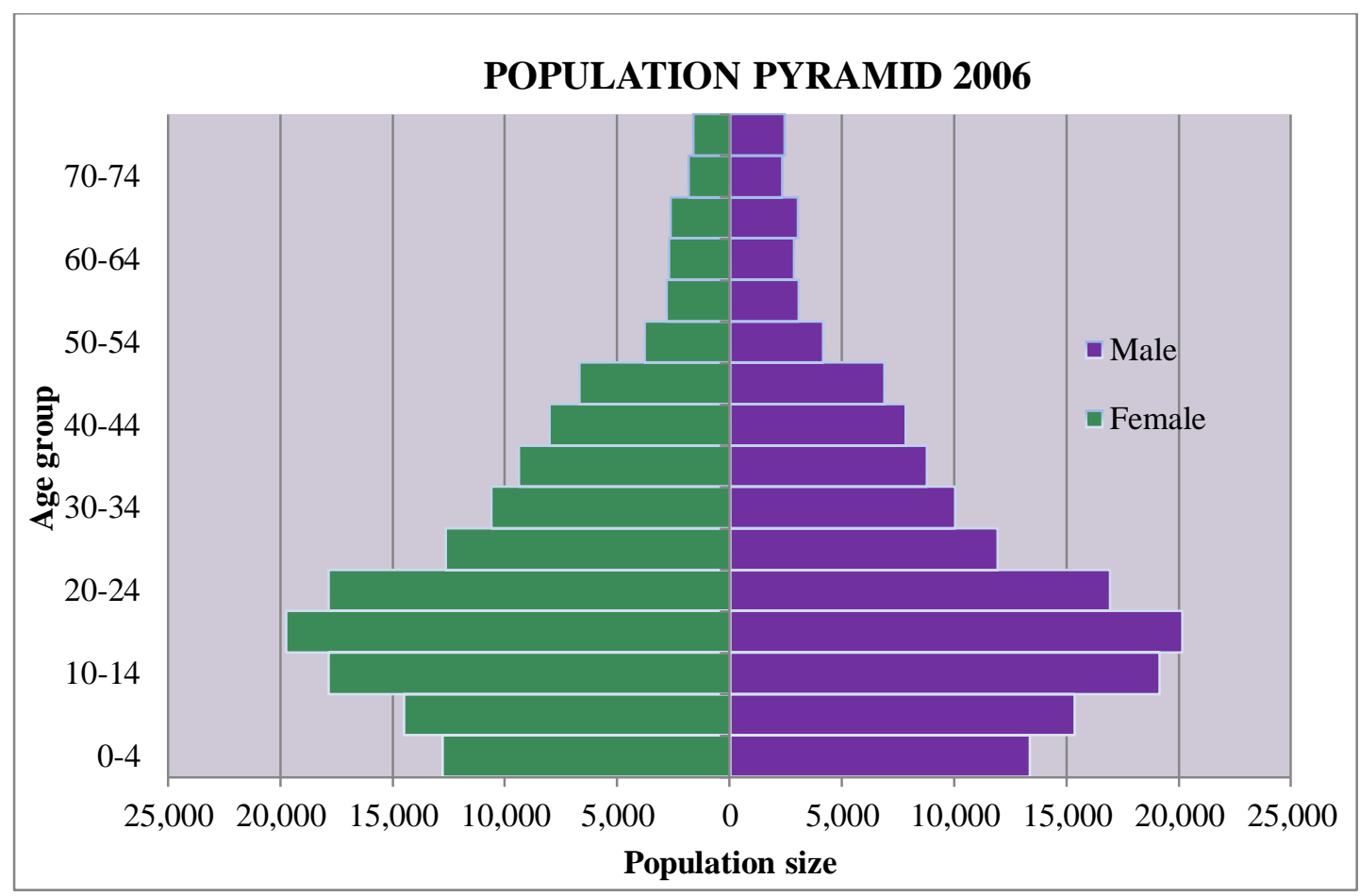

Source: MPND (2008a)

The propelling effect caused by an increasingly educated population combined with a youth population eager for change, was one of the major forces for democratic 
reform in the Maldives, one which political elites and others who might seek to delay or stall the political changes were unable to resist.

\subsubsection{Globalisation.}

In addition to the socio-economic advances reported above, globalising forces, including mass media and travel, had their impact on domestic aspirations for democratisation. From the middle of twentieth century, Maldivians were increasingly being employed as crew in international shipping. As those seamen returned home, they started raising questions regarding the lack of political reforms in the Maldives (Interviewee FO9). The introduction of satellite TV and the internet in the 1990s, followed by affordable cable TV, was an important source of inspiration for the mass movements that were to follow in the drive towards democratic reforms. The "communicational revolution", as termed by a respondent (Interviewee FO4), portrayed the image that the model of government that existed in the Maldives was not practicable anymore, especially after people witnessed the waves of democratic changes sweeping the globe. The once isolated locals who had limited opportunities to travel abroad started to get opportunities to venture to other parts of the world through the international travel routes supporting the tourism sector (refer to table 4.6 for the international aircraft movements in the Male' International Airport). Increases in travelling by Maldivians to all corners of the world were used as a learning experience to aspire to more. The Orange Revolution in Ukraine and the "Change" campaign of Obama gave increased confidence to the locals that they could replicate such changes in the Maldives (Interviewee FO6). The information revolution created a growing awareness among the masses as to how governments functioned in democratic societies. The Maldives became open to global trends, the effects of which are also considered significant in the country's march towards democratic reform. 
Table 4.6: International aircraft movement at Male' International Airport (19852005)

\begin{tabular}{|c|c|c|c|c|c|}
\hline & 1985 & $1990^{\mathbf{6 1}}$ & 1995 & 2000 & 2005 \\
\hline Scheduled & 2367 & 1102 & 5825 & 5973 & 7400 \\
\hline Chartered & 340 & 412 & 836 & 1200 & 742 \\
\hline Non-Scheduled & 320 & 136 & 394 & 517 & 983 \\
\hline TOTAL & $\mathbf{3 0 2 7}$ & $\mathbf{1 6 5 0}$ & $\mathbf{7 0 5 5}$ & $\mathbf{7 6 9 0}$ & $\mathbf{9 1 2 5}$ \\
\hline
\end{tabular}

Source: MPND (2005a, 2006)

\subsubsection{Media.}

Freedom of the media has been a constitutional right for many decades in the Maldives. However, Maldivian governments always found ways to impede the media, at times even revoking licenses and jailing journalists. Over the years several newspapers and magazines that were critical of the government were banned and accused of destabilising the country. On the path to radical political change after the troubles of 2003 and 2004, the media started to open up as never before. After a group of young and educated cabinet ministers was appointed to the Gayoom administration in July 2005, there was significant liberalisation in the media arena. That month procedures for registering newspapers were relaxed and all pending applications were approved in just one day (Mendel, 2009). In June 2007, the state monopoly over broadcasting finally came to an end when licenses were handed to private broadcasters (Mendel, 2009). Soon a private TV channel and several radio channels started operation and since then such stations has multiplied.

In the following years, a number of laws were enacted to regulate media and broadcasting, and to protect freedom of expression ${ }^{62}$ (Ministry of Information and Arts [MIA], 2007). By end of 2006, parliament received six media-related bills: Right to Freedom of Information, Freedom of Press, Maldives Media Council,

\footnotetext{
${ }^{61}$ The drop in 1990 was due to global recession and the Gulf War.

${ }^{62}$ Measures introduced by the government include instituting confidence building measures, introducing private media, creation of the legal framework, and imparting of necessary training (MIA, 2007, p. 3).
} 
Broadcasting, Registration of Publications, and Cable TV Services in the Maldives. After a number of amendments these bills became law and are in force. ${ }^{63}$

The years from 2005 onward were a period of increasing media freedom. Generally freedom of expression, right to information, editorial independence, and journalists' right to protect their sources are respected ${ }^{64}$ in practice (Mendel, 2009). There is no attempt by the state to block or filter internet content (Mendel, 2009). As a result, websites have often been used as a source of information. Such a forum presented an almost unlimited opportunity for flexible, self-determined interaction, in the absence of traditional boundaries of social class and physical space (Meyer, 2002, p. 119). According to an interviewee, it was like the opening up of a shell in which the nation had been enclosed for many years (Interviewee FO6).

It is evident the media has acted as a driving force in bringing about recent regime changes in a number of countries (Voltmer \& Rawnsley, 2009). The media is having a strong impact on the changes in the political landscape of the Maldives as well. Political parties use all forms of media, including social media in order to get their message to the public. This was particularly evident in the run up to the presidential election of 2008. Consequently the Maldivian case also reveals what Meyer (2002) labelled as "media democracies"; democracies (including nascent ones) where political processes are mediated and shaped by the way media portray political incidents and how they are viewed by the general public (Voltmer \& Rawnsley, 2009). Despite the developments in terms of press freedom and a regulatory framework, however, a number of more recent challenges still remain in institutionalising an independent media in the Maldives. Some of these obstacles are discussed later in this chapter (section 4.5.2).

\footnotetext{
${ }^{63}$ They are: Maldives Media Council Law; Maldives Broadcasting Corporation Law; Broadcasting Law; Right to Information Regulation; Cable Television Service Regulation; and Regulation on Registration of Dailies and Magazines.

${ }^{64}$ Some exceptions to this are listed in section 4.5 .2 of this chapter.
} 


\subsubsection{International community.}

After gaining independence in 1965, the Maldives had approached the United Nations for development assistance (Coelho, 1997). The non-aligned status of the nation meant that foreign aid was also received from various countries as well as donor agencies, including neighbouring countries and Arab countries in particular. In fact, the major thrust of Maldivian foreign policy was based on the acquisition of aid for development purposes (Phadnis, 1980). Up until the 1990s, Official Development Assistance (ODA) was a relatively important source of capital for development as the Maldives sought to strengthen its weak economic base. However, this reliance has declined in the last few decades (table 4.7 shows the net ODA received by smallisland states as percentage to their Gross National Income (GNI) for the period 1992 2008).

Table 4.7: Net official development assistance received by small-island states as percentage of GNI

\begin{tabular}{|l|c|c|c|c|c|}
\hline & $\mathbf{1 9 9 2}$ & $\mathbf{1 9 9 6}$ & $\mathbf{2 0 0 0}$ & $\mathbf{2 0 0 4}$ & $\mathbf{2 0 0 8}$ \\
\hline Antigua and Barbuda & 1.19 & 0.78 & 1.29 & 0.19 & 0.66 \\
\hline Bahamas & 0.09 & $\mathrm{n} / \mathrm{a}$ & $\mathrm{n} / \mathrm{a}$ & $\mathrm{n} / \mathrm{a}$ & $\mathrm{n} / \mathrm{a}$ \\
\hline Bahrain & 1.38 & 1.34 & 0.63 & 0.54 & $\mathrm{n} / \mathrm{a}$ \\
\hline Barbados & 0 & 0.22 & 0.01 & 1.06 & 0.22 \\
\hline Cape Verde & 29.49 & 23.51 & 18.02 & 15.77 & 14.75 \\
\hline Comoros & 17.73 & 16.77 & 9.25 & 7.27 & 7.02 \\
\hline Cyprus & 0.37 & 0.25 & $\mathrm{n} / \mathrm{a}$ & $\mathrm{n} / \mathrm{a}$ & $\mathrm{n} / \mathrm{a}$ \\
\hline Dominica & 6.89 & 19.81 & 5.25 & 8.67 & 4.98 \\
\hline Federated States of Micronesia & $\mathrm{n} / \mathrm{a}$ & 49.08 & 42.32 & 34.92 & 34.14 \\
\hline Fiji & 4.28 & 2.23 & 1.7 & 2.4 & 1.29 \\
\hline Grenada & 5.3 & 4.24 & 3.4 & 2.96 & 4.24 \\
\hline Iceland & - & - & - & - & - \\
\hline Kiribati & 34.33 & 13.79 & 16.24 & 10.78 & 13.68 \\
\hline Maldives & $\mathbf{1 4 . 4 7}$ & $\mathbf{7 . 4 9}$ & $\mathbf{3 . 2 2}$ & $\mathbf{2 . 8}$ & $\mathbf{3 . 1 8}$ \\
\hline Malta & 0.15 & 1.96 & 0.56 & $\mathrm{n} / \mathrm{a}$ & $\mathrm{n} / \mathrm{a}$ \\
\hline Marshall Islands & $\mathrm{n} / \mathrm{a}$ & 53.93 & 38.88 & 30.46 & 27.19 \\
\hline Mauritius & 1.39 & 0.44 & 0.44 & 0.52 & 1.12 \\
\hline Nauru & $\mathrm{n} / \mathrm{a}$ & $\mathrm{n} / \mathrm{a}$ & $\mathrm{n} / \mathrm{a}$ & $\mathrm{n} / \mathrm{a}$ & $\mathrm{n} / \mathrm{a}$ \\
\hline Palau & 0.01 & 56.27 & 31.21 & 14.01 & 31.19 \\
\hline Saint Kitts and Nevis & 4.7 & 3.04 & 1.11 & 0.01 & 6.99 \\
\hline Saint Lucia & 6.06 & 7.27 & 1.62 & -2.8 & 1.81 \\
\hline Saint Vincent and the & 8.02 & 9.71 & 1.63 & 2.15 & 3.95 \\
\hline Grenadines & & & & \\
\hline
\end{tabular}




\begin{tabular}{|l|c|c|c|c|c|} 
Samoa & 29.79 & 14.44 & 11.05 & 8.41 & 7.47 \\
\hline São Tomé and Príncipe & $\mathrm{n} / \mathrm{a}$ & $\mathrm{n} / \mathrm{a}$ & $\mathrm{n} / \mathrm{a}$ & $\mathrm{n} / \mathrm{a}$ & 27.07 \\
\hline Seychelles & 4.5 & 3.87 & 3.1 & 1.56 & 1.5 \\
\hline Solomon Islands & 17.62 & 12.59 & 15.67 & 32.03 & 40.69 \\
\hline Tonga & 13.33 & 10.8 & 5.35 & 3.17 & 11.75 \\
\hline Trinidad and Tobago & 0.15 & 0.31 & -0.02 & -0.01 & 0.04 \\
\hline Tuvalu & $\mathrm{n} / \mathrm{a}$ & $\mathrm{n} / \mathrm{a}$ & $\mathrm{n} / \mathrm{a}$ & 21.61 & 32.37 \\
\hline Vanuatu & 22.82 & 14.06 & 17.68 & 11.23 & 15.71 \\
\hline
\end{tabular}

Until January 1, 2011, the Maldives remained among the Least Developed Countries (LDCs) listed by the United Nations. Retaining this LDC status enabled developmental assistance from donor agencies and nations through grants and loans. Grants for development projects in the Maldives outlined in table 4.8 are considered a portion of the total aid received during the period 2002-2008, as several donor agencies provided assistance directly to the population. Despite graduating into the developing countries category, the Maldives continues to receive substantial amounts of ODA from developed countries (Bonofer, 2010, p. 442).

Table 4.8: International grants for development projects for the Maldives (20022008)

\begin{tabular}{|c|c|c|}
\hline Year & $\begin{array}{c}\text { Grant }^{66} \text { for development } \\
\text { projects (In million MVR) }\end{array}$ & \% of total government revenue \\
\hline 2002 & 72.4 & 2.16 \\
\hline 2003 & 72.4 & 1.86 \\
\hline 2004 & 14.1 & 0.33 \\
\hline $2005^{67}$ & 766.4 & 14.65 \\
\hline 2006 & 793.2 & 11.18 \\
\hline 2007 & 935.9 & 10.72 \\
\hline 2008 & 461.4 & 5.24 \\
\hline
\end{tabular}

Source: DNP (2010); MPND (2004, 2005c, 2006, 2007b, 2008b)

\footnotetext{
${ }^{65}$ Net ODA consists of disbursement of loans made on concessional terms (net of repayments of principal) and grants by official agencies of the members of the Development Assistance Committee (DAC), by multilateral institutions, and by non-DAC countries to promote economic development and welfare in countries and territories in the DAC list of ODA recipients. It includes loans with a grant element of at least 25 percent (calculated at a rate of discount of 10 percent).

${ }^{66}$ Includes grants in-kind but excludes direct expenditure by donors.

${ }^{67}$ The rise from 2005 onward was attributed to the Tsunami assistance. However, total grants were on the decline from 2008 as Tsunami-related projects started to wind down.
} 
Some of the donor assistance had targeted governance reform for many years. They include projects funded by the WB and Asian Development Bank (ADB). Though conditionality of assistance had not been directly linked with political reform, such assistance had laid the groundwork for capacity building and institutional strengthening that eventually contributed to democratic reform. When democratic reform was initiated in 2004, the Commonwealth and the United Nations Development Programme (UNDP) also funded a number of projects directed towards democratic reform. From the early stages UNDP was the main international partner providing technical/policy advice and capacity building initiatives, which included assistance during the formulation of the constitution and assistance to several independent bodies including the CSC (UNDP, n.d.). In addition, the Commonwealth sent the former Deputy Prime Minister of Malaysia, Tan Sri Musa Bin Hitam, as a special envoy to provide support for constitutional and electoral reforms during the early stages (Commonwealth Secretariat, 2006, p. 67).

From the late 1990s, opposition activists based abroad had been lobbying for democratic reforms in the Maldives. Developments in mass media and the growing number of dissidents abroad led to a greater effectiveness in attracting the attention of foreign governments. With the diplomatic contact that the Maldives had with most countries of the world, it was impractical to ignore the "requests" of foreign diplomats to adopt a "rights-based approach" and transform the Maldives into a modern democracy (Interviewee FO5). Although foreign aid had been on the decline, it was still considered important for development, and the government was keen to maintain the aid flow. With the political developments of 2003 and 2004, the Maldives was eventually accepting aid that was directly linked to improvements in the political governance of the nation. Though foreign pressure or assistance did not directly lead to democratic reform, persistent pressure from foreign governments such as India (Bonofer, 2010, p. 446) and donor agencies edged the nation towards reform and helped guide the Maldives through the transition.

\subsection{Maldives - an emerging democracy}

Sustaining and consolidating the democratic reforms is vital for democracy to mature in the Maldives. While reversion to the autocratic rule of the past is unlikely and 
there are significant constraints on the powers of the political executive, the road to maturity appears to be an uphill struggle. This section examines the main challenges that the Maldives are facing in relation to sustaining and consolidating democratic transition. The analysis so far reveals that presently the state of democracy in the Maldives is frail and unconsolidated (discussed in Chapter Two, section 2.2.3). This preliminary conclusion is reached by analysing institutional weaknesses, challenges to free media, speed of reform, and implications of island politics, discussed below.

\subsubsection{Institutional weaknesses.}

\section{Lack of horizontal accountability.}

Establishment of numerous statutory bodies independent of the political executive is a new phenomenon in the Maldivian state sector. With democratic reforms, the powers of the political executive have been constrained through the creation of several overseeing bodies, indicated earlier (refer to table 4.3). The relations between the political executive and such bodies have at times been controversial during this initial period and reminiscent of times when the political executive applied its control to all sectors of the state, at times in violation of the constitution or laws. In other words, the "rule of law" was not enforced at times. The integrity of statutory bodies has, thus, arguably been compromised on occasions. A number of such instances where questions have been raised regarding the integrity and independence of such bodies are presented below.

1. Government versus Anti-Corruption Commission: President Nasheed refused to appoint a member to the anti-corruption commission after approval by the parliament. The member was ultimately appointed after 15 months when the civil court ordered the president to do so.

2. Government versus CSC: A number of disagreements between the government and the CSC regarding the interpretation of the CS Act have surfaced. As a result, the commission has taken the government to court several times, even though the government ignored such court rulings in the past (refer to sections 7.2 and 7.3). 
3. Government versus Parliament: During Nasheed's administration, the opposition controlled parliament passed motions and bills limiting or removing specific powers of the executive. A case in point is the changes brought to the CS Act where the appointment of the commissioners was changed from the president's initiation to become the parliament's prerogative. ${ }^{68}$ In retaliation the president challenged the constitutionally granted powers of the legislature by refusing to ratify some of the bills passed by the parliament, at times even when those bills were passed with an absolute majority that would overrule a presidential veto. Another crisis between the president and the parliament erupted when the entire cabinet of ministers resigned en masse accusing the parliament of blocking the government's proposals. According to the PO, the resignations were in protest at the performance of opposition MPs, whom the ministers accused of "hijacking the powers of the executive and making it impossible for the cabinet ministers to discharge their constitutional duties and deliver the government's election manifesto" (PO, 2010a). The move came just before a motion of "no confidence" in the Minister of Education was tabled. After international intervention from neighbouring countries, the entire cabinet was re-instated after a few days. A constitutional crisis once again followed as the government refused $^{69}$ to get consent from the parliament on the ministers' reinstatement as required by the constitution. The deadlock continued until the Supreme Court ultimately ruled on December 2010 that individual ministers should get the consent of parliament to complete the appointment process. Judicialisation of Maldivian politics was becoming common.

4. Government versus Judiciary: The two year interim period of the constitution ended on August 7, 2010. As the parliament failed to appoint a permanent Supreme Court by the deadline, President Nasheed declared the interim Supreme Court invalid. Security forces locked down the Supreme Court and the JSC. Furthermore, the president appointed an "Interim Administrative Body" (PO, 2010c) to oversee the administrative functions of the Supreme Court during that period. The crisis ended when the opposition compromised with the

\footnotetext{
${ }^{68}$ The appointment procedure of the commissioners and the changes to the law in this respect is discussed in Chapter Six (sections 6.4.3 and 6.8.11) and Seven (section 7.4.3) respectively.

${ }^{69}$ In a radio address, President Nasheed said "members appointed to the cabinet would remain in office whether the Majlis approved or disapproved a member”. (PO, 2010b)
} 
government to appoint the permanent Supreme Court. Yet another crisis unfolded when the chief judge of the Criminal Court was taken into military custody on January 16, 2012 - an act that led to daily opposition protests and the eventual resignation of President Nasheed. Immediately after the judge was taken into custody, the prosecutor general and the Human Rights Commission of the Maldives called for his release. The High Court and the Supreme Court also ordered the immediate release of the judge. Government refused to obey several court orders that followed. The judge was released after President Nasheed's resignation on February 7, 2012.

\section{Unstable party system.}

Although political parties may not be a necessity for democracy to flourish (Ankar \& Anckar, 2000), most democracies have multi-party systems. In polities with a high degree of competition for executive office, political parties usually play an important role. More specifically, political parties can make an important contribution during the later stages of the transition after authoritarian rule has been replaced (Randall \& Svåsand, 2002).

With their new found freedom, a big majority of the voting population in the Maldives joined political parties (see table 4.9). By the end of 2009, 13 political parties (Elections Commission, 2010) were registered.

Political parties continue to lead the democratisation process in the Maldives. However, as political parties are a recent introduction to the polity, a conducive environment for parties to operate harmoniously is yet to be found. Firstly, the primary aim of all political parties has been to increase party membership, as the level of funding received from the state budget depends on it. Little or no attention is given by most parties to strengthening the level of internal democracy within the parties. Even when elections are held within parties, it is common for losers in those elections to leave and join a rival party. 
Table 4.9: Membership of political parties

\begin{tabular}{|l|c|c|c|}
\hline & End of 2007 & End of 2008 & End of 2009 \\
\hline MDP & 19,420 & 19,392 & 29,476 \\
\hline DRP & 32,141 & 30,851 & 30,132 \\
\hline AP & 6331 & 6066 & 6078 \\
\hline SDP & 7743 & 6481 & 5445 \\
\hline SLP & 4604 & 3630 & 2944 \\
\hline PP & 1617 & 1149 & 988 \\
\hline MNC & 3894 & 2790 & 2403 \\
\hline PA & 3357 & 2639 & 2340 \\
\hline JP & - & 3307 & 3173 \\
\hline MLP & - & 8134 & 7779 \\
\hline GI & - & - & 2023 \\
\hline DQP & - & 2639 & 3726 \\
\hline PEP & 79,107 & 90,116 & 100,040 \\
\hline TOTAL & - & 3038 & - \\
\hline Source: Elctins & - & - & 3533 \\
\hline
\end{tabular}

Source: Elections Commission (2008b, 2009a, 2010)

Secondly, a large number of individuals join a governing party. In this regard, after the election victory in the 2008 presidential election, the membership of MDP rose to over 45,000 by April 2011 (F. Ahmed, 2011). In contrast, the main opposition party, the DRP, split into two parties after factional conflict. Smaller parties are relatively insignificant because they are without a power base at the grass roots level. Thirdly, parties are more likely to be held together by personal loyalty to a leader than by ideology or class. This is a shortcoming in the efforts made to try and strengthen the parties.

Fourthly, "party hopping" among senior officials also appears to be a significant challenge because it has a wider relevance towards maintaining political stability. Though an opposition coalition claimed a majority in the 2009 parliamentary election, that majority was reversed in favour of the ruling MDP by May 2011 (refer to table 4.10). Several opposition and independent MPs "hopped" on to the ruling party. A report by Transparency International (2011) revealed that the Maldivian 
parliament was perceived by the public to be the most corrupt public institution in the Maldives.

Table 4.10: Parliament composition

\begin{tabular}{|c|c|c|}
\hline & March 2009 & May 2011 \\
\hline MDP & 26 & 34 \\
\hline DRP / PA $^{70}$ & 35 & 31 \\
\hline JP & 1 & 3 \\
\hline DQP & 2 & 1 \\
\hline Independent & 13 & 8 \\
\hline
\end{tabular}

Source: Elections Commission (2009b); A. A. Saeed (2011)

Although political parties have been an important introduction to the highly contested Maldivian polity, the omnipresence of parties in the daily life of society has ensured a politically-charged environment that has at times been blamed for its polarisation. In this regard, islands and families divided by split party loyalties are evident throughout the nation (Interviewee FO5) (discussed further in section 4.5.4). Burnell and Gerrits (2010, p. 1073) state that the "political and institutional environment in many new democracies is not particularly conducive to solid and vibrant democratic parties and competitive party systems". The Maldives evidence suggests risks to "solid and vibrant" political parties although the party system seems quite competitive.

\section{Weak civil society sector.}

A vigorous civil society is an important ingredient for sustaining and consolidating democratic values. As Diamond (1993, p. 431) points out, in addition to the importance of political elites and activists:

to ignore the beliefs of the wider society is to fail to appreciate the considerable degree to which influence and pressure for action may flow from the bottom up, constraining elites and perhaps vitiating or undermining even

\footnotetext{
${ }^{70}$ After the splitting of DRP in late 2011, this coalition ceased to exist.
} 
their sincerely democratic inclinations. This is one reason why stable democracy requires mass habituation to democratic values and orientations, and thus why a vigorous civil society is important, alongside a well-articulated party system, to provide arenas in which citizens can practice democracy, internalize its values and limits, and hold elites accountable.

In the absence of any legal impediments to the establishment of CSOs, traditionally the Maldives have had a relatively active civil society, especially at the island level. Such organisations can vary from being generalist to being focused on a specific target group or function. Among them a total of 34 CSOs which make up 5.8\% of all CSOs can be considered to be focused on promoting good governance and democracy (UNDP Maldives, 2011). However, with the arrival of democratic reforms and the impact of politicisation of the public life, the role of the civil society is yet to be determined as CSOs have a relatively little impact on political matters. This may be due to a number of reasons. A government led national conference of CSOs held in August 2010 highlighted the main challenges faced by CSOs. Some of the germane issues are listed below:

a) Lack of a framework for financial assistance from the state and businesses.

b) No government budgetary allocation for CSOs to provide services to the public.

c) Lack of awareness among government officials of the role of civil society.

d) Lack of consultation by the government in setting, planning, and implementing policies.

e) Continuous pressure by politicians on CSOs.

f) Lack of opportunities for civil society to develop because government and state-owned enterprises provide similar services to the public.

g) Lack of opportunities for capacity-building.

h) Lack of office space. (Ministry of Home Affairs, 2010)

Past experiences, especially at the island level, have shown that civil society can be an effective force in moulding a society. Several initiatives by CSOs have arguably "gone cold" due to a combination of the reasons mentioned above. Strengthening of 
civil society is important because it can contribute to consolidating democracy and make "reversal to authoritarian rule more difficult" (Sørensen, 2010, p. 453).

\subsubsection{Challenges to free media.}

Media is undoubtedly an integral part of a modern democracy. The outreach of media in the Maldives has meant that media agencies are the prime source of information for the general public. As Loveless (2008) concluded, citizens in new democracies purposively use the media for obtaining political information. However, even after the Maldives moved into a multi-party electoral democracy, the media has had difficult times (International Federation of Journalists [IFJ], 2011). Some of the main challenges faced by the media during the past few years are:

a) The Maldives Broadcasting Corporation (MBC) Bill was ratified by President Nasheed on April 20, 2010. Under the Act, the MBC was to be the public broadcaster and all assets held at that time by the state-owned media (TV and radio) were to be handed over to the statutory corporation. In accordance with the law, a nine-member board was appointed by the parliament but the government refused to hand over the assets to the corporation. Although the civil court ordered the government on May 12, 2011, to hand over the assets to MBC within 20 days ("Dhaulathuge Media 20 Dhuvahuge," 2011), government maintained its refusal to do so. ${ }^{71}$ The general perception was that the government held on to the state media because it was used as a propaganda arm for the ruling MDP (IFJ, 2011).

b) Maldives Media Council is the statutory authority entrusted with regulating the media. Of the 15 members in the council, seven members are elected from the general public, but to run for office they legally require government endorsement. In the election of May 2010, allegations were made that the seven members of the public who received government endorsement were party loyalists (IFJ, 2011).

c) When covering protests, the police have been accused of using excessive force against journalists and at times arresting them. This was evident in

\footnotetext{
${ }^{71}$ State media was handed over to MBC after President Nasheed's resignation.
} 
October 2010 when journalists were allegedly beaten by batons, some were shackled and some briefly detained during a protest (IFJ, 2011). Two journalists were also detained briefly when covering an opposition protest in late April 2011 (IFJ, 2011) while a number of journalists sustained various injuries while covering those protests that continued for almost a week (Maldives Journalist Association, 2011).

d) The coverage of the parliamentary sittings was also questioned when in December 2010, the General Committee of the parliament summoned journalists from two private TV channels, where they were accused of selectively editing video footage of a parliament member (IFJ, 2011).

e) In February 2011, two journalists were summoned for interrogation by the police after reporting on a pornographic video racket scheme, which involved a number of senior government officials and prominent figures. The journalists were pressed to reveal the source ${ }^{72}$ of their information, which was a clear violation of the constitution.

f) The biggest opposition protest against President Nasheed was held on December 23, 2011. Due to the coverage given by the media, soon after, the Minister of Defence threatened to take action against any media outlet that "do not protect national security" ("Salaamathaa Behey Kanthah,” 2011). In January 2012, government also warned the media that steps would be taken against media operators who "commit the crime of spreading false information" ("Press Secretary Warns," 2012). The Maldives Broadcasting Commission and the Media Council condemned the intimidation of media by the government ("Threatening The Media," 2012).

g) TV channels that broadcast coverage of opposition protests and news were often targeted by the ruling MDP. In one of many such incidents, the parliamentary leader of MDP, Moosa Manik, referred to private TV channels in the Maldives as the fruit of "ill-gotten" wealth and vowed to teach them a lesson during remarks made in 2010 (IFJ, 2011). Protests by the members of the ruling MDP outside private TV stations were also

\footnotetext{
${ }^{72}$ Article 28 of the present constitution states "Everyone has the right to freedom of the press, and other means of communication, including the right to espouse, disseminate and publish news, information, views and ideas. No person shall be compelled to disclose the source of any information that is espoused, disseminated or published by that person."
} 
common when programmes that criticised them were aired. During the opposition protests of January/February 2012, two TV channels were attacked several times with arson at one station on February 6, 2012.

Many new democracies are yet to succeed in transforming their media into fully democratic institutions (Voltmer \& Rawnsley, 2009). Therefore, the experiences of the media in the Maldives, especially the challenges faced, are not unique by any means. At the time of this research, some significant risks remained to media freedom. The expectation is that, as democracy matures, such challenges will be overcome.

\subsubsection{Speed of reform.}

The speed with which the Maldives transformed into a democratic polity is significant, a process that probably only a handful of nations went through in such a short period. Though democratic transition in countries such as the United Kingdom took many decades, "contemporary societies must telescope such a long historical process into a few critical years" (Linz, 1990, p. 143). Some believed that reform came far too quickly for people to digest in the Maldives: "the people were not prepared to adjust themselves to the democracy that was brought in a very sudden manner" (Interviewee FO11). This may be due to lack of adequate time to fathom the reforms as well as inadequate consultation and awareness campaigns regarding democracy.

Apart from the extensive changes made to the constitution, the number of bills passed by the parliament also increased significantly (see table 4.11). Several of the laws passed since 2007 were aimed at establishing statutory bodies that operate relatively independently of the political executive. The Maldivian state sector was new in operating all the independent bodies simultaneously. One interviewee summarised the impact:

As a result of creating too many laws and too many institutions over a short period of time, our unconscious minds have been unable to absorb all this. Still we go along with our experience or do things the way we have been used to, 
then we make decisions based on this. When a problem arises, only we realise that in doing so we have violated the boundaries of another institution. By then so much friction has clogged up relationships between both parties. (Interviewee, GO6, Aminath Nihan Translation)

Table 4.11: Bills submitted and passed in the majlis

\begin{tabular}{|c|c|c|}
\hline Year & Bills submitted & Bills passed \\
\hline 2000 & 4 & 4 \\
\hline 2001 & 7 & 5 \\
\hline 2002 & 3 & 3 \\
\hline 2003 & 8 & 7 \\
\hline 2004 & 8 & 4 \\
\hline 2005 & 17 & 6 \\
\hline 2006 & 30 & 4 \\
\hline 2007 & 17 & 6 \\
\hline 2008 & 25 & 15 \\
\hline 2009 & 60 & 16 \\
\hline 2010 & 29 & 21 \\
\hline
\end{tabular}

Source: Rayyithunge majlis (n.d.)

\subsubsection{Island politics.}

Smallness can pose considerable challenges during the consolidation of a democracy. This has proved to be the case in the Maldives. Although it makes sense for small societies to work together to promote common good, in practice this has proved a difficult task (J. Henderson, 2003, p. 229). Political elites in the Maldives often find ways to resolve differences through negotiation. However, for the society at large, features such as social closeness have not necessarily aided in bridging the political divide. That is because, firstly, a stable multi-party political culture has yet not fully developed in the Maldives. Secondly, the country's political culture cannot yet fully support what Weber refers to as "legal-rational" form of authority. The newly injected democratic ideals are putting a strain on a population that is mostly confined to small islands with a couple of hundred citizens in most cases (see table 
4.1). The loss of social fabric and a growing polarisation among small communities of the Maldives is also evident.

Political parties have been proved to be a particularly divisive factor in some of the island nations of the Pacific (J. Henderson, 2003, p. 230). To some extent, this is also true for the Maldives. The two major parties of the MDP and the DRP often focus on personal politics rather than on issues and this creates deep divisions in society. As an interviewee points out, "Our society after the introduction of political parties is more divided than ever; never in the history of Maldives... this country was this much divided" (Interviewee FO1). Describing the deepness of the divisions within small communities of the islands, one interviewee said, "There are islands where people of the ruling party and the opposition will not inter-marry. They will not trade from shops from each other's party" (Interviewee FO5).

Discrediting someone based solely on false accusations may not be difficult in such small communities. The nature of personal politics often creates long-lasting scars in some island communities, even within families. One interviewee noted that the island communities are increasingly becoming fragmented because all these reforms were, "crammed down people's throats in such a short space of time" (Interviewee FO5), without generating any awareness as to how to live in a multi-party environment. In describing the difficulties for small communities, another responded:

It is difficult to maintain this type of system in such a sparse population. Especially in a place like the Maldives, with blood relations. It's a close-knit community. So the effects are profound. So to sustain this system, we have to put in a lot of effort. We have to spread awareness, create awareness among people. Without this, we would face a lot of problems; the social problems we have would be amplified. (Interviewee GO1, Aminath Nihan Translation)

\subsection{Conclusion}

The Maldives has had a strongly centralised and autocratic system of government for nearly all of its recorded history, but with qualifications. The main qualifications are: 
(1) the need for most rulers to take some account of the interests of a small number of powerful families; (2) some limited formal constraints on the use of the ruler's power from the role of advisers and the majlis; (3) some incidents of rulers being ejected from office as a result of clashes with the powerful elites; (4) an on-going problem of imposing strongly centralised rule over a geographically scattered polity, which permitted local economic and social power bases to develop.

More recently, the advancements in economy, education, mass communication, and globalising influences - particularly due to the return of the Maldivians educated abroad returning with new ideas of governance - have contributed to the rise of selfexpression values, setting the conditions both for the emergence of new elites and for increased mass influence on political development. The polity was ripe, in effect, for the catalysing events of 2003 that began the process of mass responsive democratisation. The process that followed, however, was not a revolution with the violent replacement of old elites by new, but a process of transplacement as defined by Huntington (1991-2), and the elements of democratisation were effectively then negotiated amongst old and new elites. This process of negotiation extended to the construction of a wide range of formal institutions including the new CS Act. The islandness of the nation was also to some extent a factor in the design of the constitutional architecture.

The Maldives is an emerging democracy. Numerous reforms of governance and political system of the island nation were undertaken in just a few years. Since the 2008 presidential election, however, the country has been in almost continuous political turmoil, culminating in the highly disputed resignation of the first democratically elected president in February 2012. Given these events together with the present institutional weaknesses, continuing challenges to the media, and the negative effects of multi-party politics on the small-island communities, with no workable solution in sight, it is safe to assume that consolidation of democracy in the Maldives is still some distance away. Nonetheless, the continuous involvement of the general public in the political environment should help sustain the rise of selfexpression values which in turn lead to efforts to strengthen democratic institutions.

The next chapter focuses on the administrative history of the Maldives and the road which the nation traversed en route to the formation of a statutory CS. 


\section{CHAPTER 5: EN ROUTE TO A STATUTORY CIVIL SERVICE}

\subsection{Introduction}

The Maldivian system of administration has developed in a manner similar to other autocratic systems. The employment framework developed during the 1960s had similarities to other jurisdictions, but with rapid change in the political context, had to confront a new basic problem, which is the appropriate relation between the CS and political executive in an emerging democracy where there were significant constraints on the powers of the political executive.

This chapter presents a brief history of public administration in the Maldives that eventually led to the formulation of a statutory CS. The aim is to show that the Maldives had a system of administration that evolved over the years and when the statutory CS was established, the basic elements of administration were already in place.

In this regard, this chapter argues that the public administration of the Maldives went through three phases en route to a statutory CS: 1) early history to early 1930s, 2) early 1930 s to mid-1970s, and 3) mid-1970s to 2008. The first phase covers the evolution of basic government and institution building. A turning point in the nation's history occurred in early 1930s with the promulgation of the first written constitution of the nation. The last major period from the mid-1970s was the result of the expansion of socio-economic activities that required modernisation of government organisations and services to keep pace with the changing environment. All three phases prior to the CS Act were in the context of an autocratic system of government with no executive competition other than by shift of the power balance within the ruling elite and very few effective constraints on executive power, including over the employment of staff.

\subsection{Early history to early $1930 \mathrm{~s}$}

In a nation where $99 \%$ of its area is ocean, sea travel would have existed since the first settlers arrived. Along with the art of boat-building and the use of the monsoon 
winds, journeys to distant places were common. Historical evidence shows that cowrie shells were used by locals for trade with other countries (Suryanarayan, 1998, p. 121), a tradition which lasted until the latter half of nineteenth century (N. Mohamed, 2008, p. 65). The geographical location of the archipelago also made the Maldives a convenient stop for trading ships on the Arab-China trade route (Chaudhuri, 1985). With increasing knowledge obtained from travelling visitors, the locals ventured to distant countries. Records shows frequent trade visits to areas of Bengal, Burma, Thailand, and Indonesia on the east and Arabia, the Persian Gulf, and East Coast of Africa on the western side (N. Mohamed, 2008, p. 67). Maldivians ventured as far as the court of the Roman Emperor Julian ${ }^{73}$ (Rolfe, 1937) and the Emperor of China $^{74}$ (Pelliot, 1904, cited in Maloney, 1980, pp. 110-111). With advancement in travel, contact with the outside world grew exponentially. Such contacts were bound to bring experiences and practices from more advanced administrations and civilisations to the Maldives.

Despite this evidence of travel by locals to many parts of the world, little is known about the system of administration that existed during that time. Maloney (1980, p. 313) states that in one of the earliest reference to the Maldives, an Arab historian by the name of Al Mas'udi wrote in 916 A.D. that the country was ruled by a queen and the people were subject to one government. N. Mohamed (2008, p. 5) also states that according to the writings of Al-Idrisi ${ }^{75}$ in 1150 A.D., a system of tax collection existed in the Maldives. This means a number of state servants would have been employed for such tasks. State servants would have been employed even for trading with other nations. In early as 500 A.D., the ruler of the nation had control over the export and exchange of cowrie shells in return for commodities not available locally (N. Mohamed, 2008, p. 9). Portuguese travel to the nation in early sixteenth century also confirms the existence of such a system (Bouchon, 1975/1988, pp. 42-3).

\footnotetext{
73 Ammianus Marcellinus (c. 330-400 A.D.), a Greek from Antiokia who fought under Emperor Julianus writes - "On one side, the peoples beyond the Tigris and the Armenians begged for peace. On another, the Indian nations as far as the Divi [Maldives] and the Serendivi [Sri Lanka] vied with one another in sending their leading men with gifts ahead of time" (Rolfe, 1937, p. 213).

${ }^{74}$ According to Pelliot (1904), a Chinese document of the Tang Dynasty, written between 785 and 805 A.D., shows Maldivians visited China in 658 A.D. and 662 A.D.

${ }^{75}$ Taken from an Arabic book titled "Kitab Nuzhat Al Mushtaq Fi Ikhtiraq Al Afaq".
} 
Traveller Ibn Battuta visited the Maldives twice between 1343 and 1346 and confirmed an established system of governance (A. Gray, 1890, p. 435). According to his writings, Sultana Khadija was reigning during that period and she employed a thousand men as an army who were paid monthly by rice (A. Gray, 1890, p. 450). Regarding the composition of the inner circles of the ruling elites, Ibn Battuta writes:

The people of the Maldives call the Grand Vizier [Vazier], the Sultana's Lieutenant, Kalakí; and the Kázi [Qaal'ee], Fandayarkálú [fandiyaaru]. All judgements are in the jurisdiction of the Kázi: he is more highly esteemed by the people than all other men, and his orders are executed as those of the Sultan, and even better. He sits upon a carpet in the audience hall: he possesses three islands, whose revenue he places to his private account, after an ancient custom established by the Sultan Ahmed Shanúráza. The Preacher is called Handíjarí; the Chief of the Treasury, Fámeldári; the Receiver-General of Revenue, Máfákalú; the Minister of Police, Fitnáyak; and the Admiral, Mánáyak. All these have the title of Vizier. (A. Gray, 1890, pp. 450-1)

Sultans and sultanas reigned from the throne appointing nobles as advisers. Such nobles came from the ruling clan, a status that was achieved by being an offspring of that elite group or through marriage ties with the clan (Nasheed, 2003, p. 3). ${ }^{76}$ They were normally based in the capital, Male'. In the outer regions, Kangathi Beykalun (Governors) were responsible for administration. They were nominated by the people in the regions and presented to the sultan, who would appoint and confer the titles (DIB, 1990, p. 10). In addition to the significant power and authority they held, they were also able to control the wealth of the country. In the atolls, Atholhuverin (Atoll Chiefs) appointed by the state were the focal point of the state government. Though Kangathi Beykalun faded out of the power circles with time, Atholhuverin were very senior and powerful up until the end of $2008 .{ }^{77}$ At the island level,

\footnotetext{
${ }^{76}$ Reference is made here to a book authored by President Nasheed. Later in this thesis, reference is made to another person with the exact same name.

${ }^{77}$ Under the reforms of 2008, councils were elected in the cities, atolls, and islands. The first such election was held in February 2011.
} 
Kathee $b u^{78}$, the administrative and judicial officers of the islands had multiple functions of island magistrate, chief revenue collector, and religious head (Phadnis \& Luithui, 1985, p. 11). Their religious functions included delivering Friday sermons as well as enforcing Islamic behavioural ideals (Maloney, 1980, p. 183). Their magisterial functions included conducting of marriages in the islands (Bell, $1883 / 2004$, p. 64). The bottom of the hierarchy was at the ward level, where Muskuli avas was in charge of individual local administration of the wards while Mudhim ${ }^{79}$ were in charge of individual mosques (Phadnis \& Luithui, 1985, pp. 11-2).

As evident from the writings of Ibn Battuta, sultans organised their power structures by devolving judicial and religious functions to the Qaal'ee (Judges) and overall administration and revenue collection of the state to the Vaziers (Ministers) (Phadnis $\&$ Luithui, 1985). The chief justice or the fandiyaaru, did not require any family ties with the ruling clan, but was required to be educated in Islamic principles (Nasheed, 2003, p. 5). ${ }^{80}$ In the absence of written laws, Qaal'ee were expected to uphold the standards of Islamic shari'a (Dunn, 2005, p. 231). Reference to treasury house or bodu badeyrige has also been given in literature (Nasheed, 2003, p. 61) ${ }^{81}$ indicating the centre of state finances. Bodu Badéri or chief treasurer employed accountants and clerks to assist with the duties of revenue (Bell, 1883/2004, p. 66). Other references to senior posts include harbour chief (Young \& Christopher, 1844), army chief, palace auditor, customs collector (Bell, 1921) (cited in Maloney, 1980, p. 199), and port doctor who ensured that the ships docking in the harbour were free of diseases (Bell, 1883/2004, p. 67). This shows that basic organisations have existed for many centuries in the Maldivian state administration. In a sense, little changed over the centuries as far as the overall dynamic of these functions is concerned.

\footnotetext{
${ }^{78}$ According to Maloney (1980, p. 184), katheebu in northern atolls used to be selected by consensus among the islanders, while the position was mostly hereditary in the southern atolls.

${ }^{79}$ Mudhim need to ensure the mosques are decent and in order, call for prayers, and lead the prayers (Bell, 1883/2004, p. 65). At times, the words mudhim and imaam are used interchangeably. These titles and functions remain the same even presently. The majority of the mosques are maintained by the government (some by wealthy individuals) and almost all the imaam are under the government payroll.

${ }^{80}$ Reference is made here to a book authored by President Nasheed.

${ }^{81}$ Reference is made here to a book authored by President Nasheed.
} 
It is widely believed that in none of the instances when the sovereignty of the country was interrupted by foreign occupation (see section 4.3.1), did the occupiers make any impact on changing the local administrative system. As Maloney (1980, p. 129) explains, even when the Maldives was under British protectorate status, "the British never administered the Maldives, so their stamp left so impressively on the rest of South Asia is altogether missing". There was no physical presence of the British in Male' to exert any influence on the internal administration of the nation (DIB, 1990, p. 3). In particular, the Maldives did not inherit or copy a CS as seen in the neighbouring countries. Salleh and Othman (1992, p. 74) stated that in the Maldives:

a number of institutions and practices which formed an important part of the administrative system in many other developing countries were found lacking. The system that evolved was an outgrowth of long heritage and culture and was essentially traditional in outlook.

This does not imply there is no influence on the Maldivian system from systems in other countries. In the past, the Maldives has invited foreigners to hold high posts and this would have some impact on the administrative practices. In this regard, foreign sultans who held the Maldivian throne included the Arabs Sayyid Muhammad (1466-68) and Sarif Muhammad (1510-13) (Maloney, 1980, pp. 192-3). Furthermore, the post of Qaal'ee was at times filled by foreigners. Ibn Battuta, the Muslim traveller mentioned previously, was appointed to the post of Qaal'ee during his stay in the Maldives (A. Gray, 1890, p. 459). But the basic design of the national administrative system as it developed under the sultans were nevertheless a more or less unique local product that evolved mostly out of tradition and cultural practices (Latheef, 1993).

By the start of the twentieth century, the sultanate was evolving to a figure-head position, with the prime minister acting as the head of government. Systems of taxation, national defence, justice, and administration were established through the practices and conventions that have evolved over the centuries (DIB, 1985, p. 18). A major shift in governance was on the horizon with the introduction of the first 
constitution in 1932 which would change the system where the rulers were advised on the matters of the state by advisers and councils (N. Mohamed, 2008, p. 31).

\subsection{From early 1930s to mid-1970s}

The change of government into a constitutional monarchy marks a turning point for public administration and the system of governance. With the first written constitution of 1932, the functions of the state were codified in law. Growing recognition was given to state officials as the services provided to the public expanded. The prime minister and the council of ministers were given legal recognition by the constitution (Phadnis \& Luithui, 1985). Sir Bernard Henry Bourdillion, K.C.M.G., Chief Secretary of Ceylon (Sri Lanka), provided advice to the Maldivian government on formulating the constitution (DIB, 1990, p. 3), indicating the possible foreign influences that would have been included. Primarily, Arabic names were used to denote the portfolios during those times. Along with the political changes in the next decades, the portfolios and functions of the ministries kept changing, most of which then took English names. Conversion to a republic in 1953 did not change the status of state officials. Furthermore, as Zameer (1994) states, in the absence of a distinct local administration, all government officials throughout the nation were considered direct officials of the central government. However, it is believed that basic rules of employment were written and used during these stages. These rules further developed over the years.

The two decades following the mid-1930s were a period of hardship and suffering for the Maldives. The effects of the Second World War were felt hard and it took several more years to recover from the aftermath. The daily focus on basic survival prevented attention towards any significant administrative reform during this period. As a result there were no major shifts in administrative practices. However, towards 1958, with increases in development, the government started to undergo a period of relative modernisation (Zameer, 1994; Interviewee GO4).

The first attempt to provide legal status for government officials in the Maldives was in 1968 by Law 1/68J (Official Kanthah [Issues] Chapter 1). Article 3 of the law stated, "The President has the authority to appoint, dismiss and transfer personnel for 
state duties". Such broad powers given to the chief executive meant that he was able to manoeuvre the entire public service as he saw fit.

Once again, the need to reform governance started to appear. This time there were two main drivers. Firstly, as a result of growth in the educated population, there was an inflow of better educated people into the government employment, and they brought ideas and incentives for administrative change. Secondly, economic development required a better public service to regulate and guide growth. This was led by the introduction of tourism in the early 1970s that required expansion of infrastructure to accommodate the influx of tourists.

\subsection{From mid-1970s to 2008}

\subsubsection{Impact of education and training.}

As mentioned in the previous chapter (see section 4.4.6), significant developments in the education sector since the mid-twentieth century have had a profound impact on the democratisation process in the Maldives. Similarly, individuals who pursued their education and returned to work in the public sector have had a significant impact on the administration of government. Throughout the twentieth century, several future leaders gained their education in Sri Lanka which had a Westminstertype administration (Interviewee GO4). Others studied in the Arab nations, particularly in Egypt, and dominated the political spectrum of the nation from the 1970s. As the years went by, more and more educated professionals returned from all corners of the globe to work in the public sector (see section 4.4.6). It is likely that what they learned while abroad would have had an impact on the public administration and the governance of the nation. However, rather than borrowing patterns of administration in a wholesale manner, changes started to appear piecemeal with a more Maldivianised outlook.

The opportunities for public officials at all levels to obtain professional training from overseas were also significant. According to an experienced former senior government official, delays in administration started to appear at the Ministry of Foreign Affairs once a few officials returned after receiving training from the Indian 
Foreign Service (Interviewee FO9). In other words, bureaucratic practices of the Indian Foreign Service started to have an impact on how administration was organised in the Maldives. For example, among numerous such reforms borrowed from other countries, the performance appraisal system formulated in 2001 had a significant influence from Malaysia (Faizal, 2005).

\subsubsection{International assistance.}

In September 1979, an international mission to examine the state of the CS in the Maldives was undertaken by the United Nations Economic and Social Commission for Asia and the Pacific (ESCAP). Two of the main objectives of that mission were:

a) To undertake an overall appraisal of the administrative system with a view to identifying specific steps for facilitating the restructuring of the government machinery on a planned basis;

b) To recommend measures for rationalising and reorienting the civil service. (Banerjee, 1979, p. 1)

This assessment was considered to be a launching pad for future reforms in an environment where systematic focus on administrative reform had been absent, resulting in the creation of an administrative culture that had given rise to high levels of centralisation. The centralised system was often maintained by appointing close relatives and friends of the president to important positions of the government (Suryanarayan, 1998, p. 117). To counter such practices, the most pertinent areas for public administration development were identified by the ESCAP mission as:

a) To delegate authority and strengthen accountability among all levels of government;

b) To delegate financial and organisational transactions at the central government level;

c) To establish an integrated management system at the apex of government;

d) To develop strategic objectives for government ministries and departments;

e) To establish a National Personnel Management and Administrative Reform Agency; 
f) To align the performance of government employees with national development goals. (Banerjee, 1979)

In addition to these proposals, one of the significant recommendations made by the mission was to provide a legal basis for the CS. The report suggested the inclusion of broad principles of the CS in the amended constitution and the formulation of a CS Act (Banerjee, 1979). Although most of the report's recommendations were not adequately implemented, ${ }^{82}$ over the next decades several donor aid projects ${ }^{83}$ aimed at reforming the administrative machinery of the government were undertaken which contributed to establishing a statutory CS.

\subsubsection{Organisational development.}

The structure of the Maldives state in 1980 is shown in figure 5.1 and annex 5 gives a government organisation chart at the end of July 1979. By 1979 it was evident that strategic reform of this government machinery was a necessity because the prevailing structures were relatively basic and narrowly conceived. According to Banerjee (1979, p. 12), "several broad functions of government which are organically intertwined in their subject matter are split into separate agencies; and there are admixtures of other functions which violate principles of commonality and managerial cohesiveness". As a result, one of the first major organisational changes implemented by the newly elected government of 1978 was to establish a National Planning Agency designed to coordinate the entire national planning function of the government.

Under the reign of President Gayoom, there were several rationalisations of government ministries and departments. More importantly, there was a huge leap in the number of public sector organisations: ministries, departments, parastatals, and other offices grew from 32 in 1958 to 116 in 1991 (Zameer, 1994). To handle this growth, there was an increasing need to strengthen the internal administration of those organisations. In this regard, the opening of the Maldives Centre for

\footnotetext{
${ }^{82}$ Refer to section 5.4 .8 for some success stories.

${ }^{83}$ Also discussed in section 5.4.8
} 
Management and Administration (MCMA) in October 1991 was a milestone in developing a professional CS. The centre was established to provide professional need-based, highly practical training and development programmes for senior, middle, and supervisory level managers in the CS (Zameer, 1994). The centre was expected to play an important role in the development of skills amongst the civil servants and in the overall socio-economic development of the nation. Over the years MCMA evolved more towards academic training rather than professional training and eventually became part of the Maldives College of Higher Education (MCHE), which in turn became a university.

Figure 5.1: Administrative setup of the Maldives (1980)

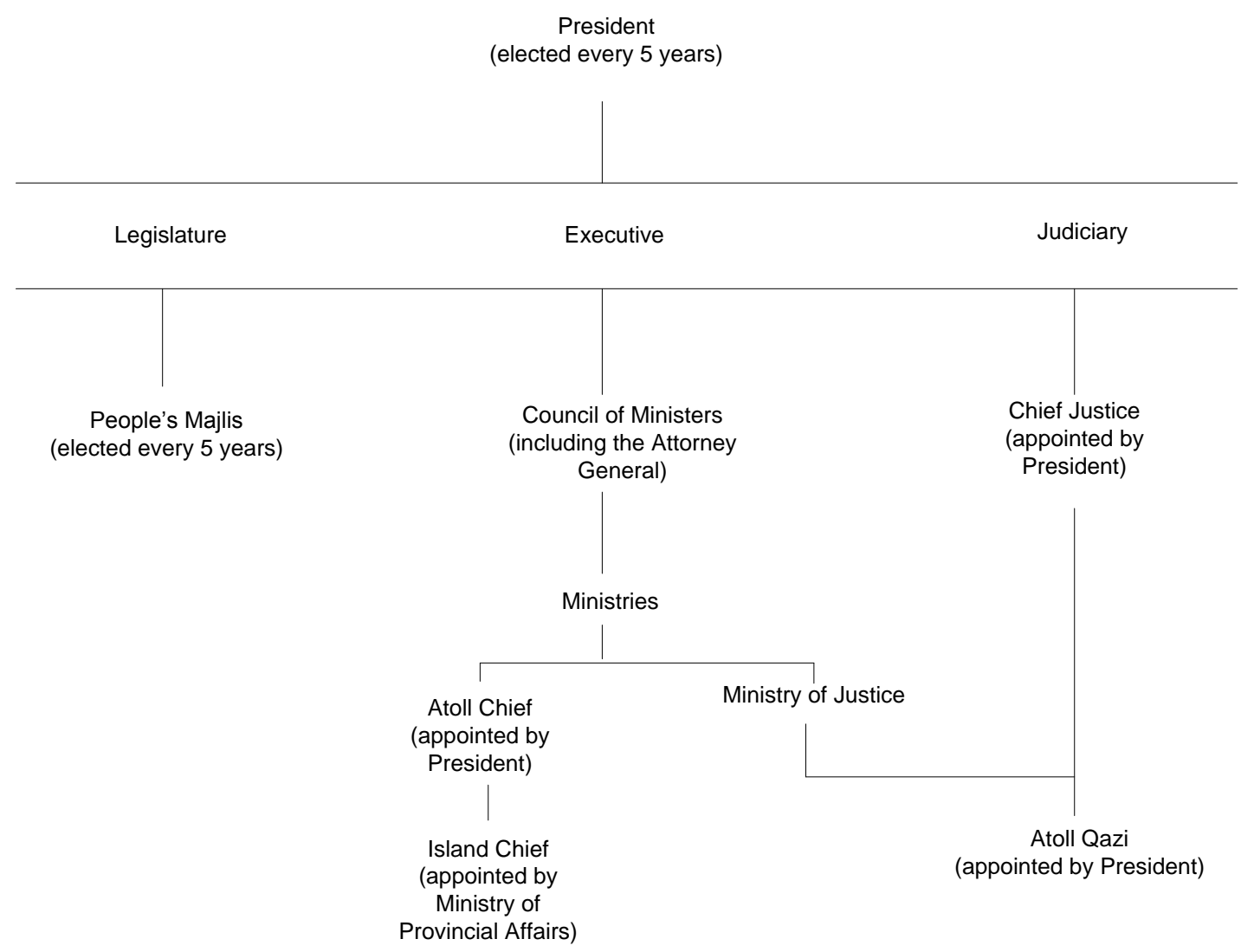

Note: Modified based on the diagram by Phadnis and Luithui (1985, p. 106)

Oversight bodies were also established to help ensure political and administrative accountability in a government of growing size and complexity. For instance, since the establishment of an Audit Office in 1949 (ADB, 1997), the organisation has evolved into a statutory body that operates under modern auditing standards. Similarly, the government established an Anti-Corruption Commission. 


\subsubsection{Centralisation of administration.}

With the geographical dispersion of the archipelago, one might assume there would be a strong emphasis on decentralisation in the governance of the nation. Historically, this was sometimes the reality, but developments in mass communication and transport facilities from the 1960s onwards meant that the administration increasingly became centralised ${ }^{84}$. In fact, during the presidency of Nasir, the prime minister made the final selection for government jobs after being presented with three short-listed candidates (Zaki \& Parakh, 2008, p. 86). This high level of centralisation is perhaps the most fundamental feature of public administration in the Maldives. On the one hand, the high degree of centralisation arguably brought substantial benefits that include uniform budgetary processes and expenditure in the form of standardisation and redistribution of government revenue to all parts of the archipelago irrespective of the level of economic activities. On the other hand, it also meant referral was made to Male' for decisions on even the most trivial matters.

Following the re-election of President Gayoom for a fourth consecutive term in November 1993, some degree of devolutionary efforts commenced after years of centralisation of the administration and authority in the PO. Until then, even trivial financial issues had to be reported to the PO while the Ministry of Finance and Treasury (MOFT) played only a peripheral role. Under the structural reforms implemented in 1993 most government organisations were placed under sector ministries rather than under the direct supervision of the PO. Some administrative powers were also delegated to ministerial level resulting in quicker decision-making. Consequently, a number of functions at the PO, including preparation of the national budget and scholarship management, were delegated to the relevant ministries (I. Mohamed, 2005, p. 145). However, the extent of delegation did not go far enough and, according to a senior former government official, the ministers themselves lacked authority and were considered merely as "elevated secretaries" who had to report to the PO regularly (Interviewee FO9).

\footnotetext{
${ }^{84}$ One such example is the abolition of the elected atoll committees. Under the "reforms" of 1975 , those committees that existed under the 1968 constitution were abolished and the post of Atholhuverin was appointed by the central government (Phadnis \& Luithui, 1985). (Also see section 4.3.1)
} 
During recent decades, centralisation has been evident mostly in the administration of the atolls. Until its abolition in November 2008, the Ministry of Atolls Development (MoAD) had overall responsibility for administering the atolls. That included socio-economic development as well as administration. As pointed out previously (section 5.2), each inhabited island was headed by a katheebu ${ }^{85}$, who reported to the state representative at each atoll, atholhuverin, who, in turn, reported to the minister. This long chain of command created bottlenecks which were considered to be one of the reasons for limited development in the atolls: often katheebu would be reluctant to take decisions unless these were authorised through the correct chain of command (Interviewee GO5). In this regard, Maloney (1980, p. $185)$ recalls the following incident while visiting one island:

On one occasion I wished to take a photo of a ceremony inside a mosque; I knew I could not go in, but wished to stand outside and take it. The mudimu said to ask the kuda katibu. The kuda katibu said to ask the katibu. The katibu said to ask the atoll office (on another island!). This was a new situation for them, and as they were completely beholden to the atoll office and Male', they would not make a decision.

\subsubsection{Inadequate performance management system.}

The fact that the personnel management function was a prerogative of the executive continually hindered the establishment of a merit-based system. It meant that there were a wide range of exceptions to the general rules in appointment, transfer, and promotion. This was because, in most cases, a minister personally made all important decisions on personnel management and acted as a "glorified human resource manager" (Interviewee GO5). Such practices were further complicated by a number of peculiarities in the administrative culture (see section 5.4.6). Firstly, a widespread conception existed that jobs in the public sector were given for life (Interviewee FO3). Such notions prevented the evolution of a performance-oriented public service because of the reluctance to sack the non-performers. As one

\footnotetext{
${ }^{85}$ From the recent past, katheebu (island headman) is appointed by the central government. Most islands have one or more kuda katheebu (assistant to the katheebu) as well. However, under the democratic reforms and with the election of councils to each island and each atoll, these traditional titles are now being phased out.
} 
interviewee said, the Maldives did not have a culture of sacking staff or making them redundant (Interviewee FO6). Dismissals were very rare. Though a significant number of staff were transferred from one organisation to another, some of whom were given no job responsibilities, almost none were sacked and every individual was duly paid (Interviewee FO6). Secondly, the vested authority of personnel management under the control of political masters meant that pleasing the political appointees was the prime objective rather than improving job performance. Though job qualifications on the classification ladder were pre-determined, bypassing of those requirements was common.

In the past, efforts to link performance to financial incentives had failed (Asim, 2001). Introduction of a performance appraisal system in 1996 linked to annual salary increments was abandoned after three years as almost everyone was found to be eligible for the increment. A revamped appraisal system was introduced by the government in 2002. However, factors such as the absence of an independent CS, lack of political support, and lack of rewards were considered to be the prime reasons for a failure to institutionalise the new appraisal system (Faizal, 2005). From late 2003, promotions, at times with jumps of three or more levels, were handed to selected government employees. Consequently, calls to designate a CS independent from all political influences grew significantly.

\subsubsection{Administrative culture.}

The Maldivian Public Service reflects features usually evident in closely-knit communities. Most public servants know each other and are related through several means, such as neighbourliness, community activities, friendship or blood relations. Latheef (1993, p. 31) points out that, "the probability of one becoming some form of acquaintance with, or close relation to a key player in a given situation is many times greater in the Maldives than in most societies". Close personal relations can be viewed through a positive lens: they can lead to cooperation in public life. As Zameer (1994) states, such closeness may be considered to be a facilitating force in bringing about better performance in public service. However, such connections can have negative effects as well: relationships can contribute to inefficiency and corrupt practices, and also make objective assessments in the work environment a difficult 
task as managers are often reluctant to take action that may disappoint fellow staff (Asim, 2002).

The inability of a government job to adequately support a family has created a culture where individuals are allowed to have multiple jobs, in many cases one within the government and another in the private sector. As mentioned in Chapter Four (section 4.3.2), such practices existed even in the legislature as well as the bureaucracy. Phadnis and Luithui (1985, p. 43) state, in the Maldives, "with virtually half the legislators being busy simultaneously in administrative work, the initiation and implementation of public policies get intertwined to a greater extent than it does in other states of South Asia". As a result, the possibility of conflict of interest grows significantly. Complaints about some civil servants doing personal work during office hours are common (Interviewee PL1). It is also common for someone to go out on personal errands and take a lot of time to return to work (Interviewee PL1). This culture of wandering off from work during office hours hinders the creation of a professional public service. Over the years, such practices had magnified the need to create a professional CS where a civil servant will not have another job obligation to fulfill.

\subsubsection{Growth in public sector.}

The modernisation of the nation since gaining independence has predominantly been driven by the government. Mostly developments in the fisheries sector and the introduction of tourism in the 1970 s created the need to strengthen the regulatory functions of the government. State services such as immigration, customs, tax collection and many other areas had to be strengthened and developed in order to keep pace with the developments in economy and international trade. The significant growth that the nation experienced since the early 1980s also contributed to the growth of the public sector (see figure 5.2). Consequently, expenditure on salaries and wages from the state budgets also increased substantially - from 13.6\% in 1995 (Maldives Monetary Authority, 2001, p. 44) to 33\% in 2008 (International Monetary Fund, 2009, p. 14). 
Figure 5.2: Growth of the public service

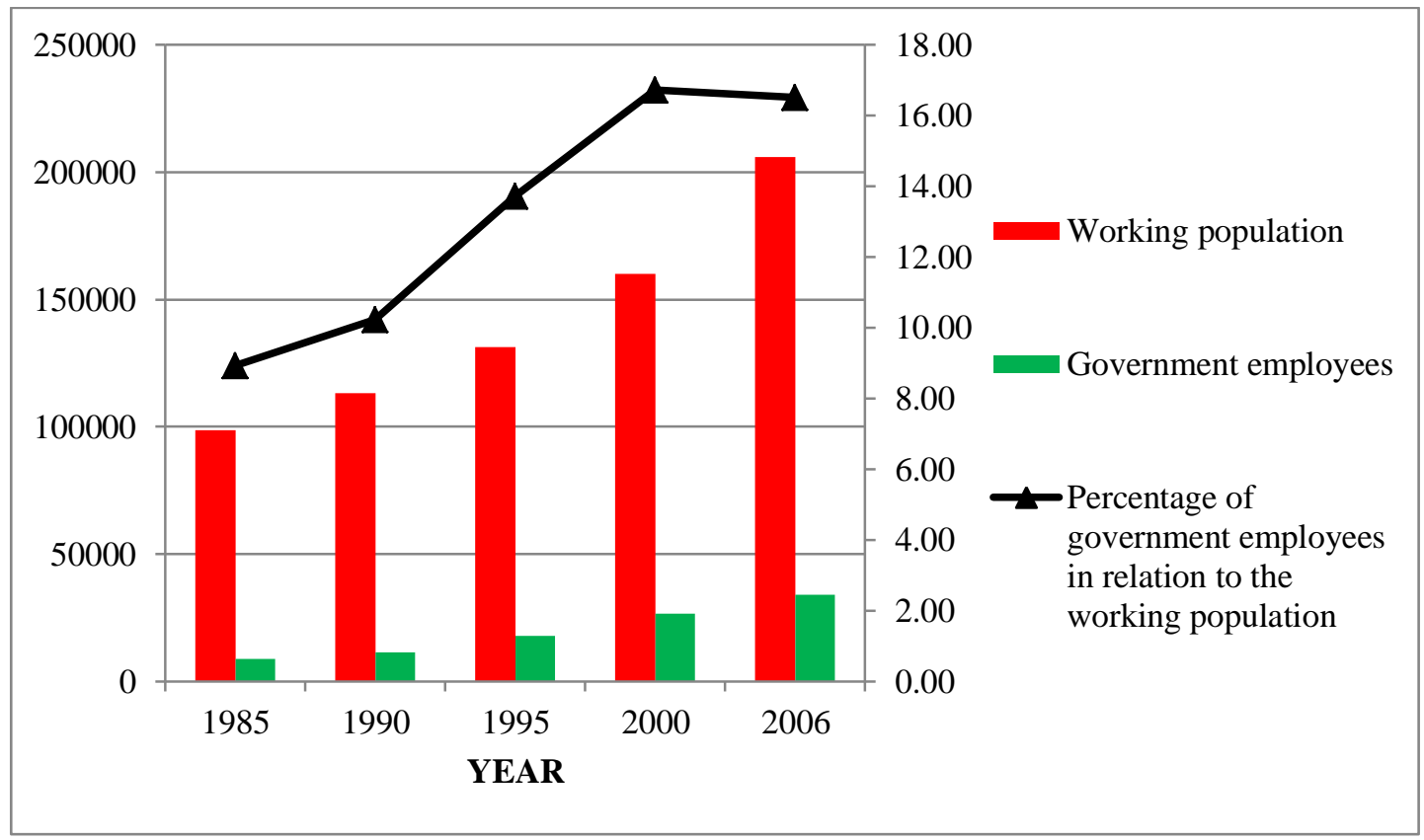

Source: MPND (2005a, 2007b)

Note: This figure shows the increase in the number of government employees in relations to the total working population (that is age 15 and above). Government Employees represent public servants prior to the establishment of the CS and other statutory organisations. The figures include both permanent and temporary government employees, expatriates hired by the government, and the government employees working at state owned enterprises.

Apart from the expansion in the public service due to economic growth, many other specific factors contributed. Islandness was a factor: the geographical dispersion of the islands meant that each island community has had to function as a distinct administrative unit. The provision of all basic facilities such as school, hospital, mosque, judicial court, and administrative office in each and every island was considered to be a state function. The public expects the government to provide all services (Zameer, 1994, p. 32). Though privately built schools and mosques have been in existence for many decades, the responsibility of manning those organisations was often handed over to the government. All the basic personnel had to be employed despite not having adequate workloads as they had to serve a small population base (see table 4.1) in most cases (Interviewee FO2). Maldivians demand all such services in their own islands and are reluctant to travel to other islands to receive them (Interviewee GO7). 
In addition to the basic services provided by the state, other sectors such as arts, sports, and culture, which are primarily served by CSOs in most countries, had to be spearheaded by the government in the Maldives. Especially during the infant stages in the development of these sectors, the government had to provide the facilities and personnel to operate the necessary activities. The extent of the burden on the government is also evident in that it is the government that has had to train and employ personnel to bury the dead on every island (Interviewee GO1). Supply of personnel to all corners of the nation to promote and operate all these activities and functions has also had a profound effect on the rise in numbers in public employment (Interviewee GO6).

The high birth rate throughout the 1970s until the beginning of the new millennium (refer to figures 4.3 and 4.4) resulted in a significant jump in the number of school leavers during the 1980s and 1990s. Though the tourism sector was booming, the inability of that sector to absorb substantial numbers of school leavers, along with an inability to significantly develop other economic sectors gave rise to a potential leap in the unemployment rate. To avoid having a society with a large unemployed youth population, the government resorted to absorbing the majority of the school leavers into the public sector workforce. Though there was no apparent need for an increase in jobs in some public organisations, the government employed people to work in them regardless. The nation's social security system was weak with no universal pension $^{86}$, social benefit, or mandatory retirement age. In such an environment, the employment provided by the government was seen as an indirect social benefit (Interviewees CV1, FO4, FO5, FO8, FO9). Wages from government employment were often used to support immediate and extended family members.

\footnotetext{
${ }^{86}$ The Maldives had an unusual combination of employment for life and a pension payable while still in service. The 1968 constitution guaranteed a pension of half of the basic salary for those who had served the government for a consecutive term of 20 years. Through regulations, this provision was extended to 40 years of consecutive service at which the person was entitled for a full basic salary as pension - once again while still in service. The 1998 constitution extended the provision for pension rights to all employees - public and private. This constitution referred to a future pension law. However, that law was not formulated until 2009. As a result, a pension was provided only to government employees - once again while still in service. The 20 years and 40 years on-the-service pension schemes were fully funded by the government budget without any contribution from the employee. This scheme was abandoned with the inception of the CS.
} 
Especially in the island communities where economic activities were significantly limited, the provision of jobs as a social benefit created adverse effects. The employment of several members of a single family in various capacities in the island has been common practice. As a senior government official puts it, in some islands it is "like family-based rule systems" (Interviewee GO2) where the control of all or most of the island affairs lies with a single or few families (Interviewee FO3). It was also common for influential officials to use their authority to grant jobs to friends and relatives (Interviewee FO2). Recruitment based on favours rather than merit was common (Interviewee FO11).

As indicated previously (section 5.4.5), the Maldives did not have a culture where redundant and non-performers were dismissed from the public payroll. It was relatively common, mostly in the outer islands, for some individuals to remain on the government payroll until they were deceased, despite their old age and inability to work (Faizal, 2005). The societal status of such individuals and the influence they held within the island communities meant that the government was eager to garner public support through such individuals. Such practices also contributed significantly to the high personnel cost.

Yet another cause of the high rise in the numbers in public employment was the over-specialisation of tasks. The inability to develop professional public servants created an environment of following the job description to the letter. The reluctance or refusal by a significant proportion of public servants to undertake additional responsibilities, especially those that arose unexpectedly, forced employers to hire additional staff for those tasks. Furthermore, a lack of organisational planning in combining inter-related tasks was also considered a factor in the rise in the numbers in public employment. As one former senior official said, at a typical government department's reception, "you might find a person to receive the mail, another to open the mail, and another to record it" (Interviewee FO2, Aminath Nihan Translation).

\subsubsection{Towards a civil service.}

A significant move towards codifying the CS began with the deployment of two projects from 1981 to 1984 . The first concentrated on improving the personnel 
system, which included drafting a CS code and the formulation of a job classification and pay system; and the second focused on improving government organisation and administrative systems with specific emphasis on personnel administration (Norcross, 1984). Although rules and guidelines on these aspects had been evolving for years, these projects aimed to make them more comprehensive.

One of the main outcomes of the early reform initiatives was establishment of the National Office of Personnel and Administrative Reform (NOPAR) on November 1, 1982. NOPAR operated within the framework of the PO. This key organisation assumed a leadership role in introducing, fostering, and guiding administrative reform with sound personnel management in the CS (Norcross, 1984). The positive impact of these reforms was evident almost immediately. The WB reported in early 1984 that under the aegis of NOPAR, an organisational restructuring resulted in a clear definition of responsibilities held, helping avoid duplication and enabling an adequate coordination of functions (WB, 1984).

Over the next decades, various reform projects were launched. The projects focused on streamlining the government machinery, improving the personnel management system, creating a service-centered public service, and improving the performance management system. However, the impact of such reforms on establishing a professional public service was limited and there were also relative failures at times (Asim, 2001). Although the groundwork to establish a professional CS had been completed, there was a degree of reluctance to overcome the final hurdles to formulate a statutory CS. For instance, there was a lack of political will to press ahead with robust and vigorous reform recommendations to implement "best practice" in personnel management outlined under the numerous projects.

The reforms of the 1980s and the 1990s did help develop fundamental areas of administration; but there was then a need to move forward into a different stage. The establishment of the Public Service Division (PSD) in 1999 was the response. This organisation was created after NOPAR was disestablished in the early 1990s. The PSD also operated within the framework of the PO. The new organisation conducted several seminars, workshops, and training programmes on modern public service reform initiatives such as strategic planning, customer service, human resource 
development planning, financial management reform, leadership, change management, and knowledge management (Alam \& Jasimuddin 2006, p. 29). Though not all these reform initiatives are considered a success (Alam \& Jasimuddin 2006, p. 65; Asim 2001), significant improvements were visible such as a greater focus on customer service, better planning, and records management. Through the PSD, vital changes were being implemented in the public service that eventually led to a transition towards a statutory CS.

By the start of the twenty-first century, comprehensive regulations governing government employees were in place. Most aspects of the regulations have seen incremental changes over the years. The Government Employees' Regulation of 2000 published by the PSD covered all aspects governing the affairs of personnel management and general rules. Some of the main areas covered in the Regulation include: a code of conduct; procedures for recruitment, appointment, transfer, dismissal, and rewards for permanent and temporary employees; disciplinary measures; procedures for training and service bonds; and record keeping procedures (PO, 2000). Regardless of such extensive regulations, a high degree of centralisation existed with PSD authorisation needed on most aspects relating to government employees. Thus, until the inception of the CSC, the PO continued to oversee the management of government personnel.

One important aspect, a grievance mechanism, was lacking in the 2000 Regulation. As a general rule, anyone could appeal directly to the president in writing and could submit a case to the civil court. Although such provisions have remained for many years, court cases on employment-related issues were rare due to reasons such as lack of awareness of legal rights, high legal fees, and too few lawyers. As a result, the existing grievance handling mechanism was considered inadequate to uphold the rights of public employees.

Though recommendations were made as early as 1979 to change the administrative structure to accommodate a statutory CS (Banerjee, 1979), the provisions of the 1968 
law $^{87}$ (see section 5.3) remained until the inception of the CS Act. Until then, the reluctance of the government to provide proper institutional status and functional autonomy to the CS was seen by some as an attempt to maintain political control over government officials (Interviewee FO3). This ultimately led to the formulation of the CS through "revolutionary" means (Interviewee GO4).

\subsection{Conclusion}

This chapter has shown that the Maldives have had a functional government for centuries. It is safe to speculate that Maldivians had contact with modes of governance and practices from other nations for several centuries, resulting in some borrowing from Arab countries and the South Asian neighbours particularly in the detailed regulation of bureaucratic life. However, in the absence of colonial imposition of a foreign system of government, the locals borrowed only those features which they saw as being compatible with the Maldivian way of administration. Smallness and islandness was factors that contributed in such developments. Hence several writers have declared that it was a locally evolved system. One interviewee said, "it's a pot of bits and pieces that are brought from various systems" (Interviewee FO7).

With the developments of the last half of the twentieth century, the rulers of the country had several opportunities to establish a professional CS and there was an increasingly detailed codification of the administration of government employment, but within the principle of virtually absolute presidential discretion. Thus, arguably, the desire to exercise political control over the public service along with the inadequate strategies of the government compounded by an inadequate administrative culture resulted in an unproductive, unprofessional, and politicallydriven public service. As a result, once democracy dawned on the nation, reform of the state administration was a key demand, especially by the public service frustrated with mismanagement practices. Establishment of a statutory CS thus became one of the components of the democratic reform agenda. Significant progress on the CS

\footnotetext{
${ }^{87}$ Amendments were brought to the law in 1990 to grant greater responsibilities to the ministers and senior public servants (Article 7-9). However, at the implementation level, only insignificant changes were observed following those amendments.
} 
reform began in October 2005 when a parliamentarian aligned with the government submitted a CS bill. The next chapter focuses on the formulation of the CS model in the Maldives. 


\section{CHAPTER 6: FORMULATION OF THE CIVIL SERVICE MODEL}

\subsection{Introduction}

Establishment of a statutory CS with autonomy from the political executive in matters of employment is a new initiative in the history of public affairs in the Maldives. Chapter Four covers the drivers of democratisation and argues that it was democratisation that made the CS reform a "necessity". Chapter Five traces the history of the formalisation of public employment but stops before an analysis of the specific drivers of the CS Act. This chapter continues from that point onward and examines the route of the CS bill to the adopted Maldivian Civil Service Model.

As mentioned in the first chapter (section 1.5.2), most nations in contemporary times opt to define the scope, parameters, values, and responsibilities of the CS in law. By using the terms "civil service model" and "civil service system" interchangeably, this chapter aims to present the route towards the formulation of a CS Act and the main aspects of the CS model (based on the Act and the regulations) adopted in the Maldives, including possible influences from overseas nations during the process. In this regard, a structured narrative of the process in the legislature that led to the enactment of a law governing the CS in the Maldives is presented. The analysis draws on the explanations of policy development processes and doctrines of the CS in a polity that was discussed in Chapter Two (sections 2.4 and 2.6). The analysis reveals that the Maldivian CS Model is a combination of three main forces: 1) the rule-based culture that was inherited prior to the establishment of the statutory CS, 2) the intense political environment present during the passing of the bill that opted for a model that is relatively independent of the political executive, and 3) overseas practices and models of CS.

The chapter is divided into eight main sections. The first section outlines the submission of the bill to the parliament, followed by identification of the main actors significantly impacting the policy decisions shaping the bill. The third section presents the amendments proposed to the bill. Sections four and five provide the rationale for support of the bill from both opposition and government through to its enactment. The processes followed in passing the bill are outlined in section six. The 
seventh section presents the CS model of the Maldives. The last section examines possible influences from overseas CS systems during the formulation of the Maldivian Civil Service Model. The chapter concludes by summarising the CS model of the Maldives.

\subsection{Submission of a civil service bill}

As examined in the previous chapter, regardless of the existence of a statutory CS per se, the institutional setup of a CS has been developing in the Maldives for the last few decades. The political reforms that started to sweep through the nation were particularly aimed at constraining the powers of the political executive; both government and opposition saw a statutory CS that was relatively independent of the political executive as an element of these changes. As one interviewee said, "as soon as we had liberal democracy and specific cadre of politicians, we needed independent people who would run the government irrespective of who is in power" (Interviewee FO8).

Though political reforms were initiated towards the end of 2003, and the government acknowledged the importance of a CS, a government bill did not materialise for submission to the parliament. This was despite the PSD working on drafting a CS bill during 2004 and 2005. Such delays on the part of the government prompted Ahmed Nazim, the MP from Mulaku Atoll, to submit a public bill to the parliament himself. Although it was not an official government bill, it had some support within the government. The co-sponsor of the bill was Ahmed Thasmeen Ali, the MP from Baa Atoll, who was also the Minister of Home Affairs during that period. Ahmed Nazim was within the ruling party and soon after submitting the bill, on October 30, 2005, he was appointed as the Minister of State for Higher Education, Employment, and Social Security.

At the time of submission of the CS bill, private member bills were rare in the Maldivian polity. Although MPs could submit their own bills, the firm grip by the government on the legislature ensured that almost all bills were submitted by the government itself. This trend started to change by the liberalisation movement and the election of a new majlis in early 2005 that included several opposition members. 
As the influence of opposition MPs grew, the ruling party was eager to occupy the time slots allocated for private member bills, which at that time were being used mostly by opposition MPs (Interviewee FO4). As the CS bill was submitted by a faction of senior officials within the ruling elite, openly opposing the bill was not an option for the government. The first reading of the bill was held on October 27, 2005.

The submission of a CS bill was described as timely and necessary by most parliamentarians. Prior to the debate, the speaker acknowledged receiving a petition on June 19, 2005, signed by a number of senior government officials demanding the establishment of a CS independent of the political executive. The need was amplified with the introduction of political parties in June 2005 (Interviewees CV1, FO7, FO8, GO4, GO5, GO6). During the submission speech, Nazim reiterated the importance of having an independent CS in a multi-party political environment. On November 14,2005 , the second day of the first reading, parliament voted to send the bill to the social committee of the parliament.

\subsection{Policy actors}

The actors involved during the formulation of the bill as well as during the course of the bill in the parliament were limited in number. No public consultation on the bill was undertaken. During the submission speech on October 27, 2005, Ahmed Nazim said:

Although the legal drafting of this bill is quite similar to the bills submitted by the government, I would like to mention that no government contribution was involved in drafting of the bill. Although I unofficially approached the government to submit comments on the bill, the government did not respond. (Nazim, 2005a, translation)

According to him, a number of lawyers were involved in drafting of the bill (Nazim, 2005a). 
From November 14, 2005 to December 11, 2006, the bill passed through the parliamentary committee stage. Before the committee started to debate the bill, a new regulation of parliamentary procedures came into effect which required the bill to be passed on to the National Development Committee ${ }^{88}$. From July 16, 2006 a total of 29 committee meetings were held until a report was finalised on December 11, 2006. During this period, technical personnel from the PSD attended the parliamentary committee to answer questions. The PO also sent written comments to the parliament on November 27, 2006. The report compiled by the committee and the amendments to the bill were submitted to the parliament floor on December 19, 2006. The chairperson also revealed that public opinion on the bill was sought through CSOs (Shareef, 2006). However, there was not much consultation with government employees (Interviewee FO11) affected by the legislation.

\subsection{Amendments to the civil service bill}

There were some significant changes to the bill between the original proposal and the final outcome, particularly seeking to maintain the principle of neutral competence and the political neutrality of the CS. How these aspects were viewed from the perspective of the opposition and the government is outlined from sections 6.5 to 6.7. Section 6.8 examines the CS model of the Maldives that covers principles such as neutral competence and political neutrality.

Amendments to the CS bill were proposed in two phases. During the first phase, the main changes brought during the committee stage include changes initiated by the committee and changes proposed by the PO. In the second phase, MPs submitted amendments during the second reading of the bill (that was after the committee submitted the revised bill to the floor). These changes were submitted in the parliamentary sessions of December 19, 2006 and March 7, 2007.

\footnotetext{
${ }^{88}$ The Committee comprised seven MPs: North Ari Atoll MP Ahmed Zubair; South Ari Atoll MP Abdul Muhsin Abdulla; South Nilandhe Atoll MP Ahmed Nashid; South Nilandhe Atoll MP Ahmed Siyam Mohamed; Addu Atoll MP Ibrahim Shareef; North Miladhunmathi MP Mohamed Hussain; South Huvadhu Atoll MP Ahmed Zahir.
} 


\subsubsection{Functions of civil service commission.}

As mentioned in Chapter Two (section 2.3.3), the CS is usually defined by its functions, methods of appointment, legal status, and scope. The extent of such parameters can vary across countries. The CSC in the Maldives were to be given wide-ranging functions and powers regarding the CS. Specifying the functions explicitly in legislation were thus considered important.

The functions of the CSC as stated in the bill include the management of personnel for the entire CS (including appointment, dismissal, transfer, and setting salaries), regulation of the CS (including regulation for personnel management and code of conduct) and investigation of grievances of civil servants. One of the amendments proposed by the PO was to split these functions after the establishment of the CS so that the CSC retains only the management of the personnel function. The reason stated by the PO for such a split was:

to confer good governance, these three roles should operate independently. ....it might be difficult to make such a distinction at the beginning of the implementation of the Act. So a proposal can be submitted to the majlis after a specified time following the establishment of the commission. (PO Letter, 2006, translation)

In other words, the PO suggested continuing with the combined functions in the initial phase of the CSC, but to submit an amendment to the majlis later, to assign each function to a distinct authority. The PO did not specify who should be responsible for the roles that could be removed from the CSC. The committee did not accept the suggestion from the PO, arguably because it felt the government was attempting to keep one or more functions of the CS within the control of the president. Due to the comprehensive political reforms that were underway during that period, opposition MPs especially, were not willing to grant the government such a leverage to segregate the functions of the CS.

Table 6.1 summarises the proposed amendments and the final outcome regarding the functions of the CSC. 
Table 6.1: Functions of the Civil Service Commission

\begin{tabular}{|c|c|c|c|}
\hline $\begin{array}{l}\text { Original proposal in } \\
\text { the bill }\end{array}$ & $\begin{array}{c}\text { Changes proposed } \\
\text { by the PO }\end{array}$ & $\begin{array}{c}\text { Changes made by the } \\
\text { committee }\end{array}$ & Final outcome \\
\hline $\begin{array}{l}\text { Personnel } \\
\text { management of the } \\
\text { CS, regulating the } \\
\text { CS, grievance } \\
\text { handling. }\end{array}$ & $\begin{array}{l}\text { Retain personnel } \\
\text { management } \\
\text { function at the CSC } \\
\text { and move the other } \\
\text { two functions to } \\
\text { separate } \\
\text { organisations. }\end{array}$ & $\begin{array}{l}\text { Reject the proposal } \\
\text { of the PO and retain } \\
\text { the original } \\
\text { arrangements in the } \\
\text { bill. }\end{array}$ & $\begin{array}{l}\text { As proposed in the } \\
\text { bill. }\end{array}$ \\
\hline
\end{tabular}

\subsubsection{Scope of civil service.}

Beyond the general principle that officials exercise the legal authority of the state, classical Weberian bureaucracy does not offer any more specific guidance on what public organisations should be included in the scope of the CS. The initial drafters of the Maldivian CS bill did not have strict preferences on this aspect and relied, to some extent, on how other countries determined the scope of their CS (see section 6.9). They also relied on the past organisational arrangements in the Maldives where the government had provided most welfare services (see section 5.4.7). However, determining the scope of the Maldivian CS turned out to be the most contentious issue in the parliament.

Rather than defining scope of the CS by identifying the organisations and posts to be included in it, article 3 of the bill listed the organisations and posts that were to be excluded, thereby implying that all other state organisations and posts were part of the CS.

This list was the focus of the battle over the scope of the CS. Opposition MPs were adamant about minimising its exclusions because they wanted to leave as few public employees as possible subject to more direct political control. 
The most contentious point was the exclusion of heads of island offices (katheebu) from the CS in the original bill. Among the many voices against such exclusion, Hassan Afeef, the MP from Kolhumadulu, said:

At the moment, the heads of the island offices work under a ministry and follow their instructions, which is why I do not believe they can be exempted from civil service. But if they are elected positions, as the Maldivian people wish, then for sure, they will not be part of the civil service. (Afeef, 2005, translation)

Exclusion of the police force from the CS also proved to be controversial because, as stated in Chapter Four (section 4.3.3), it was only in 2004 that police were separated from the military and made a "civilian" force. There was a growing fear among the MPs that the government was attempting to politicise the police ${ }^{89}$ by exempting them from the CS Act.

Yet another highly debated issue was the exclusion of political advisers from the CS. Afeef (2005) stated in the parliamentary debates, such appointments could be quite extensive and the CS could be distorted if the responsibilities of these political advisers coincided with the work of the CS. Government eventually gave in to most opposition demands as it had other mechanisms at its disposal to make political appointments once the new constitution came into place.

Questions were also raised regarding the inclusion of judges ${ }^{90}$ (except the chief justice who was excluded under article 42(a) of the constitution - see tables 4.2, 6.2) within the scope of the CS (Hussain, 2006). The system of government to be enshrined in the new constitution - presidentialism or parliamentarism, was not yet determined (see sections 4.3.3 and 6.7). Whatever the future form of government, all judges were expected to be independent of the political executive, an issue that was

\footnotetext{
${ }^{89}$ At the time of CS bill, a separate Police Act did not exist. A Police Act came into operation from August 5, 2008. Under the Act, police officers are not part of the CS.

${ }^{90}$ A CS that includes officials such as judges and police would be consistent with the principle of including all those who exercise public authority. However, it raises another principle - that there are some matters on which the civil servant is accountable to the law but not subject to the discretion of a minister.
} 
not addressed in the bill. As the issue of judges was not addressed appropriately, it eventually turned out to be problematic for the government (see section 7.4.1).

The final outcome on specifying the scope of the CS was predominantly a political decision based on compromise among the MPs after the government gave in to most of the opposition demands. Table 6.2 summarises the changes to the CS bill during the different stages.

Table 6.2: Changes to the scope of civil service

\begin{tabular}{|c|c|c|c|}
\hline $\begin{array}{c}\text { Original proposal in } \\
\text { the bill }\end{array}$ & $\begin{array}{c}\text { Changes proposed } \\
\text { by the PO }\end{array}$ & $\begin{array}{c}\text { Changes made by the } \\
\text { committee }\end{array}$ & Final outcome \\
\hline $\begin{array}{l}\text { Positions excluded } \\
\text { from the CS: 1) } \\
\text { positions appointed } \\
\text { and dismissed by the } \\
\text { president as per } \\
\text { section } 42 \text { (a) of the } \\
\text { constitution 91 2) } \\
\text { deputy ministers; } 3 \text { ) } \\
\text { secretary general of } \\
\text { parliament; 4) retired } \\
\text { state dignitaries; 5) } \\
\text { the Maldivian army; } \\
6 \text { ) police; 7) head of } \\
\text { island offices; } 8) \\
\text { employees of state } \\
\text { enterprises; and 9) } \\
\text { assistants, advisers, } \\
\text { and public relation } \\
\text { officers of the posts } \\
\text { mentioned in 1, 2, } \\
\text { and 3. }\end{array}$ & $\begin{array}{l}\text { In addition to deputy } \\
\text { ministers, include a } \\
\text { general provision } \\
\text { where other posts } \\
\text { that are designated } \\
\text { as equivalent to the } \\
\text { post of deputy } \\
\text { minister are } \\
\text { excluded from the } \\
\text { CS. }\end{array}$ & $\begin{array}{l}\text { Committee decided } \\
\text { to remove numbers } \\
3,4,6,7 \text {, and } 9 \text { from } \\
\text { the original list. } \\
\text { They also added two } \\
\text { more to the list: } \\
\text { executive secretary } \\
\text { to the president and } \\
\text { positions excluded } \\
\text { from the CS by any } \\
\text { other law. } \\
\text { Committee } \\
\text { rejected also } \\
\text { amendment proposed } \\
\text { by the PO. }\end{array}$ & $\begin{array}{l}\text { Positions excluded } \\
\text { from the CS: 1) } \\
\text { positions appointed } \\
\text { and dismissed by the } \\
\text { president as per } \\
\text { section } 42 \text { (a) of the } \\
\text { constitution; } \\
\text { deputy ministers; } 3 \text { ) } \\
\text { executive secretary } \\
\text { to the president; 4) } \\
\text { the Maldivian army; } \\
\text { 5) employees of state } \\
\text { enterprises ; and 6) } \\
\text { positions excluded } \\
\text { from the CS by any } \\
\text { other law. }\end{array}$ \\
\hline
\end{tabular}

\footnotetext{
${ }^{91}$ Reference is made here to the 1998 constitution. Under article 42 (a), the president shall have the power for appointment and removal from office in accordance with the constitution, of the vicepresident, chief justice, speaker and deputy speaker of the people's majlis, ministers, attorney general, representatives sent abroad with special privileges on behalf of the state of the Maldives, atoll chiefs, judges, auditor-general, and commissioner of elections.
} 


\subsubsection{Qualifications and term limits of the civil service commissioners.}

Qualifications and term limits of commissioners ${ }^{92}$ also vary from country to country and no universal standard is evident. The Maldivian CS bill initially specified that the commissioners should have achieved higher education in the field of public administration and gained experience in that field (Civil Service Bill, 2005, Article 10b). However, it did not specify the minimum academic qualification or any detail on how to measure the level of experience. At the time of the bill, it was believed that only a few Maldivians had any higher education in public administration. As a result, the PO proposed changing the requirement to include minimum experience of ten years in a managerial position after completion of a bachelor's degree, irrespective of the field (PO Letter, 2006). This opened the door for professionals from all fields to apply for the post of commissioners.

Initially, the bill provided for the commissioners to be appointed for a maximum of two terms of five years each (Civil Service Bill, 2005, Article 13). The PO suggested that since the bill specified procedures to remove ${ }^{93}$ the commissioners, there was little need to impose a maximum term limit and suggested including a provision where the commissioners could be re-instated every five years without a specific term $\operatorname{limit}^{94}$ (PO Letter, 2006). The committee accepted the recommendation and included it in the amended bill that was presented to the majlis floor on December 19, 2006. Subsequently, Abbas Ibrahim, MP for Huvadhu Atoll Dhekunuburi, submitted an amendment to limit the membership to two terms. This amendment failed during the voting on March 27, 2007.

\footnotetext{
${ }^{92}$ According to the CS Act that was originally passed by the majlis, members of the CSC were to be appointed by the president with the consent of the majlis. In the event the majlis rejected a candidate, the president had to send a replacement name. When the CSC commissioners were first appointed in 2007, the majlis rejected several candidates and the president had to send a total of 21 candidates in three rounds. A total of five commissioners were appointed.

${ }^{93}$ Provisions for removal of commissioners were given in article 11 of the CS bill. According to it, commissioners should be removed from the post by the president if the majlis votes to remove a commissioner. Also the president should remove a commissioner when he/she no longer fulfils the qualifications of the commissioners mentioned in the bill or becomes bankrupt.

${ }^{94}$ Not imposing a maximum of two term limit appears to be contradictory to the 2008 constitution that came after the CS was established. Article 183 of the constitution states that "A member of the Civil Service Commission shall be appointed for one term of five years. The People's Majlis can approve the renewal of the appointment for an additional term of not more than five years". Though CSC has recommended to the majlis to amend the Act to align it with the constitution, the majlis has so far not attended to this matter.
} 
Another recommendation put to parliament was reduction of the minimum age of the commissioners from 35 to 30 years (A. Ahmed, 2005; Didi, 2005). The justification for the proposed change was that a significant majority of the population was below the age of 30 (see figure 4.4). This change was not deemed controversial and the committee agreed.

Table 6.3 summarises the changes during the different stages.

Table 6.3: Changes to the qualifications and term limits of commissioners

\begin{tabular}{|c|c|c|c|c|}
\hline $\begin{array}{c}\text { Original } \\
\text { proposal in the } \\
\text { bill }\end{array}$ & $\begin{array}{c}\text { Changes } \\
\text { proposed by the } \\
\text { PO }\end{array}$ & $\begin{array}{c}\text { Changes made } \\
\text { by the } \\
\text { committee }\end{array}$ & $\begin{array}{c}\text { Proposals } \\
\text { during the } \\
\text { second reading }\end{array}$ & Final outcome \\
\hline $\begin{array}{l}\text { Appointed by } \\
\text { the president } \\
\text { with the consent } \\
\text { of the majlis. } \\
\text { Commissioners } \\
\text { should have } \\
\text { acquired higher } \\
\text { education in the } \\
\text { field of public } \\
\text { administration } \\
\text { and gained } \\
\text { experience in } \\
\text { the field. } \\
\text { Maximum of } \\
\text { two terms with } \\
\text { five years each. }\end{array}$ & $\begin{array}{l}\text { Change the } \\
\text { qualifications: } \\
\text { work in a } \\
\text { managerial } \\
\text { position for } \\
\text { more than ten } \\
\text { years after } \\
\text { completion of } \\
\text { bachelor's } \\
\text { degree. Also } \\
\text { remove the } \\
\text { maximum term } \\
\text { limits. }\end{array}$ & $\begin{array}{l}\text { Committee } \\
\text { accepted the } \\
\text { changes } \\
\text { proposed by the } \\
\text { PO and thereby } \\
\text { removed the } \\
\text { original } \\
\text { qualifications in } \\
\text { the bill and the } \\
\text { maximum term } \\
\text { limits. They } \\
\text { also added } \\
\text { detail process } \\
\text { on how the } \\
\text { president gets } \\
\text { the consent of } \\
\text { majlis. }\end{array}$ & $\begin{array}{l}\text { Set a maximum } \\
\text { term limit of } \\
\text { two terms, five } \\
\text { years each. } \\
\text { Reduce the } \\
\text { minimum age } \\
\text { of the } \\
\text { commissioners } \\
\text { from } 35 \text { to } 30 \\
\text { years. }\end{array}$ & $\begin{array}{l}\text { Changes made } \\
\text { by the } \\
\text { committee were } \\
\text { approved. Age } \\
\text { limit of } \\
\text { commissioners } \\
\text { was also } \\
\text { reduced to a } \\
\text { minimum of } 30 \\
\text { years. No } \\
\text { maximum term } \\
\text { limits for the } \\
\text { commissioners. }\end{array}$ \\
\hline
\end{tabular}

\subsubsection{Retirement age.}

One of the key features in classical Weberian bureaucracy is the expectation that the civil servant be employed within the CS until retirement, subject to adequate performance. Although many countries have a mandatory retirement age, the 
Maldives was an exception. Consequently, introduction of a mandatory retirement age for the Maldivian CS became the most sensitive issue during the debates of the CS bill, mainly because it was a new concept for a society accustomed to the idea that civil servants held their job for life.

As well as unlimited tenure, government employees could receive a pension while still in service. Although the 1998 constitution referred to a future pension law that would cover both the public and private sector staff, this law did not exist during the time of the CS bill. The CS bill proposed to introduce a mandatory retirement age and a government pension upon retirement. Government argued that a pension law had to come in before such provisions could be included in the CS bill. So the government recommended just a reference to a future pension law in the proposed amendments to the CS bill and introducing mandatory retirement only after the pension law came into effect (PO Letter, 2006). Aneesa Ahmed, MP and a senior government official at that time said:

We should ensure that someone who has served the people for most of their life must be made to retire only after adequate measures are taken so that the living standard of the person does not fall. In my opinion retiring someone without such measures will be very unfair. (A. Ahmed, 2005, translation)

Removal of the provision for a retirement age was adamantly rejected by the sponsor of the bill. Nazim said:

We should aim to establish a viable social security system so that the retirees receive a good benefit. Due to our current political environment and the reforms underway, I do not believe we should delay the establishment of civil service until such a social security system is formulated. (Nazim, 2005b, translation)

Faced with growing support among the MPs for a maximum retirement age, the government eventually agreed to accommodate it. However, as discussed in the next chapter (section 7.4.3), the government made attempts after the ratification of the CS bill, to delay the retirement of civil servants. 
Table 6.4 summarises the proposed amendments and the final outcome regarding the retirement age.

Table 6.4: Retirement age

\begin{tabular}{|c|c|c|c|}
\hline $\begin{array}{c}\text { Original proposal in } \\
\text { the bill }\end{array}$ & $\begin{array}{c}\text { Changes proposed } \\
\text { by the PO }\end{array}$ & $\begin{array}{c}\text { Changes made by the } \\
\text { committee }\end{array}$ & Final outcome \\
\hline $\begin{array}{l}\text { Set the voluntary } \\
\text { retirement age at } 55 \\
\text { years and mandatory } \\
\text { retirement age at } 65 \\
\text { years. }\end{array}$ & $\begin{array}{l}\text { Remove reference to } \\
\text { a specific retirement } \\
\text { age. } \\
\text { reference } \\
\text { retirement in a } \\
\text { proposed pension } \\
\text { law. }\end{array}$ & $\begin{array}{l}\text { Reject the proposal } \\
\text { of the PO and retain } \\
\text { the original } \\
\text { arrangements in the } \\
\text { bill. }\end{array}$ & $\begin{array}{l}\text { As proposed in the } \\
\text { bill. }\end{array}$ \\
\hline
\end{tabular}

\subsubsection{Political participation.}

As discussed in Chapter Two (section 2.3.15), determining the exact extent of political participation of civil servants is a contentious issue. In the Maldives, government was often accused of using government employees for political gains (see section 6.5). Some government employees were also accused of being politically active. In such an environment, calls to establish a CS independent of political influences were widely welcomed and the policy makers opted to restrict political participation of civil servants with the aim of establishing a politically neutral CS.

Initially, the CS bill was silent regarding political participation of civil servants. However, the PO suggested adding an article to the Act to designate a group of civil servants to be determined by the CSC to be restricted from political participation (PO Letter, 2006). The committee amended it to state that all civil servants should refrain from all political participation, probably because MPs believed that this was necessary for a politically neutral CS. No further amendment to the article was submitted from the parliament floor. As a result, it passed unopposed and uncontested. However, to strengthen the definition of "political activities" in article 97 of the bill (see section 6.8.11), Hassan Afeef, submitted an amendment that would 
have barred civil servants from membership of political parties. This amendment failed during the voting on March 27, 2007. Nevertheless, the Act specifically stated that "no employee of the Maldivian Civil Service shall participate in any political activity" (Article 53). These restrictions were broadly supported by the opposition who frequently accused government employees of political activism.

The ramification of this article was felt as soon as the CSC was established and especially after the 2008 constitution was ratified. Legal challenges on the complete ban on civil servants' participation in political activities were mounted as some viewed as it as restricting their civil rights. These issues are further discussed in Chapter Seven (section 7.3.1) where the interactions between the CS model and democratisation are examined.

Another issue addressed was the provision for civil servants standing for political office. The bill stated that any civil servant standing for political office had to resign three months prior to election date. However, the PO suggested changing this to three months leave before the election date. The justification given was that not all candidates standing for political office would do so successfully and so it would be more appropriate to apply for special leave rather than to resign (PO Letter, 2006). Rather than relaxing the provision, the committee chose to tighten it by stating that candidates should resign six months before an election. This latter proposal eventually got passed. However, as discussed in the next chapter (section 7.4.3), once again, amendments were proposed later to relax this provision.

Table 6.5 summarises the proposed amendments and the final outcome in the bill in regard to political participation. 
Table 6.5: Political participation

\begin{tabular}{|c|c|c|c|c|}
\hline $\begin{array}{c}\text { Original } \\
\text { proposal in the } \\
\text { bill }\end{array}$ & $\begin{array}{c}\text { Changes } \\
\text { proposed by the } \\
\text { PO }\end{array}$ & $\begin{array}{c}\text { Changes made } \\
\text { by the } \\
\text { committee }\end{array}$ & $\begin{array}{c}\text { Proposals } \\
\text { during the } \\
\text { second reading }\end{array}$ & Final outcome \\
\hline $\begin{array}{l}\text { No specific } \\
\text { reference to } \\
\text { political } \\
\text { participation of } \\
\text { civil servants. } \\
\text { However, CS } \\
\text { candidates for } \\
\text { political office } \\
\text { to resign three } \\
\text { months before } \\
\text { election date. }\end{array}$ & $\begin{array}{l}\text { Designate a } \\
\text { group of civil } \\
\text { servants to be } \\
\text { determined by } \\
\text { the CSC to be } \\
\text { restricted from } \\
\text { political } \\
\text { participation. } \\
\text { Candidates for } \\
\text { political office } \\
\text { to apply for a } \\
\text { leave of three } \\
\text { months before } \\
\text { election date. }\end{array}$ & $\begin{array}{l}\text { Widen the PO } \\
\text { proposal so that } \\
\text { all civil servants } \\
\text { should refrain } \\
\text { from all political } \\
\text { participation. } \\
\text { Candidates for } \\
\text { political office } \\
\text { to resign six } \\
\text { months before } \\
\text { election date. }\end{array}$ & $\begin{array}{l}\text { Restrict civil } \\
\text { servants from } \\
\text { membership in } \\
\text { political parties. }\end{array}$ & $\begin{array}{l}\text { All civil } \\
\text { servants should } \\
\text { refrain from all } \\
\text { political } \\
\text { activities. No } \\
\text { restriction on } \\
\text { membership in } \\
\text { political } \\
\text { parties. } \\
\text { Candidates for } \\
\text { political office } \\
\text { to resign six } \\
\text { months before } \\
\text { election date. }\end{array}$ \\
\hline
\end{tabular}

\subsubsection{Appointment of permanent secretary.}

The highest ranked civil servant often acts as the link between the political masters and the CS at the organisation level. In some countries the highest ranked civil servant is called the Permanent Secretary (PS). The relationship between the PS and the political appointees can be crucial for effective organisational functioning. For such a relationship to be established and maintained, in some countries, the minister has a say in appointing the PS.

This provision was also initially made in the Maldivian CS bill. According to article 59(a), permanent secretaries should be appointed by the CSC after consultation with the minister responsible for the ministry. However, the PO asserted that a requirement to consult contradicts the de-politicisation efforts of CS and would run counter to the principle of depoliticising the CS (PO Letter, 2006). As the PO's proposed amendment was consistent with the objectives of MPs - particularly those 
of the opposition - to reduce political control of the CS as much as possible, the committee accepted it.

Table 6.6 summarises the proposed amendments and the final outcome regarding the appointment of PS.

Table 6.6: Appointment of permanent secretary

\begin{tabular}{|l|l|l|l|}
\hline $\begin{array}{l}\text { Original proposal in } \\
\text { the bill }\end{array}$ & $\begin{array}{c}\text { Changes proposed } \\
\text { by the PO }\end{array}$ & $\begin{array}{l}\text { Changes made by the } \\
\text { committee }\end{array}$ & \multicolumn{1}{|c|}{ Final outcome } \\
\hline $\begin{array}{l}\text { Appoint PS after } \\
\text { consultation with the } \\
\text { minister. }\end{array}$ & $\begin{array}{l}\text { Remove provision } \\
\text { for consultation with } \\
\text { the minister }\end{array}$ & $\begin{array}{l}\text { Accepted changes } \\
\text { proposed by the PO. }\end{array}$ & $\begin{array}{l}\text { PS to be appointed } \\
\text { by the CSC. }\end{array}$ \\
\hline
\end{tabular}

\subsubsection{Senior executive service.}

As mentioned in Chapter Two (section 2.3.9), a distinct category of the CS can be a senior CS or a senior executive service (SES). Such a category often involves "an elite, professionalized, service-wide corps" (Nunberg, 1992, p. 26).

Establishment of a SES, a new concept for the Maldives, was also initially included in the Maldivian CS bill. The intention was to create a service that was able to: provide professional expertise; provide management and policy advice; foster coordination among government offices; and be exemplary in following the code of conduct (Civil Service Bill, 2005). The framers of the bill probably envisaged a highly professional group of senior civil servants that could be used across the CS to instill a greater work ethic and professionalism on the entire CS. However, probably contrary to the concept of creating a "super-class" that would have extra privileges and benefits, the SES was to be part of the CS and subject to the same rules as other civil servants.

${ }^{95}$ As mentioned in the next chapter (section 7.4.3), the PO later suggested reversing this recommendation thereby including a say by political head of the organisation while appointing the PS. 
Due to the concerns ${ }^{96}$ raised by the PSD that there could be relatively few personnel qualified for an SES, the entire concept was removed from the bill during the committee stage (Nazim, 2006). Removal of these provisions from the bill did not raise any concerns in the majlis. These changes meant that there would be one unified CS in the Maldives.

Table 6.7 summarises the proposed amendments and the final outcome regarding SES.

Table 6.7: Senior executive service

\begin{tabular}{|l|l|l|}
\hline Original proposal in the bill & $\begin{array}{l}\text { Changes made by the } \\
\text { committee }\end{array}$ & Final outcome \\
\hline $\begin{array}{l}\text { Establish a SES to provide professional } \\
\text { expertise; provide management and policy } \\
\text { advice; foster co-ordination among government } \\
\text { offices; and be exemplary in following the code } \\
\text { of conduct. Head of overseas missions to be } \\
\text { chosen from SES. }\end{array}$ & $\begin{array}{l}\text { Remove the entire } \\
\text { concept of SES. }\end{array}$ & \\
\hline
\end{tabular}

\subsubsection{Public service minister.}

A minister responsible for the CS can also be an important aspect in linking the CS to the political executive. An entire chapter in the Maldivian CS bill was dedicated to outlining the responsibilities of the public service minister, including advising the CSC on the implementation of the Act. As mentioned previously (section 6.4.6), the view held by most MPs was to limit political control over the CS as much as possible. Abdullah Shahid, MP and a senior government official at that time, said, "I wonder if the authority of the commission could be diminished if we have a minister and a chairperson of the commission. So we should prevent any contradictions" (Shahid, 2005, translation). The appointment of a cabinet minister responsible for the CS was, therefore, seen as a possible route whereby the president could exert authority to politicise the CS. As a result, to ensure the integrity of the commission

\footnotetext{
${ }^{96}$ The PSD did not raise this issue in writing. It is believed such concerns were raised informally.
} 
the entire chapter on the public service minister and any reference to the minister in the bill was removed by the committee (Shareef, 2006).

Table 6.8 summarises the proposed amendments and the final outcome on the provision for a public service minister.

Table 6.8: Public service minister

\begin{tabular}{|l|l|l|}
\hline \multicolumn{1}{|c|}{ Original proposal in the bill } & $\begin{array}{l}\text { Changes made by the } \\
\text { committee }\end{array}$ & \multicolumn{1}{|c|}{ Final outcome } \\
\hline $\begin{array}{l}\text { Provision of a public service minister } \\
\text { to advise the CSC in the } \\
\text { implementation of the Act. }\end{array}$ & $\begin{array}{l}\text { Remove the entire } \\
\text { chapter. }\end{array}$ & $\begin{array}{l}\text { No provision for a minister } \\
\text { responsible for the CS. }\end{array}$ \\
\hline
\end{tabular}

\subsubsection{Civil service tribunal.}

A mechanism where decisions regarding civil servants can legally be challenged can be important for natural justice. The Maldivian CS bill made provision for a CS tribunal. The bill contained the composition of the tribunal, appointment/dismissal procedures for its members and its authority.

On July 13, 2006, while the CS bill was in the parliamentary committee, the government submitted an employment bill ${ }^{97}$ to the parliament. The employment bill contained a similar provision of an employment tribunal. Since the employment bill covered both public and private sector employment, the committee decided to scrap the CS tribunal as the employment tribunal could cater for all employment grievances (Nazim, 2006). The committee also felt that having two separate tribunals may lead to different criteria in judgments between civil servants or other workers (Shareef, 2006). Having a single tribunal was also believed to be a cheaper option. The grievance management process is discussed later in this chapter (section 6.8.14) where the Maldivian CS model is discussed.

\footnotetext{
97 The bill passed and was ratified on May 26, 2008. Civil Service Act predates the Employment Act. The Employment Act covered both the private and the public sector. Civil service also came under the jurisdiction of the Employment Act. The only exclusion from the Employment Act was the police, armed forces, and any other organisation exempted by another statute (Provisions of the Employment Act that relates to the CS is presented in section 6.8.2- material scope of CS).
} 
Table 6.9 summarises the proposed amendments and the final outcome regarding the CS tribunal.

Table 6.9: Civil service tribunal

\begin{tabular}{|l|l|l|}
\hline \multicolumn{1}{|c|}{ Original proposal in the bill } & $\begin{array}{l}\text { Changes made by the } \\
\text { committee }\end{array}$ & \multicolumn{1}{|c|}{ Final outcome } \\
\hline $\begin{array}{l}\text { Provision for a quasi-judiciary } \\
\text { tribunal appointed by the president. } \\
\text { Decisions of the tribunal could be } \\
\text { appealed at the High Court. }\end{array}$ & $\begin{array}{l}\text { Remove the entire } \\
\text { chapter due to the } \\
\text { provision of an } \\
\text { employment tribunal } \\
\text { in the employment } \\
\text { bill. }\end{array}$ & $\begin{array}{l}\text { No provision for a separate } \\
\text { tribunal for the CS. } \\
\text { Provisions for civil servants } \\
\text { employment tribunal if they } \\
\text { are dissatisfied with the } \\
\text { decision of the CSC. }\end{array}$ \\
\hline
\end{tabular}

\subsubsection{Transition period.}

The Maldivian CS bill had a provision of six months as a transition period (Civil Service Bill, 2005, Article 92a). This period was intended to provide the CSC adequate time to complete implementation of all aspects of the statutory CS. The PO proposed increasing the transition period to three years because the Act would bring fundamental changes to the personnel functions and six months would be too short for all the aspects of the Act to be implemented (PO Letter, 2006). However, considering the volatile political environment at the time and possible opposition to such an extended transition period, as a compromise the committee recommended a one year transition period. Opposition MPs expressed their disappointment in what they perceived as the government's attempt to delay the formation of the statutory CS. An amendment proposed by Ahmed Hamza, MP from Nilandhe Atoll Uthuruburi, to reduce the transition period from one year to six months failed during the voting held on March 27, 2007. Regardless of such setbacks, opposition MPs urged the government not to delay formation of the CS by using the full transition period. Ultimately the bill passed with a one year transition period effective from the date of ratification of the bill. 
Table 6.10 summarises the proposed amendments and the final outcome regarding the transition period.

Table 6.10: Transition period

\begin{tabular}{|c|c|c|c|c|}
\hline $\begin{array}{c}\text { Original } \\
\text { proposal in the } \\
\text { bill }\end{array}$ & $\begin{array}{c}\text { Changes } \\
\text { proposed by } \\
\text { the PO }\end{array}$ & $\begin{array}{c}\text { Changes made } \\
\text { by the } \\
\text { committee }\end{array}$ & $\begin{array}{l}\text { Proposals during } \\
\text { the second } \\
\text { reading }\end{array}$ & Final outcome \\
\hline $\begin{array}{l}\text { Maximum of } \\
\text { six months to } \\
\text { implement all } \\
\text { aspects of the } \\
\text { bill. }\end{array}$ & $\begin{array}{l}\text { Extend six } \\
\text { month period } \\
\text { to three years. }\end{array}$ & $\begin{array}{l}\text { Set one year for } \\
\text { implementation } \\
\text { of all aspects of } \\
\text { the bill. }\end{array}$ & $\begin{array}{l}\text { Change } \\
\text { committee } \\
\text { recommendation } \\
\text { to original period } \\
\text { mentioned in the } \\
\text { bill. }\end{array}$ & $\begin{array}{l}\text { One year set for } \\
\text { implementation } \\
\text { of all aspects of } \\
\text { the Act. }\end{array}$ \\
\hline
\end{tabular}

\subsection{Opposition support for the bill}

Opposition MPs openly welcomed the CS bill (Maldives parliamentary debates, 2005). Though they did not have a majority in the majlis, they pushed for the bill to pass speedily through the parliamentary stage. There were two widely stated arguments by the opposition MPs in support of the bill:

1. President Gayoom was allegedly using government employees to consolidate his powers, most visibly in the islands. Therefore, the CS should be given autonomy from the political executive in matters of employment for an opposition party to have a fair opportunity to win elections.

2. A neutral and competent CS was needed, which would implement the policies of the government of the day.

The latter is a classic argument for having a CS as an independent institution, which is an implicit bargain between different political factions each of which assumes that it will spend time both in and out of the government. However, some argued that, because democratic reforms were in their infant stages during the time of this bill, the opposition was supporting the bill not on some basic philosophy of governance, but simply to curtail any authority of the incumbent president. 
The main opposition party during the period of the CS bill, MDP, won the first democratic presidential election in 2008 and came to power. In arguing that MDP pushed the CS bill simply to curtail the powers of the then President Gayoom, one interviewee pointed out, "the current government ${ }^{98}$ never ever thought they would be able to come into power. They wanted to make things difficult for the government of that time" (Interviewee FO11). Evidently, parliamentary discussions and the amendments proposed to the CS bill by MPs aligned with MDP focused mainly on widening the scope of the CS and limiting presidential powers rather than the overall framework of the CS bill. Furthermore, the opposition also made compromises on some aspects of the bill and they were in general satisfied with the final outcome as it removed a large number of government employees from the direct authority of the government (Interviewee PL2).

\subsection{Government support for the bill}

Apart from tax related bills which can be submitted only by the government, MPs had the authority to submit any bill to the majlis. Government support was not a necessary for such bills to be debated or to proceed to a committee. However, since the CS bill was a public bill, support of the government was a necessity, at least for implementation. While the entire governance structure was under review with constitutional reform progressing since 2004, the government was hesitant to publicly object to the CS bill. As mentioned previously (section 6.2), the bill was submitted and sponsored by two senior officials from the ruling elite. Consequently, government decided to support the bill in the parliament (Interviewees FO4, FO6) as there were much bigger challenges ahead for the government than this piece of legislation (Interviewee PL2). Due to the general support for the bill, the government's support followed despite strong reservations from a number of longserving members of the government (Interviewee FO2) and it was not believed to be a willing decision (Interviewee FO3).

Some even argued that the input from the PO, which was the custodian of government employees at the time, was inadequate and untimely (Interviewees FO3,

\footnotetext{
${ }^{98}$ In reference to the government of President Nasheed.
} 
FO4, FO9). As noted previously (section 6.3), the PO submitted written comments at a very late stage during the parliamentary process. Although the PO attended a number of committee meetings at the request of the majlis, the PO were often accused of not participating adequately in bringing the appropriate changes and not sharing its technical expertise sufficiently (Interviewee FO9).

Such a distancing attitude from the PO was believed to be the result of a degree of resentment or reservation within a group of senior politicians. According to one senior official, "government ... never wanted a [statutory] civil service in this country" (Interviewee FO4). Some even accused a number of senior politicians at the PO of obstructing the bill for fear of losing the grip on state employees (Interviewees FO9, PL2). Regardless of the opposition from some government MPs and senior government politicians, government instructed MPs aligned with the government to vote in favour of the bill to show government's genuine support for political and governance reform. As one interviewee stated "when they accepted this, it wasn't with wholehearted agreement. It was like taking a bitter medicine. They just swallowed it" (Interviewee FO2, Aminath Nihan Translation).

\subsection{Passing of the civil service bill}

MPs aligned with the opposition and those aligned with the government may thus have had different reasons for supporting the CS bill. In any event, open objection to the CS bill was absent in the parliament. An increasing number of MPs considered it as one necessary piece of legislation in the democratisation process. Along with the constitutional amendments underway during that period, a growing consensus appeared to push this legislation through without delay after the committee had submitted its report. However, little attention was given by the MPs to the scale of the changes that were to follow. Constitutional amendments took precedence to the specific details in the CS bill. According to a senior government official "they probably didn't look at this in depth. There were probably very few MPs that were really concerned about what was going to come out of this bill" (Interviewee GO5). The task of constitutional amendments was the dominant agenda for most MPs and although CS reform was one component of the democratic agenda, the CS bill 
appears to have not been given the attention it deserved which had consequences later on (see section 7.4).

Voting for the proposed amendments to the CS bill proceeded on March 27, 2007. As shown earlier (section 6.4), all significant changes were made during the committee stage. A total of 55 amendments were proposed during the second reading of the bill. The majority of the proposed changes were editorial which did not have a significant bearing on the model of the CS. A total of 31 amendments passed.

After about two and half years in the parliament, voting on the entire CS bill was held on April 4, 2007. In the deliberations prior to the voting, most MPs reiterated the importance of amendments that would be needed later on, but also the importance of passing it at that stage despite some possible gaps in its provisions. The main issue was regarding the compatibility of the bill with the form of government $^{99}$ - either parliamentary or presidential - to be decided when the constitution was amended, a process that was not completed until August 2008. As a result, the CS Act came into existence under the 1998 constitution, which accorded the executive powers that would be significantly abridged by the 2008 constitution. The main challenges that rose as a result of this are discussed in Chapter Seven (section 7.2). Regardless of concerns raised by some MPs on the final outcome of the bill, the 36 MPs present voted unanimously to pass the bill. The president ratified the bill on May 2, 2007.

\subsection{Civil service model of the Maldives}

To assess the Maldivian model, the rules, structures, roles, and norms of the CS are presented by studying the CS Act, the CS regulations, and administrative practices in relation to the attributes or properties of a more general CS model. The discussion follows the general structure presented in sections 2.3.5 to 2.3.19 of Chapter Two where the components of a CS model are presented.

\footnotetext{
${ }^{99}$ As mentioned in Chapter Four (section 4.3.3), a public referendum was held to decide the form of government - presidential or parliamentary - to be enshrined in the new constitution. This vote was held in August 2007. Therefore, at the time of passing the CS bill, it was not clear whether the new constitution would have provision for a president with significant executive powers.
} 


\subsubsection{Legal basis of civil service.}

The Maldivian CS comprises three main tiers of legal provision: constitution; Act; and regulation. As shown in Chapter Four (table 4.3), the CSC was made a constitutional organisation by the 2008 constitution. Reference to the CSC as an "independent and impartial institution" (Article 179b) in the constitution lays the foundation for the CS. A commission independent of the political executive that is assigned full responsibility for management of the CS marks the beginning of a new chapter in the governance of the Maldives. A five member commission which is appointed and reports to the parliament, and the absence of any cabinet portfolio for setting the CS policy, is meant to provide the independence and the impartiality of the CS that the lawmakers demanded. The lack of linkages between the political executive and the CSC has at times been the source of friction, some of which is examined in the next chapter (see section 7.2.1).

The main responsibilities and powers of the CSC are also specified in the constitution. On the one hand this ensures orderliness, but on the other hand it hinders flexibility. The constitution grants the CSC powers of personnel management for the CS, formulation of rules and regulations for the CS, and sets out the general reporting mechanism for the CSC. The procedures for appointment, dismissal, and resignation of commissioners, their qualifications, and their term limits are also specified in the constitution. As noted earlier (section 6.4.3), the only contradictory aspect in the Act in relation to the constitution is the imposition of a maximum limit of two terms for the commissioners in the constitution, whereas the Act provides the provision for renewal every five years without a term limit.

The CS Act provides the second tier of legal basis and covers aspects such as definition of the CS, general guidelines for civil servants, detailed powers and responsibilities of the CSC, duties of permanent secretaries and the CS advisory committee that advises the government on matters relating to management of the CS. The Act has been amended twice since its passage in 2007, although other amendments have been proposed (see section 7.4.3). Out of these, the only comprehensive amendment proposed to the Act has been by the CSC itself, which the parliament has so far not debated. 
The CS regulation provides extensive detail on different issues. The CSC has authority to formulate and revise regulations. Presently, the Maldives Civil Service Regulation (MCSR) 2010 is in effect (CSC, 2010a). Periodic revisions are undertaken and thus it has expanded from 19 chapters in March ${ }^{100} 2008$ to 32 chapters by February 2012 (also see section 7.4.1). Some of the most important aspects in the regulations are examined in the following sections.

\subsubsection{Scope of civil service.}

This section examines the scope of the Maldivian CS and its implications.

Vertical scope - Permanent secretaries are the highest ranked civil servants in the government ministries of the Maldives. However, outside the purview of the CS Act, the constitution grants the president powers to appoint any number of political staff into the ministerial hierarchy. Such provision provides virtually unlimited powers that could be used for patronage appointments. ${ }^{101}$ Although these powers have mostly been used to appoint state ministers, deputy ministers, and advisers to the ministers, lower level positions that undertake civil servants' tasks have also been filled occasionally by politically appointed staff (for example appointment of a senior project director to the Ministry of Housing and Environment, a post equivalent to director general on the CS hierarchy). ${ }^{102}$

For organisations other than ministries, the highest ranked civil servant is the responsible officer (performing duties similar to a PS) who is appointed by the CSC. Even for such organisations, the president can make any number of political appointments. For the elected city, atoll, and island councils too, the CSC appoints a responsible officer who is the highest ranked civil servant in the councils. ${ }^{103}$

\footnotetext{
${ }^{100}$ The first CS regulation was published in March 2008 in preparation for the launching of CS in May 2008.

101 The extent to which this power has been used is discussed in section 7.3.3.

${ }^{102}$ More examples of such appointments are given in section 7.3.3.

${ }^{103}$ Controversy surrounding the appointment of responsible officers is discussed in section 7.2.1.
} 
As mentioned above, the past few years of the statutory CS has shown that lower level positions that undertake civil servants' tasks have also been filled occasionally by politically appointed staff. However, as there have been few such appointments, it is too early to conclude that they are evidence of an attempt to create a parallel political administration. These appointments seem more likely to be an attempt to keep certain individuals within the public sector, based on their capabilities rather than their political affiliation, by offering greater benefits than those offered by the CS. As a result, it is safe to assume that the vertical scope of the CS has been relatively intact so far.

Horizontal scope - The CS Act sets the horizontal boundary of the Maldivian CS by listing the organisations and designations that are not part of the CS. Armed forces personnel and employees of state owned enterprises (SOEs) are specifically excluded. The CS Act also allows for any organisation or designation to be excluded from the CS through other legislation. Since the CS Act came into existence, this provision has been used widely to significantly narrow the scope of the CS. Organisations such as the police and the entire judicial sector which are significant employers were both excluded under the governance reform of 2008. The university and customs service, both also with considerable staff, along with several other smaller organisations have followed suit (tables 6.11 and 6.12 list organisations included and excluded from the CS by the end of 2011).

Table 6.11: Organisations included in the civil service

\begin{tabular}{|l|}
\hline \multicolumn{1}{|c|}{ Organisations included in the CS } \\
\hline Ministries \\
\hline Attorney General's Office \\
\hline Departments and offices responsible to a ministry \\
\hline City councils, atoll councils, island councils \\
\hline High commissions, embassies, overseas missions $^{104}$ \\
\hline Maldives Media Council $^{105}$ \\
\hline National Archives $^{106}$ \\
\hline
\end{tabular}

\footnotetext{
104 The most senior posts in the missions are appointed by the president.

${ }^{105}$ Media council is a statutory body with elected members. The staff of the council belong to the CS.
} 


\begin{tabular}{|l|}
\hline National Social Protection Agency $^{107}$ \\
\hline National Plant Protection Organisation $^{108}$ \\
\hline Dhivehi Language Academy $^{109}$ \\
\hline Hospitals (those not corporatised) $^{110}$ \\
\hline Schools $^{110}$ \\
\hline
\end{tabular}

Table 6.12: Organisations excluded from the civil service

\begin{tabular}{|l|}
\hline \multicolumn{1}{|c|}{ Organisations outside the CS } \\
\hline Judiciary \\
\hline People's Majlis \\
\hline President's Office \\
\hline Maldives National Defence Force \\
\hline Maldives Police Service \\
\hline State owned enterprises \\
\hline Hospitals (those corporatised) \\
\hline Human Rights Commission of the Maldives \\
\hline Capital Market Development Authority \\
\hline Maldives Monetary Authority \\
\hline Auditor General's Office \\
\hline Judicial Service Commission \\
\hline Police Integrity Commission \\
\hline Civil Service Commission \\
\hline Prosecutor General's Office \\
\hline Elections Commission \\
\hline Anti-Corruption Commission \\
\hline Labour Tribunal \\
\hline Maldives Pension Administration Office \\
\hline Maldives Inland Revenue Authority \\
\hline
\end{tabular}

\footnotetext{
${ }^{106}$ National Archives is a statutory body. Except for the director general who is appointed by the president, all staff belong to the CS.

${ }^{107}$ NSPA is a statutory body in charge of health insurance. The chief executive officer is appointed by the president. Other staff belong to the CS.

${ }^{108}$ NPPO is a statutory body. The minister chooses the head of the organisation and phytosanitary inspectors in accordance with the CS Act.

${ }^{109}$ Five members of this statutory organisation are appointed by the president. The staff of the academy are civil servants.

${ }^{110}$ A few public schools were privatised by Nasheed's government.
} 


\begin{tabular}{|l|}
\hline Tax Appeal Tribunal \\
\hline The Maldives National University \\
\hline Local Government Authority \\
\hline Maldives Broadcasting Commission \\
\hline Maldives Civil Aviation Authority \\
\hline Maldives Customs Service \\
\hline
\end{tabular}

One of the controversial approaches used by the government to redefine the horizontal scope of the CS has been to corporatise government organisations. While 15 SOEs existed at the end of 2008 (MOFT, 2009, p. 6), there were 65 at the end of 2011 (MOFT, 2011). Most of the newly established SOEs were previously government organisations. As a result of their corporatisation there has been a significant reduction in the number of civil servants. The biggest sector that has been corporatised so far is the government hospitals, which previously comprised entirely civil servants. A number of government schools have also seen such a move. The changes in the horizontal scope of the CS have meant that the number of civil servants has significantly declined from 2008 to 2011 (see figure 6.1). Chapter Seven (section 7.3) further examines the impact of politicisation of the CS.

Figure 6.1: Civil servants versus staff moved out of civil service (2008-2011)

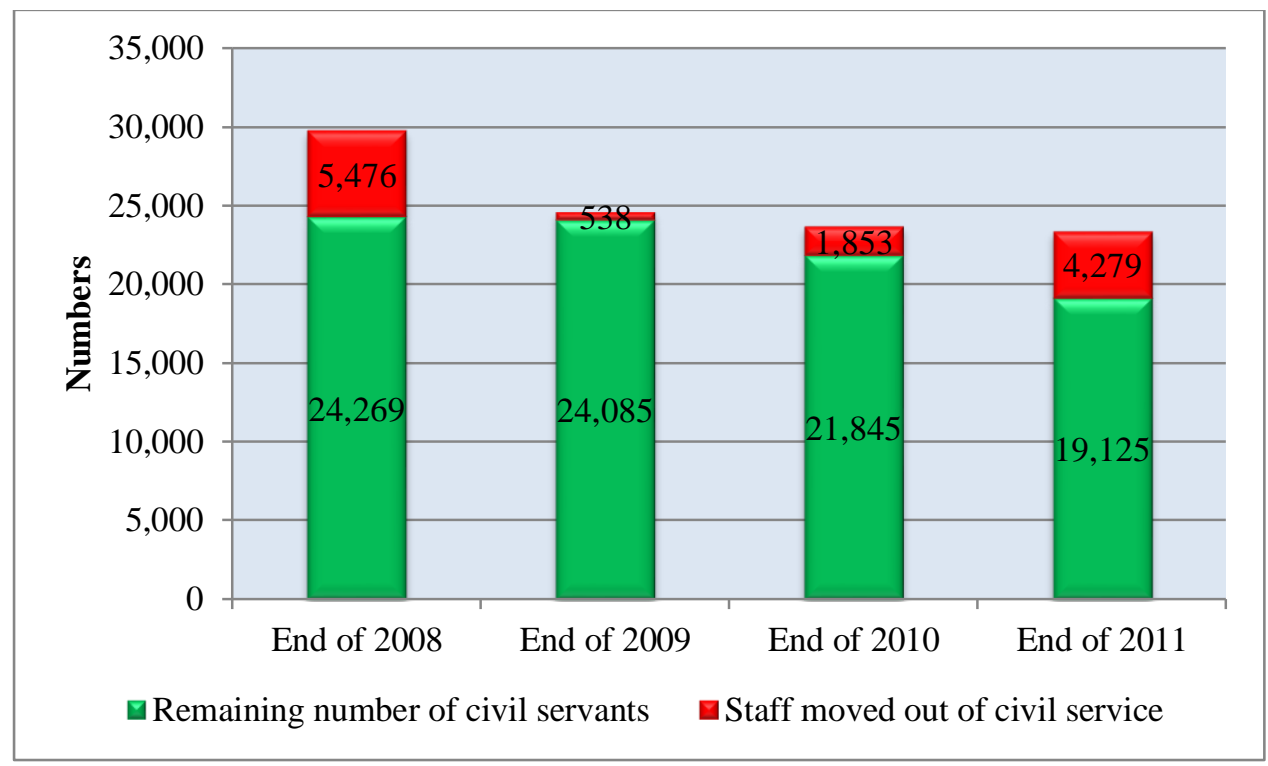

Source: CSC (personal communication, March 21, 2012; August 27, 2012) ${ }^{111}$; DNP (2010, 2011)

111 The data provided by CSC for the year 2008 is revised here. Schools and hospitals are excluded
because the staff excluded from CS are mostly expatriate workers, all of whom were handed contracts 
Material scope ${ }^{112}$ - Other Acts besides the CS Act affect the material scope of the Maldivian CS. The two most important Acts are the Employment Act (No. 2/2008) and the Pension Act (No. 8/2009). The Employment Act covers all the general principles of employment to which the CS also must adhere. The general principles covered in the Employment Act include: basic rights of workers; restrictions on employment of minors; guidelines for employment contracts; principles of work ethics; procedures for disciplinary measures and dismissal; limit of working hours; entitlements on leave; guidelines on remuneration and basic wage; and occupational health and safety. Although a statutory CS was in place when the Employment Act was passed, the lawmakers opted for CS to follow the Employment Act with detailed $\mathrm{CS}$ regulations to be in line with the general employment guidelines. ${ }^{113}$

As it is mandatory for all public and private sector workers to enter the statutory pension scheme, civil servants also contribute to the scheme. Other legislation that affects the CS covers aspects such as presidential powers on setting the mandate of government organisations and general responsibilities of government employees (Official Kanthah [Issues] Chapter 1 (law no. 1/68)), procedures for writing official letters and reports (Official Kanthah [Issues] Chapter 2 (law no. 2/68)), service bonds for receiving government funded education (Service Bond for Government Funded Education Act (No. 29/76)), and general guidelines for the language used in official documents (National Language (priority) Act (law no. 9/2011)).

Since the establishment of the statutory CS, no serious concerns have been raised regarding its material scope. However, some changes may be needed to align with the present day legal framework. For instance, the Acts of 1968 mentioned above are in need of amendments to ensure a high degree of accountability of state officials. In

from the inception of CS in May 2008. Furthermore, organisations such as the Defence Force, SOEs, Auditor General's Office, Human Rights Commission of the Maldives, Capital Market Development Authority, Maldives Monetary Authority, and Parliament Secretariat are also excluded because the staff in those organisations were not considered civil servants at the inception of CS. Additionally, the total number of civil servants for the years 2009 and 2010 is derived from the Statistical Yearbooks. A breakdown of the number of civil servants moved out of CS is given in the next chapter (Tables 7.3 and 7.4).

${ }^{112}$ As stated in section 2.3.6, material scope is concerned with aspects of the CS employment such as pensions, working hours or holidays that can be regulated by more general labour laws.

${ }^{113}$ Recently, the Attorney General of the Maldives cited a number of inconsistencies between the Employment Act and the newly revised Civil Service Regulation of June 2012, a regulation formulated under the CS Act (Attorney General's Office, 2012). 
addition to that, minor inconsistencies exist between the CS Act and Employment Act (Interviewees GO1, GO5, GO6). Such issues are mainly because the CS Act predates the Employment Act and the CS had to realign its regulations after the Employment Act came into effect.

\subsubsection{Management of civil service.}

Management of the CS is linked to the responsibilities of the state as the employer of civil servants. In the case of the Maldives, in the absence of a central ministry, the CSC centrally manages the entire CS. The main functions carried out by the commission include: 1) formulating regulations on personnel management functions of the CS (for example appointment, dismissal, transfer, setting benefits, grievance, discipline); 2) managing the personnel management function (for example approval of appointments and dismissals); and 3) investigation of grievances and sanctioning of civil servants. Additional responsibilities of the commission include formulating a code of conduct, setting the classification system for the entire CS and approving the organisational structure for all CS organisations - creating the need for reconciliation of the CS and national budget. ${ }^{114}$ Such extensive authority is meant to ensure uniformity across the Maldivian CS.

The CSC delegates limited authority on employment processes to the ministries and organisations. As discussed in the following sections, the CSC set the rules and guidelines for all processes of personnel management. Written approval is sought from the CSC for all the main functions of personnel management such as appointment, dismissal, or transfer. Individual ministries merely carry out those tasks at the organisational level. At times, this has raised concerns because the centralised procedures that existed prior to the establishment of the CSC have been continued (Interviewee FO6).

\footnotetext{
114 The government formulates organisational mandate. The CSC approves the organisational structure. All the posts in the organisation need to be included in the organisational budget. The MOFT has the right to amend organisational budgets before sending them to the majlis for approval. Once budget is approved, individual organisations can create any new posts specified in the approved budget. Additional approval from the MOFT is not required. However, to create a new post not included in the approved budget, approval from the MOFT is often required.
} 
During the drafting of the bill no discussion took place on introducing a greater degree of decentralisation of the CS management. No radical shift in personnel management was proposed in the Act other than removing the prerogatives of the president and handing it over to a statutory body. As a result, the previous centralised system of management is maintained within the statutory CS. This has a number of implications in the context of an emerging democracy, a topic discussed in the following chapter (sections 7.2.2 and 7.4).

\subsubsection{Code of conduct.}

The first attempt to provide legal status for government officials in the Maldives was by a law in 1968 (see section 5.3). The general responsibilities of government employees were specified in that law. Since then, such principles have been written into the regulations governing government employees - as mentioned earlier (section 5.4.8), a code of conduct for government employees was in place even prior to the statutory CS. Those principles had been evolving over the years. With the formation of the CS, they have been specified in more detail (chapter 2 of MCSR). They are also in line with the general principles of conduct specified in the 2008 constitution (Article 182b).

The Maldives has, arguably, adopted a law-based approach. In this respect, the CS Act specifically states that a code of conduct needs to be devised by the CSC (Article 18f). Therefore, rather than having a code at the level of general principles, the Maldives have opted to cover detailed prescriptions in such secondary legislation (refer to section 6.8.13 for some of the principles outlined in the code of conduct).

\subsubsection{Categories of civil servants.}

A key feature of classical Weberian bureaucracy is having a substantial degree of horizontal coherence across the CS that includes uniform terms and conditions. The Maldivian CS reveals a number of departures from such a classical model.

In broad terms, the Maldivian CS is a unified CS. As mentioned earlier (section 6.4.7), the concept of SES was dropped during the parliamentary debates, based on 
the argument that not enough personnel would qualify for such a core group of civil servants in a small nation such as the Maldives. Nonetheless, the CS Act and the corresponding regulation have provision for four categories of employees: permanent employees, temporary employees, contract employees, and volunteers. Both temporary and contract appointments are exceptions to the classical model of a career CS.

Temporary staff are employed to carry out a project for a specified time period, or to complete a temporary task (Clause 125 of MCSR). In all respects other than their limited tenure, temporary civil servants are subject to the same rules as permanent civil servants. Contract employees can be hired for jobs for which eligible and competent persons are scarce (Clause 134 of MCSR) and upon approval from the CSC can receive additional financial incentives - which is also a departure from the classical model that demands uniformity in remuneration. Unpaid volunteers can also be hired in the case when a qualified person did not apply for the vacant job or as a source of advice and guidance to staff (Clause 139 of MCSR). Volunteers are normally hired for a fixed period through organisations such as Voluntary Service Overseas (VSO).

The Employment Act requires that all workers that come under its jurisdiction should have an employment contract signed between the employee and the employer. This provision applies to all categories of civil servants. Although permanent employees do not have a term limit in their contracts, the contract needs to be in line with the Employment Act and the CS Act. For instance, arbitrary termination is not permitted. Furthermore, in these employment contracts, people are appointed to a particular organisation or position rather than a CS - which is also a departure from the career system where the civil servant is assigned to the CS rather than to a specific organisation.

The Maldivian CS also hires a large number of expatriates on a fixed term, especially for teaching and health professions. They are hired only when qualified locals are not available (Article 41c of the CS Act) and thus do not compete with the locals. 
All these provisions give the CSC significant flexibility in filling the posts through the use of different types of staff, either on a permanent basis, temporary basis, or fixed-term contracts.

\subsubsection{Merit system.}

The classical CS model also features a permanent CS where recruitment and promotion are based on merit rather than by patronage or political affiliation. Until the CS Act, merit had been an alien concept for employment in the Maldivian government. During parliamentary debates, lawmakers argued that in the absence of merit, a wide range of exceptions, especially close to election periods, were evident in appointment, transfer, and promotion of public officials (see section 5.4.5). They opted to give those powers to a statutory body rather than the president and they decided that the best criteria that can be used in personnel management were meritbased. To ensure no discrepancies exist in the application of merit, they chose to carefully define what merit connotes. According to the CS Act, when using merit at all levels of appointments (recruitment and promotion), preference should be given to academic results followed by past experience in the field of work (Article 5e). So far no evidence is available that the CSC has violated the application of merit. Any violation risks legal challenges.

\subsubsection{Recruitment system.}

Recruitment is closely tied with the concept of merit. All recruitments in the Maldivian CS, including appointments to all vacancies at all levels, and positions filled by transfers, require the approval of the CSC. Recruitment practices in the Maldivian CS are inclined towards a more open system model than the closed-entry recruitment system.

Six main features relating to the open system model are of significance. Firstly, lateral entry to any level of the hierarchy was allowed before the statutory CS and remained permissible under the new Act. However, since the private sector normally pays relatively high wages, especially for technical and professional jobs, it is uncommon for private sector workers to join the CS through lateral entry. In most 
cases, staff who have a service bond as a result of state-funded higher education, normally enter the designated job laterally. Secondly, previous work experience in both the public and private sectors can be recognised for appointment. This provision is allowed to encourage movement between public and private sectors. Thirdly, vacant positions are filled by open competition, with internal and external candidates vying for the position. Public advertisements are a requisite for any vacant position regardless of whether an eligible person is available within the organisation. This is basically a continuation of the rules that existed in the pre-civil service period. However, given the nature of the CS conditions, there are rarely external applicants and therefore appointments of internal staff are the norm. ${ }^{115}$

Fourthly, entrance examinations for civil servants have never been used in the Maldivian public sector and currently play no part in appointments to the statutory CS either. However, by early 2012, the CSC was consulting with stakeholders to assess the feasibility of introducing an entrance examination. Fifthly, as mentioned previously (section 6.8.5), short-term contract employment is also permitted. Such provisions are used in fields with a shortage of qualified personnel. Sixthly, a high degree of horizontal mobility from one organisation to another is allowed within the CS (see table 6.13).

Table 6.13: Total number of transfer applications approved by the civil service commission

\begin{tabular}{|l|c|c|c|}
\hline & $\mathbf{2 0 0 9}$ & $\mathbf{2 0 1 0}$ & $\mathbf{2 0 1 1}$ \\
\hline Approved transfers & 1304 & 797 & 2177 \\
\hline
\end{tabular}

Source: CSC (personal communication, August 27, 2012) ${ }^{116}$

Although recruitment practices thus lean towards an open system model, there are a number of features found in the classical model. One already mentioned is the requirement for the CSC to approve all placements including appointments, transfers, and promotions. This centralisation is often cited as a source of delay.

\footnotetext{
${ }^{115}$ Details on applications are maintained by individual organisations. Since such information is not available centrally, statistics on internal/external recruitments are difficult to obtain.

${ }^{116}$ At times, CSC can reject transfer applications. According to the CSC, they do not maintain records of the total transfer applications submitted for approval.
} 
Ministries run their own recruitment processes ${ }^{117}$ but require CSC approval which it can refuse if the merit principle is not upheld. The CSC oversees ministries' recruitment by requiring them to send it the results of all the interviews, both successful and unsuccessful (Schedule 9 of MCSR). A second feature is the use of selective entry requirements. These requirements are pre-defined and formulated centrally by the CSC. The following section on classification system in the Maldivian CS examines these aspects more closely.

Table 6.14 shows the total number of approved applications for appointments (excluding transfers) sent to the CSC for the period 2009-2011.

Table 6.14: Total number of appointment applications approved by the civil service commission

\begin{tabular}{|l|l|l|l|}
\hline & $\mathbf{2 0 0 9}$ & $\mathbf{2 0 1 0}$ & $\mathbf{2 0 1 1}$ \\
\hline Approved applications & 2672 & 4467 & 3577 \\
\hline
\end{tabular}

Source: CSC (personal communication, August 27, 2012)

\subsubsection{Classification system.}

The CSC has developed one unified position classification system for the entire CS. It is a hybrid of closed and open systems containing features of both rank-in-job and rank-in-person classification systems.

Typically for a rank-in-job system, position classification in the Maldivian CS is based on the assumption of equal pay for work of equal value. Jobs of the same nature, duties, responsibilities, and workload are grouped together (Clause 34(b) of MCSR) (refer to figure 6.2 for the administrative structure of designations ${ }^{119}$ ).

\footnotetext{
${ }^{117}$ These practices are similar to those found in many other countries. They include interviewing all the eligible candidates by a panel that does not include any family member or political appointee (Clause 106 of MCSR), and awarding points based on academic qualifications, extent of past work experience, skills needed, and individual competencies (Schedule 8 of MCSR). Unsuccessful candidates are also informed of the outcome (Clause 108 of MCSR). Similar criteria were used for recruitment even before the statutory CS.

118 At times, CSC can reject appointment applications. According to CSC, they do not maintain records of the total appointment applications submitted for approval.

${ }^{119}$ The provisions for increments are discussed later in this section.
} 
Furthermore, each of these organisational groups has a unified salary structure. For instance, all grade six officers, irrespective of the organisation, generally receive the same remuneration. ${ }^{120}$

Figure 6.2: Administrative structure of designations

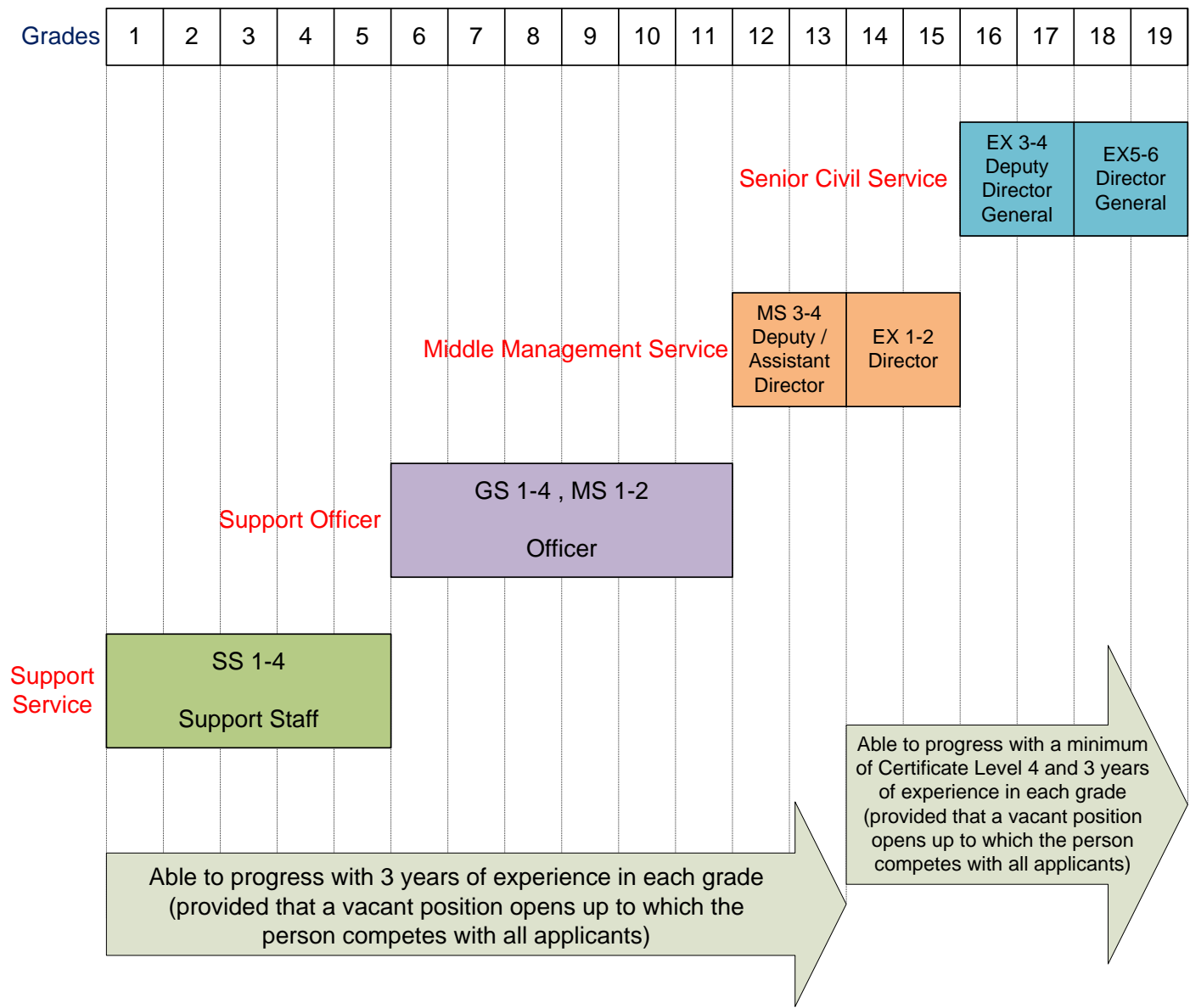

A number of features related to the rank-in-person system are also evident in the Maldivian CS. Firstly, academic qualifications are important at some of the entry points which can be used for lateral entry (for example at grade 14). Secondly, once in the job, the civil servant can progress through the grades, provided that a position becomes vacant and the civil servant meets the job specifications and competes with all applicants to the new position (for example from grade 1 to 13). Thirdly, rather than basing the specification entirely on academic qualifications, work experience (often calculated based on the number of years in service) is also considered an important aspect (for example from grade 14 onwards).

\footnotetext{
${ }^{120}$ An exemption is given to a number of selected professions that are offered higher service allowances and thus their total remuneration can be higher (refer to section 6.8.9).
} 
As evident in most traditional civil services, the classification system is based on providing a salary increment. However, rather than basing it on solely on the length of service, adequate performance is a requirement in the Maldivian CS. The CSC has devised a ten-step salary increment system that operates within each grade, with a fixed increment of MVR200 for each step. The civil servant is eligible for this increment based on the outcome of the performance appraisal system. Although this new system has been in place since 2009, salary increments have not been provided mainly due to the unavailability of funds to cover the costs. One other possible reason could be the inability to effectively institutionalise the appraisal system, making the government reluctant to commit financially as the failure of the performance appraisal in the 1990s is still fresh (see section 5.4.5). Nonetheless, as figure 6.3 shows, appraisal forms are at least completed for the majority of civil servants although it is not possible to conclude that the system achieves its outcomes of accurately assessing or improving individual performance. Furthermore, as shown in table 6.13, horizontal mobility across the CS is quite common in the absence of an automatic promotion system (see section 6.8.10), as civil servants aim to maintain their career progression by moving to other organisations where openings occur.

Figure 6.3: Completion of performance appraisal forms

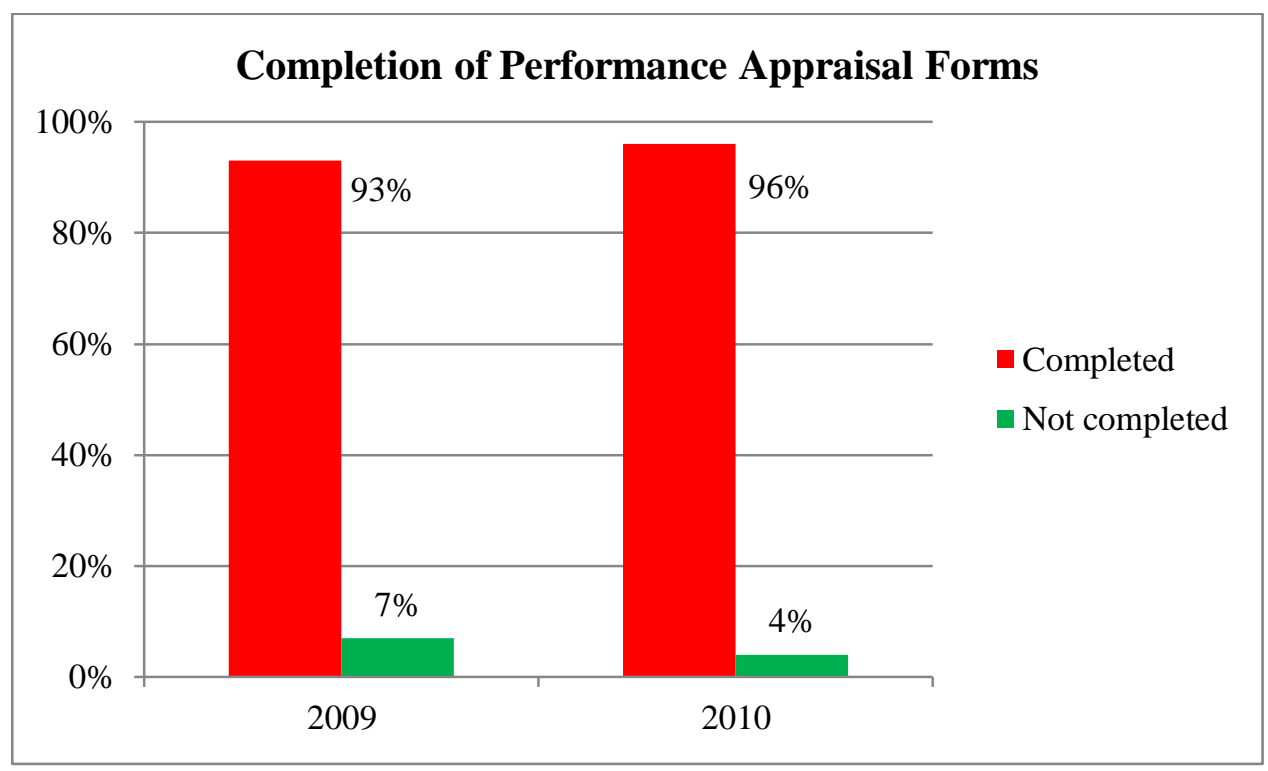

Source: CSC (2011a)

In line with other features of the centralised administration in the Maldives, the classification system is developed and revised by the CSC. All new jobs are required 
to be included in the unified system and approval for any such inclusion needs to be obtained from the CSC (Clause 32(b) and 37 of MCSR). ${ }^{121}$ Another feature evident in the Maldivian CS is the high number of civil servants at the lower grades of the classification system (see table 6.15). Such bottom-heaviness is the long term effect of employment generation that occurred before the formation of the statutory CS (see section 5.4.7).

Table 6.15: Civil servants and their ranks at the end of 2010

\begin{tabular}{|l|c|c|}
\hline Classification & Rank & Number of civil servants \\
\hline Permanent secretary & ZV7 & 16 \\
\hline \multirow{2}{*}{ Senior civil service } & EX 5-6 & 64 \\
\cline { 2 - 3 } & EX 3-4 & 61 \\
\hline $\begin{array}{l}\text { Middle management } \\
\text { service }\end{array}$ & EX 1-2 & 226 \\
\cline { 2 - 3 } Support officer & MS 3-4 & 1339 \\
\cline { 2 - 4 } & MS 1-2 & 5274 \\
\hline Support service & GS 1-4 & $\mathbf{7 8 4 1}$ \\
\hline \multicolumn{1}{|c|}{ TOTAL } & & $\mathbf{7 0 2 4}$ \\
\hline
\end{tabular}

Source: DNP (2011)

\subsubsection{Salary and reward.}

In the traditional career CS model, a statutory remuneration scheme is often developed for civil servants with standard rates for each grade. In models that shift from the classical model, differentiated and/or individual rates of pay are set. Remuneration in the Maldivian CS lies in between these two extremes.

There is no law setting remuneration for civil servants. A uniform salary and reward structure is developed and managed by the CSC. As mentioned in section 6.8.8, permanent civil servants on the same grade generally receive the same benefits irrespective of the organisation. Variation in benefits is allowed only for contract staff (refer to section 6.8.5).

\footnotetext{
${ }^{121}$ Civil servants also have the right to recommend changes to the classification system by submitting proposals to the CSC (Clause 36 of MCSR).
} 
The CS salary and benefits are based on a pre-determined salary and a service allowance (based on the rank in the classification system) combined with a number of general allowances and welfare allowances (based on the organisation and type of work) (CSC, 2009a). Figure 6.4 summarises the salary and benefit structure.

Figure 6.4: Salary and benefit structure

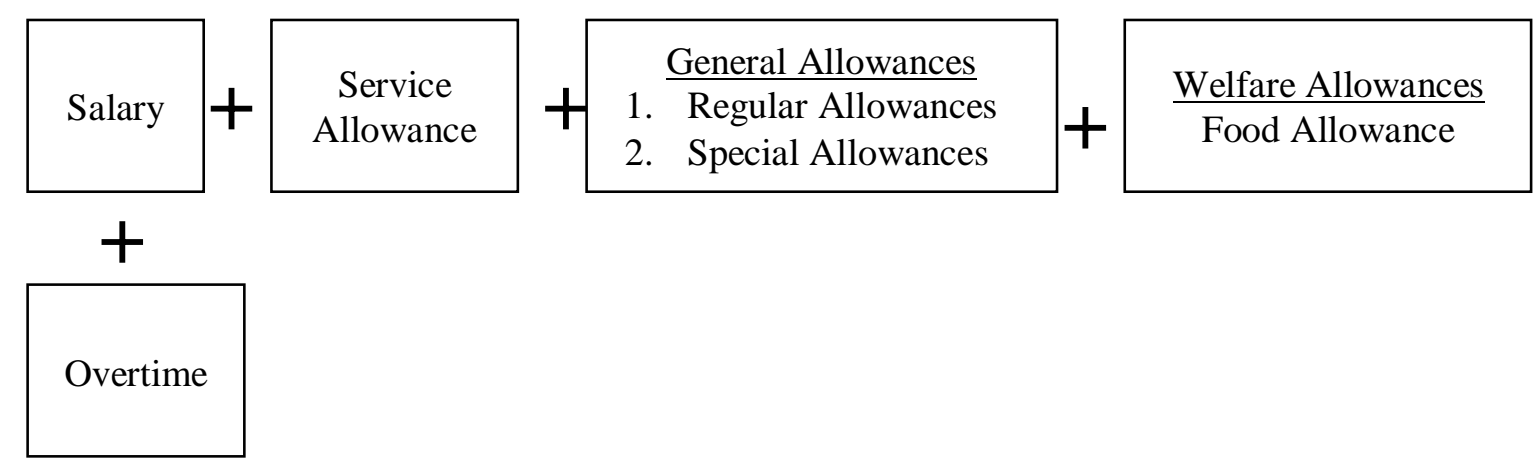

Table 6.16 provides an overview of the pay scales in relation to the classification system. It also shows the salary differences within each rank. As the table shows, the least difference between the ranks is evident in the middle ranks with the highest disparity at the top and the lowest ranks. Furthermore, in a clear deviation from the classical model, higher service allowances are paid to some of the professions which are considered scarce.

As mentioned previously (section 6.8.3), the CSC determines all the allowances and who is entitled to them. On the positive side, having a unified system managed by the commission ensures that the benefits of every position are standard and publicly known. On the negative side, the inflexibility and the continuous authorisation protocols for allowances often create backlogs and delays in management of government organisations. The extent of the centralisation of the rules is evident from Clause 66(a) of MCSR which states "The commission shall determine the employees who shall be given uniforms, the design of the uniform and number of uniforms which shall be provided annually and the amount to be given for stitching of the uniform". Once again, a central and uniform system as far as financial benefits are concerned is one that is inherited by the commission which has decided to maintain the status quo. 
Table 6.16: Pay scale

\begin{tabular}{|l|c|c|c|c|}
\hline Classification & Rank & $\begin{array}{c}\text { Number of } \\
\text { civil } \\
\text { servants }^{122}\end{array}$ & $\begin{array}{c}\text { Monthly salary } \\
\text { range (In MVR) }\end{array}$ & $\begin{array}{c}\text { Inter-rank } \\
\text { salary } \\
\text { difference (In } \\
\text { MVR) }\end{array}$ \\
\hline Permanent secretary & ZV7 & 16 & 35,500 & 1670 \\
\hline \multirow{2}{*}{ Senior civil service } & EX 5-6 & 64 & $14,090-15,760$ & 1335 \\
\cline { 2 - 5 } & EX 3-4 & 61 & $11,265-12,600$ & 1055 \\
\hline Middle management & EX 1-2 & 226 & $9035-10,090$ & 840 \\
\cline { 2 - 5 } service & MS 3-4 & 1339 & $7235-8075$ & 685 \\
\hline \multirow{2}{*}{ Support officer } & MS 1-2 & 5274 & $5810-6495$ & 1455 \\
\cline { 2 - 5 } & GS 1-4 & 7841 & $3765-5220$ & 1240 \\
\hline Support service & SS 1-4 & 7024 & $3300-4540$ & \\
\hline TOTAL & & 21,845 & & \\
\hline
\end{tabular}

Source: CSC (2010b); DNP (2011)

Note: The household income and expenditure survey conducted by the government in 2009/2010 revealed that, at the national level, the average monthly income per earner was MVR6727 (DNP, 2009/2010).

\subsubsection{Promotion system.}

The promotion system in the Maldives reveals features of both career system and position-based systems. Firstly, promotion is based on the principle of merit. According to the regulation, promotions are awarded "to assign a greater responsibility for employees who can prove that the responsibilities of their job has been carried out properly, their level of job performance was good, and the employee has good work ethics" (Clause 97 of MCSR). Secondly, though, regardless of the suitability of an individual employee for promotion, it can proceed only when a vacancy opens up in the organisation for which qualified internal and external candidates can compete. Similar to recruitment, an interview process needs to be followed before a promotion decision.

\footnotetext{
${ }^{122}$ Number of civil servants at the end of 2010 .

${ }^{123}$ Salary is calculated by summing the basic salary and the fixed service allowance. Some of the professions are offered higher service allowances and thus the salary will be higher for them than those given in the table.
} 
The requirements for open competition for promotion and the existence of a vacant position are new since the inception of the statutory CS. Previously, promotion could be recommended by the organisation after considering performance, attendance, and length of service even in the absence of a vacant position.

In line with the centralised nature of administration that existed even before the statutory CS, promotion is confirmed upon approval by the CSC. The salary increment system mentioned previously (section 6.8.8) does not connote a promotion and since the increment system is presently not functional, no performance-based pay is in place. The only current option for a salary increase is promotion to the next grade (refer to figure 6.2).

\subsubsection{Political rights and neutrality.}

A key feature of the classical CS model is the clear separation of functions and responsibilities between civil servants and their political masters. Such separation can be important to maintain the political neutrality of civil servant and a clear separation between public duty and private interest. This demarcation can be blurred in any government but may be more problematic in small societies (see section 5.4.6).

In the absence of the statutory CS, such demarcations were not visible in the Maldives. The framers of the Maldivian CS have chosen to clearly define those lines in the legislation. Civil servants have limitations on their political participation. Article 53 of the CS Act states "No employee of the Maldivian Civil Service shall participate in any political activity". ${ }^{24}$

The importance of defining the extent of political participation is evident from the CS regulations published in 2008 which had an entire chapter focused on outlining

\footnotetext{
124 The definition section of the Act further defines the term "political activities" as: a) Lobbying to garner support for any political person or participating an activity thereof; b) Organising or participating in any political activity against any political person; c) Participating to garner support for or against a candidate competing in an election under the Constitution and the Laws of the Republic of Maldives; and d) Standing to be elected to a political position under the Constitution or the Laws of the Maldives or seeking to be a candidate (Article 77 of the CS Act).
} 
the parameters of political activities. However, as discussed in the next chapter (section 7.3.1), the CSC removed that chapter in face of legal challenges to article 53 of the Act. The nullification of the political participation aspect of the CS Act does not necessarily politicise the Maldivian CS. Civil servants are still required to provide impartial and unbiased service to all citizens. Several references to such principles are laid down in the CS $\mathrm{Act}^{125}$ and in the code of conduct ${ }^{126}$. Any action contrary to such principles can be sanctioned by the CSC within the confines of the legislation.

In practice, civil servants in the Maldives appear to have accepted as the norm that they enter the service with the knowledge that restrictions will be placed on them regarding political participation. Several interviewees reiterated this aspect (Interviewees FO1, FO5, FO8, FO11, GO1, GO2, GO3, GO4, PL2). So far there have been very few instances in which civil servants have been caught up in controversies regarding political participation. A number of such incidents are discussed in the following chapter (section 7.3.1).

Maintaining a clear separation between public duty and private interest is also an important aspect for an apolitical CS. In this regard, the CS Act ${ }^{127}$ and subsequent regulations ${ }^{128}$ contain a number of specific provisions covering conflict of interest, adherence to professionalism, and impartiality in dissemination of duties. There are penalties in law for violations of these principles. However, as the provisions are relatively new, there is currently very little evidence of their effectiveness. ${ }^{129}$

As discussed in the previous chapter (section 5.4.8), the Maldives had a long tradition of government employees being appointed at the discretion of the president.

\footnotetext{
${ }^{125}$ Article 4a, 4b, 5a, and $18 \mathrm{~b}$.

${ }^{126}$ Clause 25b, 25c, 25g, 25h and 27h of MCSR.

127 They include professional responsibility of civil servants (article 26), service guidelines (article 27c), disclosure of information (article 28c, and 28e), secrecy (article 29), and misuse of authority (article 36).

${ }^{128}$ According to the MCSR, they include professional standards (clause 9dii and 9diii), utilising office resources (clause 15, 18 and 21), prohibition of personal work during official hours (clause 17), and attire (chapter 16). ${ }^{129}$ Transparency International (2011) reported that among the South Asian countries, civil servants in
the Maldives were perceived to be the least corrupt.
} 
The powers of the president to manoeuvre state employees at his will, as mentioned previously (section 6.5), has been cited as one of the reasons for establishing a CS independent of the political executive. While maintaining the powers of the political executive to direct the CS in matters of public policy, the Act significantly reduced the president's direct control in matters of employment. What control remained has been further reduced since the passage of the Act. An amendment to the Act in 2010 transferred the president's role in appointing and dismissing the CS commissioners to the majlis and removed his power to nominate the chairperson and deputychairperson of the CSC for the majlis's approval. ${ }^{130}$

These further changes followed the political turmoil that the nation experienced after the parliamentary election of 2009. They reflected ongoing tensions between the principle of neutral competence and the duty of civil servants to the elected government. These tensions played out in other conflicts between the political executive and administration and are discussed at greater length in the next chapter.

\subsubsection{Employment rights and protection.}

Another key feature of classical Weberian bureaucracy is the expectation that civil servants should be employed within the CS until retirement, subject to adequate performance. In line with the global shift away from such practices, the "job for life" concept appears to have eroded in the Maldives as well. Along with different strategies used to trim and reshape the CS, the protection that was once associated with state employment no longer holds sway. However, for those staff that remain under the scope of the CS, significant restrictions are still in place against arbitrary dismissal.

Protection for civil servants from unfair dismissal is provided by both the CS Act and the Employment Act. The Employment Act states that as a general principle:

An employee shall not be dismissed from employment without showing appropriate cause as to failure to maintain work ethics, inability to carry out

\footnotetext{
${ }^{130}$ Chairperson and the deputy-chairperson are chosen from the five commissioners.
} 
employment duties and responsibilities related to the proper functioning of his place of work; even after measures have been taken to discipline the employee or upgrade skill deficiencies. (Article 21a)

Under the CS Act, the grounds on which a civil servant can be dismissed include: inability to perform duty; failure to complete a training programme; violation of CS regulations; proven retention of employment in violation ${ }^{131}$ of the law and regulation; and contesting public office (Article 47). No reference to restructuring or downsizing is given. Generally, notice is also required before dismissal and whistle-blower protection is also ensured under the law. Such measures and specific criteria for dismissal ensure that, although tenure for life no longer exists, significant protection against unfair dismissal is still in place in the Maldivian CS.

Specifying employment rights in such detail in the CS Act and the Employment Act along with subsequent regulations was an intentional decision taken by the policy makers. To some extent, such aspects were covered in rules, regulations, and systems even before the statutory CS was established (Interviewee GO7). However, there were constant accusations that civil servants were being dismissed unfairly (Interviewees GO7, PL2) which appears to be one of the reasons for a number of MPs pursuing the establishment of a statutory CS (Interviewee PL1). Providing significant details on the mechanisms to protect the rights of the employees was thus believed to be due to alleged abuse of the rules in the past.

Restrictions on career civil servants from undertaking additional employment are also a key feature in the classical Weberian CS model. In the Maldives, only few such restrictions exist. As mentioned in the previous chapter (section 5.4.6), the smallness of Maldivian society means that a number of individuals have multiple roles. Furthermore, the inability of a government job to adequately support a family has created a culture in which public officials are normally allowed to have multiple jobs, in many cases one within the government and another in the private sector. The CS regulations have however put significant restrictions on additional employment

\footnotetext{
131 That includes falsifying documentation during application for the job.
} 
for a number of professions in the CS to prevent any possible conflict of interest ${ }^{132}$ that may arise. As compensation, additional financial incentives are often provided for these professions. Protection of professional integrity is given prime importance, as discussed earlier (see section 6.8.11). Although disclosure of personal wealth is not required for any civil servant and most of them have the right to seek a secondary job, the code of conduct applies to all civil servants which promote professionalism. Nevertheless, the provision for most civil servants to seek extra employment in the Maldives opens the possibility of conflict of interest.

\subsubsection{Disciplinary procedures.}

A further feature of the classical CS model is a pre-defined disciplinary procedure for breach of the code of conduct. Special disciplinary legislation is also enacted in some countries with features of the classical model. Although the Maldives do not have a specific law in this respect, the processes followed in the Maldivian CS are closely aligned with the classical model.

According to the code of conduct, civil servants should interact with others fairly, impartially, courteously, and considerately. Working relationships between employees are also governed by the code; for example, a conducive work environment where lawful instructions of the superiors are to be followed effectively. There is extensive detail on how employees should proceed in fulfilling their duties. The attributes expected from each civil servant include effectiveness, efficiency, innovativeness, professionalism, accountability, confidentiality, and abstaining from conflict of interest and graft.

Most of the principles and attributes outlined in the code existed in regulations before the CS Act. However, since inception of the CS, they have been clearly laid out in detail for the first time. Though the time frame provided for the civil servants to become familiar with these detailed guidelines was short, they appear to have adapted to the new code relatively well. Several interviewees are adamant that most civil servants adhere to the code of conduct (Interviewees CV1, FO1, FO5, FO6,

\footnotetext{
${ }^{132}$ For instance, government lawyers and doctors, some of whom also have private practices.
} 
FO8, GO2, GO5). Only a few instances of violation have been cited (see section 7.3.1).

If a civil servant is found in violation of the code, the legal basis for disciplinary measures is provided in the CS Act and the Employment Act. Measures that can be taken include advising, reprimanding, re-assignment of duties, fine, reduction in classification, and dismissal. Offences under which such measures can be taken are listed in the CS regulation. While individual organisations can take disciplinary measures for lesser offences, the CSC takes direct action for severe offences. The employee retains the right to appeal the decision of the CSC to the Maldives Employment Tribunal (Clauses $12 \& 242$ of MCSR). The decision of the Employment Tribunal can be further appealed at the Maldives High Court (Article 86 of Employment Act). Grievance procedures are discussed in more detail in the following section.

Disciplinary procedures are, in general, the same as were followed before the statutory CS. Although the CSC has provided additional detail on the offences that can constitute breaking of the code of conduct, knowledge regarding such practices appears to be relatively institutionalised in the CS.

\subsubsection{Grievance procedures.}

Civil service laws generally have some provision for appeal or review of decisions based on the principle of the right to due process. The Maldivian CS Act provides similar provisions. According to the CS Act, a transparent, fair, and reasonable appeal system should be established to review decisions that are considered unjust by civil servants (Articles $4 \mathrm{~g} \& 4 \mathrm{~h}$ ). The first point of contact to report any breach of law or regulation is the PS or the highest ranked civil servant in the organisation (CS Act, 2007, Article 30). If the decision taken remains unsatisfactory, the case can be submitted directly to the CSC (CS Act, 2007 Article 31). Cases where the complaint is against the PS, or the highest ranked civil servant can be submitted directly to the CSC (Clause 236c of MCSR). 
Investigation of cases submitted to the CSC is normally carried out by legal staff at the CSC (Clause 239e of MCSR). However, the CSC can choose to investigate the case through a standing committee ${ }^{133}$ although the decision of the committee is not binding. After the commission makes its final decision, the civil servant has the right to appeal the decision to the employment tribunal.

The procedures followed in the Maldivian CS appear to be in line with most other statutory civil services. As far as statistics on such cases are concerned, no central organisation has maintained records of cases submitted to courts prior to the establishment of the CSC making it difficult to compare trends before and after the statutory CS was established (refer to section 5.4.8 on the grievance procedures before the statutory CS). However, records collected recently show a degree of awareness among the civil servants regarding their rights and protection (see table $6.17)$.

Table 6.17: Cases submitted to employment tribunal and the courts

\begin{tabular}{|l|c|c|c|c|}
\hline & \multicolumn{2}{|c|}{ Employment Tribunal } & \multicolumn{2}{c|}{ Courts } \\
\hline & Submitted & Completed & Submitted & Completed \\
\hline 2009 & 51 & 33 & 3 & 1 \\
\hline 2010 & 195 & 101 & 52 & 2 \\
\hline 2011 & 35 & 21 & 40 & 21 \\
\hline
\end{tabular}

Source: CSC (2011a); CSC (personal communication, December 11, 2011)

\subsubsection{Pension and retirement.}

As discussed in section 2.3.19, a special statutory pension scheme for civil servants was a common feature of the classical CS model. Presently, however, with changes in economy and demography, many countries are reforming their pension schemes. That includes moving away from specific CS pension schemes towards general pension schemes. Additionally, countries are moving to fully funded employeeemployer contributing schemes with changes to their retirement ages.

\footnotetext{
${ }^{133}$ Comprises a senior lawyer at the CSC, a lawyer assigned by the legal consultant of the CSC, an independent lawyer, a representative of the Labour Relations Authority, and a member from the Human Rights Commission (Clause 239a of MCSR).
} 
The reform of the pension in the Maldives reveals a move along similar lines. As indicated in the previous chapter (section 5.4.7), in the absence of any law governing pensions, a specific pension scheme existed for all government employees before the Pension Act of 2009. Pensions were fully funded by the government and did not require any contribution from the employee. The CS Act as well as the Pension Act completely changed the picture.

Firstly, the CS Act introduced mandatory and voluntary retirement ages for the first time. Secondly, the Pension Act covers all state employees as well as private sector employees and made the pension scheme a contributory scheme to which both the employee and the employer contribute equally. ${ }^{134}$ Such sweeping reforms were highly debated during the parliamentary stages of the CS bill (see section 6.4.4). Attempts by the government in 2008 to delay implementation of the retirement age by submitting a CS amendment bill showed the sensitivity of the issue to Maldivian society (see section 7.4.3). Nonetheless, the implementation of the CS retirement age and the general pension scheme, both politically sensitive issues, has been successful.

\subsection{Overseas influences on the Maldivian civil service model}

As discussed in the previous chapter (section 5.2), although in an autocratic mode of governance, there has been a CS in the Maldives in one form or other for many centuries. The administration of state officials has evolved over that time by adapting local institutions with some borrowing from other jurisdictions. However, the deliberate framing of a statute to align with concepts and practices of other countries was a significant departure in some aspects. This section examines the possible aspects of policy transfer and influences from other civil services in shaping the Maldivian CS model.

The Maldivian CS model cannot be considered a direct emulation of a single foreign CS system. During the submission of the bill, Ahmed Nazim said that reference was made to the Australian Public Service Act, Canadian Public Service Employment

\footnotetext{
${ }^{134}$ Until the Pension Act came into force, the CSC devised a pension scheme that was fully funded by the government. This provisional scheme was abandoned once the contributory pension scheme started.
} 
Act, and the Latvian State Civil Service Law (Nazim, 2005a). These laws represented a mixture of borrowing from established democracies and emerging democracies. Furthermore, in relation to participation in political activities and political influences, the chairperson of the parliamentary committee also revealed that practices in countries like the United Kingdom, Canada, Australia, New Zealand, India, and Singapore were studied during the committee stage (Shareef, 2007). References made to the laws of other countries show that a degree of policy transfer occurred in the formulation of the Maldivian CS Act (refer to section 2.6 on policy transfer).

Several components in the original CS bill, introduced by Nazim, were new to the Maldivian context. These include the concept of merit, an independent commission to run the affairs of the CS, a senior executive service, permanent secretaries independent of the political leaders as the operational head of government ministries, management advisory committee, whistle-blower protection, retirement, a public service minister, and a CS tribunal. For all these practices there were established precedents in the laws of other countries that could serve as inspiration, models, or templates for the Maldivian CS Act. One interviewee said, all that was done was "fine tuning" to adjust to the Maldivian cultural and societal norms (Interviewee FO10). Another said that there was no need to reinvent the wheel and all that was needed was modification to suit our society (Interviewee FO4).

With the transfer of concepts and practices from other countries, attempts were made to adapt the Maldivian CS Act to be in line with what is considered "best practice". It was an important aspect raised by several MPs during the parliamentary debates. As mentioned in Chapter Two (section 2.3.3), the OECD (1996) identified a minimum of four main objectives needed in such legislation in order for it to be aligned with best practice. Table 6.18 shows how these objectives correspond with the CS Act of the Maldives. 
Table 6.18: Correspondence of OECD objectives to the Civil Service Act

\begin{tabular}{|l|l|}
\hline Objective & Maldives Civil Service Act \\
\hline $\begin{array}{l}\text { Raising professional quality of staff; degree } \\
\text { of independence for civil servants; ethical } \\
\text { standards. }\end{array}$ & $\begin{array}{l}\text { Provide leadership and training to civil } \\
\text { servants (Article 18m); enhance apolitical } \\
\text { service provision (Article 18b); protection of } \\
\text { civil servant rights (Article 18c); develop } \\
\text { monitoring mechanism to enforce the } \\
\text { regulation (Article 18g) }\end{array}$ \\
\hline $\begin{array}{l}\text { Government's ability to change } \\
\text { administration. }\end{array}$ & $\begin{array}{l}\text { President has the authority to create, abolish, } \\
\text { and determine the mandate of government } \\
\text { organisations (Article 64a) }\end{array}$ \\
\hline Enhance legitimacy of the CS & $\begin{array}{l}\text { Develop a competent CS (Article 18b); } \\
\text { establishing a transparent system that } \\
\text { provides reasonable and equal opportunity to } \\
\text { anyone to apply to positions of the CS } \\
\text { (Article 4i). }\end{array}$ \\
\hline Develop an attractive CS & $\begin{array}{l}\text { Develop a career-based service with } \\
\text { opportunities (Article 181) }\end{array}$ \\
\hline
\end{tabular}

\subsection{Conclusion}

In some respects, the new CS Act adopted in the Maldives is a significant departure from the past. This is mainly due to the political agenda of restricting the power of the president in managing public employment. Reflecting the fairly narrowly focused political agenda during the CS bill's debates, the main disagreements were based on a few significant issues (such as scope of the CS), while other significant issues of principle (such as the functions of the CSC) received relatively less attention.

The language in the CS Act reveals a degree of policy transfer from foreign statutes. Such borrowing may be both a conscious desire to take on board some of the principles in a particular model of CS found in other jurisdictions, and also simply the convenience of having ready-made solutions from other statutes to specific issues of the CS. The result is the Maldivian CS Act which in some respects embodies classical CS principles, particularly regarding political neutrality, but in others, a relatively open system of employment that reflects past practices in the Maldives. 
Since its enactment in 2007, the CS Act has undergone substantive amendments (see section 7.4.3). This could be interpreted as a measure of its technical quality as a piece of law, but in the present uncertain political environment, its future as a means of institutionalising a statutory CS for the long term remains in question.

Based on the analysis presented in this chapter, table 6.19 summarises the CS model adopted in the Maldives. The next chapter focuses on the impact this model has on the democratisation process as well as the impact of democratisation process on this particular CS model.

Table 6.19: The civil service model of the Maldives

\begin{tabular}{|c|c|}
\hline Characteristics & Application in the Maldivian CS \\
\hline Legal basis & $\begin{array}{l}\text { General principles stated in the constitution. } \\
\text { Details stated in the CS Act and regulations. }\end{array}$ \\
\hline Horizontal scope of the CS & $\begin{array}{l}\text { Central government and local government } \\
\text { part of the CS. Schools and hospitals that are } \\
\text { not corporatised are part of the CS. Political } \\
\text { appointees, judiciary, legislature, security } \\
\text { forces, public enterprises, and any statutory } \\
\text { organisation stated as not part of the CS, are } \\
\text { excluded from the CS. }\end{array}$ \\
\hline Overall management of the CS & Centrally managed by the CSC. \\
\hline Code of conduct & $\begin{array}{l}\text { Retention of a code covering detailed } \\
\text { behaviours. More extensive compared to the } \\
\text { code before the statutory CS. }\end{array}$ \\
\hline Categories of civil servants & $\begin{array}{l}\text { Permanent civil servants, temporary civil } \\
\text { servants, contract staff, and volunteers. This } \\
\text { allows flexibility in hiring. }\end{array}$ \\
\hline Type of merit system & $\begin{array}{l}\text { Preference on academic results followed by } \\
\text { experience (often measured in seniority). } \\
\text { Merit used both for recruitment and }\end{array}$ \\
\hline
\end{tabular}




\begin{tabular}{|c|c|}
\hline & promotion. \\
\hline Enforcer of merit & The CSC appointed by the parliament. \\
\hline Type of recruitment system & $\begin{array}{l}\text { Mixture of career-based and position-based } \\
\text { systems - the aim is to hire the best } \\
\text { candidate for each position, either from } \\
\text { within or outside the CS. Provision for } \\
\text { lateral entry. No entry examination. } \\
\text { Centralised approval rigidly enforced by the } \\
\text { CSC. }\end{array}$ \\
\hline Recruitment practices & $\begin{array}{l}\text { Use of interview panel with relatively } \\
\text { uniform guidelines for interviewing. }\end{array}$ \\
\hline Entry requirements & $\begin{array}{l}\text { In addition to educational qualifications and } \\
\text { length of service in the public sector, private } \\
\text { sector experience can be counted for } \\
\text { approximately same levels of jobs. }\end{array}$ \\
\hline Type of job classification & $\begin{array}{l}\text { Unified system with features of "rank-in } \\
\text { job" and "rank-in person" systems - } \\
\text { positions classified according to differences } \\
\text { in job duties with equal pay for equal type of } \\
\text { work; advancement to higher levels based on } \\
\text { a combination of length of service and } \\
\text { performance. }\end{array}$ \\
\hline Rewards & $\begin{array}{l}\text { Salary system includes a base salary and a } \\
\text { fixed service allowance. A mixture of other } \\
\text { allowances provided based on the type of job } \\
\text { and time/place of work. All monetary } \\
\text { rewards determined by the CSC in } \\
\text { consultation with MOFT. An annual salary } \\
\text { increment system based on performance in } \\
\text { place (not operational yet). }\end{array}$ \\
\hline Promotion & $\begin{array}{l}\text { Promotions based on a combination of } \\
\text { length of service and performance. Possible }\end{array}$ \\
\hline
\end{tabular}




\begin{tabular}{|c|c|}
\hline & $\begin{array}{l}\text { only when a vacant position needs to be } \\
\text { filled. Internal and external candidates need } \\
\text { to compete. Educational qualification can be } \\
\text { used to "jump" to certain grades. } \\
\text { Performance measured annually using a } \\
\text { performance appraisal form developed by } \\
\text { the CSC. }\end{array}$ \\
\hline Political participation & $\begin{array}{l}\text { Participation in politics limited to ensure } \\
\text { neutral service provisions. }\end{array}$ \\
\hline Political/administrative interface & $\begin{array}{l}\text { Little direct control of the CS by the political } \\
\text { executive. No limit to the number of political } \\
\text { appointees. Provision for political } \\
\text { appointments to perform the CS duties. } \\
\text { President can create, abolish, and determine } \\
\text { the mandate of government organisations. }\end{array}$ \\
\hline Protection of employment & $\begin{array}{l}\text { Relatively low degree of protection in some } \\
\text { sectors. Main threat due to prerogatives of } \\
\text { the president who can enforce re- } \\
\text { organisations that could result in removing } \\
\text { parts of the organisation or entire } \\
\text { organisations from the CS. }\end{array}$ \\
\hline Employment rights & $\begin{array}{l}\text { Provisions in both the CS Act and the } \\
\text { Employment Act. }\end{array}$ \\
\hline $\begin{array}{llll}\text { Restrictions } & \text { on } & \text { seeking } & \text { additional } \\
\text { employment } & & & \\
\end{array}$ & $\begin{array}{l}\text { No general restriction on secondary } \\
\text { employment except for civil servants of } \\
\text { selected organisations and professions. } \\
\text { Financial incentives provided for such civil } \\
\text { servants. }\end{array}$ \\
\hline Disciplinary procedures & $\begin{array}{l}\text { In normal circumstances following a } \\
\text { sequence of advice, written caution, } \\
\text { temporarily reassigning tasks, suspension, } \\
\text { demotion, and dismissal. Exceptions allowed } \\
\text { depending on the nature of the offence. }\end{array}$ \\
\hline
\end{tabular}




\begin{tabular}{|l|l|}
\hline & $\begin{array}{l}\text { Suspension, demotion, and dismissal often } \\
\text { require approval from the CSC. }\end{array}$ \\
\hline Grievance procedure & $\begin{array}{l}\text { PS, the CSC, employment tribunal, judicial } \\
\text { courts can be approached. }\end{array}$ \\
\hline Pension and retirement & $\begin{array}{l}\text { General pension scheme under the Pension } \\
\text { Act which covers both public and private } \\
\text { sector employment. Voluntary retirement at } \\
\text { age } 55 \text { and mandatory retirement at age } 65 . \\
\text { Pension at a reduced rate can be taken by } \\
\text { retiring at age 55. }\end{array}$ \\
\hline
\end{tabular}




\section{CHAPTER 7: CIVIL SERVICE IN AN EMERGING DEMOCRACY}

\subsection{Introduction}

A statutory CS and modern system of governance based on democratic principles are relatively new to the Maldives. Consequently both the CS and democratic ideals in the Maldivian context are at a state of evolution. This chapter argues that the model of CS chosen for the Maldives has a significant bearing on the democratic process and, conversely, the democratic process due to its infant stage hinders the attempt to institutionalise a professional CS in the Maldives.

The chapter is divided into three main parts. The first part focuses on the impact that the CS model is having on the democratisation process. The second part examines how the democratisation process is affecting the CS model. The last section examines the features that the Maldivian CS exhibits in the context of an emerging democracy. Though such features are not unique to emerging democracies, the observations from the interaction between the CS and democratic reforms in the Maldives are argued to be directly related to the emergence of democracy.

\subsection{Impact of civil service model on the democratisation process}

Reform of the CS has been an integral component of the democratic reforms of the Maldives. Examination of the administrative practices of the Maldives, as shown in Chapter Five, reveals that most of the basic tenets of a CS were present even prior to the enactment of a law governing those aspects. Nonetheless, formulation of a statutory CS paved the way for the lawmakers and policymakers to shape the CS model as they deemed appropriate. The previous chapter showed the chosen model to be significantly detached from the political executive but with the previous centralised features of administration retained. The model also had provisions in which the CS could play an important role in national development. This section presents these three aspects of the model and how they influence the democratisation process underway. 


\subsubsection{Impact of the independent model.}

As discussed in the previous chapter, the CS model chosen for the Maldives provides relative independence of the CS from the political executive. The de-linking set in motion a process in which both the CSC and the president tested the limits of their respective authority. The following sections highlight the major episodes that unfolded in this regard.

\section{Challenges at inception.}

The effects of de-linking the CS and the political executive were evident even before the CS Act came into force. As stated in the previous chapter (section 6.4.10), although the CS bill was ratified by the president on May 2, 2007, the Act had a provision for one year to fully establish the CS. Soon after the commissioners were appointed on October 23, 2007, preparation to take charge of their responsibilities started. In this regard, the commission was aiming to take full responsibility regarding personnel management of all civil servants by the beginning of 2008 (Hamdhoon, 2007). However, the chairperson of the commission revealed in late January 2008 that the commission had not received a response from the government on transferring the work from the PSD to the CSC and accused the government of having a "political view" on the matter (Hamdhoon, 2008a). The chairperson also said:

This is something that should be done by both the president's office and the civil service commission. So both parties need to talk in a civilised manner by sitting on both sides of the table. If there is a difficult issue, we need to solve it. We want to go ahead in a manner where the service given to the public is not disrupted. We can transfer something that they have to us, only through negotiation. (Hamdhoon, 2008b, translation)

The issue was eventually resolved when the president issued a decree to hand over the personnel management functions of the PSD to the CSC from March 2, 2008 (Presidential Decree No. 2008/1). 


\section{Disputes between the CSC and government.}

A common platform for dialogue between the CSC and the government has been absent at times. Consequently, as soon as the CSC had control over the personnel management function at the beginning of March 2008, it was arguably determined to show its independence rather than subservience to the government of the day. Relations between the CSC and government were first tested in early March 2008 when the government submitted a CS amendment bill (see section 7.4.3) to the parliament which aimed at changing the horizontal scope of the CS, thereby removing a number of organisations and positions from the authority of the CSC. A government minister revealed that although feedback on the bill was requested from the CSC, the commission refused to get engaged in any discussion regarding the proposed amendments (Nasheed, 2008a). ${ }^{135}$ Later on the commission raised its concerns in the media regarding the proposed amendments to the bill (Hamdhoon, 2008c).

Election of a new government in November 2008 once again led to numerous disputes between the CSC and the government. Although the newly-elected government was seeking to make the CS smaller through corporatisation and redundancies, the commission raised concerns about the policies: in particular, the government's attempt to enforce the provision for voluntary retirement at the age of 55 throughout the CS (Hamdhoon, 2009a).

Soon afterwards, in early April 2009, the CSC was summoned to the internal affairs committee of the parliament after President Nasheed sent a letter to the parliament complaining of what he saw as "lack of support" from civil servants and the CSC in implementing government's policies (Hamdhoon, 2009b). However, in a press release, the commission denied the allegations made by the president and reiterated its legal obligation in following the CS Act and regulation as far as personnel management was concerned (Hamdhoon, 2009c).

\footnotetext{
${ }^{135}$ Reference is made here to Mohamed Nasheed who served as a minister in the Gayoom government. He was elected to the parliament in 2009. He is an independent MP and a lawyer by profession. He is not the former president who has the same name.
} 
Relations between the commission and the government did not fare any better during campaigning for the parliamentary election in April 2009. After numerous reports of abuse and threats towards civil servants by political appointees, the CSC announced it would go to the court regarding the threats (Hamdhoon, 2009d). Once the parliamentary election was over, a number of senior politicians openly accused the commission of challenging the government and creating what they perceived as a "state within a state" (Hamdhoon, 2009e, translation).

The appointment of "responsible officers" by the CSC to island and atoll offices was also not a popular move as far as the government was concerned. Soon after the appointments were made in early 2009, the government expressed its reservations on the matter (Hamdhoon, 2009e). However, the CSC reiterated that it was a "misconception" that new positions were created: rather they were added responsibilities for the highest ranked civil servant in island and atoll offices ("Civil Service Commission Responds," 2009). After the Minister of Home Affairs ordered the cancellation of the allowance to the responsible officers, the CSC submitted a case to the civil court to order the government to reinstate the allowance (Hamdhoon, 2009f). On February 9, 2010, the civil court ruled in favour of the CSC (Hamdhoon, 2010a).

The biggest fallout between the CSC and the government came after the government instituted austerity measures in which salaries of all state employees were reduced from October 2009. The reduction for civil servants was enforced by an agreement between the government and the CSC. According to the CSC the reduced salaries would be in place for three months in accord with article $43^{136}$ of the CS Act ("Civil Servants' Salaries," 2009). At the end of the three-month period, the government and the CSC provided different interpretations of the agreement between them. The government's position was that the austerity measures were needed to ensure economic recovery, while the CSC claimed that the proposed budget for 2010 included sufficient revenue to reinstate the previous salaries. As a result, the CSC

\footnotetext{
${ }^{136}$ Aricles 43(c) and (d) of the CS Act state respectively that, "Upon consultation with Minister of Finance and Treasury, the Commission has the discretion to alter the salary and benefits paid under subsection (a) for a determined period regarding an extraordinary condition" and "The decision made under subsection (c) shall be revised in every three months. Where the cause of the alteration is over, the benefits prior to the alteration must be enforced".
} 
directed government ministries to reinstate the salaries effective from the beginning of 2010 (CSC, 2009b). However, when the government refused to reinstate the salaries of civil servants but reinstated salaries of other statutory bodies, the CSC took the government to court ${ }^{137}$ once again. In retaliation, the MOFT submitted a case to the police accusing the CSC of attempting to topple the government (Hamdhoon, 2010b).

\section{Disputes between civil servants and politicians.}

The dual accountabilities of civil servants to their ministers and to the CS Act have often been a source of friction. As mentioned in the previous section, one of the main complaints of the first democratically elected government arose from perceived "lack of support" from the CS. Government MPs and political appointees raised this issue on several occasions. For instance, in a parliamentary session just after the change of government in November 2008, MPs aligned with the government accused civil servants of being disloyal to the elected government and called on the CSC to take disciplinary action against them (Moosa, 2008a). Such political rhetoric against civil servants was observed on several occasions.

Disputes between ministers and civil servants have gone public on several occasions. In one instance, in June 2009, the Minister of Human Resources, Youth and Sports and his PS had a public falling-out regarding an advertisement for a number of vacant positions which the minister asserted were contradictory to government policies (Haleem, 2009; Interviewee FO3). Although the PS was acting within his legal authority, a lack of a common vision for the organisation between the PS and the political appointees can often be the reason for such fall-outs.

As stated in the previous section, one the biggest fallouts between the CS and the government was during the salary disputes in early 2010. When the CSC and the government took diverging stances on the matter, intense pressure was put on some

\footnotetext{
137 The civil court delivered its judgement on April 27, 2010, in favour of the CSC. Government appealed the case to the High Court, which once again ruled in favour of the CSC on May 10, 2011. The High Court judgement was appealed to the Supreme Court, which also ruled in favour of the CSC, on February 16, 2012.
} 
civil servants, especially on the finance officers who prepare the organisational salary slips (Interviewee FO3). While the CSC, through its permanent secretaries, directed the finance officers to prepare salaries based on reinstated salaries, the government, through its ministers, ordered those same finance officers to prepare the salaries based on the reduced level. At the height of the saga, both the CSC and the government threatened those finance officers with legal action (Hamdhoon, 2010c; Hamdhoon, 2010d). During this period, contrary to the CS Act, the Minister of Defence even suspended his PS when the PS instructed the finance officers to prepare the salary sheets based on the reinstated salaries (Hamdhoon, 2010e).

These accounts of disputes over staffing numbers and determining pay call into question the legal basis for determining the staffing of government ministries of the CS. As explained in section 6.8.3, although the organisational aspects of staffing rest with the CSC, the MOFT is arbiter on financial matters. These events are an example of a disagreement, fairly common internationally, between a personnel authority with control over staff numbers and remuneration in the public sector and a treasury with the authority to manage public expenditure through a budget, but they also reflect the wider conflict between the CSC and the political executive over management of the CS.

\section{Presidentialism and constitution.}

It was stated in Chapter Four (section 4.3.3) that establishment of a statutory CS was one of the main components of the democratic reforms. Though the CS bill and the constitutional amendments were proceeding concurrently, the CS bill became law before deliberations on the new constitution were completed. More importantly, the Act was ratified on May 2, 2007 before the constitutional assembly decided which form of government - presidential or parliamentary - would be enshrined in the constitution. As mentioned in the previous chapter (section 6.7), when passing the CS bill, MPs also reiterated the importance of amending the Act to align it with the new constitution that was yet to be finalised. The detachment of the CS from the presidential form of government that was decided upon and the inability to amend the CS Act accordingly, as discussed in this chapter, have created friction in the attempts to institutionalise a professional CS. As a result, questions have been asked 
regarding the compatibility of such an independent model of the CS with the present presidential form of governance (Interviewee FO5). After the presidential form of governance was confirmed by a public referendum, in August 2007, the government also raised the importance of re-adjusting the CS to suit presidentialism (refer to section 7.4.3). The argument of incompatibility hinges mainly on the detachment of the CS from the head of the state.

After the CS came into operation at the start of May 2008 while the 1998 constitution was still in effect, a stern constitutional test followed. At that stage, ten civil servants who were also in the people's special majlis challenged the CSC in court when those civil servants were ordered to choose between the CS job or the majlis seat. While those civil servants argued they were elected under the 1998 constitution which was still in effect, the commission argued that under the CS Act no civil servant could hold an elected seat. Though both the Civil Court and the High Court ruled in favour of the civil servants, the commission stood firm. Only when the highest judicial authority, the president (see tables 4.2 and 4.3), ruled in favour of those civil servants just before the 2008 constitution was ratified, did the commission agree to reinstate them, but by then the special majlis was dissolved. This "chicken or egg" case of the CS Act and the constitution was regarded as a test of the independent nature of the CS from other state institutions.

\subsubsection{Impact of the centralised model.}

The examination of administration before the formulation of the statutory CS in Chapter Five with the examination of the CS model of the Maldives in Chapter Six has shown that centralised administrative practices have largely been retained in the statutory CS.

The 2008 constitution ensures a high degree of accountability from state officials. Parliamentary overseeing of government functions has increased significantly under the current governance structure. Several civil servants have been summoned to parliamentary committees recently. This was uncommon before the current constitution. Previously, ministers were both political and administrative heads of their ministries. The change in the accountability framework has come in the wake of 
the democratic reforms in which the public usually demands a high degree of accountability and responsiveness from state officials. With the separation of the administrative and political roles within the organisations and the constant public demand for better services, elected leaders often in turn increasingly demand faster and more efficient service from the civil servants. When the services are not delivered in such a manner, tensions arise. Part of this tension is due to the centralised model.

The effects of the centralised model are mostly seen in the outer islands. The atoll and island councils elected for the first time by competitive elections, appear to be under significant pressure from the public to deliver better services. However, some councils argue that, in order to match growing public demands, they need greater authority in personnel management functions and setting benefits for civil servants working in the councils. The present route whereby the councils have to send personnel management requests to the central ministry which passes those requests to the CSC is the same mechanism that existed before the CS. The time taken during the lengthy process may hinder the efforts to provide faster and better services to the public.

There are other instances, too, when the centralisation of administration has been questioned. For instance, in March 2011, the Male' City Council accused the CSC of not providing it with technical assistance which, the council said, was hindering the services it intended to provide to the public (Naafiz \& Ahmed, 2011), though such accusations were rejected by the commission (Hamdhoon, 2011). In another instance, in July 2009, the Controller of Immigration and Emigration also raised the issue of rigidity and difficulties in working within the existing rules and regulations of the CS and expressed his desire to remove the organisation from the CS (Ashiya, 2009a).

These issues are due to the lack of authority given to the organisations. As examined in the previous chapter (section 6.8.3), approval from the CSC is required for all personnel management functions. Due to such centralised approval procedures, politicians often brand the CS as "slow", while the CSC asserts it is simply following the rules. 


\subsubsection{Impact on national development.}

As emphasised in Chapter Five (section 5.4.7), for many years government played a major role in the social and economic development of the Maldives. As a result, the CS was also designed to maintain the provision for the government to deliver services to the public as deemed appropriate by the government. According to article 26 of the CS Act, civil servants were expected to assist the government in implementation of the policies and programs of the government.

It can be argued that alternative forms of public organisations such as SOEs are more efficient or responsive for some types of services and should not be constrained by the rules of the CS. The underlying issue here is which services as a matter of principle should be provided by the civil servants directly accountable to the government or by SOEs or by the private sector.

Nasheed's government embarked on an extensive corporatisation agenda (see section 6.8.2). Several organisations that belonged to the CS were corporatised. That this trend is reversing since his resignation, with some corporations being moved back into the CS, indicates that the role which the CS can play in service delivery depends entirely on the government of the day (Interviewees FO6, GO4, GO6).

The role of the CS in the national development of the Maldives is evolving along with the political changes. Despite the changes, many believe the "knowledge bank" that the CS possesses through some of the highest qualified personnel in the country can be used as a catalyst for national development (Interviewees FO8, FO9). As one interviewee said, "civil service is the brain of the nation and politicians in an organised society will base their decision on the professional advice from civil service" (Interviewee FO4). Others believe the emphasis should be on service delivery, and whether the services are provided directly by the CS or SOEs is irrelevant (Interviewee MD1). Currently, the Maldivian CS retains significant roles such as provision of municipal functions, education, and a significant portion of health services, all of which are important for national development. 


\subsection{Impact of democratisation process on the civil service model}

The previous section (section 7.2) examined how the CS model influences the democratisation process. This section, conversely, examines how the democratisation process affects the CS model. To achieve this objective, the analysis focuses on the three types of politicisation of the CS that were described in Chapter Two (section 2.4.2): internal-driven politicisation, society-driven politicisation, and politician-driven politicisation. The main argument here is that the high degree of politicisation is mainly due to the model of CS adopted in the Maldives.

\subsubsection{Internal-driven politicisation.}

In basic terms, this type of politicisation arises when civil servants themselves are involved in political activities. As mentioned previously (section 6.4.5), civil servants have no restrictions on becoming a member of a political party although they are not allowed to be politically active. Article 53 of the CS Act was the main pillar restricting civil servants. However, the constitution that was ratified in August 2008, only a few months after the statutory CS came into life, provided for political freedom for all citizens. Immediately the CS Act was put in the spotlight when a number of cases involving political participation of civil servants surfaced.

One of the most high profile case was in August 2008, when the Director General of one of the ministries participated in a political rally, where he openly pledged his support for President Gayoom. He was subsequently demoted by the CSC, a decision challenged in the court without success. As the campaign for the presidential election was in full swing, a number of such incidents came into the public domain, resulting in a media release by the CSC warning civil servants (CSC, 2008). In total the commission demoted six civil servants - including the head of a drug rehabilitation centre in the southern island of Gan and the Director General of the Department of Medical Services - as well as handing out other disciplinary measures, such as advising and reprimanding a number of civil servants (F. Ahmed, 2008; Hamdhoon, 2008d; Shifleen, 2008). 
The restrictions placed on the political activities of all civil servants were seen by a number of civil servants as violation of their constitutional rights. As a result, a civil servant submitted a case to the High Court in September 2008 to nullify article 53 of the CS Act. On December 3, 2008, the High Court ruled that article 53 of the Act violated the constitutional rights and thus was invalid. The court delayed the implementation of the ruling for three months in order for the CS Act to be amended so that the restrictions on political participation could be limited to an extent that was justified in a free and democratic society (Hanim v. Government of the Maldives, 2008). Rather than pursuing an amendment to the Act, government appealed the decision to the Supreme Court, which also upheld the High Court's decision on September 19, 2011 (Government of the Maldives v. Hanim, 2008/2011).

Due to the failure to amend the Act accordingly (see section 6.8.11), the chapter on political participation in the CS regulation of 2008 was dropped when the regulation was revised on 2010. Removal of the chapter did not provide a blanket invitation to civil servants to be politically active as significant limitations were still in place through the code of conduct (Interviewee GO1). Nonetheless, opportunistic civil servants at times challenged the notion by participating in political activities during the parliamentary election campaign ${ }^{138}$ in early 2009, local council election campaign in early 2011, and on a number of other occasions such as a news conference conducted in mid-October 2011 by a group of senior officials at the Department of Penitentiary and Rehabilitation Services in which they defended their state minister (CSC, 2011b).

The 2008 constitution gave provision for all workers to strike, a right absent in the previous constitutions. Strikes were almost non-existent before the new constitution. With the newly-given right and the absence of any restrictions for civil servants, they too are increasingly participating in strike action. The first major strike, however, came prior to the ratification of the constitution. On July 1, 2008, teachers throughout the country went on strike demanding better pay and working conditions. The second round of strikes followed after the salary was increased for the entire CS

\footnotetext{
${ }^{138}$ An example is a civil servant from the N. Maalhendhoo Medical Centre participating in campaign (F. Ahmed, 2009a).
} 
from the start of 2009. In this instance, state attorneys, lecturers at the Faculty of Engineering Technology, and local doctors at the main government hospital went on strike in late February 2009 demanding greater pay rises.

The third round of major strikes occurred after the pay disputes between the CSC and the government in early 2010. Civil servants from several organisations went on strike in early February 2010, after the government refused to reinstate their original salaries. Among them were civil servants at the Attorney General's Office; Ministry of Tourism, Arts, and Culture; and Ministry of Fisheries and Agriculture. Furthermore, numerous petitions were signed by civil servants to either reinstate their original salaries or to reduce working hours to allow them to pursue secondary employment (Hamdhoon, 2010f).

\subsubsection{Society-driven politicisation.}

In Chapter Two (section 2.4.2), society-driven politicisation was defined as the influence from societal groups outside the CS who "lobby" or influence the decisionmaking process within the CS. As shown previously in this thesis (see sections 4.4.1, 4.4.2, 4.4.3, 4.4.4, 4.5.1), the newly-found democratic freedom by society has created a politically-charged atmosphere in which direct action in pursuit of political objectives in the form of petitions or public protests has become common. Civil servants as well as politicians have thus become targets of such direct action.

One strategy used by the island communities is to submit petitions to dismiss or transfer specific civil servants. Among such petitions include a petition signed by over 400 citizens of Lh. Naifaru Island in early July 2009 to dismiss the Imaam $^{139}$ of the main mosque in the island (Ashiya, 2009b), a petition in June 2010 by about 450 parents of a main school in the capital to stop the recruitment of a teacher who was accused of sex offences (A. A. Saeed, 2010), and a petition in January 2012 by about

\footnotetext{
${ }^{139}$ As mentioned in Chapter Five (section 5.2), a majority of the mosques in the Maldives are maintained by the government and almost all imaam are on the government payroll. Before the statutory CS, all imaam were government employees. Presently they are contracted staff of the CS, but are subject to different rules.
} 
100 parents of a school in the island of S. Hithadhoo urging the transfer of the principal (“Hithadhoo School Ge Principal," 2012).

Another strategy used in the islands is to forcefully close down office buildings when a group of citizens are unhappy with civil servants. In this regard, the school and island office in the island of AA. Ukulhahu was shut down by citizens in early February 2009 accusing the organisations of inadequate service (F. Ahmed, 2009b), and the island office of Sh. Foakaidhoo was shut down in the same month by citizens when the CSC refused to dismiss or transfer the Imaam of the island mosque (Ashiya, 2009c). Furthermore, during the pay dispute between the government and the CSC in early 2010, a group of ruling party activists entered the office of the CSC and intimidated the staff ("Video Footage Shows," 2010).

\subsubsection{Politician-driven politicisation.}

Although internal-driven and society-driven politicisation is present to some extent in the Maldives, the most significant mode - and the one that has the most impact on the CS model - is politician-driven politicisation. This section examines this type of politicisation in relation to the literature presented in Chapter Two (section 2.4.2).

\section{Modes of politicisation.}

A framework to assess this mode of politicisation was presented in Chapter Two (section 2.4.2). It focuses on the approach a new government chooses towards inherited senior officials and the field from which new appointments are made. This framework is used here, however, to assess the roots of the political appointees in the Maldivian ministries. A comparison is made here between the political appointees prior to the 2008 presidential election and after the new government came in. Table 7.1 provides the approximate percentage of changes in the most senior ranks of political appointments. 
Table 7.1: Modes of politicisation

\begin{tabular}{|l|c|c|c|c|}
\hline & $\begin{array}{c}\text { Non- } \\
\text { politicisation } \\
\text { (retained) }\end{array}$ & $\begin{array}{c}\text { Bounded } \\
\text { politicisation } \\
\text { (chosen from } \\
\text { existing } \\
\text { bureaucracy) }\end{array}$ & $\begin{array}{c}\text { Open } \\
\text { politicisation } \\
\text { (chosen from } \\
\text { outside the } \\
\text { public sector) }\end{array}$ & $\begin{array}{c}\text { Partisan } \\
\text { politicisation } \\
\text { (chosen based } \\
\text { on party } \\
\text { affiliation) }\end{array}$ \\
\hline $\begin{array}{l}\text { Presidential } \\
\text { advisers }\end{array}$ & - & - & - & $100 \%(5)$ \\
\hline Senior ministers & - & - & - & $100 \%(1)$ \\
\hline Ministers & - & $43 \%(24)$ & - & $67 \%(8)$ \\
\hline State ministers & - & $20 \%(16)$ & - & $57 \%(32)$ \\
\hline $\begin{array}{l}\text { Deputy } \\
\text { ministers }\end{array}$ & $4 \%(3)$ & & - & $76 \%(63)$ \\
\hline
\end{tabular}

Source: PO $(2008,2011)$

Note: The actual numbers are given in brackets.

As the above table shows, a majority of political appointees were replaced when the new government came to power. This was despite the retention of a number of officials from the previous government. The turnover in political posts shows that, in the Maldives, partisan politicisation is most common followed by bounded politicisation and a low degree of non-politicisation. The absence of recruiting outsiders from a non-political setting shows open politicisation is almost nonexistent.

\section{Thickening of government.}

As discussed in Chapter Two (section 2.4.2), thickening involves making political appointments into the ministerial bureaucracy. Thickening of government can be in the form of appointments for various oversight functions or to functions already carried out by civil servants. Such appointments can be a small fraction of the total state sector workforce, but in most cases they are a rather significant source of layering between elected officials and civil servants. This section examines thickening of government in the Maldives.

Article 115(f) of the constitution ratified in August 2008 grants to the president the power to appoint "officials necessary for the proper functioning of the duties of his office", considered a "blank cheque" (Interviewee GO6) to the president. As a result, immediately after the ratification of the constitution, President Gayoom issued a 
decree specifying the posts and organisations that he considered as necessary to fulfil his duties. In this regard, the most significant organisations removed from the purview of the CS were the PO and the presidential palace ${ }^{140}$ (Presidential Decree No. 2008/9), which contained a total of 247 and 295 employees ${ }^{141}$ respectively.

The change of government soon afterwards saw the use of this presidential power to a greater extent. Some even accused the Nasheed government of abusing this power (Interviewee FO10). Rather than confining his appointments through a decree that specified the organisations and posts that fell under article 115(f) of the constitution, President Nasheed continued appointing personnel to different organisations using the constitutional authority. One approach was to appoint personnel to the political cadre while the other approach was to appoint personnel to functions that the CS was carrying out. By using the latter approach, President Nasheed appointed an increasing number of staff to perform duties previously primarily carried out by civil servants. Such appointments include (1) advisers to the ministers, (2) co-ordinators to the provinces ${ }^{142}$, (3) co-ordinators to Male' city council, (4) a senior project director to one of the ministries (see section 6.8.2), (5) additional secretaries at the Ministry of Foreign Affairs, (6) a food security co-ordinator to one of the ministries, and (7) councillors. Such political appointees basically had the same job descriptions as civil servants (Interviewee FO10). Use of the first approach, vertical thickening, was also significantly greater in the Nasheed government compared to his predecessor. Table 7.2 shows a comparison of the highest ranked political appointees for the two governments.

\footnotetext{
${ }^{140}$ The PO is the highest public office in the Maldives and acts as the hub of the government. It oversees all government functions and advises the president accordingly. The presidential palace is the official residence of the president. During the reign of President Gayoom, the staff at the presidential palace increased significantly. In addition to staff for maintenance and housekeeping, a significant number of staff were hired for administrative tasks at the presidential palace. Such tasks included responding to letters sent to the president by the public and granting welfare assistance for those who seek assistance from the president. Often such functions were a duplication of the services provided by government ministries.

${ }^{141}$ Source: CSC (personal communication, March 21, 2012)

${ }^{142}$ The province was a concept introduced by the Nasheed government. During his reign the country was divided into seven provinces, with political appointees heading the provinces. After his resignation, the new government abolished the provinces.
} 
Table 7.2: Comparison of highest ranked political appointments

\begin{tabular}{|l|c|c|c|}
\hline & $\begin{array}{c}\text { Gayoom } \\
\text { government }\end{array}$ & $\begin{array}{c}\text { Nasheed } \\
\text { government }\end{array}$ & Percentage change \\
\hline Presidential advisers & 1 & 5 & $400 \%$ increase \\
\hline Senior ministers & 4 & 1 & $75 \%$ decrease \\
\hline Ministers & 24 & 14 & $42 \%$ decrease \\
\hline State ministers & 9 & 56 & $522 \%$ increase \\
\hline Deputy ministers & 43 & 82 & $91 \%$ increase \\
\hline TOTAL & $\mathbf{8 1}$ & $\mathbf{1 5 8}$ & $\mathbf{9 5 \%}$ increase \\
\hline
\end{tabular}

Source: PO (2008, 2011).

Note: Total number of ministers in Nasheed government was 14. In table 7.1, total number of ministers is given as 12 because two portfolios were vacant on May 5, 2011 - that date being when the list was derived.

\section{Pressure by political appointees on civil servants.}

The most evident manner of politicisation of the CS is through the direct pressures of political appointees on civil servants. Some aspects of this have been examined previously in this chapter. The focus in this section is on groups of specific civil servants who were in the direct path of political pressure and threats. Such an overview is presented because as soon as Nasheed's government came into power, political appointees were openly challenging the CSC as well as openly discrediting civil servants in political rallies (Interviewee FO6).

Threats by politicians have been evident at times when civil servants went on strike. In this regard, doctors and nurses were warned by leading officials of the ruling MDP when the doctors protested and nurses threatened to strike during the pay disputes in early 2009 (H. Mohamed, 2009).

Particular threats and pressure by political appointees were observed during campaigning for the parliamentary election of 2009. At times, councillors appointed by the president ordered civil servants to move to another island for the duration of the election. Such incidents were particularly seen in the islands of N. Landhoo (F. Ahmed, 2009c), Th. Thimarafushi and Th. Guraidhoo (Hamdhoon, 2009g). Furthermore, in a political rally during April 2009, Faafu atoll councillor threatened to dismiss a senior civil servant working in the council (Jameel, 2009). 
In some other instances, elected councils have refused to work with specific civil servants and issued motions in this regard. Such incidents were witnessed in the islands of Th. Thimarafushi ("Rashu Council Hingumah," 2011), V. Fulidhoo ("Fulidhoo Council Ge Civil Service," 2011), GDh. Thinadhoo ("Thinadhoo Katheebu Ge Eheetheriyaa," 2011), and Sh. Lhaimagu ("Lhaimagu Chief Suspended,” 2012).

At times, senior civil servants have also resigned due to political pressure. A case in point was the resignation of the Director General of the Environmental Protection Agency, who resigned in protest at political interference when a massive fine was imposed on a resort developer who was also running a TV station critical of the government ("Police Summon EPA Chief," 2011). Senior government officials confirmed the existence of such political interference in the daily operations of the CS (Interviewee GO5).

Such threats and pressure by political appointees and elected officials have been found, in most cases, to be contrary to the CS law. As a result, the CSC has often defended the civil servants and expressed concerns regarding the continuing politicisation of the CS. For example, press statements by the commission in early February 2009 and late April 2009 urged political leaders not to threaten civil servants (Hamdhoon, 2009h; CSC, 2009c). In some instances, the commission has also resorted to the courts in defence of specific civil servants. The most prominent case in this respect was regarding the deputy principle of GDh. Atoll Educational Centre who was suspended by the province office (Hamdhoon, 2009i).

\subsection{Civil service in an emerging democracy}

Civil services across the globe can show specific features and face challenges and obstacles irrespective of the extent to which democracy has matured and has been ingrained in the political culture of that particular nation. Emerging democracies are no exception in this respect. The path the CS has followed in the Maldives since gaining statutory status has been far from smooth. Such uneasiness can be attributed to the newness of both the CS and democracy and the lack of a common understanding of how to operate professionally in such a setting. This section 
examines three main aspects related to this: 1) the law-oriented approach of the CS; 2) de-institutionalisation of the CS; and 3) frequent amendments to the CS Act. An important point here is that these features and challenges are not necessarily evident only in emerging democracies. However, what is being witnessed in the Maldives is particularly due to the fact that the nation is an emerging democracy and due to the chosen model of the CS that is relatively independent of the political executive and is highly centralised.

\subsubsection{Law-oriented approach of the civil service.}

As evident from the previous two chapters, the centralised nature of administration prior to the establishment of the statutory CS has been preserved. The enactment of a law has predominantly been a nuance as far as the administration setup is concerned. The CS Act has been the legal base and the commission can formulate regulations governing different aspects of the CS. This legal authority has been used extensively by the CSC to regulate all aspects of the CS. Such a law-oriented approach has at times been the cause of rigidity and inflexibility in the operations of the CS (Interviewee GO6).

The previous chapter referred to several aspects of the CS regulation. An examination of the CS regulation shows the CSC's desire to regulate each and every aspect governing the CS. For instance, the first regulation published by the CSC in March 2008 had 19 chapters, which grew to 32 chapters within four years. While one might argue the importance of having all aspects regulated by a central agency to ensure uniformity, such detailed regulations and guidelines have at times been a hindrance to innovation and flexibility by the CS organisations as well as a cause for delays due to procedural guidelines.

Such extensive regulation and rigidity has often been a flashpoint when dealing with the government as well. In this regard, the interpretation of the Act by the commission was put to the test even prior to the full establishment of the CS. The CSC was adamant that all judges, except the judges at the High Court belong to the CS, while the government insisted that all judges irrespective of the title or the court were exempt from the CS. In March 2008, one of the commissioners said: 
We do not have to interpret the law. The Act mentions fandiyaaru. ${ }^{143}$ The constitution says fandiyaaru. It does not mention qaal'ee or magistrates. If they belong to the same group, why is there so much difference? Why didn't the law refer to fandiyaaru and others who do similar work? But the law says fandiyaaru and only the High Court has fandiyaaru. (A. A. Saeed, 2008, translation)

Eventually the commission backed down under intense pressure from the legal community. However, the commission enforced mandatory retirement on a number of presidential appointments in May 2008, insisting that the job title of such individuals were not listed in the exclusion list of the Act and thus they belonged to the CS. Such a literalist and pedantic interpretation by the commission has been controversial in a number of other instances, some of which have been highlighted previously in this chapter.

The letter-of-the-law approach has also put the commission in the spotlight when political pressure mounts. One such case was the attempt by the commission to appoint a qualified teacher to one of the main schools in the capital, a teacher who was accused of sexual misconduct but acquitted by the court. The school management, the school board, and parents were all against the appointment but the commission argued that there were no grounds for refusing his appointment as he was found not guilty by the court (A. A. Saeed, 2010). In another case, the commission was accused of reacting too slowly to take disciplinary measures against a senior civil servant in the island of Fuvahmulah who publicly discredited the president (Interviewee GO5). Furthermore, in a number of other cases, the commission has stood firm on certain civil servants with whom some island councils and atoll councils have refused to work. References to a number of such incidents were given previously in this chapter. Though the commission followed the set procedures on such matters, its alleged inflexibility has been criticised.

\footnotetext{
${ }^{143}$ In Dhivehi language the term fandiyaaru is commonly used for judges. Previously the term was also used as the official title of the chief justice (see section 5.2). For lower level judges, the term qaal'ee has been used. Under the present judicial hierarchy, judges at the Supreme Court and the High Court are called fandiyaaru, judges at the superior courts are called qaal'ee and judges at the island courts are called magistrates.
} 
The inflexibility has at times been directed at the civil servants as well. This occurs when civil servants are accused of shirking, sabotage, or using extra-procedural tactics to delay work. One interviewee described it as "tricks" in the bags of civil servants that are used to delay or block some of the government's policies (Interviewee PL2). As a senior government official indicated, at times civil servants object to policies forwarded by the political appointees on the basis that past administrative practices do not accommodate the implementation of such policies (Interviewee GO5). The official went on to add that administrative practices are "not written on stone" and civil servants are at times reluctant to change past behaviours and offer alternative solutions to their political masters (Interviewee GO5). As a result, civil servants are also found at fault due to their rigidity.

\subsubsection{De-institutionalisation of the civil service.}

As mentioned in Chapter Two (section 2.4.3), de-institutionalisation:

implies that existing institutional borders, identities, rules, and practices; descriptions, explanations, and justifications, and resources and powers are becoming more contested and possibly discontinued. New actors are mobilized. Outcomes are more uncertain, and it is necessary to use more incentives or coercion to make people follow prescribed rules and to sanction deviance. (Olsen, 2009, p. 10)

The short history of the statutory CS in the Maldives shows signs of various strategies being used to re-define the boundaries of the CS as well as attempts to arguably dismantle the CS using such approaches. All of these are directly related to the new-found democracy that the country has embraced. The following highlights each of the main approaches used in this respect.

\section{Changing the horizontal scope through legislation.}

The manner in which the horizontal scope is defined in the CS Act was discussed in the previous chapter (section 6.8.2). The employees of any organisation can be removed from the civil service by an Act of the majlis, and political leaders have 
used this approach in some instances to reduce its scope. Some officials believe that such fragmentation of the CS defeats the primary objective for the creation of the CS in the first place (Interviewee GO4). Table 7.3 shows the organisations removed from the CS in this manner.

Table 7.3: Organisations removed from civil service through legislation

\begin{tabular}{|l|l|c|l|l|}
\hline & \multicolumn{1}{|c|}{2008} & 2009 & 2010 & 2011 \\
\hline & Police (3120) & & Inland Revenue (39) & Customs (710) \\
\hline & $\begin{array}{l}\text { Police Integrity } \\
\text { Commission (9) }\end{array}$ & $\begin{array}{l}\text { University (447) } \\
(39)\end{array}$ & & \\
\hline & State Prosecutors (38) & & & \\
\hline & $\begin{array}{l}\text { Anti-Corruption Board } \\
(52)\end{array}$ & & & \\
\hline & $\begin{array}{l}\text { Judiciary (1053) } \\
\text { T311 }\end{array}$ & $\mathbf{0}$ & & $\mathbf{3 9}$ \\
\hline
\end{tabular}

Source: CSC (personal communication, March 21, 2012)

Note: Numbers of staff removed from the CS in brackets

Among the organisations mentioned in the above table, most organisations that were granted statutory status in 2008 were perceived by the lawmakers to be legal and quasi-legal authorities that should not be subject to direction by the president (refer to table 4.3). However, since the option to remove any organisation through legislation is available (see section 6.8.2), the possibility of using this strategy is always open. A case in point includes the omission of the Maldives Customs Service and the Maldives Civil Aviation Authority from the CS when their respective laws came into force in May 2011 and January 2012 respectively. As mentioned previously (see section 7.2.2), other organisations have also expressed their desire to choose this path due to what they perceive as the rigid rules of the CS. Furthermore, as the top appointments to most of such organisations are made by the president, the incentive for using this strategy is always present. 


\section{Changing the horizontal scope by corporatisation.}

Corporatisation of the CS organisations was one of the main approaches used by the Nasheed government in order to curb the CS. Table 7.4 shows the organisations and the number of civil servants removed by this approach.

Table 7.4: Organisations removed from civil service through corporatisation

\begin{tabular}{|l|l|l|l|}
\hline & \multicolumn{1}{|c|}{2009} & \multicolumn{1}{|c|}{2010} & \multicolumn{1}{|c|}{2011} \\
\hline & State Radio (261) & Hospitals (1523) & Hospitals (2935) \\
\hline & State TV (218) & Regional Airports (149) & Tourism Promotion (15) \\
\hline & Construction (58) & & Regional Airports (119) \\
\hline TOTAL & $\mathbf{5 3 7}$ & $\mathbf{1 6 7 2}$ & $\mathbf{3 0 6 9}$ \\
\hline
\end{tabular}

Source: CSC (personal communication, March 21, 2012)

Note: Numbers of staff removed from the CS in brackets.

The government retained all the shares after the above-mentioned organisations were converted to corporations. The boards of directors of all those corporations were appointed by the government and have full authority for personnel management within the corporation. As a result, both redundancies and appointments based on political affiliations have been witnessed on a number of occasions. Accusations have been directed at the government of using such strategies to force employees to work "at the mercy of political appointees" (Interviewee FO10). A common conception is that, after such employees are removed from the protection offered by the CS Act, at times they have been threatened with dismissal if they refuse to join the ruling party (Interviewee FO1).

\section{Decentralisation of tasks in the capital to outer islands.}

One of the most controversial approaches used by the Nasheed government was the decentralisation of a number of the CS functions formerly delivered in the capital to the islands by moving some services to islands along with the civil servants providing them. The objective of this decentralisation was to strengthen the elected city, atoll, and island councils (see section 4.3.3) and deliver services closer to the 
people - a significant shift from past practices where central ministries controlled all aspects of administration (see section 5.4.4).

Some interviewees argued that the government's decentralisation policy was an attempt to make a number of civil servants redundant (Interviewees CV1, FO7). They argued that the government was aware of the difficulties such civil servants would face moving to other islands without additional benefits. One of the biggest decentralisation initiatives was in early January 2009 when the Ministry of Home Affairs sent an application to the CSC to make about 1000 civil servants redundant (Hamdhoon, 2009j), though the ministry later insisted that they were simply restructuring to provide services at the province level (F. Ahmed, 2009d, 2009e). Although most of the redundant civil servants were eventually offered other CS jobs in the capital Male', the desire by the political masters to restructure was perceived by some civil servants as a direct attempt to politicise the CS.

Figure 7.1: Civil servants working in Male' and atolls

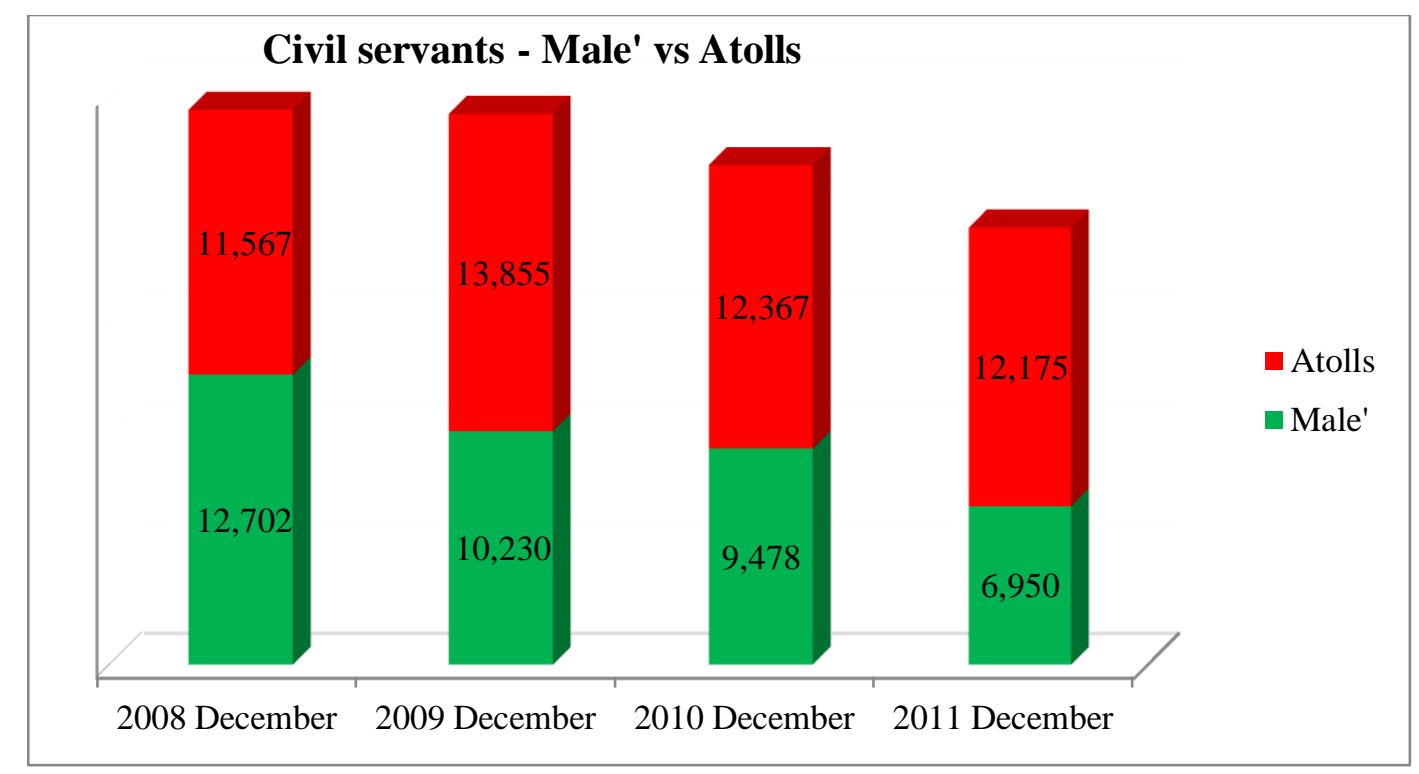

Source: CSC (personal communication, August 27, 2012); DNP (2010, 2011)

Despite the controversies surrounding the attempts to decentralise, as shown in figure 7.1, the Nasheed government gained significant success in shifting the balance of the number of civil servants working in Male' and the atolls. Such a shift can be considered important in the efforts towards decentralisation. 


\section{Higher salaries at other statutory organisations.}

Democratic reform that established numerous statutory bodies has also brought fragmentation to the state sector. As each individual statutory body has the legal right to set the salaries for its staff, significant differences have emerged. The CS is the biggest employer in the state sector. However, other independent bodies in most cases set their staff salaries relatively higher than the CS salaries. Table 7.5 shows a total salary comparison made by Haveeru Daily where similar designations in different organisations were compared to that of the CS for the year 2009.

Table 7.5: Total salary comparison between civil service and selected other organisations

\begin{tabular}{|c|c|c|c|c|}
\hline Designation & Organisation & $\begin{array}{c}\text { Salary } \\
\text { (in MVR) }\end{array}$ & $\begin{array}{l}\text { The CS } \\
\text { salary (in } \\
\text { MVR) }\end{array}$ & $\begin{array}{l}\text { Salary gap } \\
\text { (in MVR) }\end{array}$ \\
\hline $\begin{array}{l}\text { Deputy Director } \\
\text { General, } \\
\text { Investigation }\end{array}$ & $\begin{array}{l}\text { Anti-Corruption } \\
\text { Commission }\end{array}$ & 26,700 & 14,400 & 12,300 \\
\hline Executive Director & Elections Commission & 25,706 & 17,560 & 8146 \\
\hline $\begin{array}{l}\text { Assistant Director } \\
\text { General }\end{array}$ & $\begin{array}{l}\text { Prosecutor General's } \\
\text { Office }\end{array}$ & 19,635 & 13,065 & 6570 \\
\hline Director & $\begin{array}{l}\text { Dept. of Judicial } \\
\text { Administration }\end{array}$ & $17,652.50$ & 10,835 & 6817.50 \\
\hline Senior Officer & $\begin{array}{ll}\text { Police } & \text { Integrity } \\
\text { Commission } & \end{array}$ & $10,134.50$ & 7610 & 2524.50 \\
\hline $\begin{array}{l}\text { Administrative } \\
\text { Officer }\end{array}$ & $\begin{array}{ll}\text { Police } & \text { Integrity } \\
\text { Commission } & \end{array}$ & 7974.65 & 5965 & 2009.65 \\
\hline IT Officer & Elections Commission & 9357 & 6520 & 2837 \\
\hline Labourer & $\begin{array}{l}\text { Prosecutor General's } \\
\text { Office }\end{array}$ & 5819 & 4100 & 1719 \\
\hline
\end{tabular}

Source: A. Saeed (2010)

These and similar discrepancies between the salaries of the CS jobs and similar jobs in other state organisations have become a significant issue that has resulted in the exodus of professional civil servants to places that offer better salaries (Interviewee 
GO6). In addition to statutory bodies, the growing number of SOEs has also attracted professional civil servants. In reference to this issue, the chairperson of the CSC said:

Technical and professional staff in civil service is moving to SOEs [and other statutory bodies] because they offer better pay compared to civil service. For example, the former Department of Inland Revenue was changed to an independent organisation in the name of Maldives Inland Revenue Authority. After they changed their legal status, they offer much higher salaries. As a result, professionals in the finance field are moving there. (Hamdhoon, 2010g, translation)

Several countries have followed similar paths in making similar authorities, such as the tax authority, independent organisations, mainly to clean out corruption and attract and retain competent professionals such as accountants who would otherwise have to take a significant cut in income to become civil servants. In the Maldives, as the CS offers the lowest salaries within the state sector, it often loses out in competition for limited supply of qualified professionals. Expressing his concerns about this exodus from the CS, the chairperson of the CSC indicated that they were not able to fill vacancies even at the director's level (Hamdhoon, 2010g), which is a senior position in the organisation (see figure 6.2).

\section{Political appointees' role ambiguity.}

Before the CS Act, the minister was in charge of all aspects of the organisation, including personnel management. As one interviewee stated, at that time the minister was the political and the administrative head of the organisation (Interviewee PL2). In other words, the distinction between politics and administration was almost nonexistent prior to the formation of the statutory CS. The introduction of a CS that was solely focused on administration and delivering the policies of the government of the day undoubtedly required a shift in mentality on the part of both civil servants and political appointees. 
A clear demarcation between the CS and politics is probably an elusive goal (refer to section 2.4.1). The objective for establishing a distinction between the CS and politics thus relies mostly on relative terms. However, the fairly quick speed at which the Maldives embraced democracy did not provide adequate time for political figures to assimilate into this new system of governance where politicians focus primarily on policy and civil servants focus primarily on implementation. A "learning period, adjustment period, transitional period, [and an] acceptance period" (Interviewee GO4) is required to achieve that.

The inability of the political appointees to adapt to the new relatively demarcated role was evident from the early stages. A senior government official summarises the picture as follows:

They don't know what to do. They don't know what their roles are. So they come and try to do the same thing the permanent secretary does. They tell people what to do, take over certain sections, try to manage things. They do exactly the same things that civil servants do. They perform the same tasks as civil servants do. (Interviewee GO5)

As stated earlier, the lack of relative clarity on the appropriate role of political appointees can also be attributed to the young democracy in the Maldives. Firstly, the old ways in which the ministers run all aspects of the organisation have not yet been fully replaced (Interviewees GO5, GO6). Secondly, the newly established multi-party system brings to the CS organisations politicians who are at times totally new to the public sector (Interviewees CV1, FO3, FO4, FO7, FO8, GO6). Thirdly some political appointees claim they have the required technical expertise and thus reject the CS (Interviewee GO5). Fourthly, some technical experts were elevated to political positions but continued their technical role rather than shifting to a political role (Interviewee GO5). Due to such practices that are predominantly due to the novelty aspect of democracy, considerable time is required to have a harmonious system in place (Interviewees FO4, GO3, PL2). Nonetheless, the boundary between the roles may always be permeable and contested, although a distinction remains. 


\subsubsection{Frequent amendments to the Civil Service Act.}

The CS Act is a relatively new piece of legislation in Maldivian legislative history. Nonetheless, it has seen one of the highest numbers of amendments proposed to any law. A number of successful and unsuccessful attempts have been made to amend the CS Act in the past few years. Most such amendment bills have been driven by the political power play between the contending factions in the parliament. Although the proposed amendments - passed, failed, or pending - were not intended to alter the basic principles of the CS, they affect its stability. The following outlines the CS amendment bills, their objectives, and the outcomes.

In a letter sent by the PO to the relevant minister on January 22, 2008, a directive was given to submit a CS bill that included provisions to: delay mandatory retirement by one year; remove the provision given to the CSC to retire civil servants at the age of 55 and give that choice to the civil servants themselves; reduce the time for servants to resign before standing for public office from six months prior to election date to ten days after the election date is announced; narrow the meaning of political participation for civil servants; and include a provision for consultation with the political head of the organisation prior to the appointment of permanent secretaries (PO Letter, 2008). Government submitted an amendment bill to the majlis on March 3, 2010 - a bill that was wider in context than the directives of the PO. Additions in the bill included: narrowing the scope of the CS by excluding a significant number ${ }^{144}$ of staff from the CS; provision for a civil servant to return to his/her previous job after serving in a political post appointed by the president; and allowing those MPs who have been working also in the CS at the inception of the CS to retain both their jobs until they resign or the parliamentary term expires (Civil Service Amendment Bill, 2008a). The CS was to become operational at the beginning of May 2008 and this bill turned out to be very controversial. Opposition MPs argued that the bill proved the insincerity of the government about establishing a statutory CS.

\footnotetext{
${ }^{144}$ During the parliamentary debates on April 1, 2008, Minister of Legal Reform, Information and Arts revealed that an additional 5622 staff would be excluded from the CS if the amendment were passed (Nasheed, 2008b).
} 
The second reading of the bill proceeded on March 17, 2008. During the submission of the bill, Minister of Legal Reform, Information and Arts, Mohamed Nasheed ${ }^{145}$ focused on two main points - re-adjustment of the bill to suit a presidential form of government, and to provide a buffer for about 1700 employees who would be forced to retire when the CS was fully established at the start of May 2008 (Nasheed, 2008c). The parliamentary debate that followed was predominantly fiercely against the proposed amendments. Among the many MPs opposed to such amendments, Ahmed Nazim who was the sponsor of the CS bill, said "when the time has come to implement the Civil Service Act and when [the government] acts in this manner, it shows the lack of good faith" (Nazim, 2008, translation). He went on to state that the rationale presented by the government was invalid and accused the government of failing to attend to the retirement issue since the passing of the bill in April 2007 (Nazim, 2008). As the constitutional assembly was nearing the completion of the constitution and a presidential election was looming, support for rejecting the bill was strong despite some valid and necessary changes ${ }^{146}$ that were proposed in it. After three days of spirited, passionate, and rhetorical debating by opposition and government-aligned MPs, voting on the bill took place on April 1, 2008. After a number of government-aligned MPs, citing conflict of interest, abstained from voting, the bill failed by a slim margin of two votes. The result was perceived as a victory for the opposition after it ran a strong campaign against the bill in the media.

After the disappointing outcome for the government, the following day it announced that it would submit another amendment bill that aimed to establish a number of different independent organisations that were not part of the CS (Moosa, 2008b). The government aimed to re-formulate the structure of the previous amendments by proposing several independent organisations such as a judicial administration commission, police commission, and a parliamentary service. This strategy was deployed because opposition MPs accused the government of removing those

\footnotetext{
${ }^{145}$ As mentioned previously (section 7.2.1), he served as a minister in the Gayoom government. He is not the former president who has the same name.

${ }^{146}$ Among the sectors and posts that the government proposed to add to the exclusion list of CS were state ministers, advisers to the president, state dignitaries, political advisers and secretaries of ministers, island chiefs, staff of the PO and presidential palace, police service, judiciary, parliamentary service, elections commission, and anti-corruption board. These posts and organisations were eventually removed from the purview of the CS after the 2008 constitution and the subsequent laws came into force.
} 
services from the CS to keep them under the authority of the president. Nonetheless, the bill never made it to the parliament as the government was once again preoccupied with the rapid political changes underway during that period.

Soon after, on May 1, 2008, the Maldivian CS was established and became fully operational. Immediately, 1714 government employees were retired by the CSC (Hamdhoon, 2008e). The government had therefore failed in its previous attempts to delay the retirement. Regardless of the political setback, on June 9, 2008 government once again submitted a CS amendment bill to the parliament. However, this bill did not include any of the controversial topics that were included previously. Rather the only element covered in the bill was to provide a choice for the retirees to choose either to receive full salary for an extra two years or an alternative benefit package formulated by the CSC (Civil Service Amendment Bill, 2008b). The first reading of the bill was held on June 9, 2008. In the charged political atmosphere of that period, there was no lack of political rhetoric during the debate on this bill as well. One MP even condemned the PSD for its lack of vision and its failure to propose all the required changes to the original CS bill during its long route in the parliament (Adam, 2008). Nonetheless, the bill went through the parliamentary process smoothly and was passed comfortably on July 21, 2008. Upon ratification by the president, the bill became law on August 5, 2008.

One more amendment bill that was politically significant was submitted before the end of 2008. It was presented by Aneesa Ahmed, MP from Mulaku Atoll. The bill aimed to change article 51(a) of the CS Act which focused on resignation of civil servants contesting for public elections. The rationale for submitting the bill was that the current six months period stipulated in the Act was not practical as most elections, especially bi-elections, were announced much closer to the election dates, and so the six months period should be changed to a maximum of three days from the date the election was announced (Civil Service Amendment Bill, 2008c). Parliamentary debate on the bill commenced on November 26, 2008, after the presidential election which were held the previous month. With the new government in place, the composition of the parliament also changed as the newly-elected 
president replaced the eight MPs who had been appointed ${ }^{147}$ by the outgoing president. As a result, the new government had a comfortable majority in the parliament which it used to reject the bill on February 23, 2009. As discussed earlier in this chapter (see sections 7.2.1, 7.2.2, 7.3.3), the perception of the CS among the newly-elected government was not favourable and so MPs aligned with the government were eager to show a negative image of the civil servants and in the meantime vowing to "clean" the CS from the influences of the previous regime (Afeef, 2008, 2009).

The next amendment bill was considered most significant in terms of re-designing an element of the CS model. It was submitted by Ibrahim Muhtholib, MP from Faresmaathodaa. The bill aimed to shift on the parliament the responsibilities of the president in appointing and dismissing the CS commissioners. As the commissioners had to be re-appointed prior to the end of the constitutional interim period (August 7, 2010), both sides of the political divide were eager to gain the upper hand in the appointment process. The first reading of the bill was held on October 20, 2009. An opposition coalition had the majority in the majlis during that period. The debates were split along party lines as the MPs aligned with the government advocated keeping the current setup while opposition MPs wanted control brought to the majlis where they had the majority. According to opposition MPs, the proposed amendments were necessary to de-politicise the CS from the government's influences thereby making it a fully independent institution (Maniku, 2009). On the other hand, MPs supporting the government repeatedly accused the proposed amendment of being against the principles of the presidential form of government that the nation had embraced (Easa, 2009). MPs aligned with the ruling MDP made passionate pleas not to use the parliamentary majority to gather powers towards the parliament by what they considered was an amendment against the constitution and presidentialism. Nevertheless, on June 21, 2010, the opposition-controlled majlis comfortably passed the second CS amendment bill. The bill was then vetoed by President Nasheed but went back to the majlis and on July 14, 2010, was passed once again with a full majority of the majlis, overriding the presidential veto.

\footnotetext{
147 Though the new constitution was ratified in August 2008, the parliament that was elected under the previous constitution remained until the new parliament was elected under the new constitution.
} 
Consequently the constitution required the president to give his assent and the bill eventually became law on July 21, 2010.

By February 2012, three more amendment bills had been submitted and were at different stages of the parliamentary process. Those bills were submitted by Abdul Raheem Abdulla, MP from Fonadhoo dhaairaa on November 17, 2009; Moosa Maniku, MP from Hulhuhenveyru dhaairaa on October 26, 2010; and Ibrahim Latheef, MP from Hithadhoo dhekunu dhaairaa on September 4, 2011. The first bill focused on detailing the benefits for civil servants who were made redundant through restructuring. The second bill was an attempt to repeal the second amendment to the CS Act that removed the president's powers in appointing and dismissing the commissioners. The more contentious bill appeared to be the third one, which removed all the barriers to running for political office for both commissioners and civil servants: candidates would not need to resign though they would have to leave if elected. During the parliamentary debates, some MPs expressed concern that the amendment would effectively remove the professionalism of civil servants and dismantle the whole concept of the CS (Waheed, 2011). This bill failed at the first parliamentary reading on June 6, 2012.

The most comprehensive amendments proposed to the CS Act have been from the CSC. According to article 74 of the CS Act, the commission is obliged to submit a report along with proposed amendments to the Act after one year of full implementation. Although the commission sent a detailed amendment bill to the parliament, it did not reach the floor of parliament due to the fact that a MP is required to submit bills to the floor. ${ }^{148}$ The changes proposed by the commission did not include any changes to the principles of the CS or the CS model. Proposed amendments included removing contradictions within the Act and contradictions between the CS Act and the Employment Act, providing greater clarity on a number of aspects such as political participation and the responsibilities of permanent secretaries, aligning a number of articles with the 2008 constitution, providing

\footnotetext{
${ }^{148}$ All bills are required to be submitted by a MP, either affiliated with the government or opposition. Under the current parliamentary regulations, unfortunately no mechanism exists in which amendments proposed by statutory organisations can be submitted to the parliament floor. Government is often reluctant to submit such bills through the ruling party MPs.
} 
greater protection for civil servants when restructuring, and provision for the CSC to make changes to the CS needed to accommodate the policies ${ }^{149}$ of the government of the day (Civil Service Amendment Bill, 2009).

\subsection{Conclusion}

This chapter focuses mainly on the primary research question ${ }^{150}$ of the thesis. It examines the impact the CS model has on the democratisation process and conversely the impact of the democratisation process on the CS model of the Maldives. The chapter also examines the Maldivian CS in the context of an emerging democracy.

The Maldivian experience shows that, on the positive side, the ills of the past where personnel management was driven by political patronage have been put to rest (Interviewee FO3). The CS is incrementally developing into a professional body. Nonetheless, the democratic polity appears to progress at a slower pace. The nascency of democracy in the Maldives has created a politically-charged environment where political rationality dominates. As the CS and democracy operate in the same domain, the domination by politics of the CS has at times proven to have an adverse effect on the attempt to create a professional CS. Therefore, democratic maturity is paramount to establish a fruitful link between the two processes so that the CS and democracy can go hand-in-hand in the intended manner.

The chapter also shows that one of the reasons for the current anomalies in the interaction between the CS and democracy is the independent model of the CS chosen in the Maldives. The detachment of the CS from the control of the political executive has been found particularly troubling when the implementation of different aspects of the CS is considered. As a result, the political executive devises numerous strategies in its attempt to limit the role of or bypass the CS by "thickening" or moving functions out of the CS into SOEs.

\footnotetext{
${ }^{149}$ For instance, public-private partnerships.

${ }^{150}$ What effects has the current model of CS had on the democratisation process and vice versa?
} 
The statutory CS inherited a centralised administrative model. The decision to continue with such centralised administrative practices did not complement the decentralised political model. The political leaders perceived this incompatibility as an inflexibility of the CS, resulting in further politicisation of the CS.

The next chapter provides an overall conclusion to the thesis. 


\section{CHAPTER 8: CONCLUSION}

\subsection{Introduction}

The primary purpose of this study has been to analyse a case of the development of a CS model as part of a process of democratisation in the Maldives. A secondary purpose was to examine how the process of democratisation and choice of the CS model was different because the Maldives was a small-island state. The theoretical framework used to operationalise these objectives was centered on the concepts of civil service, democratisation, and small-island states. Although these concepts are discussed widely in the contemporary literature, they have not as yet been presented in an integrated manner and this thesis attempted to fill this gap. By examining the case of the Maldives, this gap was addressed by:

a) Describing the CS model of the Maldives in relation to the options available for its development;

b) Analysing the process by which the political actors in the Maldives arrived at the current model of CS during the transition to a multi-party democracy and the reasons for the choices they made;

c) Analysing the interaction between the political executive and the CS in the context of developing new democratic institutions in the Maldives; and

d) Describing the features of the Maldivian economy and society that seems specific to relatively small and isolated countries and assess whether such features had influenced the democratisation process and the decisions on the choice of the CS model in the Maldives.

Rather than presenting a summary of the previous chapters, this chapter provides an overall conclusion of the thesis. This chapter is divided into four parts: main research findings based on the research propositions; contribution to the literature; lessons for the Maldivian CS; and implications for future research. 


\subsection{Main research findings}

1. The development of a new CS model and negotiation of a CS Act were part of the democratisation process between 2005 and 2008 but were clearly in the hands of political elites and involved no wider public participation at all; To that extent the process fitted Welzel's model of mass responsive democratisation and Huntington's transplacement model: that while mass protests and other expressions of opinion are important in triggering democratisation processes, these processes are at some stage moved forward by negotiation or consensus within or between elites.

2. The CS Act that emerged was a mix of pre-existing codes of practice which had some specifically Maldivian elements but drew on other regional administrative codes, together with borrowings based on research into the current CS laws of other countries. But the result was a law which was founded on some principles commonly described as "Weberian" but adapted to the Maldivian circumstances.

3. The choices that the lawmakers made regarding the CS model were motivated by a number of different considerations. The first was the dominant agenda of securing a politically neutral CS largely insulated from the direct patronage of the political executive. This was a result of a wider elite negotiation on the future extent of executive power. The issue in drafting that turned out to be most important was setting the boundary between the political arm and administrative arm of the executive. The second point was that many detailed provisions that were not relevant to the dominant agenda were carried over from previous Maldivian codes or drawn from the codes of other jurisdictions, in either case with little debate.

4. Transition to democracy is not complete in the Maldives. The process is still relatively unstable and fragile. In particular, although the CS is now more firmly founded in law and there is less scope for arbitrary political intervention, there is a continuing contest between the political arm and the administrative arm of the executive over the boundaries between them. This ongoing contest continues to be critical for the prospects of stable democratisation. 
5. Islandness and smallness did not have a major direct bearing on the process of democratisation in the Maldives. However, islandness was to some extent a factor in the design of the constitutional architecture. Furthermore, smallness and social cohesiveness is presently not enough to counter the growing polarisation of society which may constitute a threat to the stability of this fragile emerging democracy. The Maldives being a small-island state did not have a significant impact on the choice of the CS model. Nonetheless, the social closeness of the small Maldivian society may inhibit the separation of public and private life that is important for institutionalising a professional CS.

\subsection{Contribution to the literature}

This research has examined the path the Maldives underwent and the influences evident in the development of the CS as a public institution. It is arguable that smallisland states share some similar significant characteristics that may influence the formation of public institutions such as the CS, and consequently the relationships between that institution and other institutions of the state in a democracy. This section outlines possible characteristics in this respect that were evident from the Maldivian case.

The democratisation process witnessed in the Maldives has similarities to that of other nations. A combination of longer-term changes in Maldivian society and economy underlie the process and some significant political events triggered its acceleration. Similarly, reform of state administration has been one of the components of the reform agenda. Although there are features of public administration evident in small-island states such as the greater difficulty of separating public and private life that may potentially deter a professional CS, they have not so far been a major hindrance to establishing a politically neutral CS. However, attempts to politicise the CS, initiated mainly by the political executive, have been a countervailing influence. This is compounded by a lack of a legally clear linkage between the CS and the political executive. 
Establishment of a statutory CS that is relatively detached from the political executive has been a deliberate act by the policy makers of the Maldives. One of the reasons for choosing such a model has been to disallow past practices of patronage appointments used by the president. However, this focus on trimming the powers of the political executive in a small society where politics are played out at a personal level, rather than focusing on building an efficient CS, has probably contributed to the ongoing instability of relationships between the CS and political executive.

The retention of the existing centralised administrative system in the new statutory CS has been a convenient option for policy makers of the Maldives, and was mainly a consequence of the lack of attention to substantial issues of efficiency and effectiveness in the CS model together with a greater focus on other democratic reforms. A decentralised mode of administration would have been a better fit for an archipelagic nation which initiated democratic reforms that included political decentralisation.

\subsection{Lessons for the Maldivian civil service}

This section examines the possible lessons for the Maldivian CS that may be needed to embed the values of a stable career CS based on a principle of neutral competence in the Maldivian polity.

The Maldives presently lacks a modern general legal administrative environment with the degree of legal certainty required to increase predictability and reduce arbitrariness within the CS. This is consistent with Cardona (2001, p. 6), who states that, "in order to complete the administrative system, other actions, apart from drafting the civil service law, are also important and should be carried out either simultaneously or immediately after the enactment of the Law on Civil Service". Cardona (2001) has identified two pieces of legislation, absent in the Maldives, required to complete the legal administrative framework: a general law on administrative procedures and a law regulating administrative processes.

A law on administrative procedures is needed to enable "the civil service and, in general, public institutions to operate under clear rules in their relationships among 
themselves and with the public at large" (Cardona, 2001, p. 6). On the other hand a law regulating administrative processes is needed to provide clear "ways and means for the judicial review of administrative actions and decisions to operate" (Cardona, 2001, p. 6).

Reference has been made in this thesis to two laws that contribute to the material scope of the CS: Official Kanthah [Issues] Chapter 1 (law no. 1/68) that grants presidential powers on setting the mandate of government organisations and the general responsibilities of government employees, and Official Kanthah [Issues] Chapter 2 (law no. 2/68) that covers the procedures for writing official letters and reports. Both these laws are insufficient and do not fulfil the challenges in the present day environment. For instance, some provisions, such as the rules for official correspondence seem excessively prescriptive and references to the general code of conduct overlap and conflict with the CS Act.

A weakness in the CS Act is the CSC's dual role of not only regulating the CS, including staff conduct, but also investigating staff grievances. As mentioned (section 6.4.1), the lawmakers opted to maintain both roles within the commission. Retention of these roles within the CSC can create conflict of interest. Additionally, it can remove the "independent" factor when investigating grievances directly related to the CS, although provision for appeal beyond the CSC is available. A legal review of the roles of the commission is thus needed. Furthermore, establishment of an Ombudsman, currently not present in the Maldives, may need to be considered (Interviewee FO5).

Another potential area for improvement is the provision for greater legal protection against arbitrary dismissal of civil servants in particular. With changes of government likely to be a normal feature of the new democracy, as discussed in this thesis, newly-elected governments can use different measures in order to resize the $\mathrm{CS}$ as well as removing organisations out of the CS thereby removing the legal protection of the CS Act. Although both the CS Act and the Employment Act provide appeal mechanisms, substantial legal protection prior to any changes (such as resizing and restructuring) is presently lacking in both Acts. 


\subsection{Implications for future research}

This study examined the development of a statutory CS in the Maldives and outlined the effects the model and the democratisation process had on each other. The literature on the main concepts of civil service, democratisation, and small-island states and the research framework developed from this scholarship has proved to be a useful object of this case study and should be useful for other case studies with similar objects.

Small-island states are more likely to share common features than with other states on matters of political development. As a result, further studies of similar processes of political and the CS reform in other small-island states using the framework developed in this research can add to the exemplary knowledge from this research and lead to a stronger generalisation for other small-island states.

This study was undertaken only a few years after the governance reform that included the introduction of a multi-party democracy and a new statutory CS. Reexamination of the effects that democratisation and the CS have had on each other after consecutive changes of government in the future, can also help to reveal the extent of institutionalisation of the reforms in the Maldives.

\subsection{Conclusion}

The Maldives is an emerging democracy. The continuous challenges the state institutions are facing are evident. Inception of a new statutory CS in such an environment has so far revealed mixed results. This case study is appropriately confined to a particular phase in the history of the Maldives and is a window on some stages of a process of democratisation that, from subsequent events, clearly has an uncertain future. But it casts light on how one small country sought to institutionalise its citizens' expressed desires for democracy and therefore, perhaps, what will be some important conditions for its future consolidation. 


\section{Coda to the research}

This thesis covers events up until March 2012. There is a brief epilogue of events from then until June 2013 when this thesis was deposited. Following the disputed resignation of President Nasheed, his Vice-President, Dr. Mohamed Waheed Hassan Maniku assumed power. Dr. Waheed's government is a coalition that includes all the major political parties that opposed Nasheed.

A commission of national inquiry was established to investigate the legality of President Nasheed's resignation. The commission was backed by the Commonwealth. The commission published its report on August 30, 2012. The main findings of the report were: 1) The change of President in the Republic of Maldives on 7 February 2012 was legal and constitutional; 2) The events that occurred on 6 and 7 February 2012 were, in large measure, reactions to the actions of President Nasheed; 3) The resignation of President Nasheed was voluntary and of his own free will. It was not caused by any illegal coercion or intimidation; and, 4) There were acts of police brutality on 6, 7 and 8 February 2012 that must be investigated and pursued further by the relevant authorities (Commission of National Inquiry, 2012, p. 2).

The prosecutor general charged Nasheed with the unlawful arrest of the judge which sparked the events that eventually led to his resignation. Initially, Nasheed refused to attend the court hearings - leading the court to issue an arrest warrant for Nasheed. In the face of imminent arrest in February 2013, Nasheed sought refuge in the Indian High Commission in Male' where he stayed for 11 days. Refusal to attend court once again led to another arrest warrant, which was carried out in March 2013. Nasheed was released after the court hearing. The court case is still on-going but is boiled down with pre-trial procedural matters. It is unlikely that the trial will begin before the presidential election set for September 2013 in which Nasheed is also expected to compete. 


\section{Reference list}

Aadel, L. (2001). Essential issues of politico-administrative relations. Public Management Forum, VII(1), 7-11.

Aberbach, J. (1990). Keeping a watchful eye. Washington, DC: Brookings Institute.

Aberbach, J. A., Putnam, R. D., \& Rockman, B. A. (1981). Bureaucrats and politicians in western democracies. Cambridge, MA: Harvard University Press.

Aberbach, J. D., \& Rockman, B. A. (1987). Comparative administration. Methods, muddles, and models. Administration Society, 18(4), 473-506.

Aberbach, J. D., \& Rockman, B. A. (1988). Image IV revisited: Executive and political roles. Governance: An International Journal of Policy and Administration, 1(1), 1-25.

Adam, J. I. (2008, July 1). Civil service amendment bill. Maldives parliamentary debates.

Aeberhard, J. H. (2001). Comparative study of contents of civil service statues (Department for Government and Labour Law and Administration document No. 5). Geneva: International Labour Office.

Afeef, H. (2005, November 14). Civil service bill. Maldives parliamentary debates.

Afeef, H. (2008, December 4). Civil service amendment bill. Maldives parliamentary debates.

Afeef, H. (2009, February 23). Civil service amendment bill. Maldives parliamentary debates.

Ahmad, R. A. (2001). The state and national foundation in the Maldives. Cultural Dynamics, 13(3), 293-315.

Ahmed, A. (2005, November 14). Civil service bill. Maldives parliamentary debates.

Ahmed, F. (2008, November 18). Inthihaabuge dhevana burugai siyaasee harakaath thakugai baiverivi haiy muwazzafakaa dhekolhah fiyavalhu alhaifi [Seven employees have been disciplined who were politically active in the second round of the presidential election]. Haveeru Daily. Retrieved from http://www.haveeru.com.mv

Ahmed, F. (2009a, April 4). Siyaasee harakaathehgai baiverivi maalhendhoo si'hee marukazuge muwazzafakah ekan nukureveyne kamah bune bayaan nagaifi [An employee of the Maalhendhoo Island Health Centre who were involved in a political activity has been reprimanded]. Haveeru Daily. Retrieved from http://www.haveeru.com.mv 
Ahmed, F. (2009b, February 4). Ukulhahu rayyithun nukume rashu ofeehaai court aai school bandhu koffi [Citizen of the Ukulhahu Island has in protest closed down the island office, court, and school]. Haveeru Daily. Retrieved from http://www.haveeru.com.mv

Ahmed, F. (2009c, May 5). Landhoo bodu katheebu rashugai huregen MDP ah vote nulibeyne kamah adu fethurumun eynaa vaguthee gothun atholhu ofeehah badhalhuvaan angaifi [Senior Katheebu of the Landhoo Island has been temporarily transferred to the atoll office when rumours spread that MDP cannot prevail in the election if he remains]. Haveeru Daily. Retrieved from http://www.haveeru.com.mv

Ahmed, F. (2009d, January 18). Province thah ufahdhanee male' in liben hunna khidmaiy thah rashaa kairi sarahahdhakun foaru kohdhinumah: Secretary [Provinces are being established to provide the services available in Male' from close proximity of the islands: Secretary]. Haveeru Daily. Retrieved from http://www.haveeru.com.mv

Ahmed, F. (2009e, January 18). Haaheh haa muwazzafun vaki kurumah civil service commission gai edhifaeh no-onnaane: Secretary [No request was sent to the civil service commission to make around a thousand civil servants redundant: Secretary]. Haveeru Daily. Retrieved from http://www.haveeru.com.mv

Ahmed, F. (2011, April 19). Party thakun vaki vumah anna mahun feshigen hushahalhan jeheynee e party akah: Elections [Effective next month, request to withdraw from a political party should be sent to the respective party: Elections]. Haveeru Daily. Retrieved from http://www.haveeru.com.mv

Alam, M., \& Jasimuddin, M. (Eds.) (2006). The public service of the Republic of Maldives - a profile. Current good practices and new developments in public service management. London: Commonwealth Secretariat.

Anckar, D. (1996). Noncontiguity and political architecture: the parliaments of small island states. Political Geography, 15(8), 697-713.

Anckar, D. (2002). Why are small island states democracies? The Round Table, 91(365), 375-390.

Anckar, D. (2006). Islandness or smallness? A comparative look at political institutions in small island states. Island Studies Journal, 1(1), 43-54.

Anckar, D. (2008). Microstate democracy revisited: Developments in time and space. The Open Political Science Journal, 1, 75-83.

Anckar, D., \& Anckar, C. (1995). Size, insularity and democracy. Scandinavian Political Studies, 18(4), 211-229.

Anckar, D., \& Anckar, C. (2000). Democracies without parties. Comparative Political Studies, 33(2), 225-247. 
Andrews, C. W. (2008). Legitimacy and context: Implications for public sector reform in developing countries. Public Administration and Development, 28(3), 171-180.

Argyriades, D. (1996). Neutrality and professionalism in the public service. In H. K. Asmerom \& E. P. Reis (Eds.), Democratization and bureaucratic neutrality (pp. 45-77). London: Macmillan Press.

Ashiya, M. (2009a, July 16). Civil service commission ge dhashugai masakkath kuran varah bodah dhathivey: Immigration [Working under the purview of the civil service commission is extremely difficult: Immigration]. Haveeru Daily. Retrieved from http://www.haveeru.com.mv

Ashiya, M. (2009b, July 14). Naifaru bodu miskkithuge imam vaki kohdhinumah edhi 400 ah vure gina meehun petitioneh hushahalhaifi [A petition has been submitted by over 400 citizens of the Naifaru Island urging the dismissal of imam of the main mosque]. Haveeru Daily. Retrieved from http://www.haveeru.com.mv

Ashiya, M. (2009c, February 23). Foakaidhoo mudhim qunoothu nukiyaathee rashu office bandhu koffai hunnathaa thin hafthaa vejje [Foakaidhoo island office has been closed for the past three weeks as citizens protest how the mudhim conduct the prayers]. Haveeru Daily. Retrieved from http://www.haveeru.com.mv

Asian Development Bank. (1997). Technical assistance to the Republic of Maldives for capacity building for the Maldives Audit Office (TAR: MLD 31107). Retrieved from http://www.adb.org/Documents/TARs/MLD/31107-MLDTAR.pdf

Asim, M. (2001). Performance appraisal in the Maldives public service: Challenges and issues. Public Administration and Development, 21(4), 289-296.

Asim, M. (2002). Public sector reform strategies: A note on recent practices in the Maldives. Labour and Management in Development Journal, 3(1), 1-14.

Attorney General's Office. (2012, May 31). Press release. Retrieved from http://agoffice.gov.mv/pdf/newsletters/04-2012.pdf

Australian Public Service Act 1999, Act No. 147 of 1999 as amended.

Baker, R. (1992). Scale and administrative performance: The governance of small states and microstates. In R. Baker (Ed.), Public administration in small and island states (pp. 5-25). West Hartford, CT: Kumarian Press.

Baldacchino, G. (2004). The coming of age of island studies. Tijdschrift voor Economische en Sociale Geografie, 95(3), 272-283. 
Baldacchino, G. (Ed.). (2007). A world of islands. An island studies reader. Charlottetown, Canada: The Institute of Island Studies, University of Prince Edward Island.

Banerjee, A. M. (1979). A preliminary report of an advisory mission on restructuring of the civil service and machinery of government in the Republic of Maldives. United Nations Economic and Social Commission for Asia and the Pacific.

Barberis, P. (1997). Conclusions: into the twenty-first century. In P. Barberis (Ed.), The civil service in an era of change (pp. 150-161). Aldershot, UK: Dartmouth.

Beetham, D. (Ed.). (1994). Defining and measuring democracy. London: SAGE Publications.

Beetham, D. (1996). Bureaucracy (2nd ed.). Minneapolis, MN: University of Minnesota Press.

Bell, H. C. P. (1921). Report on a visit to Male', Jan. 20 to Feb. 21, 1920. Sessional Papers, Ceylon XV. Colombo: Government Printer.

Bell, H. C. P. (2004). The Maldive islands. An account of the physical features, climate, history, inhabitants, productions and trade. New Delhi: Asian Education Services. (Original work published 1883).

Benedict, B. (Ed.). (1967). Problems of smaller territories. London: University of London/Athlone Press.

Bennett, A. (2004). Case study methods: Design, use, and comparative advantages. In D. F. Sprinz \& Y. Wolinsky-Nahmias (Eds.), Models, numbers and cases: Methods for studying international relations (pp. 19-55). Ann Arbor, MI: University of Michigan Press.

Berg, B. L. (2009). Qualitative research methods for the social sciences (7th ed.). Boston, MA: Allyn \& Bacon.

Berman, E. M., Bowman, J. S., West, J. P., \& Van Wart, M. (2006). Human resource management in public service. Paradoxes, processes, and problems (2nd ed.). Thousand Oaks, CA: SAGE Publications.

Birkland, T. A. (2005). An introduction to the policy process. Theories, concepts, and models of public policy making (2nd ed.). Armonk, NY: M.E. Sharpe.

Blau, P. M., \& Meyer, M. W. (1971). Bureaucracy in modern society (2nd ed.). New York: Random House.

Blondel, J., \& Müller-Rommel, F. (2007). Political elites. In R. J. Dalton \& H.-D. Klingemann (Eds.), The Oxford handbook of political behavior (pp. 818832). Oxford: Oxford University Press. 
Bonofer, J. A. (2010). The challenges of democracy in Maldives. International Journal of South Asian Studies, 25(2), 433-449.

Bossaert, D., \& Demmke, C. (2003). Civil services in the accession states. New trends and the impact of the integration process. Maastricht, the Netherlands: European Institute of Public Administration.

Bossaert, D., Demmke, C., Nomden, K., \& Polet, R. (2001). Civil services in the Europe of fifteen. Trends and new developments. Maastricht, the Netherlands: European Institute of Public Administration.

Bottomore, T. B. (1964). Elites and society. London: C. A. Watts \& Co. Ltd.

Bouchon, G. (1988). 'Regent of the sea'. Cannanore's response to Portuguese expansion, 1507-1528 (L. Shackley, Trans.). Oxford: Oxford University Press. (First published as Mamale de cananor, un adversaire de l'Inde Portugaise, 1507-1528, 1975, Paris: Librarie Droz)

Bratton, M., \& Mattes, R. (2001). Support for democracy in Africa. British Journal of Political Science, 31(3), 447-74.

Brown, D. R. (2008, October 19-22). Institutional development and reform in public services - Lessons from the experience of small Caribbean states. Paper presented at CAPAM biennial conference, Barbados.

Burnell, P. (2008). Democratization. In P. Burnell \& V. Randall (Eds.), Politics in the developing world (2nd ed., pp. 268-290). Oxford: Oxford University Press.

Burnell, P., \& Gerrits, A. (2010). Promoting party politics in emerging democracies. Democratization, 17(6), 1065-1084.

Burns, J. P. (1994). Asian civil service systems in comparative perspective. In J. P. Burns (Ed.), Asian civil service systems - Improving efficiency and productivity (pp. 3-13). Singapore: Times Academic Press.

Burns, J. P., \& Bowornwathana, B. (2001). Asian civil service systems in comparative perspective. In J. P. Burns \& B. Bowornwathana (Eds.), Civil service systems in Asia (pp. 1-23). Cheltenham, UK: Edward Elgar.

Burton, M., \& Higley, J. (2001). The study of political elite transformations. International Review of Sociology, 11(2), 181-199.

Butler, R. (1993). The evolution of the civil service - A progress report. Public Administration, 71(3), 395-406.

Caiden, G. E. (1996). The concept of neutrality. In H. K. Asmerom \& E. P. Reis (Eds.), Democratization and bureaucratic neutrality (pp. 20-44). London: Macmillan Press Ltd. 
Caldwell, J. C., Harrison, G. E., \& Quiggin, P. (1980). The demography of microstates. World Development, 8(12), 953-962.

Campbell, C., \& Peters, B. G. (1988). The politics/administration dichotomy: Death or merely change? Governance: An International Journal of Policy and Administration, 1(1), 79-99.

Campbell, D. T. (1988). Methodology and epistemology for social science. Selected papers. Chicago, IL: The University of Chicago Press.

Cardona, F. (2001). Building a civil service system. Public Management Forum, $\operatorname{VII}(1), 3-6$.

Cardona, F. (2002, September). Building a civil service system. SIGMA / OECD. Retrieved from http://www.oecd.org/site/sigma/publicationsdocuments/38736319.pdf

Carey, J. M. (2009). Legislative voting and accountability. Cambridge, UK: Cambridge University Press.

Carothers, T. (1999). Aiding democracy abroad. The learning curve. Washington, DC: Carnegie Endowment for International Peace.

Carothers, T. (2007). How democracies emerge. Journal of Democracy, 18(1), $12-$ 27.

Carr-Saunders, A. M., \& Wilson, P. A. (1964). The professions. London: Frank Cass \& Co (Original work published 1933).

Chaudhuri, K. N. (1985). Trade and civilisation in the Indian Ocean. An economic history from the rise of Islam to 1750. Cambridge, UK: Cambridge University Press.

Cheema, G. S. (2005). Building democratic institutions. Bloomfield, CT: Kumarian Press, Inc.

Cheetham, G., \& Chivers, G. (2005). Professions, competence and informal learning. Cheltenham, UK: Edward Elgar.

Chester, N. (1981). The English administrative system 1780-1870. Oxford, UK: Clarendon Press.

Choi, S., \& Whitford, A. B. (2011). A topography of civil service laws. International Public Management Journal, 14(1), 106 - 130.

Christensen, T., \& Lægreid, P. (1999). New public management: Design, resistance, or transformation? A study of how modern reforms are received in a civil service system. Public Productivity \& Management Review, 23(2), 169-193. 
Christensen, T., \& Lægreid, P. (2004). The fragmented state - the challenges of combining efficiency, institutional norms and democracy (Working paper 3). Stein Rokkan Centre for Social Studies.

Church, C. H. (1981). Revolution and red tape. The French ministerial bureaucracy 1770-1850. Oxford, UK: Clarendon Press.

Civil servants' salaries to be reduced by 12.5 percent on average. (2009, September 27). Haveeru Daily. Retrieved from http://www.haveeru.com.mv

Civil Service Act of the Maldives, (2007), No. 5/2007

Civil Service Act of the Maldives, Second Amendment. (2010), No. 5/2007

Civil Service Amendment Bill, (2008a).

Civil Service Amendment Bill, (2008b).

Civil Service Amendment Bill, (2008c).

Civil Service Amendment Bill, (2009).

Civil Service Bill. (2005).

Civil Service Commission. (2008, August 11). Public notice No. 188-A/2008/52. Male', Maldives: Civil Service Commission.

Civil Service Commission. (2009a). Civil service ge muwazzafunnah dhey allowance thakaai ehenihen inaayath thah [Allowances and benefits given to civil servants]. Male', Maldives: Civil Service Commission.

Civil Service Commission. (2009b, December 30). Circular No. 2009/17. Retrieved from http://www.csc.gov.mv/wp-content/uploads/Circular2009-17.pdf

Civil Service Commission. (2009c, 30 April). Press release. Male', Maldives: Civil Service Commission.

Civil Service Commission. (2010a). Maldives civil service regulation. Male', Maldives: Civil Service Commission.

Civil Service Commission. (2010b, November). Dhivehi civil service maqaam thakuge asaasee sharuthu - furathama islaah [Civil service job specifications - first amendment]. Male', Maldives: Civil Service Commission.

Civil Service Commission. (2011a). Annual report 2011. Retrieved from http://www.csc.gov.mv/

Civil Service Commission. (2011b, October 17). Press release. Male', Maldives: Civil Service Commission. 
Civil Service Commission responds to allegations. (2009, May 25). Haveeru Daily. Retrieved from http://www.haveeru.com.mv

Clarke, C., \& Payne, T. (Eds.). (1987). Politics, security and development in small states. London: Allen \& Unwin.

Coelho, V. H. (1997). Constitutional and political development in the Maldives. In V. Grover (Ed.), Encyclopaedia of Saarc nations - Maldives (pp. 45-64). New Delhi: Deep \& Deep Publications Pvt. Ltd.

Collins, P. (1993). Civil service reform and retraining in transitional economies: Strategic issues and options. Public Administration and Development, 13(4), 323-344.

Commission of National Inquiry. (2012). Report of the commission of national inquiry, Maldives. Retrieved from http://www.coni.org.mv

Commonwealth Secretariat. (1985). Vulnerability: Small states in the global society. London: Commonwealth Secretariat.

Commonwealth Secretariat. (1997). A future for small states: Overcoming vulnerability. Report by a Commonwealth Advisory Group. London: Commonwealth Secretariat.

Commonwealth Secretariat. (2006). The Commonwealth yearbook 2006. London: the Commonwealth Secretariat.

Constitution of the Republic of Maldives. (1968).

Constitution of the Republic of Maldives. (1998).

Constitution of the Republic of Maldives. (2008).

Cosgrove, D. (2007). Island passages. In G. Baldacchino (Ed.), Bridging islands. The impact of fixed links (pp. 15-27). Charlottetown, PE, Canada: The Acorn Press.

Creswell, J. W. (1998). Qualitative inquiry and research design. Choosing among five traditions. Thousand Oaks, CA: SAGE Publications.

Creswell, J. W. (2009). Research design. Qualitative, quantitative, and mixed methods approaches (3rd ed.). Los Angeles: SAGE Publications.

Crotty, M. (1998). The foundations of social research. Meaning and perspective on the research process. Crows Nest, Australia: Allen \& Unwin.

Crowards, T. (2002). Defining the category of 'small' states. Journal of International Development, 14(2), 143-179. 
Dahl, R. A. (1970). A critique of the ruling elite model. In E. O. Láumann, P. M. Siegel, \& R. W. Hodge (Eds.), The logic of social hierarchies (pp. 295-300). Chicago: Markham.

Dahl, R. (1971). Polyarchy: Participation and opposition. New Haven, CT: Yale University Press.

De Alwis, R. K. (2009). The history of and prospects for public sector reforms in Sri Lanka (Unpublished doctoral dissertation). Victoria University of Wellington, Wellington, New Zealand.

de Silva, C. R. (Ed.). (2009). Portuguese encounters with Sri Lanka and the Maldives. Translated texts from the ages of the discoveries. Farnham, UK: Ashgate.

Defence minister kamashaai finance minister kamah dhe beyfulhaku iskurahvaifi [A defence minister and a finance minister have been appointed]. (2004, September 1). Haveeru Daily. Retrieved from http://www.haveeru.com.mv

Demmke, C. (2004). European civil services between tradition and reform. Maastricht, the Netherlands: European Institute of Public Administration.

Demmke, C. (2005). Are civil servants different because they are civil servants? Who are the civil servants - and how? Maastricht, the Netherlands: European Institute of Public Administration.

Department of Information and Broadcasting. (1985). Maldives. A historical overview. Male', Maldives: Department of Information and Broadcasting.

Department of Information and Broadcasting. (1990). Maldives. Constitutional history. Male', Maldives: Department of Information and Broadcasting.

Department of National Planning. (2009). Statistical yearbook of Maldives 2009. Retrieved from http://planning.gov.mv/yearbook2009/

Department of National Planning. (2009/2010). Household income and expenditure survey. $\quad$ Retrieved from http://planning.gov.mv/hies/HIES2012/Indicator\%20sheet\%20(22.05.2012).p $\underline{\mathrm{df}}$

Department of National Planning. (2010). Statistical yearbook of Maldives 2010. Retrieved from http://planning.gov.mv/yearbook2010/index.html

Department of National Planning. (2011). Statistical yearbook of Maldives 2011. Retrieved from http://planning.gov.mv/YearBook2011/yearbook.html

Dhaulathuge media 20 dhuvahuge therey MBC aa havaalu kuran amurukoffi [Court orders the handover of the state media to MBC within 20 days]. (2011, May 12). Haveeru Daily. Retrieved from http://www.haveeru.com.mv 
Di Palma, G. (1990). To craft democracies. An essay on democratic transitions. Berkeley, CA: University of California Press.

Diamond, L. (Ed.). (1993). Political culture and democracy in developing countries. Boulder, CO: Lynne Rienner Publishers.

Diamond, L. (1999). Developing democracy. Towards consolidation. Baltimore, MD: The Johns Hopkins University Press.

Diamond, L., Linz, J. J., \& Lipset, S. M. (1995). Introduction: What makes for democracy? In L. Diamond, J. J. Linz, \& S. M. Lipset (Eds.), Politics in developing countries. Comparing experiences with democracy (2nd ed., pp. 1-66). Boulder, CO: Lynne Rienner Publishers.

Diamond, L., Lipset, S. M., \& Linz, J. (1987). Building and sustaining democratic government in developing countries: Some tentative findings. World Affairs, 150(1), 5-19.

Didi, M. A. (2005, November 14). Civil service bill. Maldives parliamentary debates.

Dimitrova, A. L. (2005). Europeanization and civil service reform in central and eastern Europe. In F. Schimmelfennig \& U. Sedelmeier (Eds.), The Europeanization of central and eastern Europe (pp. 71-90). Ithaca, NY: Cornell University Press.

Dimock, M. E., \& Dimock, G. O. (1969). Public administration (4th ed.). New York: Holt, Rinehart and Winston, Inc.

Dolowitz, D. P., \& Marsh, D. (1998). Policy transfer: a framework for comparative analysis. In M. Minogue, C. Polidano, \& D. Hulme (Eds.), Beyond the new public management. Changing ideas and practices in governance (pp. 3858). Cheltenham, UK: Edward Elgar.

Dolowitz, D. P., \& Marsh, D. (2000). Learning from abroad: The role of policy transfer in contemporary policy-making. Governance: An International Journal of Policy and Administration, 13(1), 5-24.

Dommen, E. (1980). Some distinguishing characteristics of island states. World Development, 8(12), 931-943.

Dommen, E. (1985). What is a microstate? In E. Dommen \& P. Hein (Eds.), States, microstates and islands (pp. 1-15). London: Croom Helm.

Dunn, R. E. (2005). The adventures of Ibn Battuta. A muslim traveler of the $14^{\text {th }}$ century. Berkeley, CA: University of California Press.

Dye, T. R. (1975). Understanding public policy (2nd ed.). Englewood Cliffs, NJ: Prentice Hall. 
Easa, A. (2009, November 18). Civil service amendment bill. Maldives parliamentary debates.

Eckaus, R. S. (1997). Is it beautiful to be small, or is it a burden? Journal of Eastern Caribbean Studies, 22(4), 1-30.

Eichbaum, C., \& Shaw, R. (Eds.). (2010). Partisan appointees and public servants. An international analysis of the role of the political adviser. Cheltenham, UK: Edward Elgar.

Eisenhardt, K. M. (1989). Building theories from case study research. The Academy of Management Review, 14(4), 532-550.

Ejifor, P. (2003). Welcome address by chairman conference local organising committee. In G. Onu (Ed.), Corruption and sustainable development: The third world perspectives (pp. 4-6). Onitsha, Anambra State, Nigeria: Bookpoint Ltd.

Elections Commission. (2008a). Presidential election 2008 report. Retrieved from http://www.elections.gov.mv/v2/media/documents/25.pdf

Elections Commission. (2008b). Annual report 2008. Retrieved from http://www.elections.gov.mv/v2/media/documents/124.pdf

Elections Commission. (2009a). Annual report 2009. Retrieved from http://www.elections.gov.mv/v2/media/documents/418.pdf

Elections Commission. (2009b). Parliament election 2009 report. Retrieved from http://www.elections.gov.mv/v2/media/documents/193..pdf

Elections Commission. (2010). Annual report 2010. Retrieved from http://www.elections.gov.mv/v2/media/documents/416..pdf

Emmanuel, P. (1976). Independence and viability: Elements of analysis. In V. A. Lewis (Ed.), Size, self-determination and international relations: The Caribbean (pp. 1-15). Mona, Jamaica: Institute of Social and Economic Research.

Employment Act of the Maldives, (2008), No. 2/2008

Esaiasson, P., \& Holmberg, S. (1996). Representation from above: Members of parliament and representative democracy in Sweden. Aldershot, UK: Dartmouth.

Euroconsult Mott MacDonald. (2008). Best Practices in Civil Service Reform. Reference and Resource Manual Public Sector Reform No. 1. Retrieved from http://www.extranet.ecbmb.nl/search.asp?q=best+practices+in+civil+service +reform 
Faber, M. (1992). Microstates, increasing integration and awkward imperatives of adjustment: The case of the Republic of the Maldives. In H. M. Hintjens \& M. D. D. Newitt (Eds.), The political economy of small tropical islands. The importance of being small (pp. 123-149). Exeter, UK: University of Exeter Press.

Faizal, M. (2005). Institutionalization of performance appraisal system-The case of the Maldivian public service (Unpublished master's thesis). University of Bergen, Norway.

Feeny, S., \& Rogers, M. (2008). Public sector efficiency, foreign aid and small island developing states. Journal of International Development, 20, 526-546.

Finlay, I. (1966). The civil service (Introduction to public administration series 6). Dublin: Institute of Public Administration.

Fish, M. S., \& Wittenberg, J. (2009). Failed democratization. In C. W. Haerpfer, P. Bernhagen, R. F. Inglehart, \& C. Welzel (Eds.), Democratization (pp. 24965). Oxford: Oxford University Press.

Flyvbjerg, B. (2011). Case study. In N. K. Denzin \& Y. S. Lincoln (Eds.), The SAGE handbook of qualitative research (4th ed., pp. 301-316). Thousand Oaks, CA: SAGE Publications.

Fournier, J. (1998). Administrative reform in the commission opinions concerning the accession of the central and eastern European countries to the European Union. In Preparing public administrations for the European administrative space (pp. 111-18). Paris: OECD, SIGMA Paper No. 23.

Fox, A. B. (1959). Power of small states: Diplomacy in World War II. Chicago: University of Chicago Press.

Freidson, E. (1994). Professionalism reborn. Theory, prophecy, and policy. Chicago, IL: The University of Chicago Press.

Frye, T. (2002). Presidents, parliaments, and democracy: Insights from the postcommunist world. In A. Reynolds (Ed.), The architecture of democracy: Constitutional design, conflict management, and democracy (pp. 81-103). Oxford: Oxford University Press.

Fulidhoo council ge civil service dhe muwazzafaku geygai madu kuran engummun council ge idhaaraa bandhu koffi [Fulidhoo Island council office closed in protest after two civil servants are suspended]. (2011, July 24). Haveeru Daily. Retrieved from http://www.haveeru.com.mv

Gayle, D. J. (1986). The small developing state. Brookfield, Vt.: Gower Publishing.

Gayoom, M. A. (2004, June, 9). Speech presented at Male', Maldives. 
Geddes, B. (1994). Politician's dilemma: Building state capacity in Latin America. Berkeley, CA: University of California Press.

George, A. L., \& Bennett, A. (2004). Case studies and theory development in the social sciences. Cambridge, MA: MIT Press.

Gerring, J. (2004). What is a case study and what is it good for? The American Political Science Review, 98(2), 341-54.

Gerth, H. H., \& Mills, C. W. (Eds.). (1948). From Max Weber: Essays in sociology. London: Routledge \& Kegan Paul.

Gladden, E. N. (1945). The civil service. Its problems and future. London: Staples Press.

Gladden, E. N. (1972a). A history of public administration. Volume I - From earliest times to the eleventh century. London: Frank Cass.

Gladden, E. N. (1972b). A history of public administration. Volume II - From the eleventh century to the present day. London: Frank Cass.

Glassner, M. I. (1990). Neptune's domain. A political geography of the sea. Boston, MA: Unwin Hyman.

Government of the Maldives v. Hanim, Court ruling no. 2008/HC-DM/12 (High Court of the Maldives. 2008), aff'd, Court ruling no. 2009/SC-A/09 (Supreme Court of the Maldives, 2011).

Gray, A. (1890). The voyage of François Pyrard of Laval to the East Indies, the Maldives, the Moluccas and Brazil. London: The Hakluyt Society.

Gray, D. E. (2009). Doing research in the real world (2nd ed.). London: SAGE Publications.

Grugel, J. (2002). Democratization - a critical introduction. Basingstoke, UK: Palgrave Macmillan.

Guttsman, W. L. (1960). Social stratification and political elite. The British Journal of Sociology, 11(2), 137-150.

Haleem, A. (2009, June 24). Meehun hoadhan youth ministreen iulaan kuree permanent secretary sarukaaruge siyaasathaa idhikolhu maqsadheh haasil kurumah: ministry [Permanent Secretary of the youth ministry advertised for the posts due an agenda against the government policy: Ministry]. Haveeru Daily. Retrieved from http://www.haveeru.com.mv

Hall, P. A., \& Taylor, R. C. R. (1996). Political science and the three new institutionalisms. Political Studies, 44(5), 936-957. 
Halligan, J. (2007). Anglo-American systems: Easy diffusion. In J. C. N. Raadschelders, T. A. J. Toonen, \& F. M. Van der Meer (Eds.), The civil service in the $21^{\text {st }}$ century. Comparative perspectives. (pp. 50-64). Basingstoke, UK: Palgrave Macmillian.

Hamdhoon, A. (2007, December 17). Sarukaaru muwazzafunge kanthah belehettun March in feshigen civil service commission in havaaluvanee [Personnel management function of government employees to be handed over to the civil service commission from March]. Haveeru Daily. Retrieved from http://www.haveeru.com.mv

Hamdhoon, A. (2008a, January 22). Sarukaaru muwazzafunge wazeefaage kanthakaa havaaluvumah sarukaaruge ehbaarulumeh nulibunu: Dr. Latheef [We did not receive the cooperation from the government in handing over the personnel management function of government employees: Dr. Latheef]. Haveeru Daily. Retrieved from http://www.haveeru.com.mv

Hamdhoon, A. (2008b, January 22). Muskulhi kuran jehey dholhu haaheh haa muwazzafun sarukaarugai ebathibi: Dr. Latheef [There are about one and a half thousand government employees who need to retire: Dr. Latheef]. Haveeru Daily. Retrieved from http://www.haveeru.com.mv

Hamdhoon, A. (2008c, March 18). Qaanoon islaahu kurumuge masakkath hi'gamun dhaairu, 65 aharu vefaivaa muwazzafunnah retirement notice fonuvan fashaifi [Retirement notice for government employees over 65 years are being sent while amendment to the act is ongoing]. Haveeru Daily. Retrieved from http://www.haveeru.com.mv

Hamdhoon, A. (2008d, October 19). DRP ah campaign kuri kamah bune civil service ge muwazzafaku geygai madhukuran angaifi [A civil servant suspended on allegation of campaigning for DRP]. Haveeru Daily. Retrieved from http://www.haveeru.com.mv

Hamdhoon, A. (2008e, May 1). Dhiha membarunge notice ge massala fenmathi vefai vanikoh civil service qanoon ah amalu kuran fashaifi [Civil service act has come into force while the ten members' case is unresolved]. Haveeru Daily. Retrieved from http://www.haveeru.com.mv

Hamdhoon, A. (2009a, January 11). Umurun 55 aharu vumakee vazeefaa in vaki kurumah dhey "licence" eh noon: Civil service commission [Voluntary retirement age of 55 is not a licence for redundancy: Civil service commission]. Haveeru Daily. Retrieved from http://www.haveeru.com.mv

Hamdhoon, A. (2009b, April 4). Civil service in sarukaarah ehbaarulun nudhey kamah bune commission ge membarun majileehuge dhaahilee committee ah haaziru kohfi [Civil service commissioners summoned to a parliamentary committee on allegation of not cooperating with the government]. Haveeru Daily. Retrieved from http://www.haveeru.com.mv 
Hamdhoon, A. (2009c, April 6). Muwazzafunnah wazeefaa dhee wazeefaa in vaki kureveynee qaanoonnaai qawaaid ge therein: Commission [Hiring and firing can be conducted within the legislation: Commission]. Haveeru Daily. Retrieved from http://www.haveeru.com.mv

Hamdhoon, A. (2009d, April 30). Vaki candidate akah vote dhinumah baaru alhai civil service ge muwazzafunnah biru dhakkaa massala thah shareeathah husha halhan nimmaifi [Cases where civil servants are threatened to vote specific candidates shall be submitted to the court]. Haveeru Daily. Retrieved from http://www.haveeru.com.mv

Hamdhoon, A. (2009e, May 23). Civil service gai vaki dhaulathehge sifa jehifaivaa kamah vidhaalhuve sarukaarun varah bodah faadu kiyaifi [Government strongly criticises civil service accusing them of acting as a distinct state]. Haveeru Daily. Retrieved from http://www.haveeru.com.mv

Hamdhoon, A. (2009f, October 21). Zinmaadhaaru veringe massalaigai civil service commissionun home ministry ge mahchah dhauvaa hushahalhaifi [Civil service commission submit a case against the ministry of home affairs regarding the case of responsible officers]. Haveeru Daily. Retrieved from http://www.haveeru.com.mv

Hamdhoon, A. (2009g, May 2). Th.Thimarafuhtaai Quraidhoo katheebu adhi si'hee dhaairaage baeh meehun vaki muhdhathakah ehen rah rashah badhalu kuran hushahalhaifi [A request has been made to temporarily transfer a number of civil servants in the island of Th.Thimarafushi and Th.Quraidhoo]. Haveeru Daily. Retrieved from http://www.haveeru.com.mv

Hamdhoon, A. (2009h, February 9). Civil service commission ge noos bayaan vazeefaain vaki kuraane kamah bune civil service muwazzafunnah biru dhahkaa kamuge shakuvaa thakeh vane hushahalhaifai [Press release by civil service commission - A number of complains submitted regarding threat of dismissal]. Haveeru Daily. Retrieved from http://www.haveeru.com.mv

Hamdhoon, A. (2009i, December 15). GDh.Thauleemee marukazuge deputy principle geygai madu kuran engi enngun baathil kohdhinumah court ah hushahalhaifi [A case submitted to the court to invalidate the suspension of the deputy principle of the GDh atoll education centre]. Haveeru Daily. Retrieved from http://www.haveeru.com.mv

Hamdhoon, A. (2009j, January 7). Home ministry ge dhaairaa in haaheh haa meehun wazeefaain vaki kurumah sarukaarun edhefi [Government request to make about a thousand employees of the ministry of home affairs redundant]. Haveeru Daily. Retrieved from http://www.haveeru.com.mv

Hamdhoon, A. (2010a, February 9). Zinmaadhaaru veringe masooliyyathu neh kamah sarukaarun bunaa bunun courtun baathil koffi [Court rules against the government on the case of responsible officers]. Haveeru Daily. Retrieved from http://www.haveeru.com.mv 
Hamdhoon, A. (2010b, February 24). Civil service commissionun sarukaaru vahtaalan ulhey kamah bune finansun fuluhunnah massala hushahalhaifi [Ministry of finance submit a case against the civil service commission to the police on the allegation of attempting to topple the government]. Haveeru Daily. Retrieved from http://www.haveeru.com.mv

Hamdhoon, A. (2010c, January 19). Musaara sheet hadhaa muwazaffunah dhefaraathuge inzaaru [Finance officers preparing salary sheets receive threats from both sides]. Haveeru Daily. Retrieved from http://www.haveeru.com.mv

Hamdhoon, A. (2010d, January 20). Kuda kuri musaara balaigen noon gothakah musaara sheet thayyaaru koffi nama qaanoonee fiyavalhu elheyne: Finance [Legal action to be taken if salary sheets are not prepared based on the reduced salary: Finance]. Haveeru Daily. Retrieved from http://www.haveeru.com.mv

Hamdhoon, A. (2010e, January 21). Eaadha kuri musaara aa ehgothah musaara sheet hadhan engummun defence ge permanent secretary ge ah fonuvaalaifi [Permanent secretary at the ministry of defence suspended after she instructed to make the salary sheets based on the reinstated salary]. Haveeru Daily. Retrieved from http://www.haveeru.com.mv

Hamdhoon, A. (2010f, February 4). Musaaraige massala ha'lluvandhen ves massakathuge vaguthu kuda kurumah gina muwazzafun thakeh sarukaaugai aadheys kuranee [Several employees plea to reduce the working hours until the salary disputes are resolved]. Haveeru Daily. Retrieved from http://www.haveeru.com.mv

Hamdhoon, A. (2010g, September 29). Fannee, professional meehun civil service dhookoh dhiumuge massala varah bodu vejje: Fahumee [Technical and professional civil servants leaving the service have become a serious issue: Fahmy]. Haveeru Daily. Retrieved from http://www.haveeru.com.mv

Hamdhoon, A. (2011, March 31). Male' city council ge onigandu adhives commissionah hushahalhaafa eh neh: CSC [Organisational structure of the Male' city council has not been submitted to the commission: CSC]. Haveeru Daily. Retrieved from http://www.haveeru.com.mv

Hanim v. Government of the Maldives (2008), High Court of the Maldives. (Court ruling no. 2008/HC-DM/12).

Harden, S. (Ed.). (1985). Small is dangerous: Micro states in a macro world. New York: St. Martin's Press.

Hart, J. (1972). The genesis of the Northcote-Trevelyan report. In G. Sutherland (Ed.), Studies in the growth of nineteenth-century government (pp. 63-81). London: Routledge \& Kegan Paul. 
Hattenhauer, H. (1979). Geschichte des beamtentums. In W. Wiese (Ed.), Handbuch des öffentlichen dienstes. Cologne: $\mathrm{C}$ Heymann Verlag.

Hecker, H. (1986). The Maldives. In A. P. Blaustein \& G. H. Flanz (Eds.), Constitutions of the countries of the world. New York: Oceana Publications, Inc.

Held, D., McGrew, A., Goldblatt, D., \& Perraton, J. (1999). Globalization. Global Governance, 5(4), 483-96.

Henderson, J. (2003). The future of democracy in Melanesia: What role for outside powers? Asia Pacific Viewpoint, 44(3), 225-241.

Henderson, K. M., \& Dwivedi, O. P. (Eds.). (1999). Bureaucracy and the alternatives in world perspective. Basingstoke, UK: Macmillan.

Hennessy, P. (1989). Whitehall. London: Secker and Warberg.

Henry, N. (2010). Public administration and public affairs (11th ed.). New York: Longman.

Heyen, E. V. (Ed.). (1989). Formation und Transformation des Verwaltungswissens in Frankreich und Deutschland (18./19. Jh.). Jahrbuch für europäische Verwaltungsgeschichte 1. Baden-Baden: Nomos Verlagsgesellschaft.

Heyerdahl, T. (1986). The Maldive mystery. London: George Allen \& Unwin.

Higley, J., \& Burton, M. (2006). Elite foundations of liberal democracy. Lanham, MD: Rowan and Littlefield.

Hithadhoo school ge principal badhalu kohdhinumah edhi petitioneh hushahalhaifi [A petition submitted requesting the transfer of the principal at Hithadhoo school]. (2012, January 13). Haveeru Daily. Retrieved from http://www.haveeru.com.mv

Hockly, T. W. (1935). The two thousand isles. A short account of the people, history and customs of the Maldive archipelago. London: H. F. \& G. Witherby.

Hofstede, G. (1991). Cultures and organizations - Software of the mind. London: McGraw-Hill Book Company.

Hojnacki, W. P. (1996). Politicization as a civil service dilemma. In H. A. G. M. Bekke, J. L. Perry, \& T. A. J. Toonen (Eds.), Civil service systems in comparative perspective (pp. 137-164). Bloomington, IN: Indiana University Press.

Hood, C. (1995). The "New Public Management" in the 1980s: Variations on a theme. Accounting, Organizations and Society, 20(2-3), 93-109. 
Hood, C., \& Lodge, M. (2006). The politics of public service bargains. Reward, competency, loyalty - and blame. Oxford: Oxford University Press.

Hope, K. R. (1983). The administration of development in emergent nations. The problems in the Caribbean. Public Administration and Development, 3(1), 49-59.

Howlett, M., Ramesh, M., \& Perl, A. (2009). Studying public policy. Policy cycles \& policy subsystems (3rd ed.). Oxford: Oxford University Press.

Hughes, O. E. (2012). Public management and administration. An introduction (4th ed.). Basingstoke, UK: Palgrave Macmillan.

Huntington, S. P. (1984). Will more countries become democratic? Political Science Quarterly, 99(2), 193-218.

Huntington, S. P. (1991/1992). How countries democratize. Political Science Quarterly, 106(4), 579-616.

Hussain, M. (2006, December 19). Civil service bill. Maldives parliamentary debates.

Hyneman, C. S. (1950). Bureaucracy in a democracy. New York: Harper \& Brothers Publishers.

Ibrahim, A. (1998). Religions' potential contribution to harmonious regional relations in South and Southeast Asia: A Maldivian perspective. In N. N. Vohra \& J. N. Dixit (Eds.), Religion, politics and society in South and Southeast Asia (pp. 20-24). New Delhi: Konark Publishers.

Inglehart, R. (2003). How solid is mass support for democracy - and how do we measure it? PS Political Science and Politics, 36, 51-57.

Inglehart, R., \& Baker, W. E. (2000). Modernization, cultural change, and the persistence of traditional values. American Sociological Review, 65(1), 19-51.

Ingraham, P. W. (1987). Building bridges or burning them? The president, the appointees, and the bureaucracy. Public Administration Review, 47(5), 425435.

Ingraham, P. W. (1995). The foundation of merit - Public service in American democracy. Baltimore, MD: The Johns Hopkins University Press.

Ingraham, P. W., \& Rosenbloom, D. H. (1990). Political foundations of the American federal service: Rebuilding a crumbling base. Public Administration Review, 50(2), 210-219.

Ingraham, P. W., Thompson, J. R., \& Eisenberg, E. F. (1995). Political management strategies and political/career relationships: Where are we now in the federal government? Public Administration Review, 55(3), 263-272. 
International Federation of Journalists (2011). Free speech in peril. Press freedom in South Asia 2010-11. Retrieved from http://asiapacific.ifj.org/assets/docs/043/219/7bb382b-82afadb.pdf

International Monetary Fund. (2009). Maldives: Public financial management Performance report (IMF Country Report No. 10/137). Washington, DC: International Monetary Fund.

Jackson, R. (1987, September). Civil science: A rule-based paradigm for comparative government. Paper presented at the annual conference of the American political science association, Chicago.

Jacobs, B. L. (1975) Administrative problems of small countries. In P. Selwyn (Ed.), Development policy in small countries (pp. 134-143). London: Croom Helm London.

Jacoby, H. (1973). The Bureaucratization of the world. Berkeley, CA: University of California Press.

Jameel, A. (2009, April 23). Siyaasee baeh beyfulhun civil service ge muwazzafunnah inzaaru dheythee civil service commissionun ekan kuhveri koffi [Civil service commission condemns the threats made by some politicians towards civil servants]. Haveeru Daily. Retrieved from http://www.haveeru.com.mv

Jenei, G., \& Zupko, G. (2001). Public sector performance in a new democratic state: The Hungarian case. International Review of Administrative Sciences, 67(1), 77-98.

Jones, E. (1976). Bureaucracy as a problem-solving mechanism in small states: A review in terms of the current literature. In V. A. Lewis (Ed.), Size, selfdetermination and international relations: The Caribbean (pp. 73-97). Mona, Jamaica: Institute of Social and Economic Research.

Jordan, G. (1994). The British administrative system. Principles versus practice. London: Routledge.

Kapstein, E. B., \& Converse, N. (2008). The fate of young democracies. Cambridge: Cambridge University Press.

Kernaghan, K. (1976). Politics, policy and public servants: Political neutrality revisited. Canadian Public Administration, 19(3), 432-456.

Kernaghan, K. (1986). Political rights and political neutrality: Finding the balance point. Canadian Public Administration, 29(4), 639-652.

Kernaghan, K., \& Langford, J. W. (1990). The responsible public servant. Halifax: The Institute for Research on Public Policy. 
Khan, J. (1982). Public management: The eastern Caribbean experience. Holland: Royal Institute of Linguistics and Anthropology.

Kingdom, J. E. (Ed.). (1990). The civil service in liberal democracies - An introductory survey. London: Routledge.

Knack, S. (2004). Does foreign aid promote democracy? International Studies Quarterly, 48(1), 251-266.

Kotze, H., \& Du Toit, P. (1995). The state, civil society, and democratic transition in South Africa: A survey of elite attitudes. The Journal of Conflict Resolution, 39(1), 27-48.

Laking, R. (2007). International civil service reform: Lessons for the Punjab? Asian Development Bank.

Laking, R. (2008). Accountability institutions and oversight bodies in East Asia and the Pacific. World Bank.

Lam, T. C., \& Chan, H. S. (1995). Designing China's civil service system: General principles and realities. International Journal of Public Administration, 18(8), 1297-1332.

Lapan, S. D., Quartaroli, M. T., \& Riemer, F. J. (2012). Introduction to qualitative research. In S. D. Lapan, M. T. Quartaroli, \& F. J. Riemer (Eds.), Qualitative research. An introduction to methods and designs (pp. 3-18). San Francisco, CA, Jossey-Bass.

Larson, M. S. (1990). In the matter of experts and professionals, or how impossible it is to leave nothing unsaid. In R. Torstendahl \& M. Burrage (Eds.), The formation of professions. Knowledge, state and strategy (pp. 24-50). London: SAGE Publications.

Lasswell, H. (1961). Agenda for the study of political elites. In D. Marvick (Ed.), Political decision-makers (pp. 264-287). Glencoe, IL: The Free Press of Glencoe.

Latheef, M. (1993). Administrative accountability in the civil service in the Maldives (unpublished report). Study conducted as part of the regional research on "Administrative accountability in the civil service in south Asia", sponsored by the Asian and Pacific Development Centre.

Letki, N. (2009). Social capital and civil society. In C.W. Haerpfer, P. Bernhagen, R. F. Inglehart, \& C. Welzel (Eds.), Democratization (pp. 158-169). Oxford: Oxford University Press.

Lhaimagu chief suspended from work, his salary also withheld. (2012, January 16). Sun. Retrieved from http://sun.mv 
Light, P. C. (1995). Thickening government. Federal hierarchy and the diffusion of accountability. Washington, DC: The Brookings Institution.

Lijphart, A. (1977). Democracy in plural societies. A comparative exploration. New Haven, CT: Yale University Press.

Lilleker, D. G. (2003). Interviewing the political elite: Navigating a potential minefield. Politics, 23(3), 207-214.

Lindblom, C. E. (1977). Politics and markets. The world's political economic systems. New York: Basic Books.

Linz, J. J. (1978). Elements of breakdown. In J. J. Linz \& A. Stepan (Eds.), The breakdown of democratic regimes. Crisis, breakdown, \& reequilibration (pp. 14-49). Baltimore, MD: The Johns Hopkins University Press.

Linz, J. J. (1990). Transitions to democracy. The Washington Quarterly, 13(3), 143 164.

Linz, J. J., \& Stepan, A. (1996). Problems of democratic transition and consolidation - Southern Europe, South America, and post-communist Europe. Baltimore, MD: The Johns Hopkins University Press.

Lipset, S. M. (1959). Some social requisites of democracy: Economic development and political legitimacy. The American Political Science Review, 53(1), 69105.

Loveless, M. (2008). Media dependency: Mass media as sources of information in the democratizing countries of central and eastern Europe. Democratization, 15(1), 162-183.

Lægreid, P. (2002). Transforming top civil servant systems. In T. Christensen \& P. Lægreid (Eds.), New public management. The transformation of ideas and practice (pp. 145-171). Aldershot, UK: Ashgate.

Lægreid, P., \& Wise, L. R. (2007). Reforming human resource management in civil service systems: Recruitment, mobility, and representativeness. In J. C. N. Raadschelders, T. A. J. Toonen, \& F. M. Van der Meer (Eds.), The civil service in the 21st century. Comparative perspectives (pp. 169-182). Basingstoke, UK: Palgrave Macmillan.

Mabry, L. (2008). Case study in social research. In P. Alasuutari, L. Bickman, \& J. Brannen (Eds.), The SAGE handbook of social research methods (pp. 214227). London: SAGE Publications.

Maldives Journalist Association. (2011, May 6). Police attacking media. Retrieved from http://www.maldivesjournalistassociation.org/index.php/news/164police-attacking-media 
Maldives Monetary Authority. (2001). Annual report and financial accounts 1999. Male', Maldives: Maldives Monetary Authority.

Maldives MPs back democracy move. (2005, June 2). BBC News. Retrieved from http://news.bbc.co.uk

Maldives parliamentary debates. (2005, October 27). Civil service amendment bill.

Maloney, C. (1976). The Maldives: New stresses in an old nation. Asian Survey, 16(7), 654-671.

Maloney, C. (1980). People of the Maldive islands. Bombay: Orient Longman.

Maniku, A. N. H. (2009, November 18). Civil service amendment bill. Maldives parliamentary debates.

March, J. G., \& Olsen, J. P. (1984). The new institutionalism: Organization factors in political life. The American Political Science Review, 78(3), 734-749.

Maumoon, Y. (2002). A general overview of the dhivehi language. Male', Maldives: Novelty Printers and Publishers. Retrieved from http://www.qaumiyyath.gov.mv/docs/whitepapers/language/GENERAL\%20 OVERVIEW\%200F\%20DHIVEHI\%20LANGUAGE.pdf

Maxwell, J. A. (2009). Designing a qualitative study. In L. Bickman \& D. J. Rog (Eds.), The SAGE handbook of applied social research methods (2nd ed., pp. 214-253). Los Angeles: SAGE Publications.

May, P. J. (2003). Policy design and implementation. In B. G. Peters \& J. Pierre (Eds.), Handbook of public administration (pp. 223-233). London: SAGE Publications.

McCubbins, M., Noll, R., \& Weingast, B. (1987). Administrative procedures as instruments of political control. Journal of Law, Economics, and Organization, 3(2): 243-277.

Meier. K. J. (1987). Politics and the bureaucracy. Policymaking in the fourth branch of government. Monterey, CA: Brooks / Cole Publishing Company.

Meisel, J. H. (1962). The myth of the ruling class: Gaetano Mosca and the elite. Ann Arbor, MI: University of Michigan Press.

Mendel, T. (2009). Assessment of media development in the Maldives. Based on UNESCO's media development indicators. Retrieved from http://unesdoc.unesco.org/images/0018/001871/187165e.pdf

Merriam, S. B. (2009). Qualitative research. A guide to design and implementation. San Francisco, CA, Jossey-Bass. 
Meyer, T. (2002). Media democracy: How the media colonize politics. Cambridge: Polity.

Meyer-Sahling, J.-H. (2004). Civil service reform in post-communist Europe: The bumpy road to depoliticisation. West European Politics, 27(1), 71-103.

Meyer-Sahling, J.-H. (2008). The changing colours of the post-communist state: The politicisation of the senior civil service in Hungary. European Journal of Political Research, 47(1), 1-33.

Meyer-Sahling, J.-H. (2009). Sustainability of civil service reforms in central and eastern Europe five years after EU accession, SIGMA Papers, No. 44, OECD Publishing.

Miller, G. J., \& Moe, T. M. (1983). Bureaucrats, legislators, and the size of government. The American Political Science Review, 77(2), 297-322.

Mills, C. W. (1956). The power elite. New York: Oxford University Press.

Ministry of Finance and Treasury. (2009, October 29). Maldives Private Sector Participation Policy. Retrieved from http://www.majlis.gov.mv/di/committees/budget_committee_report

Ministry of Finance and Treasury. (2011, December 11). Letter No. 13E2/57/2011/84. Retrieved from http://www.majlis.gov.mv/di/committees/budget_committee_report

Ministry of Home Affairs. (2010). Club, jamiyyaa thakuge qaumee forum 2010 ge report [Report on the national forum 2010 of civil society organisations]. Retrieved from http://homeaffairs.gov.mv/files/REPORT.pdf

Ministry of Information and Arts. (2007). Maldives media. Retrieved from http://www.maldivesinfo.gov.mv/home/upload/downloads/mbook.pdf

Ministry of Planning and National Development. (2004). Statistical yearbook of Maldives 2004. Retrieved from http://www.planning.gov.mv/publications/yrb2004/yrb04/all.htm

Ministry of Planning and National Development. (2005a). 25 years of statistics. Retrieved from http://www.planning.gov.mv/publications/25yearsstats/default.htm

Ministry of Planning and National Development. (2005b). Tsunami impact assessment 2005. Retrieved from http://www.planning.gov.mv/publications/TIA/TIA_2005_Main_Report.pdf

Ministry of Planning and National Development. (2005c). Statistical yearbook of Maldives 2005. Retrieved from http://www.planning.gov.mv/publications/yearbook2005/yrb05/all.htm 
Ministry of Planning and National Development. (2006). Statistical yearbook of Maldives 2006. Retrieved from http://www.planning.gov.mv/publications/yrb2006/yrb05/all.htm

Ministry of Planning and National Development. (2007a). Seventh national development plan 2006-2010: Creating new opportunities. Retrieved from http://www.planning.gov.mv/en/images/stories/ndp/seventh ndp.pdf

Ministry of Planning and National Development. (2007b). Statistical yearbook of Maldives 2007. Retrieved from http://www.planning.gov.mv/en/images/stories/publications/yearbooks/2007/ yearbook.html

Ministry of Planning and National Development. (2008a). Census 2006. Analytical report. Retrieved from http://planning.gov.mv/en/images/stories/publications/analysiscd/index.html\#

Ministry of Planning and National Development. (2008b). Statistical yearbook of Maldives 2008. Retrieved from http://planning.gov.mv/yearbook2008/yearbook.html

Mishra, R. K. (2001). The national civil service system of India: A critical view. In J. P. Burns \& B. Bowornwathana (Eds.), Civil service systems in Asia (pp. 11751). Cheltenham, UK: Edward Elgar.

Misra, A. (2004). Theorising 'small' and 'micro' state behaviour using the Maldives, Bhutan and Nepal. Contemporary South Asia, 13(2), 133-148.

Mohamed, H. (2009, March 2). Naruhun muzaaharaa kuraa kamah vane nama e maqaam thakah ehen bayaku hoadhumah thaa member Afeef govaalahvaifi [MP Afeef calls to hire new staff if the current nurses go on strike]. Haveeru Daily. Retrieved from http://www.haveeru.com.mv

Mohamed, I. (2005). Globalization, governance and development: The case of the Maldives (Unpublished doctoral dissertation). Dalhousie University, Halifax, Canada.

Mohamed, N. (2002). Pre-Islamic Maldives. Man and Environment Journal of the Indian Society for Prehistoric and Quaternary Studies, 27(1), 109-115.

Mohamed, N. (2005). Maldivian seafaring in the pre-Portuguese period. Retrieved from http://www.qaumiyyath.gov.mv/docs/whitepapers/history/seafaring.pdf

Mohamed, N. (2008). Essays on early Maldives. Male', Maldives: National Centre for Linguistic and Historical Research.

Mohamed, N. (n.d.). Rebellion of the southern atolls. Retrieved from http://www.qaumiyyath.gov.mv/docs/whitepapers/history/southern\%20rebelli on.pdf 
Moon, M.-J., \& Ingraham, P. (1998). Shaping administrative reform and governance: An examination of the political nexus triads in three Asian countries. Governance: An International Journal of Policy and Administration, 11(1), 77-100.

Moosa, H. F. (2008a, December 18). Civil service ge baeh muwazzafun sarukaarah ehbaarulumeh nudhey: membarun [Some civil servants do not cooperate with the government: MPs]. Haveeru Daily. Retrieved from http://www.haveeru.com.mv

Moosa, H. F. (2008b, April 2). Baeh muwazzafunnaai muahsasaathah civil service in vaki kurumah commission thakeh ufehdhumah sarukaarun nimmaifi [Government decides to establish a number of commissions to remove a number of employees and organisations out of the purview of civil service]. Haveeru Daily. Retrieved from http://www.haveeru.com.mv

Morgan, E. P., \& Perry, J. L. (1988). Re-orienting the comparative study of civil service systems. Review of Public Personnel Administration, 8(3), 84-95.

Morlino, L. (2009). Political parties. In C. W. Haerpfer, P. Bernhagen, R. F. Inglehart, \& C. Welzel (Eds.), Democratization (pp. 201-218). Oxford: Oxford University Press.

Morris, T., \& Wood, S. (1991). Testing the survey method. Continuity and change in British industrial relations. Work, Employment and Society, 5(2), 259-82.

Mosca, G. (1939). The ruling class. New York: McGraw-Hill.

Mosher, F. C. (1982). Democracy and the public service. New York: Oxford University Press.

Mukherjee, R., \& Manning, N. (2000). Rewards \& Incentives. Retrieved from http://go.worldbank.org/5WX73RM0D0

Murray, D. J. (1981). Microstates: Public administration for the small and beautiful. Public Administration and Development, 1(3), 245-256.

Naafiz, A., \& Ahmed, F. (March 22, 2011). Male' mayor slams 'bureaucratic' CSC for lack of cooperation. Haveeru Daily. Retrieved from http://www.haveeru.com.mv

Nasheed, M. (2003). Maldives. A historical overview of traditional dhivehi polity 1800-1900. Male', Maldives: Orient Academic Centre.

Nasheed, M. (2008a, March 18). Civil service amendment bill. Maldives parliamentary debates.

Nasheed, M. (2008b, April 1). Civil service amendment bill. Maldives parliamentary debates. 
Nasheed, M. (2008c, March 17). Civil service amendment bill. Maldives parliamentary debates.

National Language (priority) Act of the Maldives, (2011), No. 9/2011

Nazim, A. (2005a, October 27). Civil service bill. Maldives parliamentary debates.

Nazim, A. (2005b, November 14). Civil service bill. Maldives parliamentary debates.

Nazim, A. (2006, December 19). Civil service bill. Maldives parliamentary debates.

Nazim, A. (2008, March 17). Civil service amendment bill. Maldives parliamentary debates.

Nelson, W. E. (1982). The roots of American bureaucracy 1830-1900. Cambridge, MA: Harvard University Press.

Neshkova, M. I., \& Kostadinova, T. (2012). The effectiveness of administrative reform in new democracies. Public Administration Review, 72(3), 324-333.

Newitt, M. (1992). Introduction. In H. M. Hintjens \& M. D. D. Newitt (Eds.), The political economy of small tropical islands. The importance of being small (pp. 1-17). Exeter, UK: University of Exeter Press.

Nigro, L. G. (2006). Public personnel management and the challenges of democratic governance. In N. M. Riccucci (Ed.), Public personnel management. Current concerns, future challenges (pp. 1-17). New York: Longman.

Norcross, A. W. (1984). Reconstituting the Maldivian civil service: Terminal report (unpublished report). Male', Maldives.

Nunberg, B. (1992). Managing the civil service. What LDCs can learn from developed country reforms. World Bank Working Paper No. 945, Washington, DC: World Bank.

Nunberg, B. (1995). Managing the civil service. Reform lessons from advanced industrialized countries. World Bank Discussion Papers No. 204, Washington, DC: World Bank.

O’Donnell, G. (1996). Illusions about consolidation. Journal of Democracy, 7(2), $15-33$.

O'Donnell, G. (1998). Horizontal accountability in new democracies. Journal of Democracy, 9(3), 112-126.

O'Donnell, G., \& Schmitter, P. C. (1986). Transitions from authoritarian rule. Tentative conclusions about uncertain democracies. Baltimore, MD: The Johns Hopkins University Press. 
O'Donnell, G., Schmitter, P. C., \& Whitehead, L. (1986). Transitions from authoritarian rule. Latin America. Baltimore, MD: Johns Hopkins University Press.

Official Kanthah [Issues] Chapter 1, (1968), No. 1/68J

Official Kanthah [Issues] Chapter 2, (1968), No. 2/68J

Olsen, J. P. (2005). Maybe it is time to rediscover bureaucracy. Journal of Public Administration Research and Theory, 16(1), 1-24.

Olsen, J. P. (2009). Change and continuity: an institutional approach to institutions of democratic government. European Political Science Review, 1(1), 3-32.

Olsen, J. P., \& Peters, B. G. (1996). Learning from experience? In J. P. Olsen \& B. G. Peters (Eds.), Lessons from experience. Experiential learning in administrative reforms in eight democracies (pp. 1-35). Oslo: Scandinavian University Press.

Olson, D. M., \& Mezey, M. L. (1991). Parliaments and public policy. In D. M. Olson \& M. L. Mezey (Eds.), Legislatures in the policy process. The dilemmas of economic policy (pp. 1-24). Cambridge: Cambridge University Press.

Organisation for Economic Co-operation and Development. (1996). Civil service legislation contents checklist. SIGMA Papers No. 5. Paris: OECD/SIGMA.

Organisation for Economic Co-operation and Development. (1997a). Promoting performance and professionalism in the public service. SIGMA Papers No. 21. Paris: OECD/SIGMA.

Organisation for Economic Co-operation and Development. (1997b). Civil service legislation: Checklist on secondary legislation (and other regulatory instruments). SIGMA Papers No. 14. Paris: OECD/SIGMA.

Organisation for Economic Co-operation and Development. (1999). European principles for public administration. SIGMA Papers No. 27. Paris: OECD/SIGMA.

Organisation for Economic Co-operation and Development. (2004). Modernising government: The synthesis. Report No. GOV/PGC(2004)17. Paris: OECD.

Organisation for Economic Co-operation and Development. (2007). Political advisors and civil servants in European countries. SIGMA Papers No. 38. OECD Publishing.

Orum, A. M., Feagin, J. R., \& Sjoberg, G. (1991). Introduction. The nature of the case study. In J. R. Feagin, A. M. Orum, \& G. Sjoberg (Eds.), A case for the case study (pp. 1-26). Chapel Hill, NC: The University of North Carolina Press. 
Ostrom, E. (1985). The rudiments of a revised theory of the origins, survival, and performance of institutions for collective action. Bloomington, IN: Workshop in Political Theory and Policy Analysis.

Ott, D. (2000). Small is democratic. An examination of state size and democratic development. New York: Garland Publishing, Inc.

Page, E. C. (1992). Bureaucratic authority and political power: A comparative analysis (2nd ed.). New York: Harvester.

Page, E. C., \& Wright, V. (Eds.). (1999). Bureaucratic elites in western European states. A comparative analysis of top officials. Oxford: Oxford University Press.

Pagnucco, R. (1995). The comparative study of social movements and democratization: Political interaction and political process approaches. In M. Dobkowski, I. Wallimann, \& C. Stojanov (Eds.), Research in social movements, conflict and change. Volume 18 (pp. 145-183). London: JAI Press.

Pallot, J. (1998). The New Zealand revolution. In O. Olson, J. Guthrie, \& C. Humphrey (Eds.), Global warning! Debating international development in new public financial management (pp. 156-184). Oslo: Cappelen Akademisk Forlag.

Pareto, V. (1935). The mind and society: a treatise on general sociology. New York: Dover.

Parmanand (1997). Wind of change: Fresh stirrings in the Maldives. In V. Grover (Ed.). Encyclopaedia of Saarc nations - Maldives (pp. 116-120). New Delhi: Deep \& Deep Publications Pvt. Ltd.

Parris, H. (1969). Constitutional bureaucracy. The development of British central administration since the eighteenth century. London: George Allen \& Unwin.

Parsons, T. (Ed.). (1947). Max Weber. The theory of social and economic organization. (Translated by A. M. Henderson and Talcott Parsons) New York: The Free Press.

Part, A. (1990). The making of a mandarin. London: Andre Deutsch.

Patton, M. Q. (1990). Qualitative evaluation and research methods (2nd ed.). Newbury Park, CA: SAGE Publications.

Payne, R. J., \& Nassar, J. R. (2010). Politics and culture in the developing worldThe impact of globalization (4th ed.). Boston: Longman.

Pei, M. (2002). Implementing the institutions of democracy. International Journal on World Peace, 19(4), 3-31. 
Pelliot, P. (1904). Deus Itineraires de Chine en Inde a la fin du Villie Siecle. Ecole Francaise d'Extreme Orient. Bulletin No.4. (pp. 359-362). Chinese T'ang Dynasty. Document written in 785-805 A.D. (Documented by Pelliot): Paris.

Pension Act of the Maldives, (2009), No. 8/2009

Peters, B. G. (2003). Administrative traditions and the Anglo-American democracies. In J. Halligan (Ed.), Civil service systems in Anglo-American countries (pp. 10-26). Cheltenham, UK: Edward Elgar.

Peters, B. G. (2010). The politics of bureaucracy: An introduction to comparative public administration (6th ed.). London: Routledge.

Peters, B. G., \& Pierre, J. (Eds.). (2004). Politicization of the civil service in comparative perspective. The quest for control. London: Routledge.

Phadnis, U. (1980). Political dynamics of the island states: A comparative study of Sri Lanka and Maldives. Institute for Defence Studies and Analyses Journal, 12(3), 305-322.

Phadnis, U., \& Luithui, E. D. (1981). The Maldives enter world politics. Asian Affairs, 8(3), 166-179.

Phadnis, U., \& Luithui, E. D. (1985). Maldives: Winds of change in an atoll state. New Delhi: South Asian Publishers.

Pirotta, G. A. (1997). Politics and public service reform in small states: Malta. Public Administration and Development, 17(1), 197-207.

Police summon EPA chief after resignation. (2011, June 4). Haveeru Daily. Retrieved from http://www.haveeru.com.mv

Pollitt, C., \& Bouckaert, G. (2004). Public management reform. A comparative analysis (2nd ed.). Oxford: Oxford University Press.

Polterovich, V., \& Popov, V. (2007). Democratization, quality of institutions and economic growth. Transformation, Integration and Globalization Economic Research Working Paper Series No. 102. Warsaw. Retrieved from http://ssrn.com/abstract=1036841

Potter, D. (1997). Explaining democratization. In D. Potter, D. Goldblatt, M. Kiloh, \& P. Lewis (Eds.), Democratization (pp. 1-40). Milton Keynes, UK: Polity Press.

Prebble, M. (2010). With respect. Parliamentarians, officials, and judges too. Wellington, New Zealand: Institute of Policy Studies.

Premfors, R. (1998). Reshaping the democratic state: Swedish experiences in a comparative perspective. Public Administration, 76(1), 141-159. 
President's Office. (2000). Sarukaaru muwazaffunge kanthahthah hingumuge qawaaid [Government employees regulation]. Male', Maldives: President's Office.

President's Office. (2008, October 26). List of political appointees.

President's Office. (2010a, June 29). Cabinet resigns; Protests opposition MPs' "Power Grab" of executive authority. Retrieved from http://www.presidencymaldives.gov.mv/Index.aspx?lid=11\&dcid=1303

President's Office. (2010b, November 5). Parliament's refusal to endorse a cabinet minister will not remove the minister from office - the president. Retrieved from http://www.presidencymaldives.gov.mv/Index.aspx?lid=11\&dcid=1604

President's Office. (2010c, August 8). President decrees interim administrative body to ensure continuation of Supreme Court administration. Retrieved from http://www.presidencymaldives.gov.mv/Index.aspx?lid=11\&dcid=1404

President's Office. (2011, May 5). List of political appointees.

President's Office Letter. (2006, November 27). Paper on proposed amendments to civil service bill. Letter No. 1-PSD/57/2006/79.

President's Office Letter. (2008, January 22). Paper on proposed amendments to civil service act. Letter No. 1-PSD/131/2008/5.

Presidential Decree No. 2008/1. Sarukaaruge muwazaafunnaa gulhey gothun raeesuljumhooriyaage ofeehuge public service divisionun kuramun gendhaa baeh masakkath, civil service commissionaa havaalu kurumaa behey raeesul jumhooriyaage qaraar [Presidential decree on handing over some government personnel management functions undertaken by the public service division to the civil service commission].

Presidential Decree No. 2008/9. Raeesuljumhooriyaage maqaam ge vaajibu adhaa kurumah takai beynunvaa maqaam thah kan'da elhun [Determination of positions required to perform the functions of presidency].

Press Secretary warns steps will be taken against media operators. (2012, January 11). Sun. Retrieved from http://sun.mv

Przeworski, A. (1986). Some problems in the study of the transition to democracy. In G. O'Donnell, P. C. Schmitter, \& L. Whitehead (Eds.), Transition from authoritarian rule. Comparative perspectives (pp. 47-63). Baltimore, MD: The Johns Hopkins University Press.

Raadschelders, J. B. (1992). Definitions of smallness: A comparative study. In R. Baker (Ed.), Public administration in small and island states (pp. 26-33). West Hartford, CT: Kumarian Press. 
Raadschelders, J. C. N. (1998). Handbook of administrative history. New Brunswick, NJ: Transaction Publishers.

Raadschelders, J. C. N. (2003). Government. A public administrative perspective. Armonk, NY: M E Sharpe.

Raadschelders, J. C. N., \& Rutgers, M. R. (1996). The evolution of civil service systems. In H. A. G. M. Bekke, J. L. Perry, \& T. A. J. Toonen (Eds.), Civil service systems in comparative perspective (pp. 67-99). Bloomington, IN: Indiana University Press.

Rabushka, A., \& Shepsle, K. A. (1972). Politics in plural societies. A theory of democratic instability. Columbus, $\mathrm{OH}$ : Charles E Merrill.

Rajbansee, J. (1972). Size and bureaucracy in the Caribbean. Journal of Comparative Administration, 4(2), 205-224.

Randall, V., \& Svåsand, L. (2002). Introduction: The contribution of parties to democracy and democratic consolidation. Democratization, 9(3), 1-10.

Randma, T. (2001). A small civil service in transition: the case of Estonia. Public Administration and Development, 21(1), 41-51.

Rashu council hingumah dhathi kuraa kamah bune Thimarafushee zinmaadhaaru veriyaa vaki kurumah qaraareh faaskoffi [Island council passes motion accusing senior civil servant of obstruction]. (2011, June 12). Haveeru Daily. Retrieved from http://www.haveeru.com.mv

Rayyithunge Majlis. (n.d.). 15 vana rayyithunge majleehun feshigen 17 vana rayyithunge majleehuge mihaathanah majileehah hushahelhunu bill thakaai massala thakuge adhadhu [Statistics on the number of bills and cases submitted from the 15th majlis to the present time of the 17th majlis]. Retrieved from http://www.majlis.gov.mv/di/wp-content/uploads/billthakugestatistics-1.pdf

Reynolds, C. H. B. (1975). The Maldive islands. Asian Affairs, 6(1), 37-43.

Richards, D. (1997). The civil service under the conservatives 1979-97: Whitehall's political poodles? Brighton, UK: Sussex Academic Press.

Richards, D. (2003). The civil service in Britain: a case study in path dependency. In J. Halligan (Ed.), Civil service systems in Anglo-American countries (pp. 2769). Cheltenham, UK: Edward Elgar.

Richards, J. (1982). Politics in small independent communities: Conflict or consensus? Journal of Commonwealth and Comparative Politics, 20(2), 15571.

Richards, J. (1990). Micro-states: A specific form of polity? Politics, 10(1), 40-46. 
Richards, L., \& Morse, M. (2007). Readme first for a user's guide to qualitative methods (2nd ed.). Thousand Oaks, CA: SAGE Publications.

Ridley, F. F. (1983). Career service: A comparative perspective on civil service promotion. Public Administration, 61(2), 179-196.

Ridley, F. F. (1995). Civil service and democracy: questions in reforming the civil service in Eastern and Central Europe. Public Administration and Development, 15(1), 11-20.

Riggs, F. W. (1988). Bureaucratic politics in the US: Benchmarks for comparison. Governance: An International Journal of Policy and Administration, 1(4), 343-379.

Robinson, E. A. G. (1960). The size of the nation and the cost of administration. In E. A. G. Robinson (Ed.), The economic consequences of the size of nations. Proceedings of a conference held by the International Economic Association (pp. 223-240). London: Macmillan.

Rolfe, J. C. (1937). Ammianus Marcellinus with an English translation. Vol. II. Cambridge, MA: Harvard University and London: William Heinemann.

Roots, R. I. (2004). When laws backfire: Unintended consequences of public policy. American Behavioral Scientist, 47(11), 1376-1394.

Rossi, F. M., \& della Porta, D. (2009). Social movement, trade unions, and advocacy networks. In C. W. Haerpfer, P. Bernhagen, R. F. Inglehart, \& C. Welzel (Eds.), Democratization (pp. 172-185). Oxford: Oxford University Press.

Rowat, M. D. (1996). Public sector reform in the Latin American and Caribbean region - issues and contrasts. Public Administration and Development, 16(4), 397-411.

Ruddin, L. P. (2006). You can generalize stupid! Social scientists, Bent Flyvbjerg, and case study methodology. Qualitative Inquiry, 12(4), 797-812.

Rustow, D. A. (1970). Transitions to democracy: Toward a dynamic model. Comparative Politics, 2(3), 337-363.

Saeed, A. (2010, August 30). Furanee eh maqaameh, libey ujooraigai bodu farageh! [Same work but significant difference in wage!]. Haveeru Daily. Retrieved from http://www.haveeru.com.mv

Saeed, A. A. (2008, March 24). Gina adhadheh ge magistratunnaai qaal'ee aku wazeefaain vaki kurumah civil service commissionun notice fonuvumaa eku justice in iuthiraazu koffi [Ministry of Justice rejects the retirement notices sent by the civil service commission to several magistrates and a judge]. Haveeru Daily. Retrieved from http://www.haveeru.com.mv 
Saeed, A. A. (2010, June 16). Hiriyaa schoolah vahdhan ulhey teacherakaa medhu beleniverin hin hama nujehigen petitioneh hushahalhanee [Parents to submit a petition to protest the potential recruitment of a teacher to Hiriyaa school]. Haveeru Daily. Retrieved from http://www.haveeru.com.mv

Saeed, A. A. (2011, May 29). Mi dhaurugai majileehuge majority leader aai minority leader badhaluvedhaane: Majlis [The majority and minority leader of the majlis will change during this term: Majlis]. Haveeru Daily. Retrieved from http://www.haveeru.com.mv

Sahlin-Andersson, K. (2002). National, international and transnational constructions of new public management. In T. Christensen \& P. Laegreid (Eds.), New public management. The transformation of ideas and practice (pp. 43-72). Aldershot, UK, Ashgate.

Salaamathaa behey kanthah himaayath nukuranyaa media aa medhu fiyavalhu alhaanan: Defence Minister [Action will be taken against media if state security is not protected: Defence Minister]. (2011, December 26). Haveeru Daily. Retrieved from http://www.haveeru.com.mv

Salleh, S. H., \& Othman, N. (Eds.). (1992). Emerging trends of public administration in SAARC countries. Proceedings of the second South Asian conference on public administration, Islamabad, Pakistan, 18-21 September 1989. Asian and Pacific Development Centre.

Sathiendrakumar, R., \& Tisdell, C. (1989). Tourism and the economic development of the Maldives. Annals of Tourism Research, 16(2), 254-269.

Saunders, M., Lewis, P., \& Thornhill, A. (2007). Research methods for business students (4th ed.). Harlow, UK: Prentice Hall.

Saward, M. (2003). Democracy. Cambridge: Polity.

Schahczenski, J. J. (1990). Development administration in the small developing state: A review. Public Administration and Development, 10(1), 69-80.

Schedler, A., \& Sarsfield, R. (2007). Democrats with adjectives: Linking direct and indirect measures of democratic support. European Journal of Political Research, 46(5), 637-659.

Schneier, E. (2006). Crafting constitutional democracies. The politics of institutional design. Lanham, MD: Rowman \& Littlefield Publisher.

Scholte, J. A. (2001). The globalization of world politics. In J. Baylis \& S. Smith (Eds.), The globalization of world politics. An introduction to international relations (2nd ed., pp. 13-32). Oxford: Oxford University Press.

Scott, C. (2000). Accountability in the regulatory state. Journal of Law and Society, 27(1), 38-60. 
Seawright, J., \& Collier, D. (2010). Glossary. In H. E. Brady \& D. Collier (Eds.). Rethinking social inquiry: Diverse tools, shared standards (2nd ed., pp. 313359). Lanham, MD: Rowan \& Littlefield Publishers.

Selznick, P. (1957). Leadership in administration. A sociological interpretation. New York: Harper \& Row.

Service Bond for Government Funded Education Act of the Maldives. (1976), No. $29 / 76$

Shafritz, J. M. (1973). Position classification: A behavioral analysis for the public service. New York: Praeger Publishers.

Shahid, A. (2005, November 14). Civil service bill. Maldives parliamentary debates.

Shaljan, A. M. (2004). Population, gender and development in Maldives. Economic and Political Weekly, 39(18), 1835-1840.

Shand, R. T. (1980). Island smallness: some definitions and implications. In R. T. Shand (Ed.), The island states of the Pacific and Indian oceans: Anatomy of development (pp. 3-20). Canberra: The Australian National University.

Share, D., \& Mainwaring, S. (1986). Transitions through transaction: Democratization in Brazil and Spain. In W. A. Selcher (Ed.), Political liberalization in Brazil. Dynamics, dilemmas, and future prospects (pp. 175215). Boulder, CO: Westview Press.

Shareef, I. (2006, December 19). Civil service bill. Maldives parliamentary debates.

Shareef, I. (2007, April 4). Civil service bill. Maldives parliamentary debates.

Sharpe, J. (1993). The relationship between parliament and the civil service. The Parliamentarian. Journal of the Parliaments of the Commonwealth, 74(4), 218-219.

Shifleen, A. (2008, October 26). Dr. Raazee director general kamuge maqaamum deputy director general ge maqaamah dhahkoffi [Dr.Razee demoted from the post of director general to deputy director general]. Haveeru Daily. Retrieved from http://www.haveeru.com.mv

Shils, E. A. (1959). Resentments and hostilities of legislators: Sources, objects, consequences. In J. C. Wahlke \& H. Eulau (Eds.), Legislative behavior. A reader in theory and research (pp. 347-354). Illinois: The Free Press of Glencoe.

Silverman, D. (2005). Doing qualitative research. A practical handbook (2nd ed.). London: SAGE Publications.

Simons, H. (2009). Case study research in practice. London: SAGE Publications. 
Slife, B. D., \& Williams, R. N. (1995). What's behind the research? Discovering hidden assumptions in the behavioral sciences. Thousand Oaks, CA: SAGE Publications.

Srebrnik, H. (2004). Small island nations and democratic values. World Development, 32(2), 329-341.

Stahl, O. G. (1962). Public personnel management (5th ed.). New York: Harper and Row.

Stake, R. E. (1995). The art of case study research. Thousand Oaks, CA: SAGE Publications.

Stake, R. E. (2000). The case study method in social inquiry. In R. Gomm, M. Hammersley, \& P. Foster (Eds.), Case study method. Key issues, key texts (pp. 19-26). London: SAGE Publications.

Starling, G. (1993). Managing the public sector (4th ed.). Belmont, CA: Wadsworth Publishing Company.

Stepan, A. (1986). Paths toward redemocratization: Theoretical and comparative considerations. In G. O’Donnell, P. C. Schmitter, \& L. Whitehead (Eds.), Transition from authoritarian rule. Comparative perspectives (pp. 64-84). Baltimore, MD: The Johns Hopkins University Press.

Stepan, A., \& Skach, C. (1993). Constitutional frameworks and democratic consolidation: Parliamentarianism versus presidentialism. World Politics, $46(1), 1-22$.

Suleiman, E. (2003). Dismantling democratic states. Princeton, NJ: Princeton University Press.

Suryanarayan, V. (1998). Islam, political evolution and national identity in Maldives. In N. N. Vohra \& J. N. Dixit (Eds.), Religion, politics and society in South and Southeast Asia (pp. 113-27). New Delhi: Konark Publishers.

Suryanarayan, V. (2009). Democracy in Maldives. In N. K. Jha (Ed.), Democracy, nation building and peace in South Asia. Challenges and prospects (pp. 191197). New Delhi: Har-Anand Publications.

Sutton, P. (1987). Political aspects. In C. Clarke \& T. Payne (Eds.), Politics, security and development in small states (pp. 3-25). London: Allen \& Unwin.

Sørensen, G. (1998). Democracy and democratization. Processes and prospects in a changing world (2nd ed.). Boulder, CO: Westview Press.

Sørensen, G. (2010). Democracy and democratization. In K. T. Leicht \& J. C. Jenkins (Eds.), Handbook of politics. State and society in global perspective (pp. 441-458). New York: Springer. 
Taylor, S. J., \& Bogdan, R. (1998). Introduction to qualitative research methods. A guidebook and resource (3rd ed.). New York: John Wiley \& Sons.

Teichmann, I. (2002). Globalisation. London: Franklin Watts.

The Committee of Minister of Council of Europe. (2000). Recommendation of the committee of ministers to member states on the status of public officials in Europe, adopted by the committee of ministers on 24 February 2000 at the $699^{\text {th }}$ meeting of the Ministers' Deputies. No. R(2000)6, Strasbourg, France. Retrieved from https://wcd.coe.int/ViewDoc.jsp?id=340693\&Site=CM\&BackColorInternet= C3C3C3\&BackColorIntranet=EDB021\&BackColorLogged=F5D383

The National Democratic Institute for International Affairs. (2004). Assessment of the opportunities and the challenges to the development of political parties in the Maldives. Retrieved from http://www.mv.undp.org/v2/publication_files/4b35f8cdb59cc.pdf

Thinadhoo katheebu ge eheetheriyaa geygai madu kuran councilun angaifi [Thinadhoo council suspends civil servant]. (2011, July 12). Haveeru Daily. Retrieved from http://www.haveeru.com.mv

Thomas, G. (2011a). A typology for the case study in social science following a review of definition, discourse, and structure. Qualitative Inquiry, 17(6), 511521.

Thomas, G. (2011b). The case: generalisation, theory and phronesis in case study. Oxford Review of Education, 37(1), 21-35.

Thompson, J. R. (2006). The federal civil service: The demise of an institution. Public Administration Review, July / August, 496-503.

Threatening the media is not acceptable in a civilised society: Media Council. (2012, January 15). Sun. Retrieved from http://sun.mv

Tomlin. (1931). Report of the royal commission on the civil service, 1929-31. Cmd 3909. London: HMSO.

Transparency International. (2011). Daily lives and corruption: Public opinion in South Asia. Transparency International.

Trendafilova, T. (2008). Managing the civil service. Roles, mechanisms and capacities - Central capacity and line ministries. Paper presented on the workshop 'Building a Professional Civil Service in Kosovo', co-organised by SIGMA and the Ministry of Public Services of Kosovo, Prishtina, Kosovo. Retrieved from http://www.oecd.org/dataoecd/35/49/40975348.pdf

Turner, M., Chuki, S., \& Tshering, J. (2011). Democratization by decree: the case of Bhutan. Democratization, 18(1), 184-210. 
United Nations Development Programme. (n.d.). Democratic governance - Fast fact. Retrieved from http://www.mv.undp.org/v2/downloads/4d946d2ae4b84_UNDP\%20Factshee t\%20-\%20Governance\%202011.pdf

United Nations Development Programme Maldives. (2011). Summary report. Comprehensive study of the Maldivian civil society. Male', Maldives: UNDP Maldives.

United Nations Institute for Training and Research. (1969). Status and problems of very small states and territories. New York: United Nations.

Van der Meer, F. M., Steen, T., \& Wille, A. (2007). Western European civil service systems: A comparative analysis. In J. C. N. Raadschelders, T. A. J. Toonen, \& F. M. Van der Meer (Eds.), The civil service in the $21^{\text {st }}$ century. Comparative perspectives (pp. 34-49). Basingstoke, UK: Palgrave Macmillian.

Vaughn, R. G. (1976). Principles of civil service law. New York: Matthew Bender.

Verba, S. (1965). Comparative political culture. In L. W. Pye \& S. Verba (Eds.), Political culture and political development (pp. 512-560). Princeton, NJ: Princeton University Press.

Verheijen, T. (2000). Administrative capacity development: A race against time? Working Documents No. 107. The Hague: Scientific Council for Government Policy.

Video footage shows MDP activists intimidating CSC. (2010, February 4). Haveeru Daily. Retrieved from http://www.haveeru.com.mv

Vital, D. (1967). The inequality of states: A study of the small power in international relations. Oxford: Clarendon Press.

Voltmer, K., \& Rawnsley, G. (2009). The media. In C. W. Haerpfer, P. Bernhagen, R. F. Inglehart, \& C. Welzel (Eds.), Democratization (pp. 234-248). Oxford: Oxford University Press.

Waheed, A. (2011, November 22). Civil service amendment bill. Maldives parliamentary debates.

Weber, M. (2007). Bureaucracy. In J. M. Shafritz \& A. C. Hyde (Eds.), Classics of public administration (pp. 43-48). Boston, MA: Thomson Wadsworth.

Welzel, C. (2009). Theories of democratization. In C. W. Haerpfer, P. Bernhagen, R. F. Inglehart, \& C. Welzel (Eds.), Democratization (pp. 74-90). Oxford: Oxford University Press.

Welzel, C., \& Inglehart, R. (2006). The human development model of democracy: East Asia in perspective. In R. J. Dalton \& D. C. Shin (Eds.), Citizens, 
democracy and markets around the Pacific rim (pp. 21-49). Oxford: Oxford University Press.

Welzel, C., \& Inglehart, R. (2008). The role of ordinary people in democratization. Journal of Democracy, 19(1), 126-140.

Welzel, C., \& Inglehart, R. (2009). Political culture, mass beliefs, and value change. In C. W. Haerpfer, P. Bernhagen, R. F. Inglehart, \& C. Welzel (Eds.), Democratization (pp. 126-144). Oxford: Oxford University Press.

Wettenhall, R. (1992). Small states: Some machinery-of-government considerations. In R. Baker (Ed.), Public administration in small and island states (pp. 4968). West Hartford, CT: Kumarian Press.

Whitehead, A. (1997). The Maldives. The Round Table, 86(341), 51-52.

Whitehead, L. (1986). International aspects of democratization. In G. O'Donnell, P. C. Schmitter, \& L. Whitehead (Eds.), Transitions from authoritarian rule. Comparative perspectives (pp. 3-46). Baltimore, MD: The Johns Hopkins University Press.

Wood, B. D., \& Waterman, R. W. (1994). Bureaucratic dynamics - The role of bureaucracy in a democracy. Boulder, CO: Westview Press.

World Bank. (1980). The Maldives. An introductory economic report (Report No. PUB2739). Retrieved from http://wwwwds.worldbank.org/external/default/WDSContentServer/WDSP/IB/2005/10/14 /000178830 98101903335821/Rendered/PDF/PUB2739000Mald0my000an0i ntroduction.pdf

World Bank. (1984). The Maldives: An update economic memorandum (Report No. 4881-MAL). Retrieved from http://wwwwds.worldbank.org/external/default/WDSContentServer/WDSP/IB/1984/01/01 /000009265_3980203114718/Rendered/PDF/multi0page.pdf

World Bank. (1996). Implementation completion report. Republic of Maldives education and training project (Report No. 15759). Retrieved from http://wwwwds.worldbank.org/external/default/WDSContentServer/WDSP/IB/1996/06/ 18/000009265_3961019223932/Rendered/PDF/multi_page.pdf

World Bank. (2001). Implementation completion report on a credit in the amount of SDR 9.3 million (US\$13.4 million equivalent) to the Republic of Maldives for a second education and training project (Report No. 21916). Retrieved from http://www-

wds.worldbank.org/external/default/WDSContentServer/WDSP/IB/2001/06/ 23/000094946_01060804031587/Rendered/PDF/multi0page.pdf

World Bank. (2005). Economic growth in the 1990s. New York: Oxford University Press. 
World Bank. (2007). Implementation completion and results report on a credit in the amount of SDR 12.9 million (US\$17.6 million equivalent) to the Republic of Maldives for a third education and training project (Report No. ICR0000521). Retrieved from http://wwwwds.worldbank.org/external/default/WDSContentServer/WDSP/IB/2007/08/ 29/000020953_20070829134408/Rendered/PDF/ICR0000521.pdf

World Bank. (2012). World development indicators. Retrieved on February 6, 2012, from http://data.worldbank.org/indicator/DT.ODA.ODAT.GN.ZS/countries?displa $\mathrm{y}=$ default

World Health Organization. (2008). Country cooperation strategy at a glance. Retrieved from http://www.who.int/countryfocus/cooperation_strategy/ccsbrief_mdv_en.pdf

World Health Organization. (2010). Maldives health profile. Retrieved from http://www.who.int/gho/countries/mdv.pdf

Yilmaz, H. (2009). The international context. In C. W. Haerpfer, P. Bernhagen, R. F. Inglehart, \& C. Welzel (Eds.), Democratization (pp. 92-106). Oxford: Oxford University Press.

Yoosuf, A. (2004, September 1). Dhivehi fuluhunge khidmathuge aa safhaa eh [A new page for the Maldivian police]. Haveeru Daily. Retrieved from http://www.haveeru.com.mv

Young, Lieut. I. A., \& Christopher, W. (1844). Memoirs on the inhabitants of the Maldive islands. Transactions of the Bombay Geographical Society, I, 54108.

Zaki, I. H., \& Parakh, R. M. (2008). Small states security dilemma. A Maldivian perception. New Delhi: Lancers’ Book.

Zameer, A. (1994). Public administration in the Maldives: issues and prospects for the twentieth century. South Asian Journal of Management, January-March, 24-33.

Zolo, D. (2007). Globalisation. An overview. Colchester, UK: European Consortium for Political Research.

Zuckerman, A. (1977). The concept "Political Elite": Lessons from Mosca and Pareto. The Journal of Politics, 39(2), 324-344. 


\section{Annex 1: Information sheet}

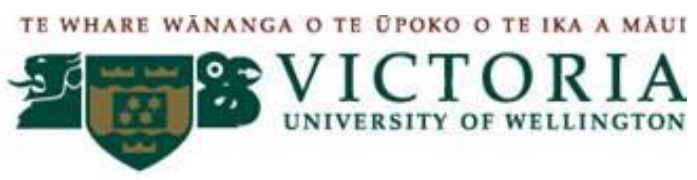

\section{SCHOOL OF GOVERNMENT}

$7^{\text {th }}$ April 2010

\section{INFORMATION SHEET}

Project Title: Civil service in an emerging democracy - The case of the Maldives

Researcher: Mohamed Faizal, School of Government, Victoria University of Wellington, New Zealand

I am a PhD Student in Public Policy, at the Victoria University of Wellington, New Zealand. My thesis is focused on analysing civil service in an emerging democracy, with a focus on the Maldives. I intend to describe the civil service model of the Maldives and analyse the process by which the political actors arrived at the current model during the transition to a multi-party democracy. Furthermore, the study aims to study the impact the civil service has on the democratisation process and will consider what light the Maldives experience can shed on the role of a civil service in the context of a small-island state. The University has agreed on my areas of study and granted ethics approval to carry out the research.

The practical details for the interview are covered in the consent form. The interview will be conducted based on the preferences that you choose in the consent form. They include your choice of language to be used during interviewing and your consent on tape-recording the interview. The interview will last for a maximum of 2 hours. It is very important to point out that the participation in this research is voluntary and based on the participants' willingness. Participants have the right to withdraw from the research within one month of the completion of the interview.

The information gathered from the interviews will be the prime source of data. Names of individuals will not appear in the analysis, the thesis or any articles. While it is not possible to guarantee absolute anonymity, I will endeavour to the best of my ability to ensure that, if you are quoted directly, you are not identifiable from the way I use your words in the text. The consent forms, hand notes, tape recordings or any other material collected in connection with the interview that may reveal your identity will be kept confidential to me. If information about the interviews is supplied to my supervisors or other researchers (that is 
researchers involved in verification of journal articles and conference papers) it will be in a form that will not directly or indirectly disclose your identity. The thesis will be submitted to the School of Government and it will be deposited in the University Library. The information gathered will also be used for one or more articles that will be submitted for publication in international journals. Such articles may be presented in academic or professional conferences. The information gathered will be destroyed 3 years after the full completion of my doctoral degree.

If you have any questions or would like additional information regarding my research, please contact my principal supervisor, Rob Laking, Institute of Policy Studies at Victoria University of Wellington, P.O. Box 600, Wellington, or email: rob.laking@ vuw.ac.nz

Your sincere responses during the interview will be appreciated.

Mohamed Faizal

Signed:

School of Government

Victoria University of Wellington

P.O. Box 600

Wellington, New Zealand

Email: mohamed.faizal@vuw.ac.nz

Phone: 


\title{
Annex 2: Consent to participation in research
}

\author{
TE WHARE WANANGA O TE OPOKO O TE IKA A MAUT

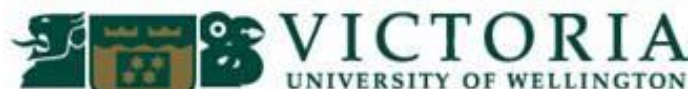 \\ SCHOOL OF GOVERNMENT

\section{CONSENT TO PARTICIPATION IN RESEARCH}

\section{Project Title: Civil service in an emerging democracy - the case of the Maldives}

I have been provided with adequate information relating to the nature and objectives of this research project and I have understood that information. I have been given the opportunity to seek further clarification or explanations regarding the research and they have been answered to my satisfaction. I understand that I may withdraw from this study within one month of this interview without giving any reason, and in such cases all data related to me shall be destroyed.

I understand that my personal identity will be kept confidential to the researcher and that information from this interview will not be made available to any other person in a form which would identify me. I also understand that the published results will not use my name, and that no opinion will be attributed to me in any way. I understand that the electronic recordings and all documents related to this interview will be destroyed 3 years after the conclusion of the project. I understand that the data I provide will not be used for any purpose other than the uses mentioned in the Information Sheet provided to me, and any further use will require my written consent.

I understand that the maximum length of the interview will be 2 hours.

(Please mark a $\checkmark$ to indicate agreement)

I agree to take part in this research.

I I would prefer to conduct the interview in Dhivehi language.

I would prefer to conduct the interview in English language.

I I am indifferent on using Dhivehi or English language for the interview (In this case English will be used)

I agree for this interview to be tape-recorded.

- I agree on direct quotations from the interview to be used in the research (While it is not possible to guarantee absolute anonymity, I will endeavour to the best of my ability to 
ensure that, if you are quoted directly, you are not identifiable from the way I use your words in the text)

I would like to receive a written draft of this interview.

I I understand that I may withdraw from this study within 1 month of this interview.

Signature:

Name:

Date:

Preferred date for interview:

Preferred time for interview:

Preferred venue for interview (please choose a secure \& quite place):

THANK YOU 
Annex 3: List of interviewees

\begin{tabular}{|c|c|c|}
\hline Code & Category & Date of Interview \\
\hline CV1 & Civil society & June 2, 2010, Wednesday \\
\hline FO1 & Former senior government official & May 16,2010, Sunday \\
\hline FO2 & Former senior government official & May 20, 2010, Thursday \\
\hline FO3 & Former senior government official & May 31, 2010, Monday \\
\hline FO4 & Former senior government official & June 3, 2010, Thursday \\
\hline FO5 & Former senior government official & June 12, 2010, Saturday \\
\hline FO6 & Former senior government official & June 15,2010 , Tuesday \\
\hline FO7 & Former senior government official & June 15, 2010, Tuesday \\
\hline FO8 & Former senior government official & June 25,2010, Friday \\
\hline FO9 & Former senior government official & July 5, 2010, Monday \\
\hline FO10 & Former senior government official & July 14, 2010, Wednesday \\
\hline FO11 & Former senior government official & August 10, 2010, Tuesday \\
\hline GO1 & Senior government official & May 23, 2010, Sunday \\
\hline GO2 & Senior government official & May 30, 2010, Sunday \\
\hline GO3 & Senior government official & June 28, 2010, Monday \\
\hline GO4 & Senior government official & June 30, 2010, Wednesday \\
\hline GO5 & Senior government official & $\begin{array}{l}\text { August } 8,2010, \text { Sunday } \& \\
\text { August } 16,2010, \text { Monday }\end{array}$ \\
\hline GO6 & Senior government official & $\begin{array}{l}\text { September } 8,2010, \\
\text { Wednesday }\end{array}$ \\
\hline GO7 & Senior government official & October 4, 2010, Monday \\
\hline MD1 & Media personnel & July 22, 2010, Thursday \\
\hline PL1 & Senior government political figure & June 14, 2010, Monday \\
\hline PL2 & Senior government political figure & July 6, 2010, Tuesday \\
\hline \multicolumn{3}{|c|}{$\begin{array}{l}\text { Note: Government political figures mean political appointees of the government that lasted from } \\
\text { November } 11,2008 \text { to February } 7,2012 \text {. Former senior government officials mean officials of the } \\
\text { government prior to November } 11,2008 \text {. Senior government officials include senior civil servants } \\
\text { and commissioners of statutory organisations. }\end{array}$} \\
\hline
\end{tabular}




\section{Annex 4: Timeline of important events}

1153 A.D. $\quad$ Converted to Islam

1887 A.D. $\quad$ Signed a protectorate agreement with Britain

December $1932 \quad$ First written constitution proclaimed

January $1953 \quad$ Start of the First Republic

March $1954 \quad$ Monarchy reinstated

July 1965 Gained political independence from Britain

November 1968 Start of the Second Republic

November $1978 \quad$ Gayoom elected as president

November $1982 \quad$ NOPAR established

January $1998 \quad$ A revised constitution came into effect

September $1999 \quad$ PSD established

September 2003 Civil unrest in Male’

June 2004 Democratic reform policy announced

July $2004 \quad$ Constitutional assembly convened

August $2004 \quad$ Civil unrest in Male’

June $2005 \quad$ Formation of political parties allowed

October 2005 A civil service bill submitted

May 2007 Civil service bill became law

August $2007 \quad$ Referendum on form of government

May 2008 Civil service formally established

August $2008 \quad$ New constitution came into effect

November $2008 \quad$ Nasheed elected as president

February 2012 Resignation of President Nasheed 


\section{Annex 5: Government organisation chart - July 1979}

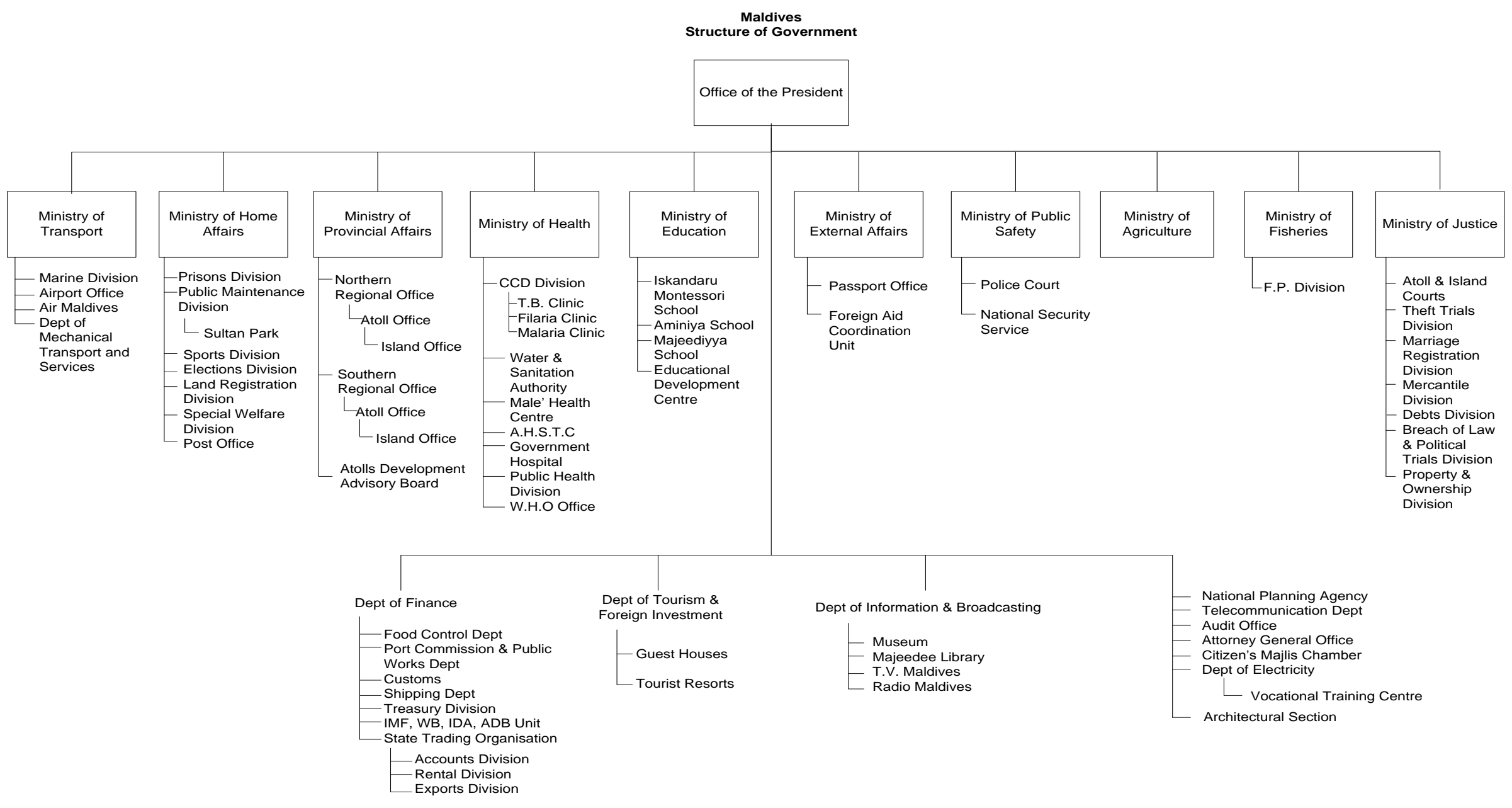

